Vol. 8. No.1, May, 2019 ISSN: 2090-5890

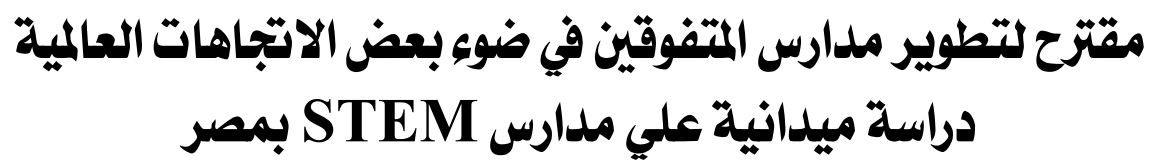

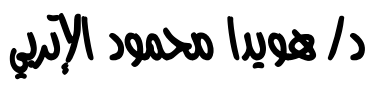

أستاذ أصول التربية المساعد -كلية التربية جامعة طنطا

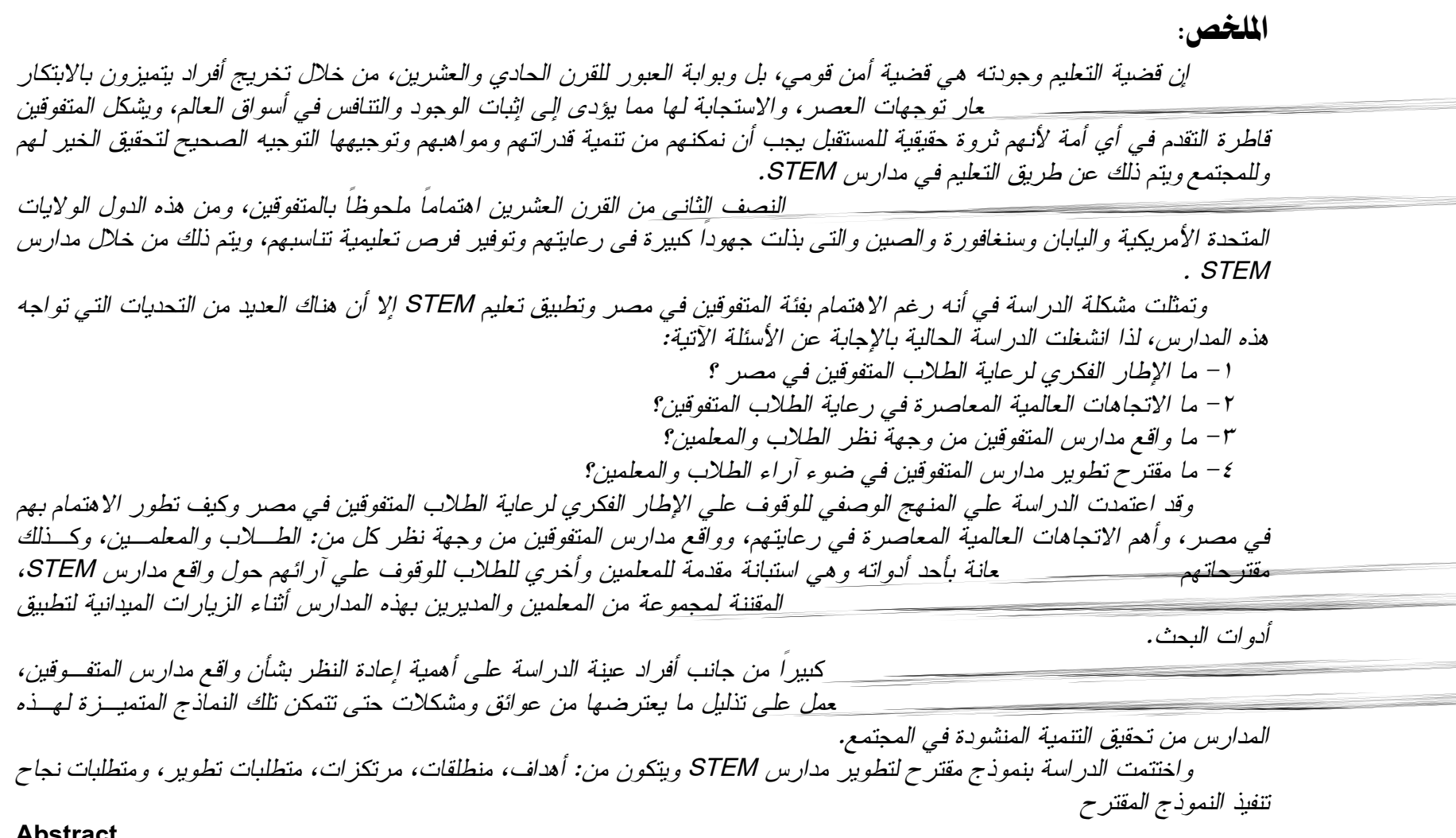

The issue of education and quality is a matter of national security and the gateway to the twenty-first century through the graduation of individuals characterized by innovation, creativity, excellence, sophistication, sensing and responding to the trends of the age, leading to proof of existence and competition in world markets. A true future must enable them to develop their abilities and talents and direct them to the right direction for their good and for the community and this is done by teaching in STEM schools.

Most of the developed and developing countries in the second half of the 20th century have paid great attention to the outstanding ones, including the United States of America, Japan, Singapore and China, who have made great efforts to nurture them and provide them with educational opportunities through the STEM schools.

The problem of the study was that despite the interest in the category of outstanding students in Egypt and the application of STEM education, there are many challenges facing these schools. Therefore, the present study was concerned with answering the following questions:

1-What is the intellectual framework for the care of outstanding students in Egypt?

2- What are contemporary global trends in caring for outstanding students?

3-What is the reality of the schools of excellence from the perspective of students and teachers? 4-What is the proposal to develop schools of excellence in light of the views of students and teachers? 
The study was based on the descriptive approach to identify the intellectual framework for caring for outstanding students in Egypt and how they developed their interest in Egypt, the most important contemporary world trends in their care, and the reality of the outstanding schools from the point of view of students and teachers as well as their suggestions for developing them. A questionnaire for teachers and others for students to take their views on the reality of the STEM schools, their proposals for their development, and the unofficial interview of a group of teachers and principals at these schools during field visits to implement research tools.

The results of the study revealed that there is a great agreement by the members of the study sample on the importance of reconsidering the reality of the schools of excellence, the needs of both students and teachers and the importance of working to overcome obstacles and problems so that these distinctive models of these schools can achieve the desired development in society.

The study concluded with a proposed model for the development of STEM schools and consists of: objectives, starting points, foundations, development requirements, requirements for successful implementation of the proposed model

مقدمة - - مقة

لتحقيق الخير لهم وللمجتمع ويـتم ذلــــــــن طريق التعليم في مدارس STEM ، إلا أن هذا

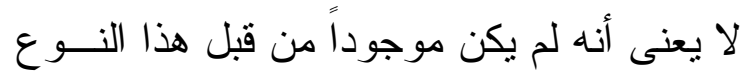

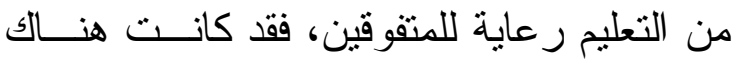
أنظمة متعددة لرعاييتهم في هذا المجال ولكنها لم تكن بالكفاءة الحالية، ومن هــــه الأنظمــة:

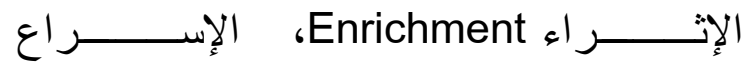
Grouping Acceleration و التجميع. وقد اهتمت معظم الدول المتقدمة و النامية فى النصف الثانى من القرن العشرين اهتمامــاً ملحوظاً بهم، ومن هذه الدول الولايات المتحدة

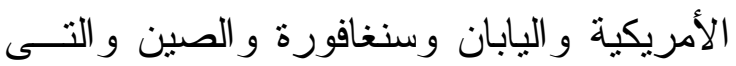

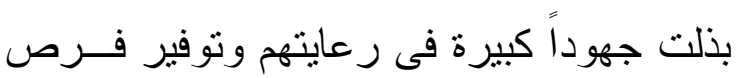

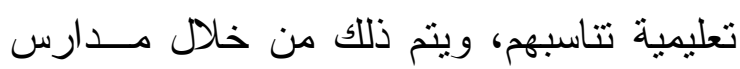

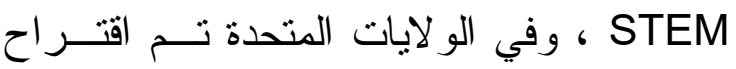
العديد من الأنظمة و الاستر اتيجيات مــن أجــل التحل

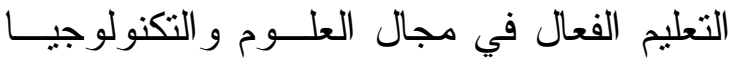

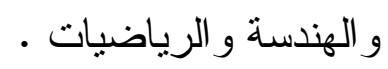

وقد ناقتشت العديد من الدراسات فعاليـــة ومواطن القصور التي نواجهها في تعليم العلوم
يقاس تقدم الأمم بما لايها مــن مـــوارد

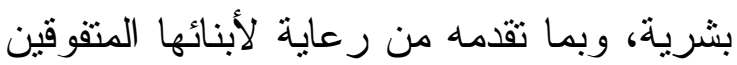

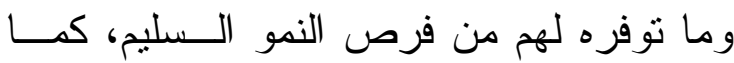

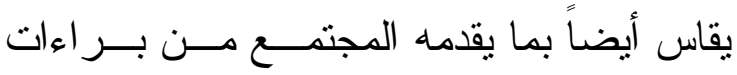

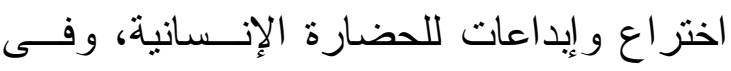
مصر إذا أردنا أن يكون لنا مكانًا اســتر اتيجيًا

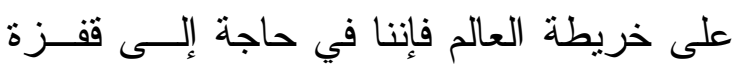

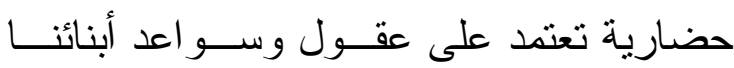

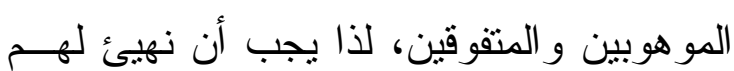
الظروف التي تساعدهم على اكتشاف ما لــديهم

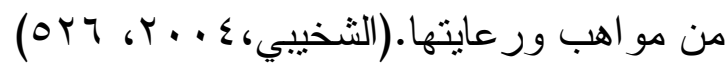
إن قضية التعليم وجودته هي قضية أمن

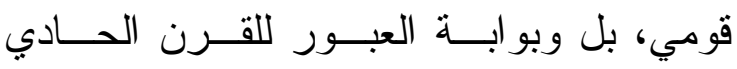

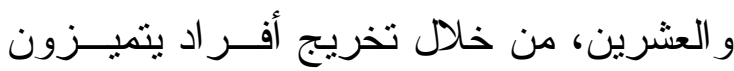
بالابتكار و الإبداع و التميز و التجويد و استـشعار توجهات العصر ، و الاستجابة لها مما يؤدى إلى ولى ولئين

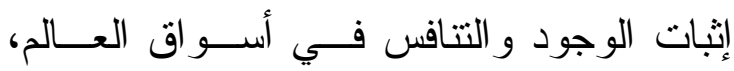

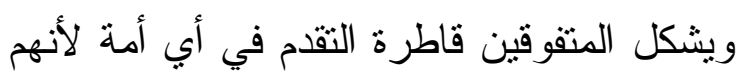
ثروة حقيقية للمستقبل يجب أن نمكنهم من نتمية قدر اتهم ومو اهبهم وتوجيهـا التوجيه الـصحيح 
دفعت هذه العو امل العلماء إلــى الــدعوة إلـى

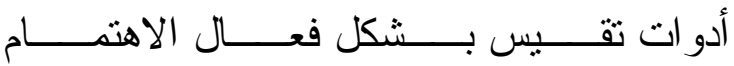

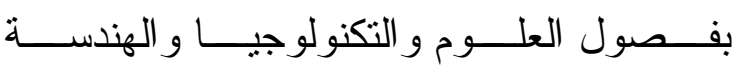

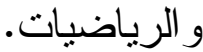

ويعد توفير بيئة تعليمية مناسـبة لتتميــة

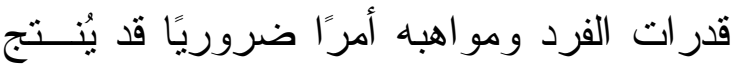
مختر عين، قادة، مفكرين، وعباقرة قادرين على تغيير موازين الكون، بالاستفادة من القـدرات

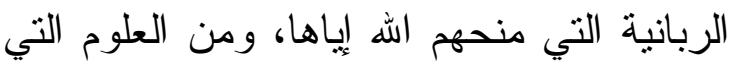
تمت در استها من خلال هذه البيئة.

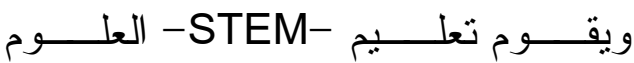
و التكنولوجيا و الهندسة و الرياضيات علي إنشاء مجتمع يركز على الابتكار ويلم بمهار ات القرن الحادي و العشرين ، ولدية القدرة على إجــر اء بحوث متقدمة على تكامل مهار ات تعليم العلوم و التكنولوجيا و الهندسة المتتو عة. وفي مــصر أصـــرت وزارة التربيــة

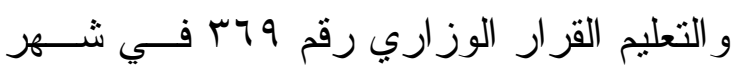

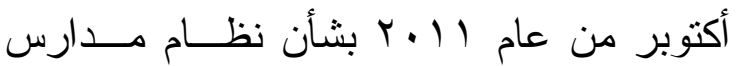
المتفوقين للثانوية العامة في العلوم و التكنولوجيا حيث تهدف إلي رعاية المو هوبين و المتهــوقين و الاهتمام بقدر اتهم وتدريس المناهج المتطــــورة

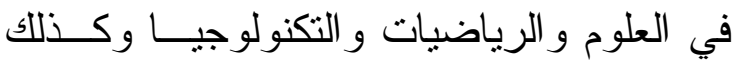
تطوير استخدام أساليب تكنولوجيا المعلومسـات لتطوير العملية التعليمية وترسيخ القيم الروحية

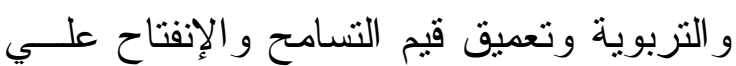
العالم وفتح المجال أمام القدرة الكامنة الإبداعية

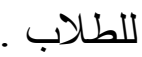

و التكنولوجيا و الهندسة و الرياضيات ، كمــــا أن

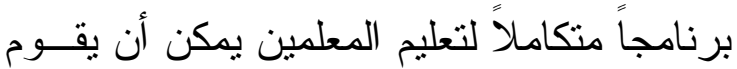

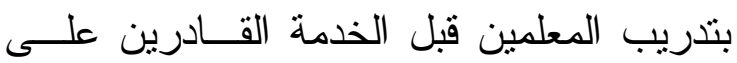
تتفيذ تعليم STEM بحيث يمكنه زيادة قدر ات (Sumen \& Calisici, . الطلاب على الابتكار

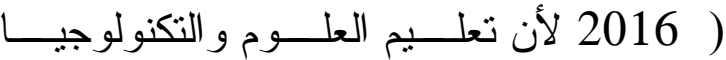
و الهندسة هو نهج تعليمي يركز على الابتكـــار، النطوير التكنولوجي، ويسهم في تتمية مهارات القرن الحادي و العشرين. وقد سعت الدول المتقدمة إلي الاهتمــام بتعليم STEM وعلي سبيل المثال " تم إطلاق الهن العديد من المبادرات لتوليد المزيد من الاهتمام

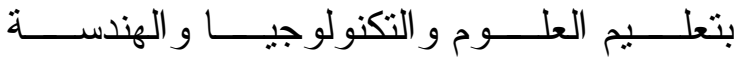
و الرياضــــــــــات STEM

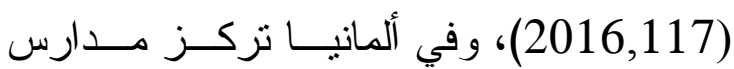
Magnet الثانوية عالية الأداء علـى العلــوم و التكنولوجيا و الهندسة و الرياضيات (STEM)

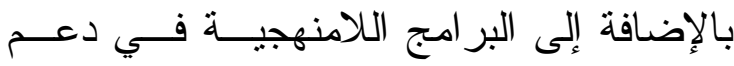
STEM للطلاب الموهوبين وتساعد على زيادة

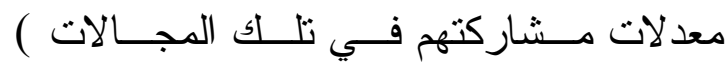
.Stoeger, et al, 2017, 399) كما أكدت دراسة (Kier, et al, 2014)

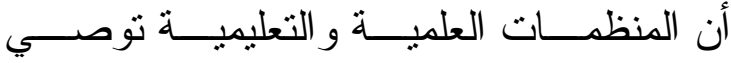
بأن تبدأ الجهود المبذولة لإثارة اهتمام الطلاب

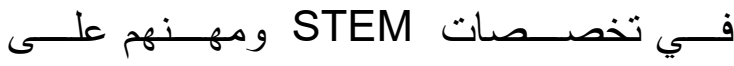
مستوى المدارس المتوسطة، وهو الوقت الـــي

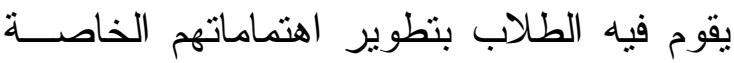

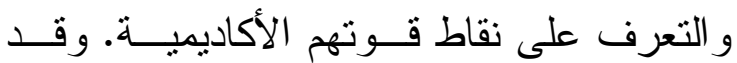


العلميــة وســـــلو ا بالأقــــام الأدبيــة. )

Eramsus, 2016, 16)

- تعاني المدارس مـن الــنقص فـى عـد الإخصائيين و المرشدين المهنيين و النفسيين و المرشدين الأكاديميين اللازمين لرعايــة الطلاب الموهوبين وفي حالة توفرهم فإنهم غير مؤهلين للعمل بهذه المدارس

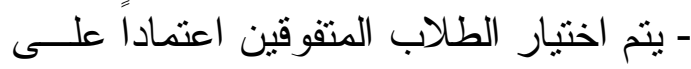
القدرة التحصيلية في الأساس مع إهمال باقي الطي اعني القدرات، حيث اثشترطت المادة الثانية مسن الهـن

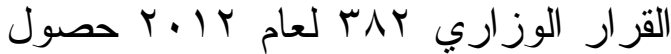
الطالب علي 91\% من المجمــوع الكالـي الـي للارجات، كما يكون حاصئًا علي الدرجات

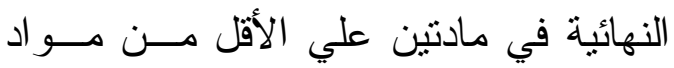
اللغة الانجليزبة، العلوم، الرياضيات. - يعتبر المعلمون الطلاب المتقوفين خارجون عن النظام المدرسـي، ويحتــاجون إلـى التوجيه المستمر حتى تكون لايهم أســاليب

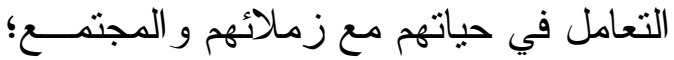

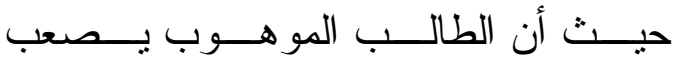

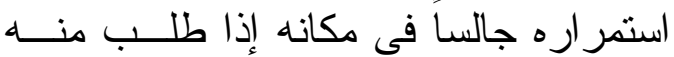

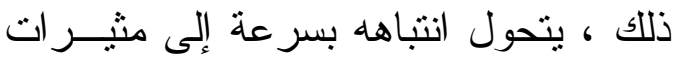
خارجية، يشعر بالقلق و الصعوبة فى اتبـــاع

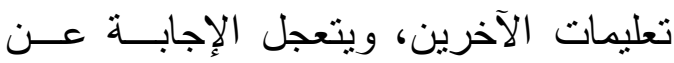

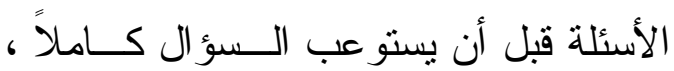

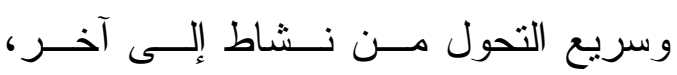
و السخرية من الآخرين و أعمالهم.

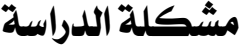

وتتمتل مشكلة الدراسة في أنسـهـ رغـــ

الاهتمام بفئة المتفوقين فـي مـــر وتطبيــق

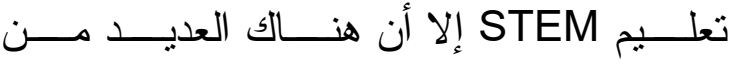

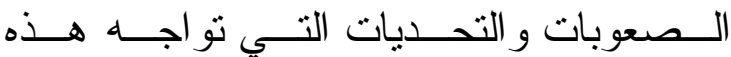

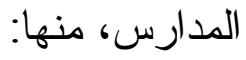

- رغم إتقان الطلاب المنهج الدراسـي ، إلا أن شرحه تم بطرق تقليدية. ـ تميز الطلاب بمهار ات القراءة و الكتابة الرئيسة ، ولكن مهارات STEM مثل فهير التصميم و الاستقسار و الابتكار و العمل في

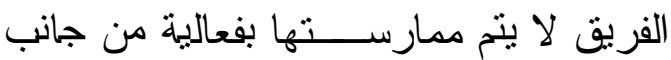

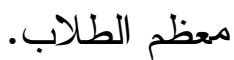
- تم توظيف هيئة تدريس متتوعة بمـــارس

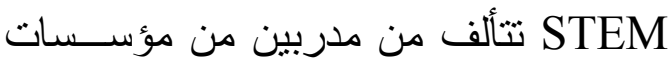

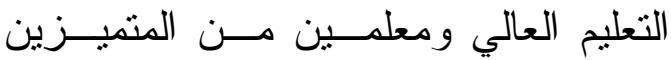

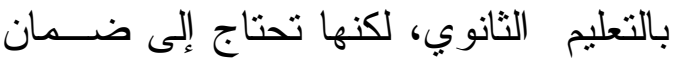
التطوير المهني المنتظم الذي يركز علـى التى خبرات التدريب و التطوير الثامل لوحدات تعليمية متعددة التخصصات. ـ أدو ات التقييم المستخدمة ليست مناسبة للبيئة

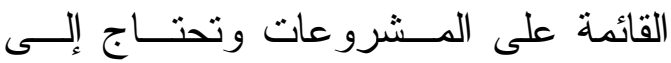
الاستعاضة عنها بتلك المستخدمة مع نهــــ (Abd El في جميع أنحاء العالم. STEM Aziz, 2014)

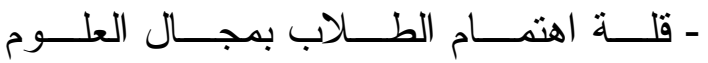

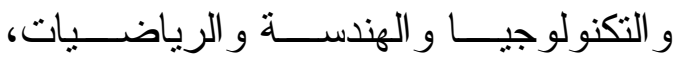
و أنثارت إحدي الدر اسات إلي ترك مــائتين

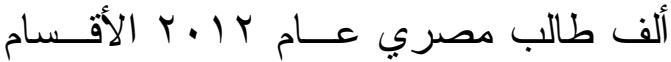




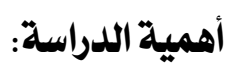

تمثلـــت أهميــة الدر اســـة فــي أهميــة

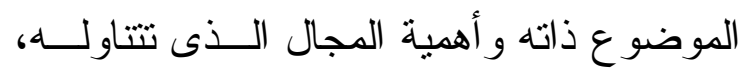
فالمتفوقون هم ثروة مصر الحقيقيــة، ويتعــين

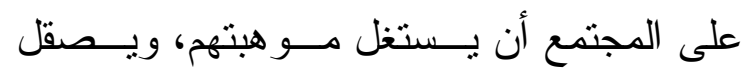
قدر اتهم، لذا تكمن أهمية الدر اسة في: الهئ

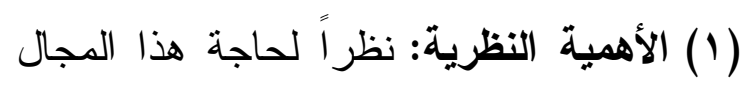

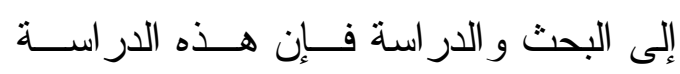

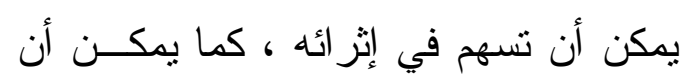

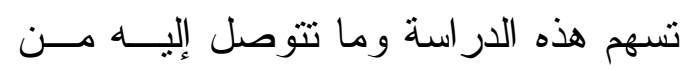

$$
\text { نتائج وتوصيات في: }
$$

- لفت نظر المسئولين بوزارة التربية و التعليم

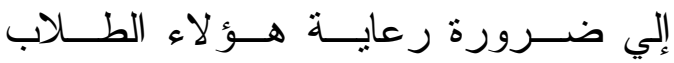
المتفوقين فإذا لم تتو افر لهم الرعاية الكافية التى توجهرم التوجيه الصحيح لتحقيق الخير

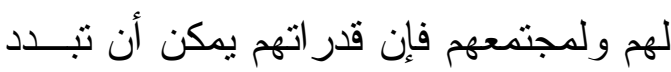

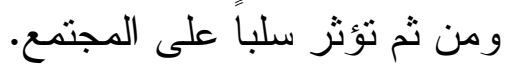

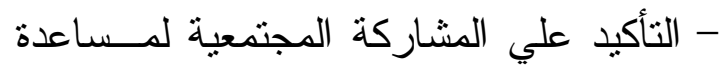

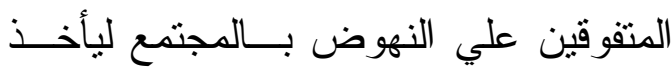

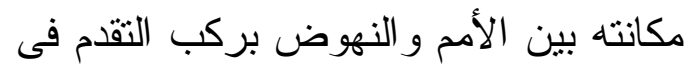

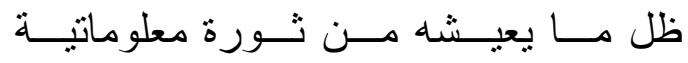
وتكنولوجية وما ينرتب علـي ذلــك مسن توجهات فكرية.

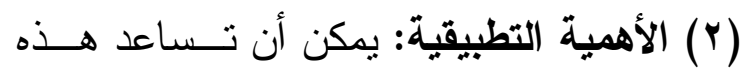
الدر اسة وما تتوصل إليه من نتائج فى:

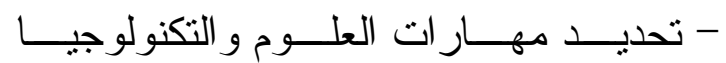
و الهندسة و الرياضيات، ومعايير الممارســة في تعليم STEM عن طريق تحديد مــزيج

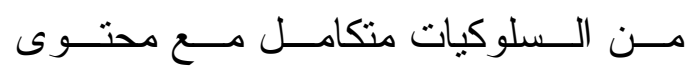

- ضعف اهتمام الطلاب المتفوفين بالحصول على الدرجات العالية في تحصيلهم و انعدام رغبتهم في تكملة دراستهم، لعـدم تــوفر

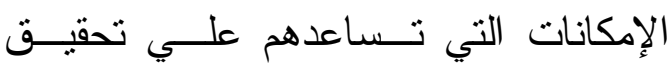
أفكار هم و إيداعاتهم.

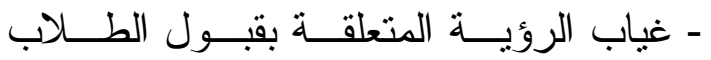
بالجامعة و التتسيق و الــدرجات الاعتباريسـة لهم.

وفى ضوء ما سبق تحاول الاراســـة الحاليــة الإجابة عن الأسئلة البحثية التالية:

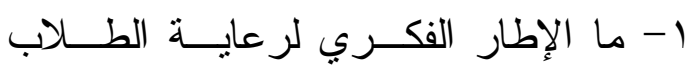
المتفوقين في مصر ؟ الاطنا

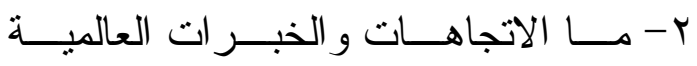
المعاصرة في رعاية الطلاب المتفوقين؟ ب- ما و اقع مدارس المتفوقين مــن وجهـــة نظر الطلاب و المعلمين؟ ع - ما مقتر ح تطوير مدارس المنقوقين فـــي

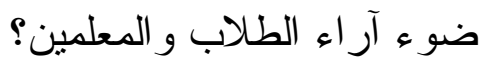

أهداف الدراسة: تتمثل أهداف الدراسة في: 1-وضع إطار فكــري لرعايــة الطــلاب المتفوقين في مصر. r- عرض الاتجاهات و الخبـــرات العالميــــة المعاصرة في رعاية المتفوقين. r- التعرف إلى و اقع مدارس المتقوقين من عن وجهة نظر المعلمين و الطلاب. ـ - وضع مقتر ح لتطوير مدارس المتفــوقين في ضوء آر اء الطلاب و المعلمين. V 
المتفوقين من وجهة نظر كــلـ مــن: الطــلاب

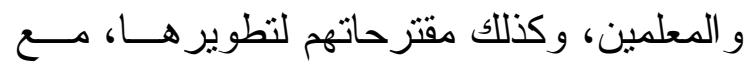

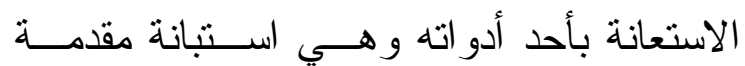

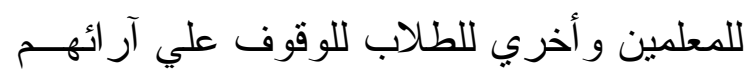

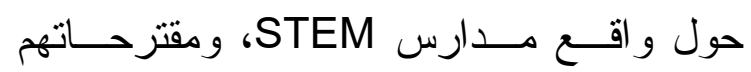
لتطوير ها، هذا بالإضافة إلــي المقابلـــة غيــر

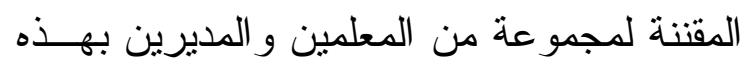
المدارس أثناء الزيارات الميدانية لتطبيق أدوات

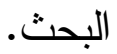

حدود الدراسـة: كانــت حسدود هــــه الدر اســـة كما يلي: - الي:

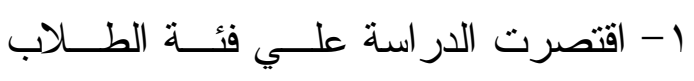

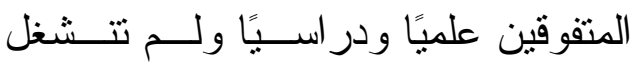
بالطلاب الموهوبين في الدجــال الفنـي

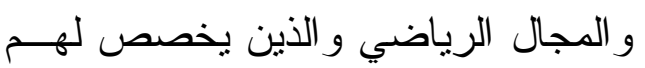
درجات نظير تقوقهم في هذه المجـالات في الثانوية العامة.

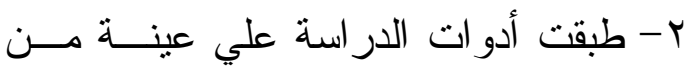

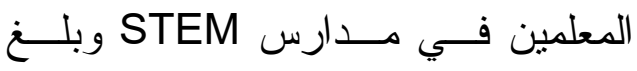

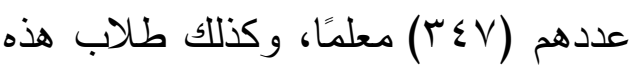
المدارس وبلغ عددهم (بV0) طالبًا.

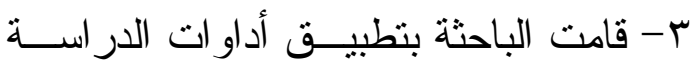
على عينة من المعلمين بنسبة (T،ریA\%)

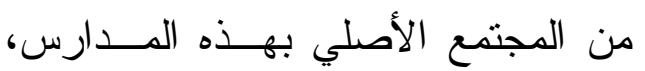
وكذك عينة من طلاب الــصف الثالــث

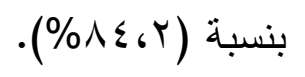

ـ - انتتملت عينة الدر اسة علي معلمين مسن

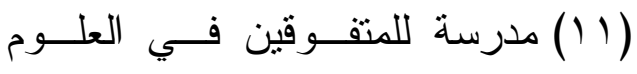

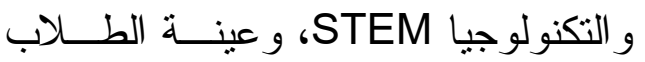

STEM، و الذي يتوقع من طالـبـ STEM إتقانه في ضـــوء تعلــيم STEM بالــدول

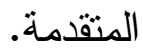
- إكساب الطلاب مهار ات تـساعدهم علــي

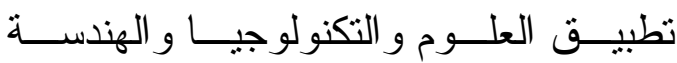
و الرياضيات في سياقات تــــبط المدرســـة ولهـ

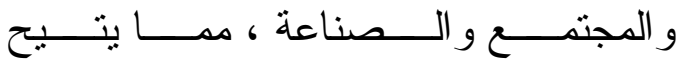
تطوير القدرة على المنافسة العالميــة فـــي الاقتصاد الجديد. - الوقوف علي و اقـــع مـــارس المتنـــوقين من وجهــة نظـــر المعلمــين و الطــلاب،

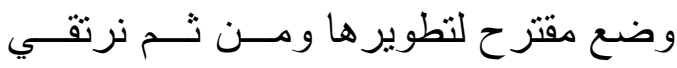
بالمجتمع.

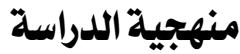

نظر اً لطبيعة هـــهـ الدراســة و أهــــافها

النظرية و الميدانية فإنها اعتمدت علي الرــنهج الوصفي بوجه عام و الذي يهدف إلي وصـف

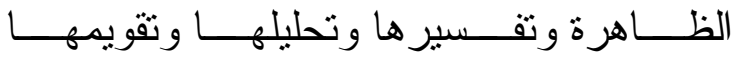
وتطوير ها، حيث تهنم البحوث الوصـفية بكــل من الظروف و العلاقات القائمة، و الممارسـات

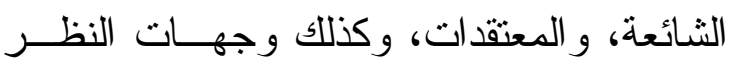

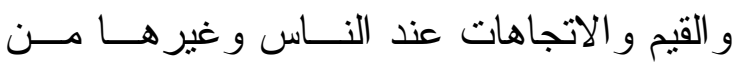

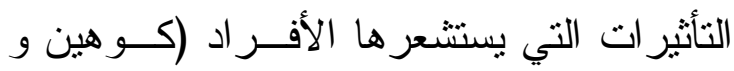

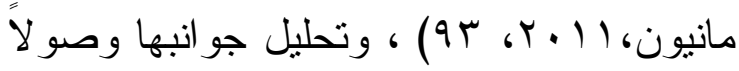
إلى رؤى مستقبلية لتحقيق الغايات المنـشـودة، فسعت إلي معرفة من المتفوقون وكيف تطــــور

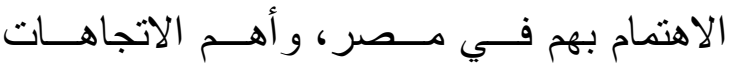

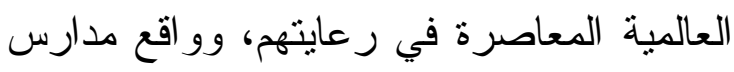


تكنولوجيا التعليم في STEM ، و البعض الآخر

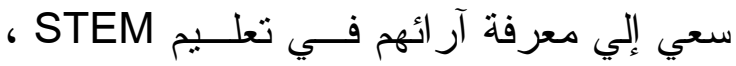

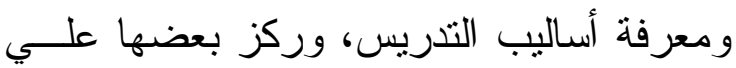

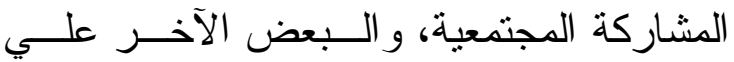

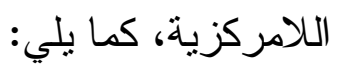

دراسات للوقوف علي آراء المعلمين في تعليم :STEM

Farzana, et al, عرضــت در استــة (2018) وجهات نظر المعلمين لأنشطة العلوم

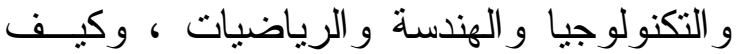
يفهمون دور هم كميـسرين أساسـيين وتـــأثنير

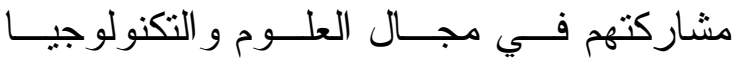
و الهندسة على تطور هم المهني، وأن التوعيــة

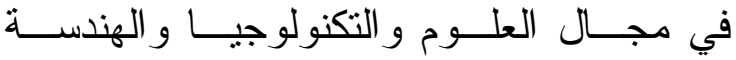

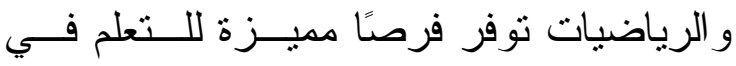
الأماكن المغلقة و الحوار.

وكثفت نتائج مقــابلات شــبه منظمــة

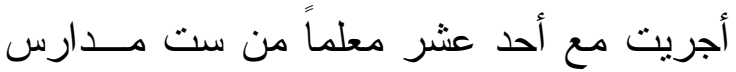
مختلفة في ويست ميدلاندز بالمملكة المتحدة أن

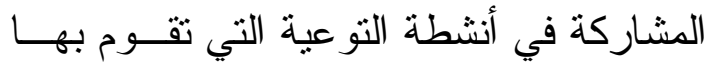

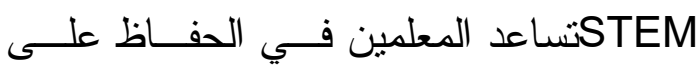
شعور هم بالهوية وتعزيــزهم كمحتــرفين فــي

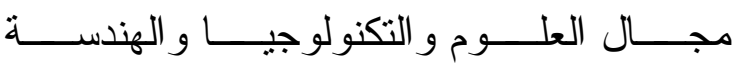
و الرياضيات، وتوفر أنشطة التوعيــة فرصًّــا

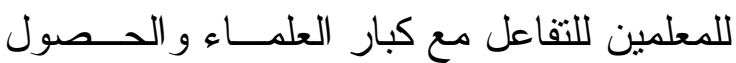
على الأبحاث المتطورة
من تسع مدارس فقط، وذلـــك باســتبعاد

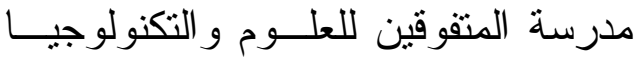
بكل من محافظة الغربية وكذلك محافظة

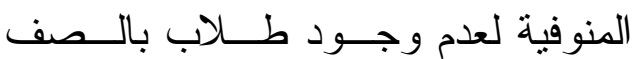
الثالث الثانوي بها. 0- ركزت أدوات الدراسة علــي محسـورين هما: الأول: و اقع مدارس المتفوقين من وجهة

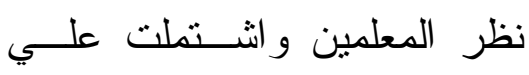

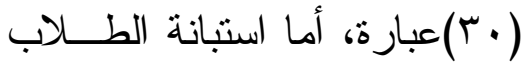
فتضمنت (10) عبارة فقط. الثاني: مقترحات عينة الدر اسة لتطــــير المدرسة وكانت عبارة عن سؤال

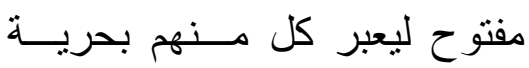

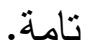

\section{الدراســات السابقــة}

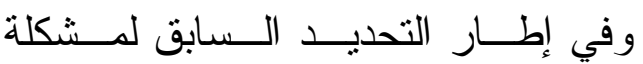
الدراسة تجدر الإثـــارة إلــي مجموعــة مــن

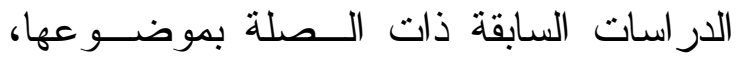

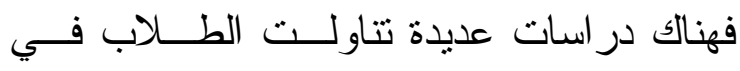
STEM وتتجيعهم علي الدراسة فـي مجــال

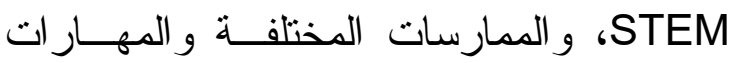

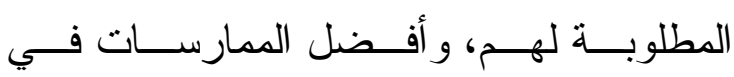
أكاديميات STEM، ومواجهة تسرب الطلاب،

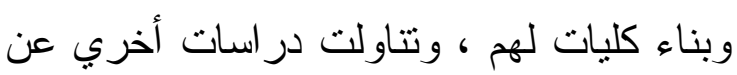

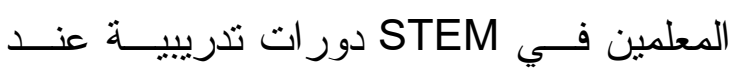

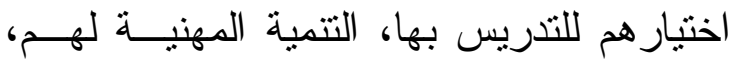

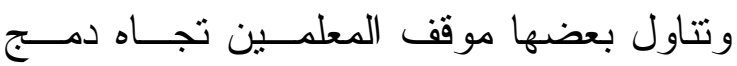


استخدام معظم الوقت بفعالية و لا يمكنهم إقامــة

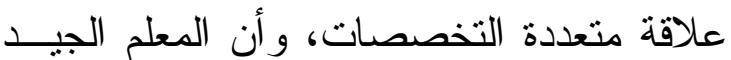

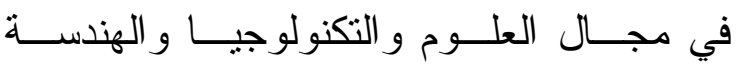

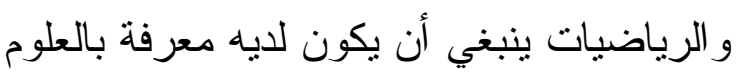

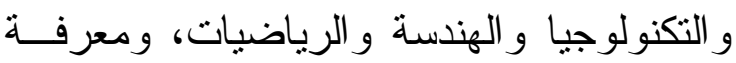
في مجال التدريس ومعرفة بمهـار ات القـــن الحادي و العشرين، إلا أنه بعد تدريب STEM

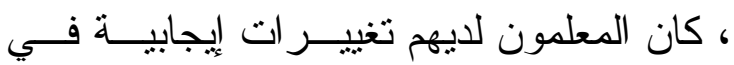
آرائه نحو الهندسة و التكنولوجيا.

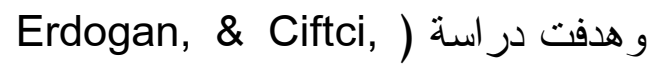

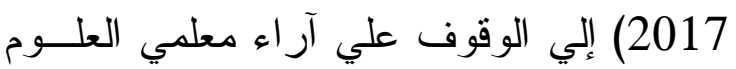

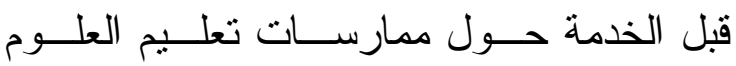
و التكنولوجيا و الهندسة و الرياضيات.

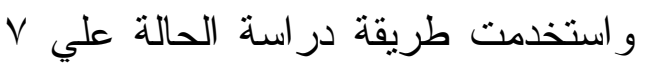
من معلمي العلوم قبــلـ الخدمــة مــن خــال المقابلات شبه المنظمة في الأنشطة البحثية وتم

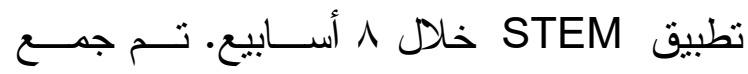
البيانات وتحليل المحتوى لها، لوحظ أن معلمي

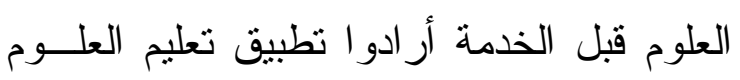

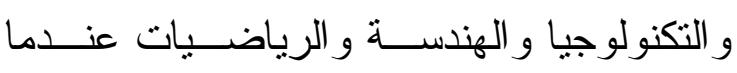
يصبحون مدرسين ؛ أرادوا الحـصول عالـى

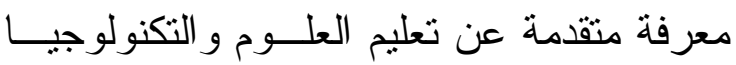

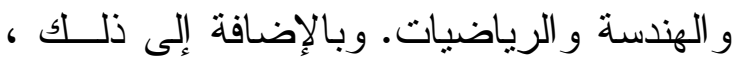
أعرب معلمو العلوم قبل الخدمة عـن آرائهــ بشأن الأساس المنطقي و الفو ائد و القيود المتعلقة

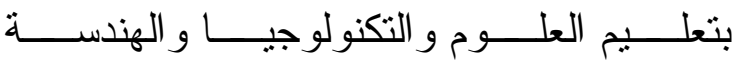
و الرياضيات ، وقدمو ا مقترحات لنطوير ونشر
و هدفت دراسة Çevik, \& Özgünay

(2018) إلى الوقوف علي تعليم STEM مــن

خلال وجهات نظر معلمي المـــارس الثانويــة ومديري المدارس في تركيا، و اعتمــدت علـى لـى

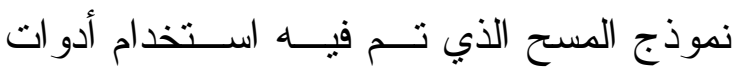

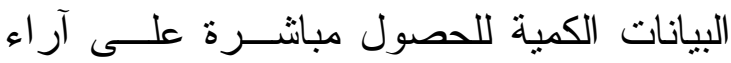

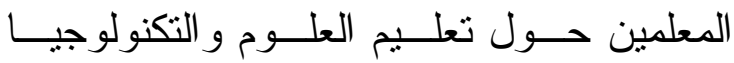
و الهندسة و الرياضيات، وتكونت عينة الدر اســـة من بـا معلمًا ميـــانيًا فــي مجــال العلــوم و التكنولوجيا و الهندسة و الرياضيات يعملون في

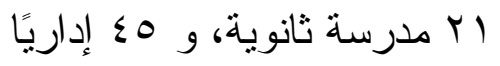
أثنارت نتائج آراء المعلمين إلى أن تأثثر

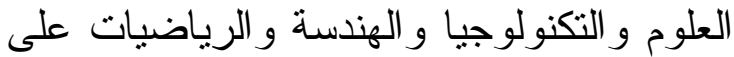

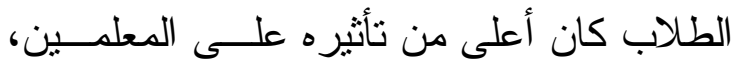

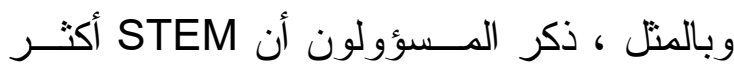

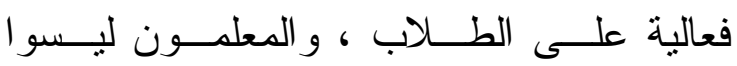
مجزين بشكل جيد لتدريس العلوم و التكنولوجيا

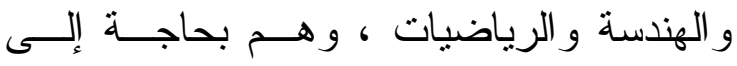
تدريب أنفسهم على تتفيذ STEM في الدورات

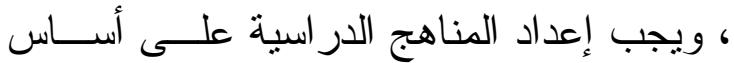
العلوم و التكنولوجيا و الهندسة و الرياضيات. وسـعت دراســة , Yıldırım \& Turk (2018 إلــي فحـــ آر اء معلمــي العلــوم و الرياضيات باسطنبول خلال فصل الربيع من

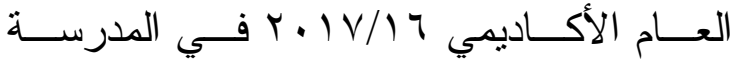

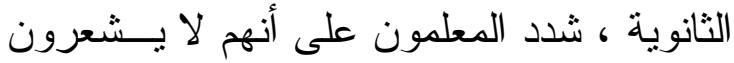

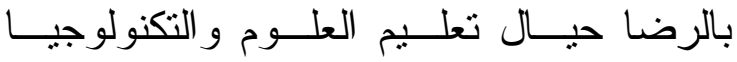
و الهندسة و الرياضيات، كما أنهم لا يستطيعون 
STEM في جميع أنحاء الو لايــات المتحــدة. حددو ا ما مجموعه 9 9 مدرسة فريــة مسن

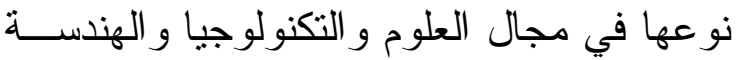
و الرياضيات من خلال البحــث فــي المواقــع الإلكترونية، ومر اجعة المقالات التي تم تحديدها

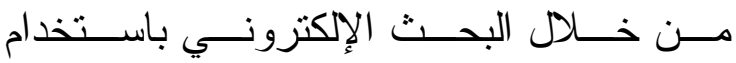

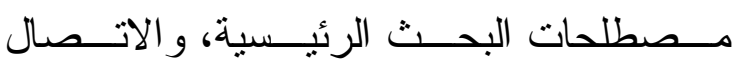

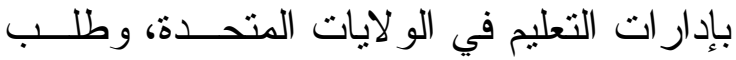

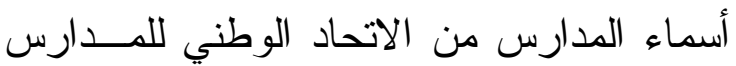

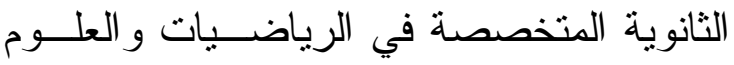

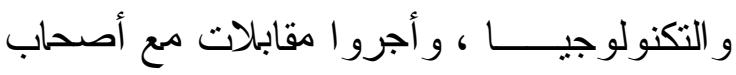

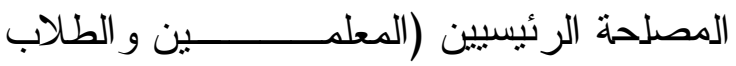

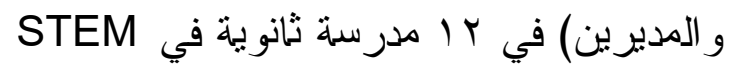
وباستخدام البيانات النوعية من هذه الزيارات ،

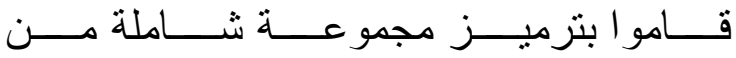
الاستر اتيجيات و المناهج الدر اسية و التنريسـية، و السياسات المدرسية، وعو امل النقافة المدرسية

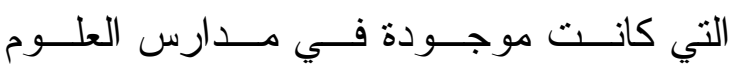
و التكنولوجيا و الهندسة و الرياضيات.

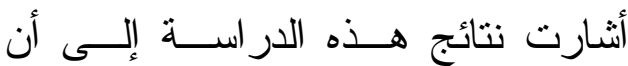

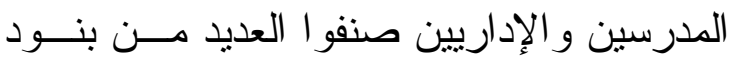
المسح ذات الصلة على أنها مهمة أو ضرورية الإدية ل للغاية.

وهـدفت دراســة \&amantha \& و

Sumaya, 2015) المعلمين ب STEM تجاه تكنولوجيــا التعلـيم التيم و العو امل المؤثرة في مو اققهم، وكثفت النتــائج أن مو اقف المعلمين كانت إيجابية بشكل عـام،

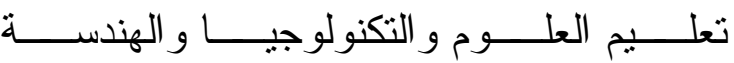

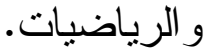

وعدت دراسة (Mustafina, 2016)

إلي استكثناف مو اقف المعلمين تجــاه تكامــلـ

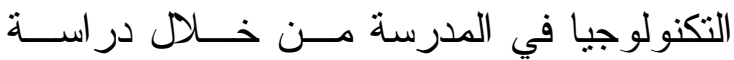
العو امل (الثقـــة بــالنفس و المعرفــــة و الجــس و العمر) التي تؤُثر على مو اقف المعلمين فـي لـي

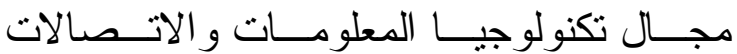

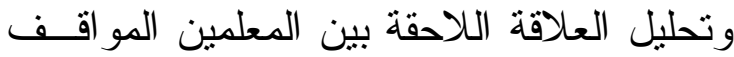
و الدو افع الأكاديمية للطلاب. أظهرت النتائج أن المعلمـين يمتلكـــون مو اقــف إيجابيــة تجــاه تكنولوجيا المعلومات و الاتصالات في المدرسة، ويرجع ذللك في الغالب إلى المز ايا التي توفرها

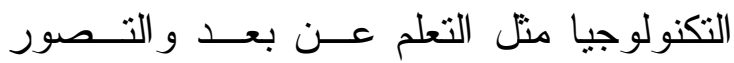
المرئي للمو اد (البر امج ثلاثية الأبعاد). عــلاوة

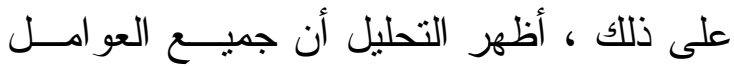

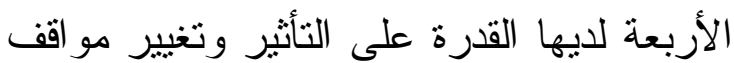

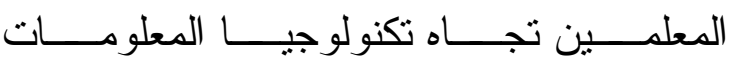
و الاتصالات و التي تؤثر في الدافع الأكساديمي

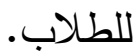

Forman, Jennifer et al, ) أما در اسة

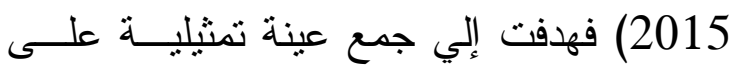
الصعيد الوطني لمفاهيم المــدر اء و المعلمـين

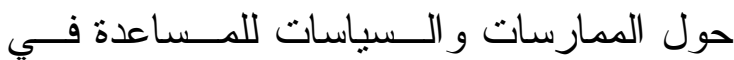
تحديد وتقييم المكونات الأساسية للتعلــيم الــــي

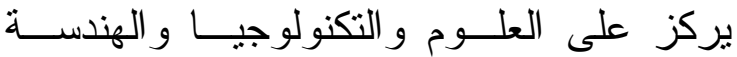
و الرياضيات، أجرى المؤلفون بحثًا موســـا لتقييم البرنامج الـــاخلي للمــــارس الثانويـــة 
و التكنولوجيا (PEST) في المملكـــة المتحــدة لاستخلاص الــدروس المـشتركة لمـشاركة STEM التطور التربوي للمدرسين، و اعتبــر الباحثان أن نجاحات الحوار العلمي في إرســاء

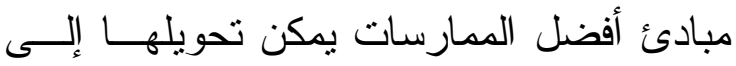
تطوير مهار ات المعلمين على أنها أكثر قـدرة وفعالية في إثــــر الك المتعلمـين فـــي العلــوم و التكنولوجيا و الهندسة و الرياضيات.

اهتــت دراســة (Knowles, 2017)

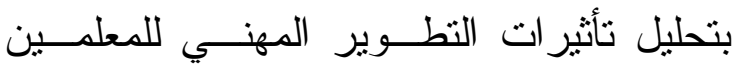
وتطبيــق الــــرس فـــي العلــوم المتكاملــــة و التكنولوجيا و الهندسة و الرياضيات (STEM)

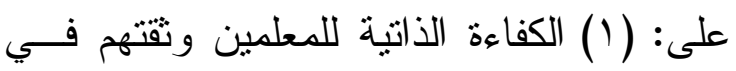
تدريس مو اضيع محددة في العلوم و التكنولوجيا و الهندسة و الرياضيات. (Y) تدريس معتقــدات

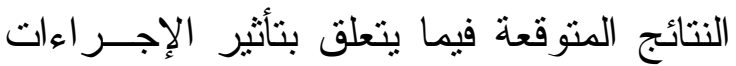

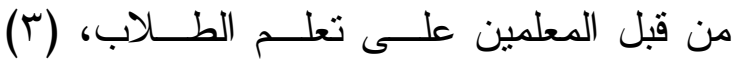

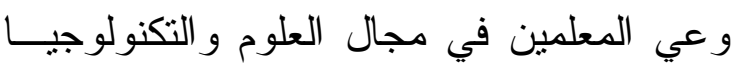

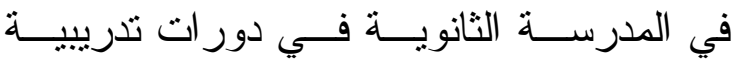
عن التقام في الدروس المتكاملة فـي دي دوني معهد تطــوير مهنـي صــيفي (TRAILS)"

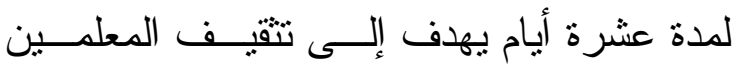

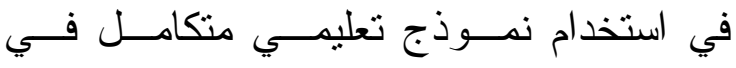

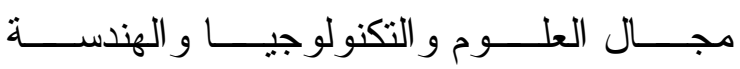
و الرياضـــات مــن أجــل تطبيــق العلـــوم

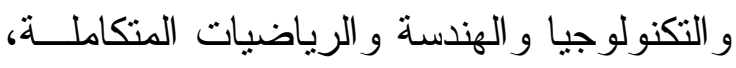
بينت النتائج العثّر على تأثير ات كبيرة للنطور
وهنالك خمس خطوات تجــاه الــدمج النــاجح للابتكارات التكنولوجية، وهي: المعرفة، القدرة

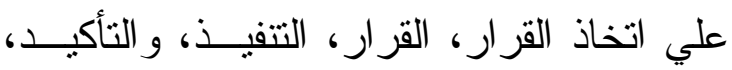
وتتضمن مرحلة المعرفة ما يقوم به الابتكــار

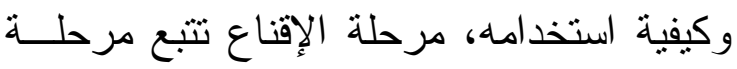

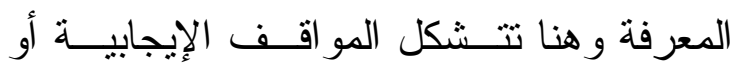

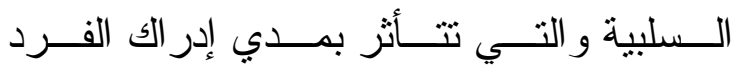

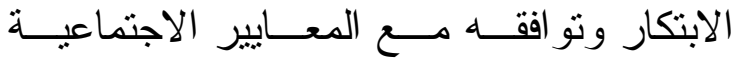

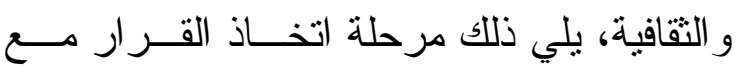
وجود خيار إيجابي يؤدي إلي التنفيذ و التأكيــــ في نهاية المطاف. دراسـات تبين أهميـة التنميـة المهنيـة للمعلمسين في تعليم STEM: و أكدت در اسة (Claudia et al, 2018) ضرورة التتمية المهنية للمعلمين وأنه يمكن أن

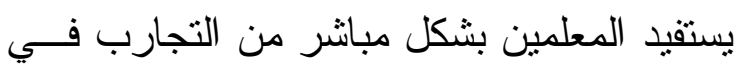

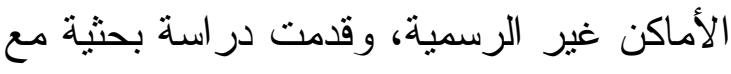

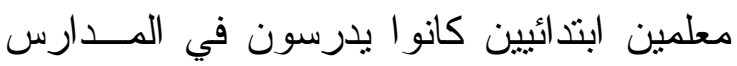

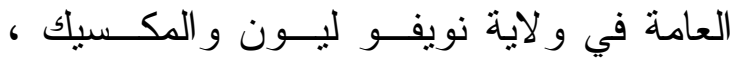

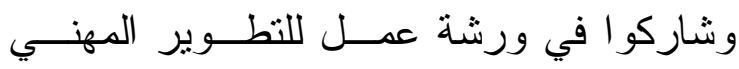

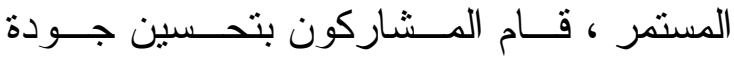
ممارساتهم التنديسية في الفــصول الدراســية

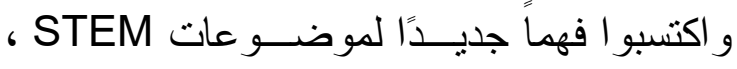

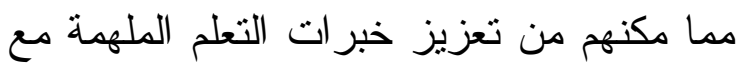

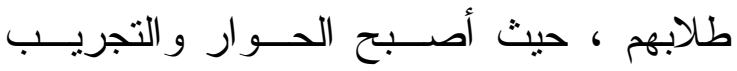
و التوضيح جزءًا مهمًا من دروسهم.

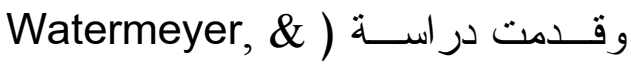
(Montgomery, 2018 لحالتن بارزتين من المشاركة العامة في العلوم 
الفصل ، وخطـــ الــدروس التـي صــمها

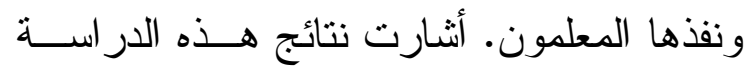
إلى أن الجلسات كانت فعالة في نقل العديد من المفاهيم الهامة حول التعلم القائم علي مــشروع .STEM

دراسات تبـين جـودة البـر امج فــي تعلـيم :STEM

وركزت دراسة ) Guzey, S. Selcen

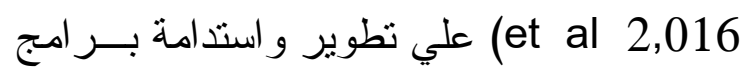

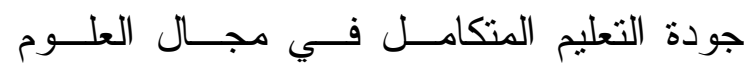

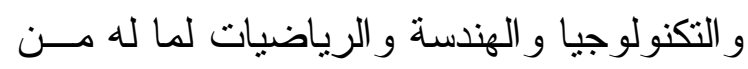

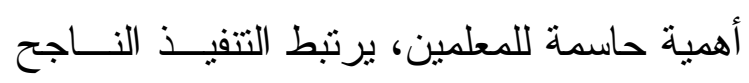
لأي برنامج من بر امج STEM بمو اد المنــاهج

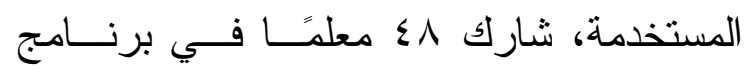

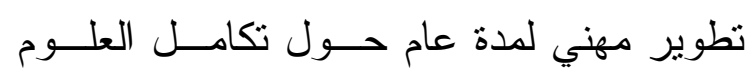

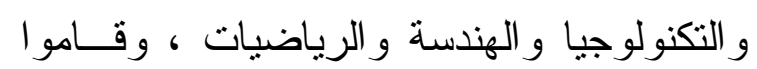

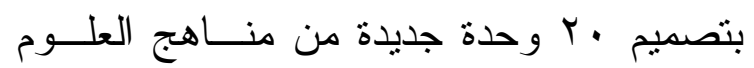

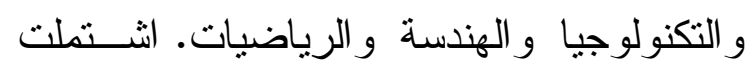

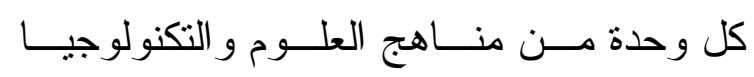
و الهندسة و الرياضيات على تحدي هندسي يقوم

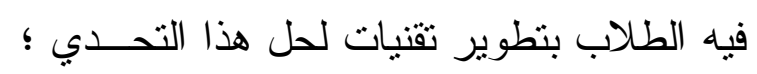

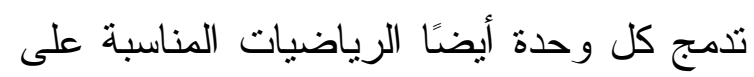

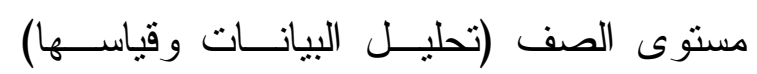

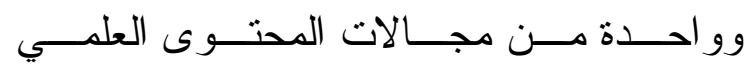

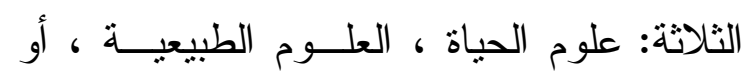

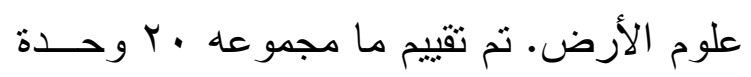

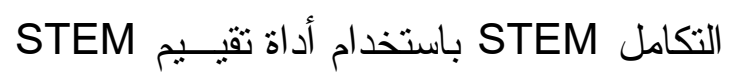

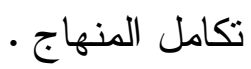

المهنـي TRAILS فـي مجموعـــة المعلــم (التجرييية أو المقارنة).

وبينت دراســة (Tyler, et al, 2017)

أنه عند اختيار معلم لتدريس منـــاهج STEM

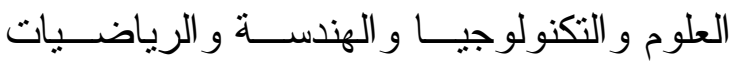
ينبغي تزويده بالدور ات اللازمة لنطويره مهنًِ و إكسابه الخبر ات المختلفة، لأن خبرة المــربين عامل رئيس في تقديم تعليم متميز ، نم اقتـــراح

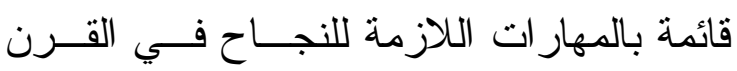

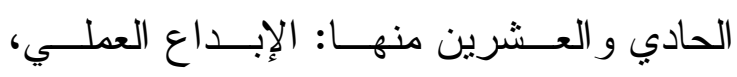

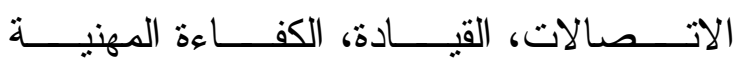
و الديناميكية، المرونة، خفة الحركــة، التقكيــر النقدي، حل المشكلات، التعاون، الابتكار ، محو

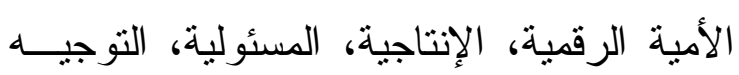

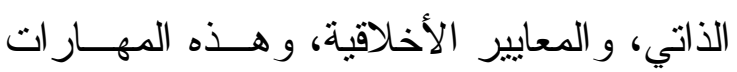

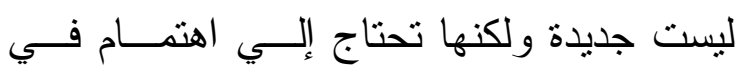

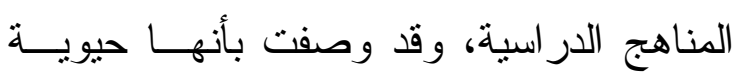
لاقتصاد مزدهر.

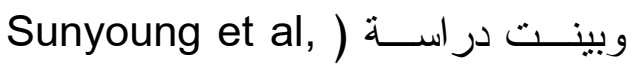
2015) قيام فريق بحثي فــي مركــز العلــوم و التكنولوجيا و الهندسة و الرياضيات (STEM) بتقديم أنشطة التطوير المهني بشكل منتظم وإلى ولى

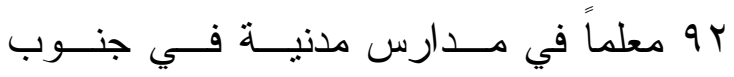
الو لايات المتحدة، للتحقيق في تطبيق المعلمـين فين فئن

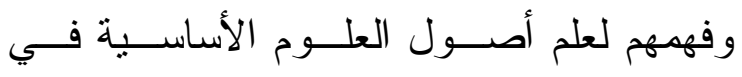
العلوم و التكنولوجيا ، تم إجر اء در اســـة حالــــة جماعية مع خمسة مدرسين وشــملت بيانـات الدر اسة : المقــابلات ، و الملاحظـــات داخـلـل 
ووضــــت دراســـة (Kaur, 2014)

تطور نظام التعليم في ســنغافورة منــــ أعلــن

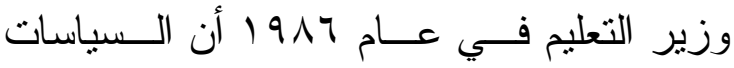
التعليمية المستقبلية في سنغافورة تتم من خلال

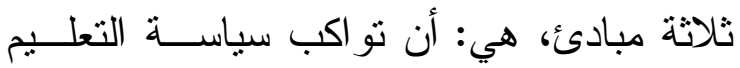

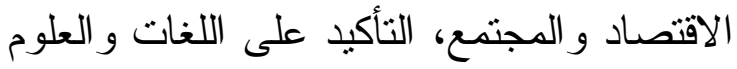

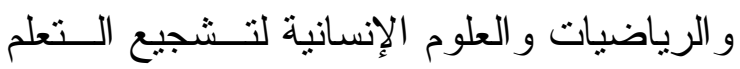
مدى الحياة، وتعزيز الإبداع في المدارس مسن الإنس

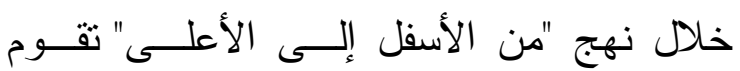

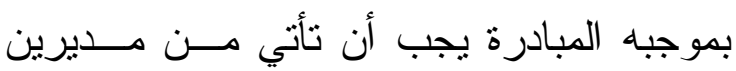
ومعلمين بدلاً من وزارة.

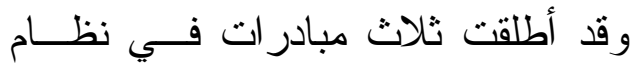
التعليم في سنغافورة في عـام V991، وهـي

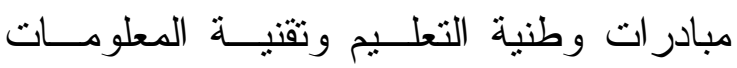
و التفكير النقدي و الإبداعي لتتكيل رؤية التفكير في المدارس، و المعلمون أحرار في ممارســة

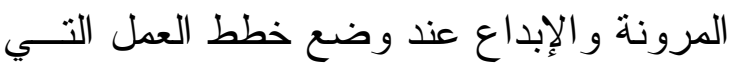
تكون بمثابة مخطط لتتفيذها، ورحلة التعلم تبدأ

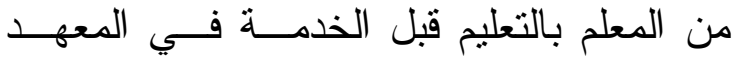

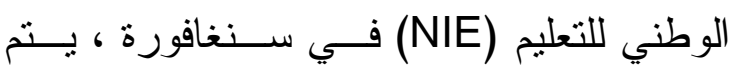
تدريب معلمي المدارس الثانويــة و الاعداديــة

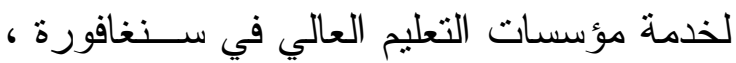
و البر امج و الدور ات في NIE باســتمر ار تمــر بالتغيير وذلك لمو اكبة التغيرات السريعة التـي تحدث سو اء محليًا أم على الصعيد الــدولي، و لـائر

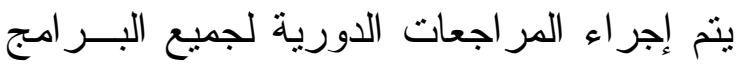
و إجر اء المر اجعات اللازمة.
و أظهرت المقارنات بين وحدات STEM أن الأنشطة الهندسية في العلوم الفيزيائية التي وحت ركزت على وحدات STEM كانت أكثر جاذبية وحفزًا مقارنة مع السياقات الحقيقية الدستخدمة

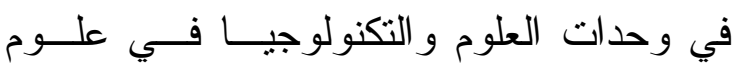

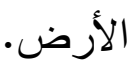

كمـــا أفـادت دراســة NATIONAL STEM SCHOOL EDUCATION STRATEGY, 2015)

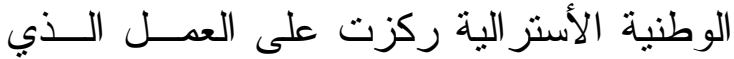

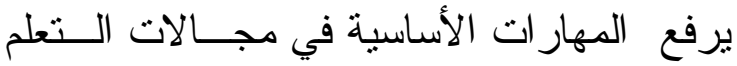

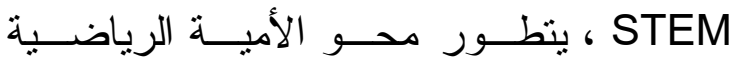
و العلمية و التكنولوجية ، ويعزز تطـــور القــرن الحادي و العشرين ؛ مهار ات حـل المـشكلات و التحليل النقدي و التقكير الإبـــاعي. يعتـــف لفه بأهمية التركيز على STEM فــي الـسنوات الأولى و الحفاظ على هذا التركيز طو ال التعليه،

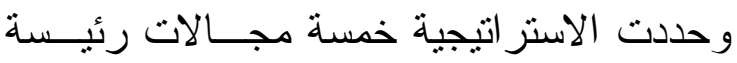
للعمل الذي من خلاله يكون التعليم المدرسـي لديه أكبر قدر من النفوذ، وهي: زيادة قــدرة

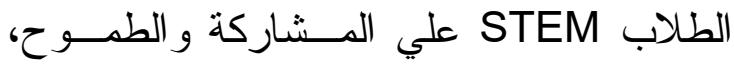
زيادة قدرة المعلم في STEM علي تحقيق جودة

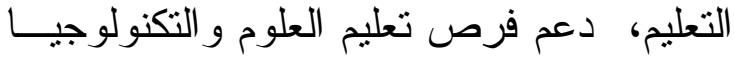
و الهندسة و الرياضيات داخل النظم المدرسـية،

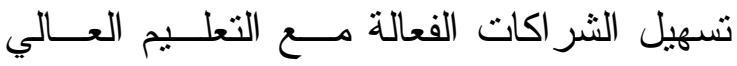

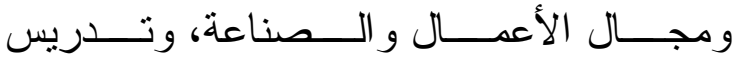
الإصـاحات لافع التحسينات في تعلــيم العلــوم و التكنولو جيا و الهندسة و الرياضيات. 
و إذا تم تقديم تعليم ريادة الأعمال فــي تعلــيم

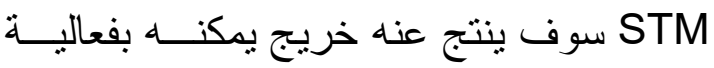
إدارة أعماله الثخصية.

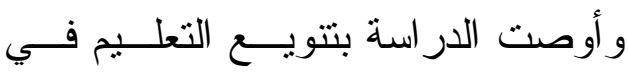
مجال العلوم و التكنولوجيا، وجعله أكثر فاعلية، وموجهاً نحو حل مشكلات المجتمع المعاصـر . تحقيقا لهذه الغاية ، ينبغي إعادة هيكلتها لتعكس التحاهن ريادة الأعمال بحيث يكون الخريجين معتمدين

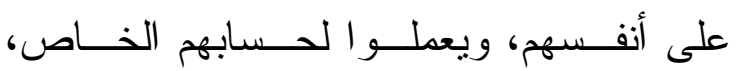
وبالتالي ينبغي أن يكون تعليم STM أولوية في لفي

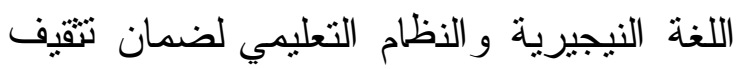

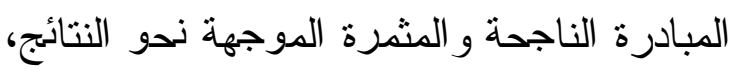

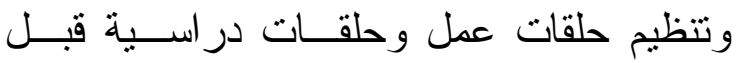
الخدمة و أثناء الخدمة للمعلمين.

دراسات تبين أفضل الممارســات فــي تعلـيم :STEM

أما در اسة (Kasza \& Slater, 2017)

فبينت أفضل الممارســات فــي أكاديميــات STEM

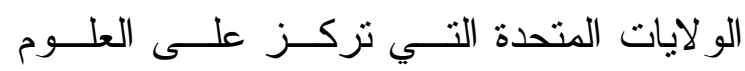

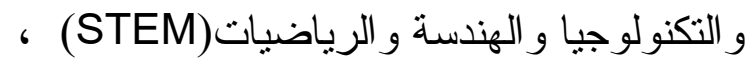
تم الكثف عن تكامل الموضــوع ، وتــصميم

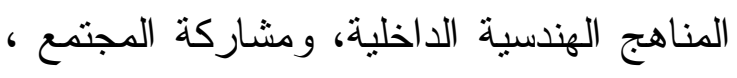
و التدريب الداخلي على أنها تعكس باســتمرار

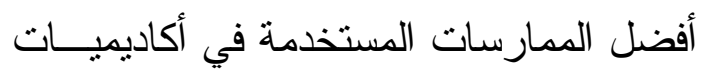

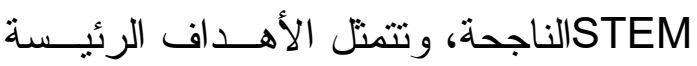
للتعلم المتسقة في الأدبيات وفي نتائج المقابلات
وأوصت الدراســة باسـتمر ار تطـــوير المعلمين وتتميتهم مهنيًا لأن جودة نظام التعليم تكمن في جودة معلميها. وأظهرت در اســة ) Billiar, Kristen,

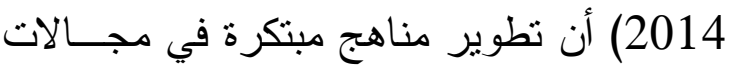

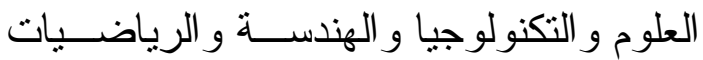

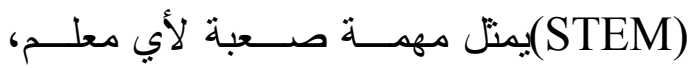

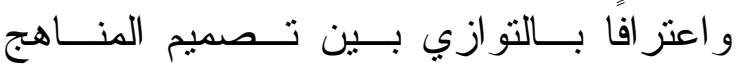

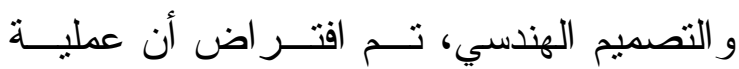
التصميم الهندسي (EDP) يمكـن اســتخدامها كوسيلة مبتكرة وفعالة ومنطقية لإضفاء الطابع

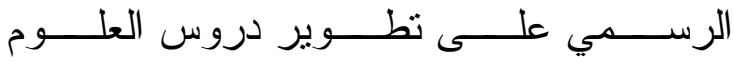

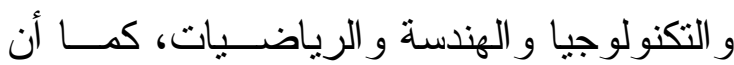
تحديد الطــلاب و المعلمــين كعمــلاء لعمليــة التصميم هو نهج يركز على المتعلم ، ويـشجع التعلم القائم على حل المشكلات (PBL) الـــتعلم

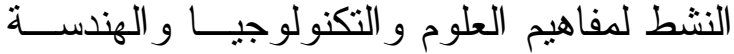
و الرياضيات في سياق المشكلات الحقيقية، تــم الاستعانة بعدد 10 معلمًا علــى مسـدار ثـلاتث

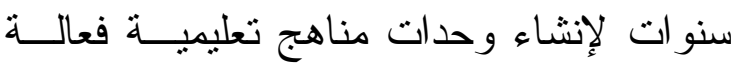

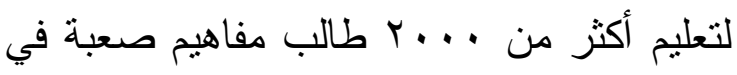
العلوم و التكنولوجيا و الهندسة و الرياضيات.

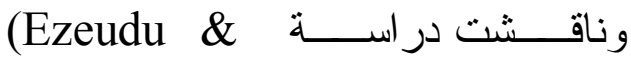

الحاجة إلى إعادة هيكــــة Ofoegbu, 2013)

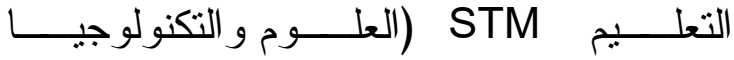
و الرياضيات) لريادة الأعمال في نيجيريــا لأن تعليم STM لم يحقق هدفه المتمنل في جــل لئل الخريجين قادرين علي الاعتماد على الــذات، 
الاستكثنافي علــى أداء الطــلاب فـــي الــتعلم

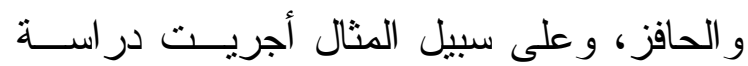

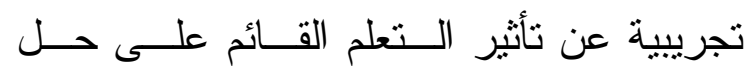
المشكلات في أداء الرياضيات -هو أحد أكتــر

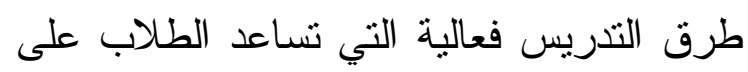

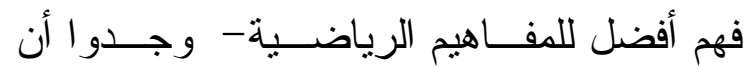

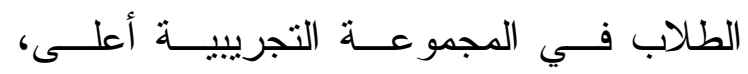

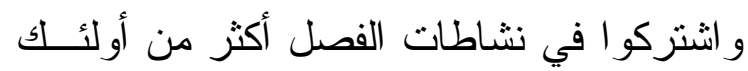

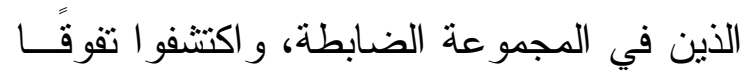
كبيرًا في البحث الموجه ضد طريقة التـدريس التقليدية.

دراسات تبين تأثير تعليم STEM في الطلاب:

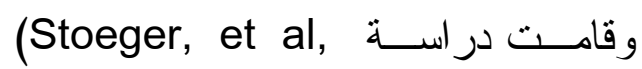

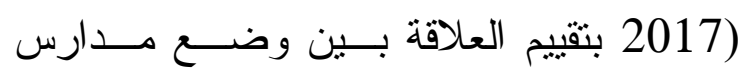
Magnet و التكنولوجيا و الهندسة و الرياضيات (STEM)

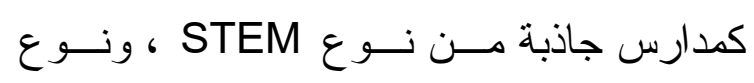

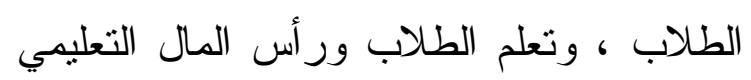

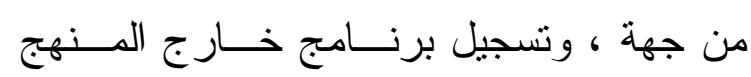

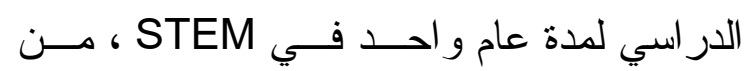

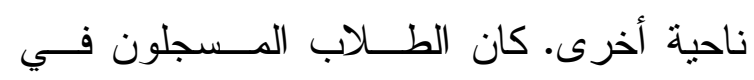
مدارس STEM ذات الكفاءة العالية ، وكــللك

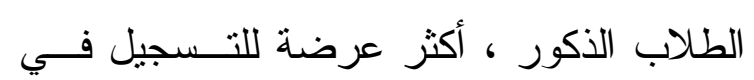
البرنامج اللامنهجي.

دراسات تبين آراء الطلاب في تعليم STEM: و هدفت در استــة (Popa \& Ciascai, 2017 إلى استقصاء رأي عينة مكونــة مــن
في: حل المشكلات في عملية التصميم الهندسي

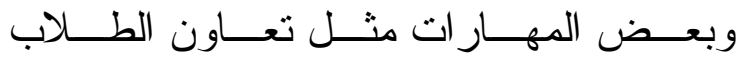

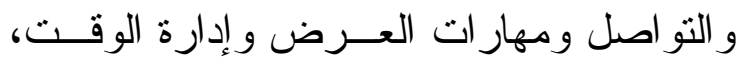

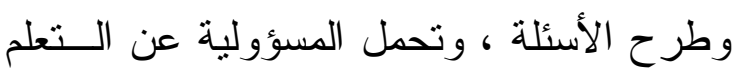
الثخصي ، و القيادة. أسفرت المقابلات عن مجمو عة متتو عـــة

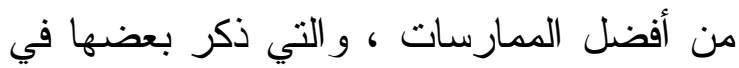

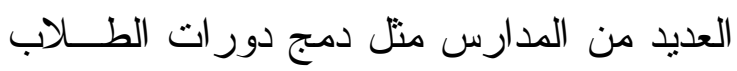

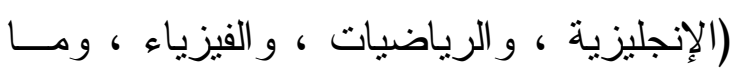

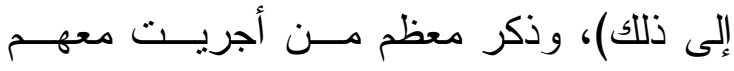

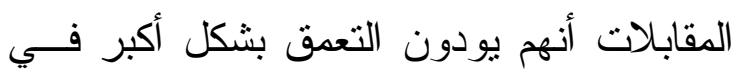
تطوير موضوع التكامل في أكاديمياتهم.

دراسات تبين أنماط التعلم في تعليم STEM:

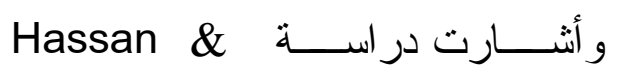
(lbrahim, 2018) يعودو ا مهتمين بالوسيلة المتمحورة حول المعلم

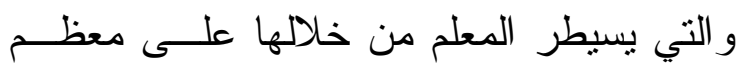

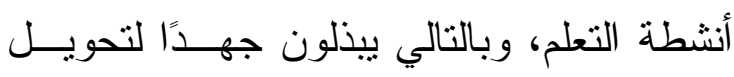

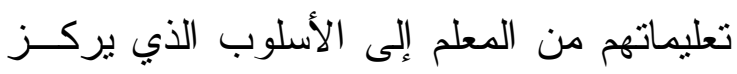

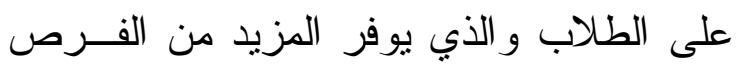
لاكتشاف الحقائق العلمية وحلول الرياضـيات بأنفسهم، ولديهم تصور ات بأن المعلم المتمركز

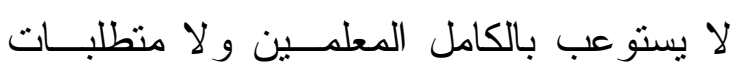

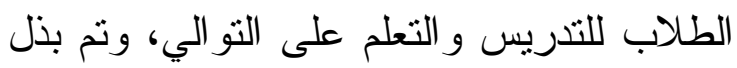

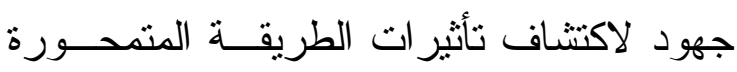
حول الطلاب منل الــتعلم القــائم عـــى حـلـل

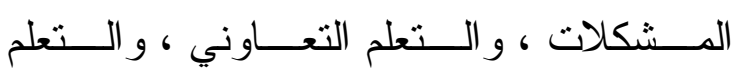


على المرحلة الثانوية مــن التعلــيم المدرســي

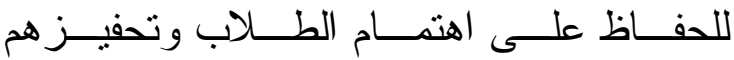
للانخر اط في STEM ، (2)تقفيذ الممارسـات التزبوية الفعالة لزيادة اهتمام الطلاب وتحفيزهم

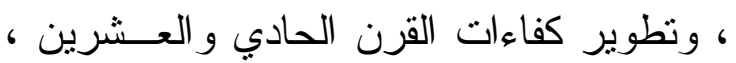
وتحسين تحــصيل الطــلاب ، و (r) تطـــــير المعلمين ذوي الجودة العالية للتأثير إيجابًا على لهى

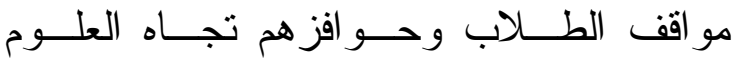
و التكنولوجيا و الهندسة و الرياضيات و أكـدت دراســة Rakich \& Tran,

(2016) علي ضرورة توفير فرص تعليميـــة

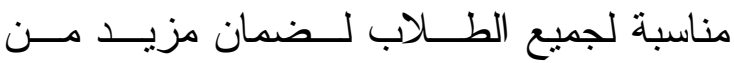

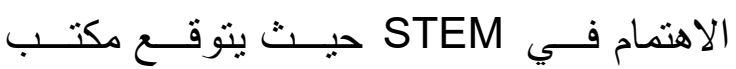
الإحصاء في الولايات المتحدة أن عدد الطلاب الجامعيين في STEM سينخفض بمقدار مليون

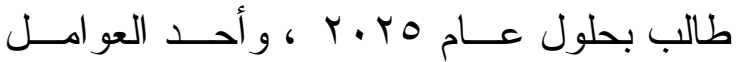

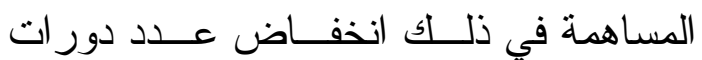

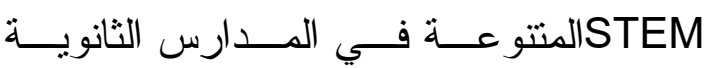

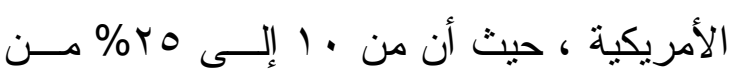

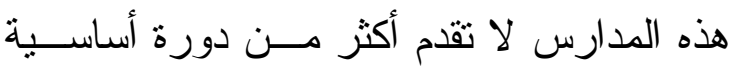

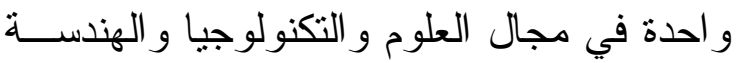
و الرياضيات، مما يؤكد على أهمية بناء كليــة

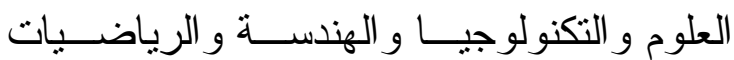
لطلاب الددارس الثنانوية. و أنثارت در اسة (Sumen \& Calisici,

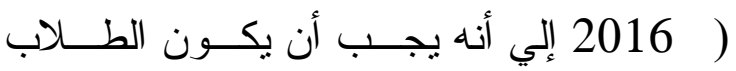

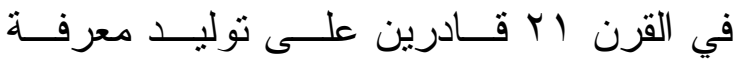

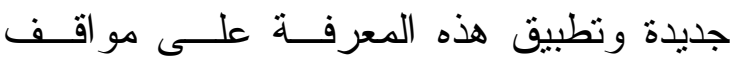

• 11 طالب من الجامعــات الرومانيــة ، مــع

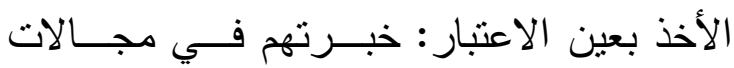
العلوم و التكنولوجيا و الهندسة و الرياضيات أثناء الدر اسات الثانوية، مهنة المهندس ومهار اتــه، و العو امل التي أثرت في اختبارهم لدراسة أحســ

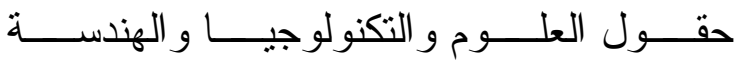

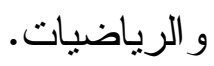
و أظهرت النتائج أن المسـتقنتين كــانوا مهتمين بمجالات العلوم و التكنولوجيا و الهندسة و الرياضيات منذ المرحلة الثانوية، وحدد هـــا

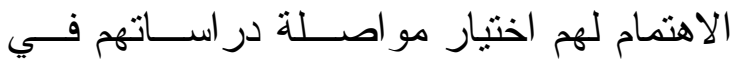

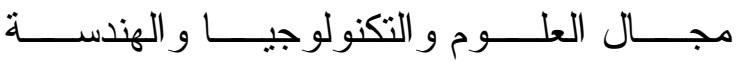
و الرياضيات. كما اتفق معظمه على أن اختيار تخصصهم الجامعي قد تأثز بــالمعلمين الــذين قامو ا بتعليمهم في مدارس STEM.

دراسات تبين عوامل انخراط الطلاب في تعليم :STEM

وناقـشت در اســة , McDONALD )

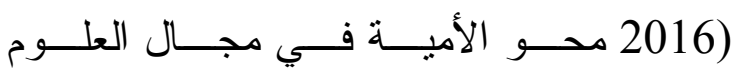

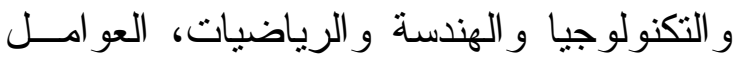
التي تؤثر على انخر اط الطلاب في تعليم العلوم

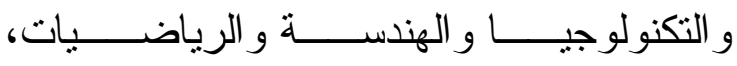

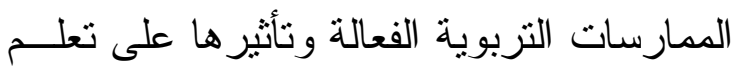

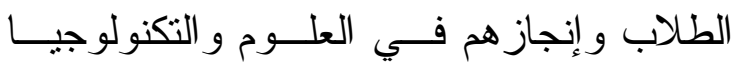
و الهندسة والرياضيات، ودور المعلم في تعلــيم العلوم و التكنولو جيا و الهندسة و الرياضيات مــن ولرئ

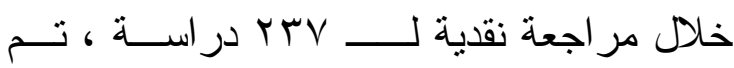
تحديد ثلاثة عو امل رئيسية: (1) أهمية التركيز 
هناك أيضا دليل يدعم أن التدخلات التي تعقب

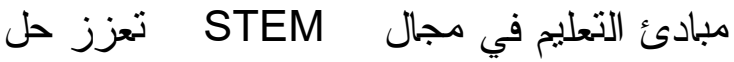
مشكلات الطلاب و إبداعهم.

دراسات تبين معوقات اهتمام الطلاب بتعلـيم :STEM

و استعرضت در استسة (Sithole et al,

2017) الطلاب وحرصهم علــي النجــاح و المثنـابرة في بر امج STEM و الممارسات المؤسسية التي وحتي

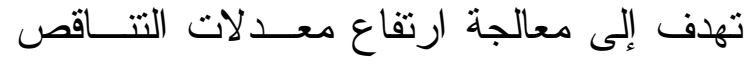

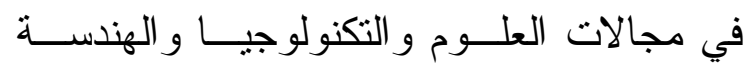
و الرياضيات، وشملت الاستراتيجيات المؤسسية المقترحة لتحسين الثبات فـــي بــر امج العلــوم و التكنولوجيا و الهندسة: توفير برامج التوجيه ،

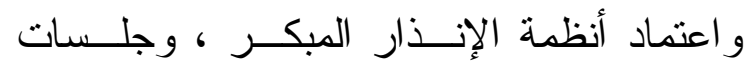

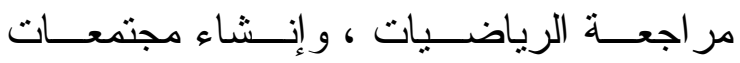
التعلم للطلاب ، و التطوير المهنـي لأعــضاء

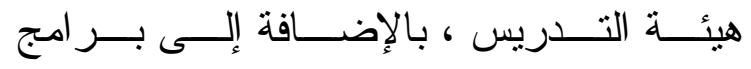
التوعية

دراسات تبين أهميــة المعسكرات الـصيفية للطلاب في تعليم STEM: دراب تين اهمين

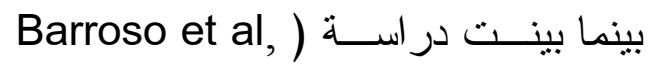

2018) أن لغة STEM الانضباطية بند STEM (disciplinary language

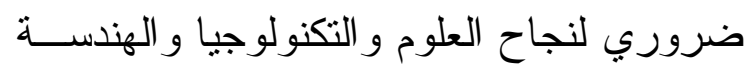

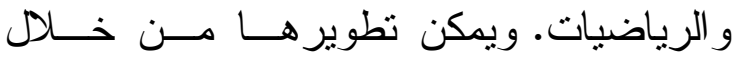

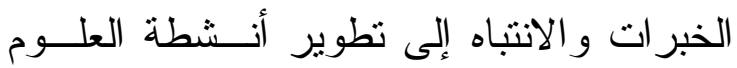

ومشاكل جديــدة بــلا مــن حفــ المعرفــة

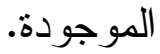

وتوصى بتدريب المعلمين قبل الخدمسة

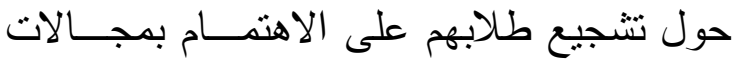
العلوم و التكنولوجيا و الهندســــة و الرياضـــيات الهات STEM و واختبار المهن المرتبطة بذللك .

وقد هدفت در اســة ) Yildirim, Bekir,

2016) إلي رسم الخطوط العريضة للار اسات البحثية التجريبية التي أجريت على تعليم العلوم و التكنولوجيا و الهندسة و الرياضيات مع التركيز على تحصيل الطلاب ، بالإضافة إلى مهار اتهر

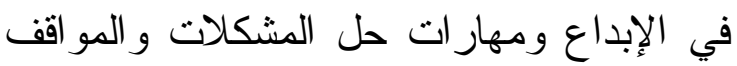
و الاهتمامات تجاه مو اضيع العلوم و التكنولوجيا

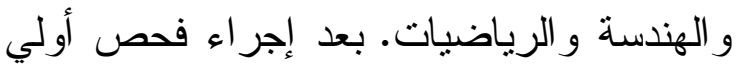
لعدة مقالات و أبحاث ورسائل حول تعليم العلوم و التكنولوجيا و الهندسة و الرياضيات ، تم اختيار

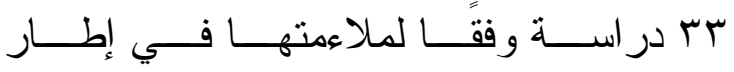
البحث. - (البث.

تم تحليل هذه الدراسات المختـــارة بمــــا

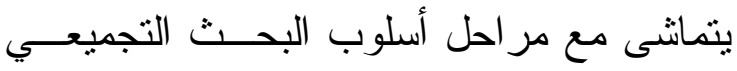
لتحديد النتائج وعرضها في إطار الموضوعات

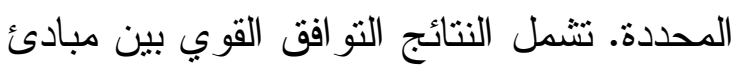
تعليم العلوم و التكنولوجيا و الهندسة و الدر اســات

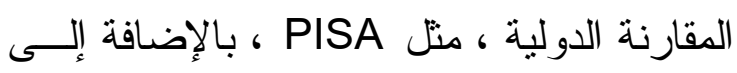

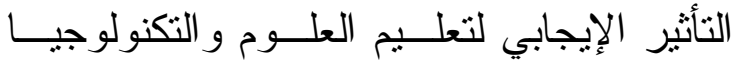

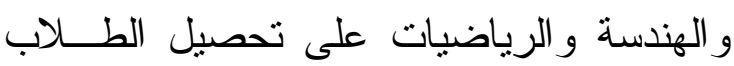

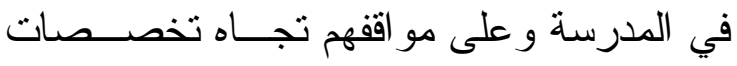
العلوم و التكنولوجيا و الهندســـة و الرياضــيات. 
2018)، و التــأثثر الإيجــــي لتعلــيم العـــوم و التكنولوجيا و الهندســة و الرياضــيات علـى تحصيل الطلاب في المدرسة وعلـى مـــو اقفهم تجاه تخصصات العلوم و التكنولوجيا و الهندســة و الرياضـــيات (Yildirim, Bekir, 2016) ،ومو اجهة تسرب الطلاب در اسة (Sithole et) STEM و al, 2017) .(Rakich \& Tran, 2016) وتتاولت دراسات أخري عن المعلديـين

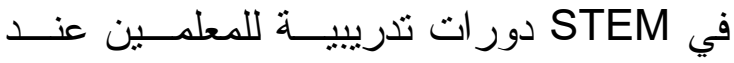
اختبار هم مثل دراسة (Tyler, et al, 2017) (Ezeudu \& Ofoegbu, 2013)، ، التنميـة (E) (Claudia et al, المهنية للمعلمين مثل در اسة المة ، (Knowles, 2017) 2018) (Kaur, ‘( McDONALD , 2016) ،(Ezeudu \& Ofoegbu, 2013)، و2014)

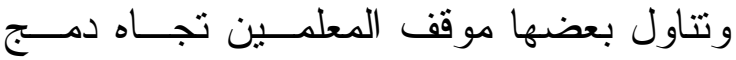

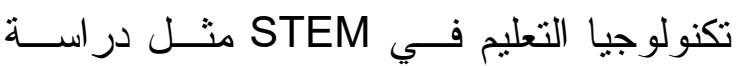
‘(Samantha \& Sumaya, 2015) Farzana, et al, و،(Mustafina, 2016) (2018)، و البعض الآخر سعي إلــي معرفـــة

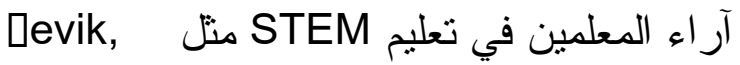
Yıldırım \& )، (\& Dzgünay 2018) Forman, Jennifer et ) ،(Turk, 2018 al, 2015 )، ومعرفة أساليب التدريس في تعليم Hassan \& Ibrahim, مثنـل STEM .(2018)
و التكنولوجيا و الهندسة و الرياضيات التي هـي غنية باللغة ويمكن اكتسابها من خلال الخبرات العملية و الممارسات المنهجية. شارك طــابلاب الثانوية في معسكر صيفي غير رســي فــي Google حيـث تعلمــو الســتخدام STEM

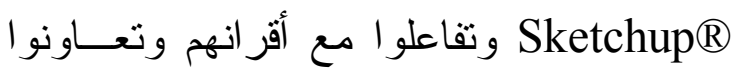
في القضايا عند ظهور ها لحل المشكلات. وبينت النتائج أن المشاركة المجتمعية في

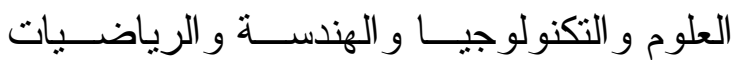

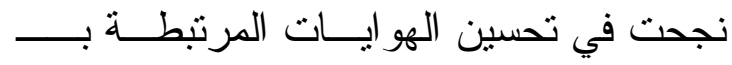
، STEM وازدياد الاهتمام بوظائف STEM

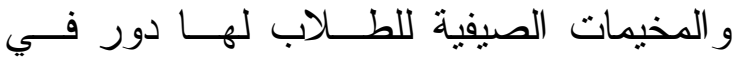
مشروعات مجتمعية بمشاركة شركات محليــة لاعم أنشطة المعسكر ات. وبذلك تتاولت بعض الدر اسات الــسابقة عن الطلاب في STEM تشجيع الطلاب علـي الدراسة في مجال STEM مثل در اسة Popa) Sumen \& ) \& Ciascai, 2017) McDONALD , ‘(Calisici, 2016

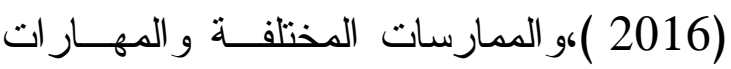

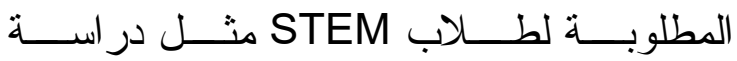
(Tyler, et ،(Erdogan, \& Ciftci, 2017) (NATIONAL STEM ، al, 2017) SCHOOL EDUCATION STRATEGY, (2015، (Billiar, Kristen, 2014)، و أفضل الممارســات فــي أكاديميــات STEM مثنـل دراســــة (Kasza \& Slater, 2017) Watermeyer, \& Montgomery, ) 
1- التفوقTalent : فى المعنى اللغوى مـن

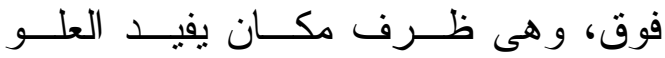

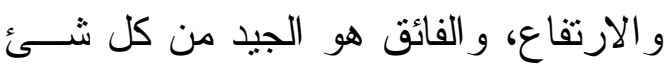
و الممتاز على غيره من الناس، ويقال فاق

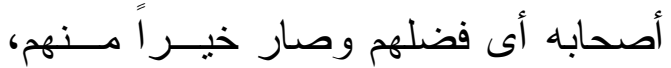
وتفوق على قومـــه فــاقهم(مجــــع اللغـــة

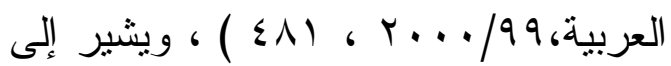
الأداء المتميز في واحد أو أكثر من ميادين

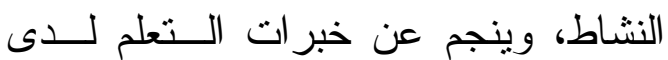
التلميذ.

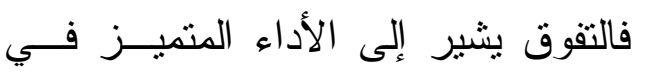
واحد أو أكثر من ميادين النشاط، وهي تكـــن الني

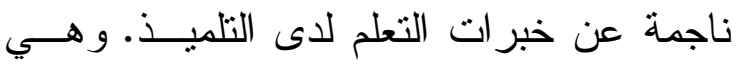
تعريفات تعكس الحد الفاصل بين القدرة و الأداء من خلال الاعتر اف بأهمية القدرات الفطريسـة،

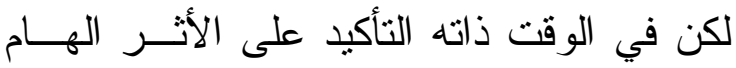

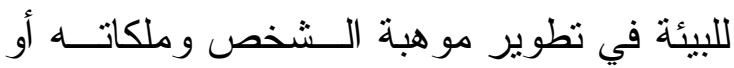
Rosalie Primary School, ) تثنيطهــا

ץ- و المتفوقون Talented : هــــــــلاب الطـاب الذين يتعلمون بـسرعة تفــوق زملائهـــ

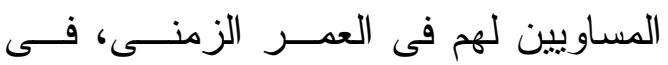

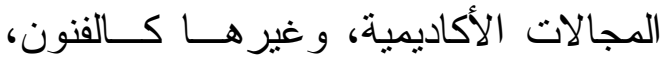
وهم الذين يصلون فى تحصيلهم الدراسـى

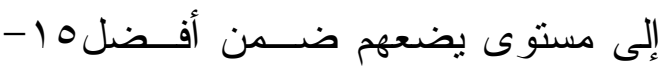
\% من المجموعة التى ينتمون إليهــا،

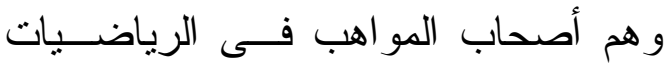

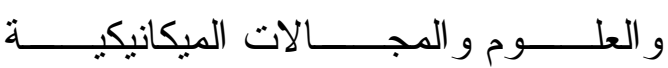

وركـزت در اســة ) Barroso et al,

2018) علي المشاركة المجتمعية مع مسـدارس درس

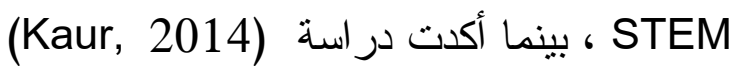
علي اللامركزية. وقد استفادت الدر اسة الحالية مــن هــــه

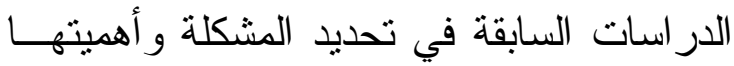

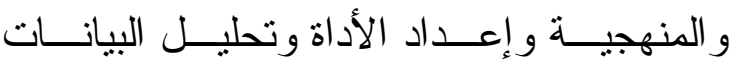
و ت تقسير ها.

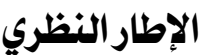

تتاول الإطار النظـــــي لهـــه الدراســـة

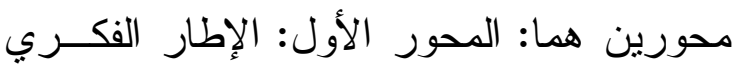
لرعاية الطلاب المتفوقين في مصر، و المحسـور الثاني: الاتجاهات و الخبر ات العالمية المعاصرة

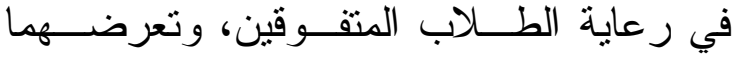
الباحثة فيما يلي: اليه

\section{المحسـور الأول: الإطــــر الفكـــري لرعايــة الطـلاب} المتفوقين في مصر الإطرا تتاول المحور الأول بعدين هـــا؛ الأول:

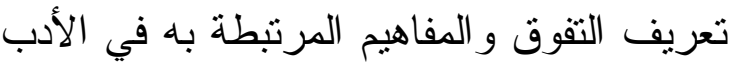
التزبوي، و البعد الثاني: تطور رعاية الطــلاب المتفوقين في مصر ، كما يلي: أولاً: تعريف التفوق والمفاهيم المرتبطة بــهـ

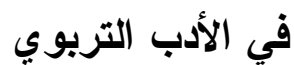
يوجد تداخل بين بعض المفاهيم كالتقوق، الموهبة ، الإبداع، وتـستخدم بـنفس المعنـي ويرجع ذلك إلى الاستخدامات المتباينة لها مــن الإنـ

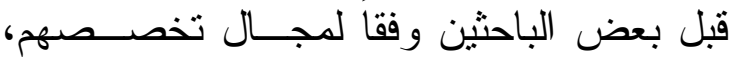
وفيما يلى توضح الباحثة هذه المصطلحات: 


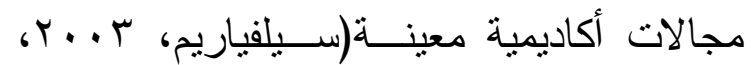
. (^v

ويتميز الطفل الموهوب بسرعة الــتعلم، و التفكير في حلول كثيــرة لمسشكلة محسدةة،

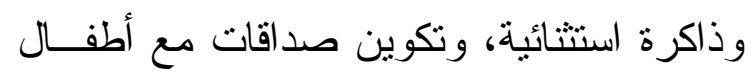

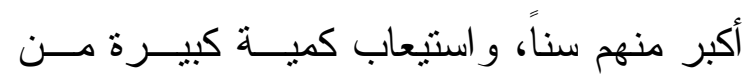

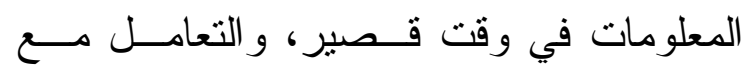

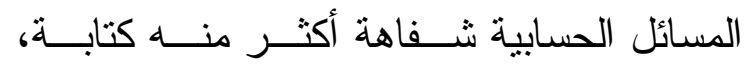
و القر اعة بـسـر عة، وتوجيـــهـ أســـئلة كثيـــــة.

(Farrall, 2007, 41)

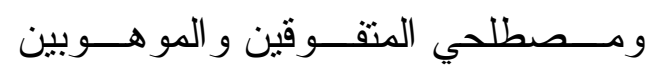

متمايزين وليسا متر ادفين، حيــث يـشير الأول

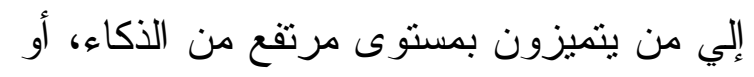

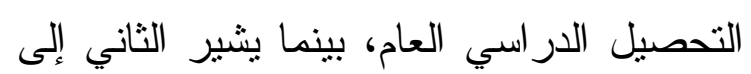
من يتميزون بقدرات خاصة تؤهلهم للتفوق في لئي

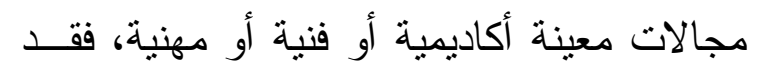
يتميز بعضهم في الرياضيات و البعض الآخــر

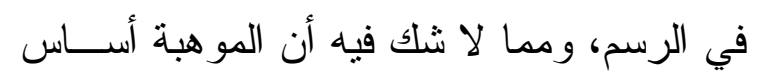

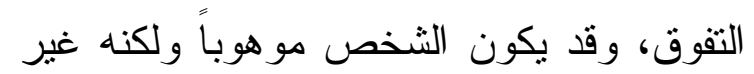
متفوق بسبب ما قد يصادفه من عقبات تـــؤدى إلى ضعف مو هبته.

ع - الإبداع Creativity : إن الابداع في اللغة

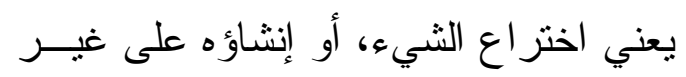

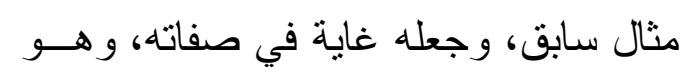

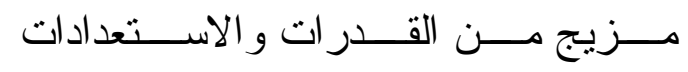

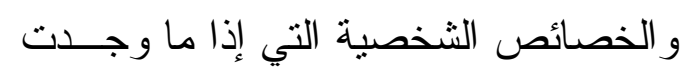

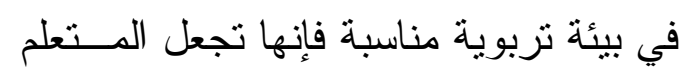

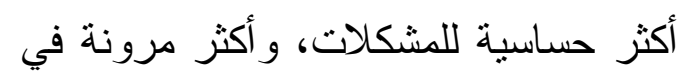

و القيادة(المجلس القومى للتعـــيم و البحــث

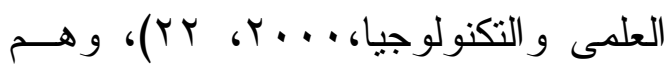
يختلفون عن الموهوبين وهم الطلاب الذين عُرفو البأنهم ذوو القدرات المتميزة في الفن

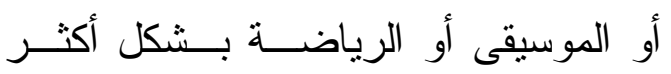

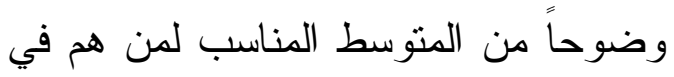

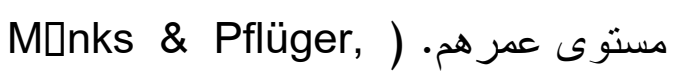
(2005,10

ب- الموهبــــة The Giftedness

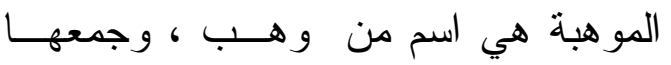

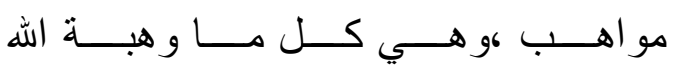

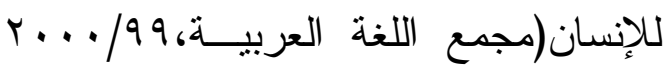

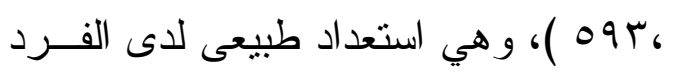

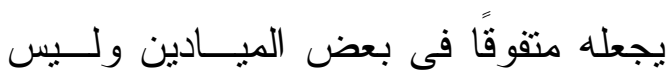
بالضرورة أن تتطوى المو هبة على درجة

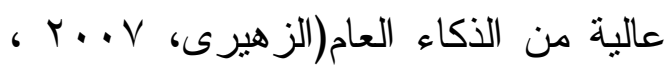
ror

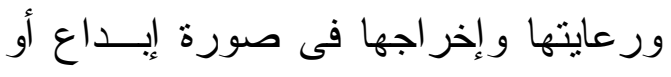
تفوق، وبذلك تتبر الموهبة إلــى القــدرة

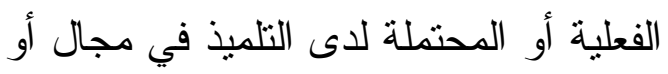

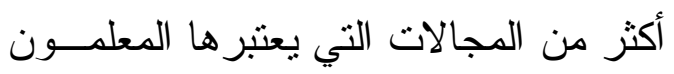
أو الآباء خارج نطاق قدر ات التلاديذ.

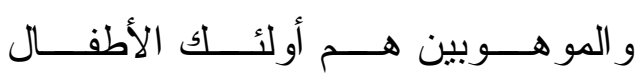

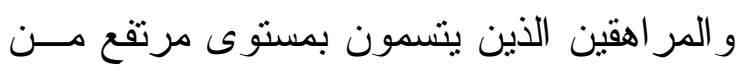

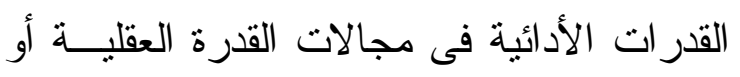

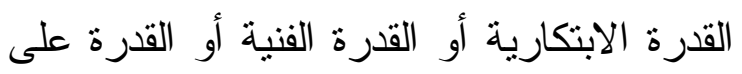
القيادة، أو يتسمون بوجود قدر ات مرتفعة فــى 
في منظمة معينة. أما الثاني فيهتم بالإستخدام أو النطبيق المقـصود لمجموعــة مــن الأفكـار

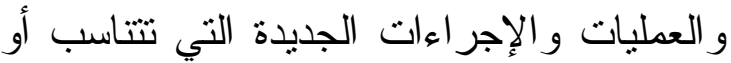
تتسق مع الوحدة أو البيئة التي تستخدم أو تطبق فيها. צ- الطالب المتفوق Creativity: هو المتميز سواء فى الذكاء أو التحــصيل الدراسـى لهى

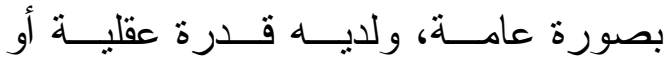

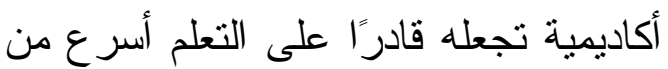

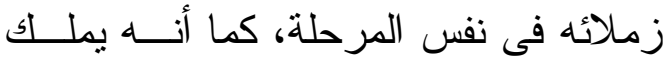

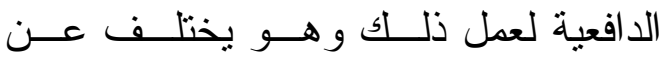
الموهوب و الذى يظهر مستوى أداء أو لديه استعداد ومتميز فى بعض المجالات التـى

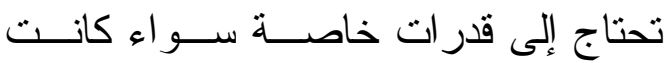
علمية "رياضيات-طبيعة-كيمياء-هندسـة" أم فنية "رسم-موسيقى -تمثيــلـل أم عمليـــة

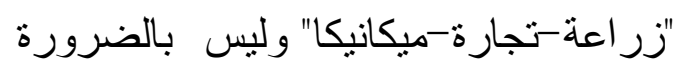
أن يتميز هذا الفرد بمستوى مرتفــع مــن

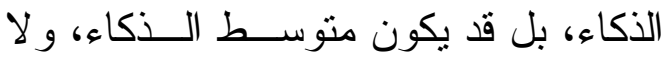
يشترط أيضاً أن يتميز بمستوى تحسصيل فئل

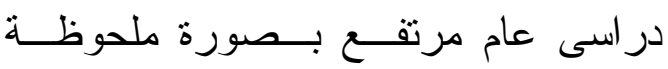

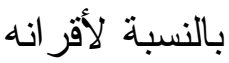

ثانيًا: تطور رعاية الطلاب المتفوقين في مصر يرجع اهتمام مصر بالمتفوقين إلى عــام

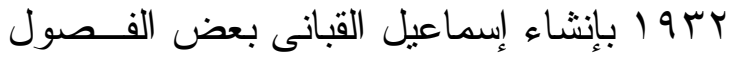

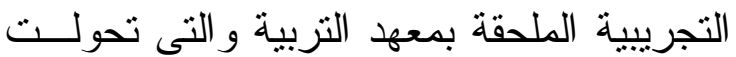

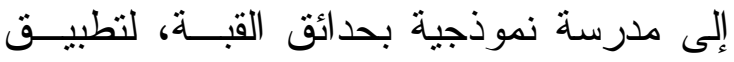
مبادئ التربية الحديثة ومر اعاة الفروق الفردية.
التفكير ويتميز الطالب المبدع بالتفكير الناقد ، و الرغبة فى التجديد و التغيير ، و اســتـعداد

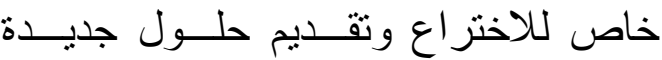

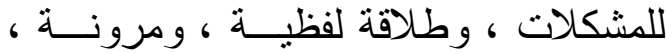
وتقديم أفكار أصيلة.

و الجامع بين هذه التعريفات هو اتفاقهــا على بعض القدر ات العقلية المميزة للموهــــين لهاهين مثلك؛ القدرة على التأمل، الثغف للتعلم، قدرات

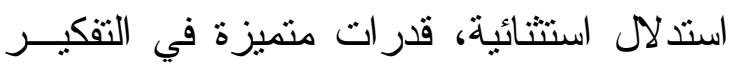

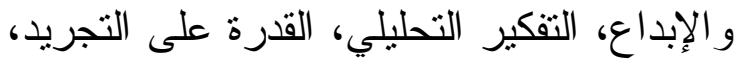

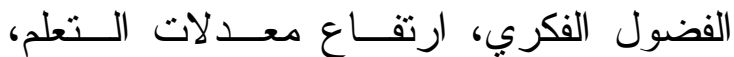
و الخيال الخصب (Cross, 2010, 7). ه- الابتكار Innovation : إن الابدكار في اللغة يعني ابتداع الثيء، ابتكر الــشئ أبي

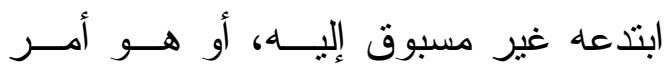

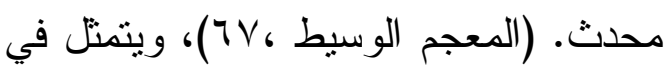

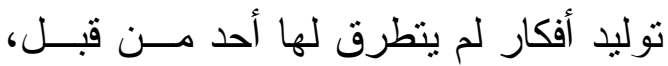

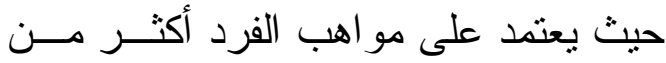
اعتماده على إيحاءات ومؤثر ات خارجيــة، ويري البعض أن الإبداع يعتبر سببا فئسي

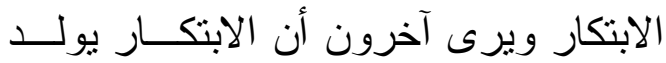

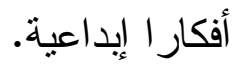

و الابتكار و الإبداع مفهــومين متــــر ادفين

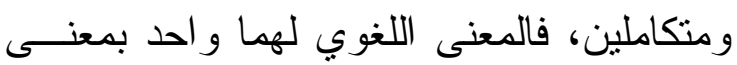
الإنثاء على غير مثال ســابق أو الاســتحداث

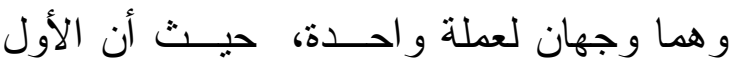

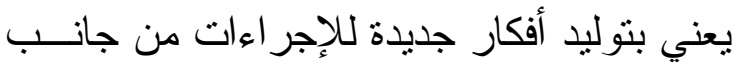

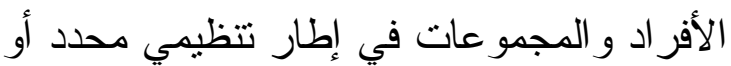


ومن منطلق تحقيق مبدأ تكافؤ الفـرص

التعليمية بين البنين و البنات أنشئت أول مدرسة ثانوية للمتقوقات عام 90 V بمدينة حلوان أسوة بمدرسة المتفوقين للبنين بعين شمس، وتعدـل بنفس الثروط و الأهداف المطبقة بها. ثم انتقل الاهتمام بالمتفوقين إلى بعـض لهـ

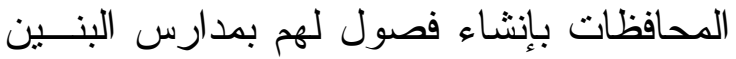

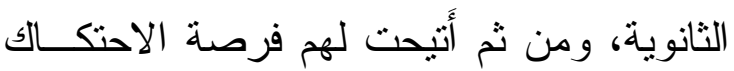

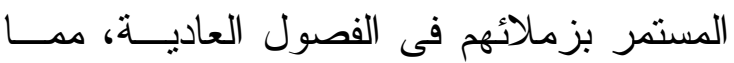

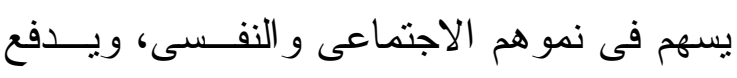

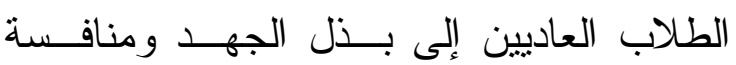

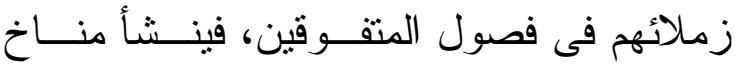

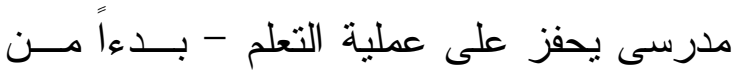
العام الدراسى • •9 1، وكان من بين شروطها

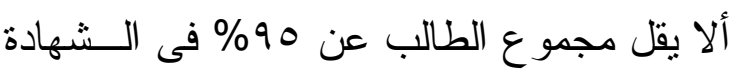

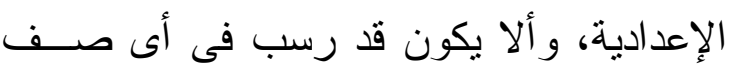
من صفوف المرحلة الإعدادية.

وفى عام ال197 صدرت لائحة لمدرسة

المتفوقين تتكون من إحدى عشر مــادة تبـين

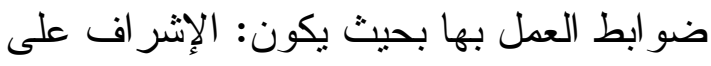
المدرسة تتو لاه هيئات متخصــصة مثــل إدارة البحوث الفنية و المشرو عات بـــوز ارة التزبيــة

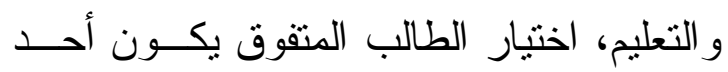
خمسة يتم اختيار هم من بين العشرة الأو ائل بكل

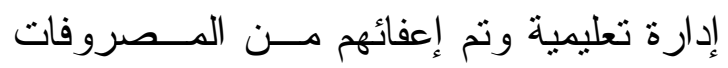

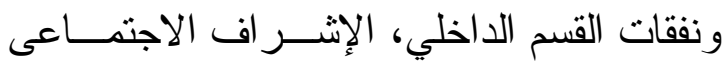

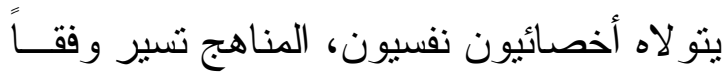

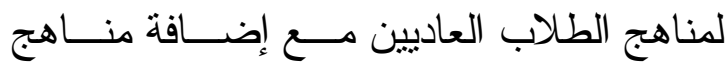

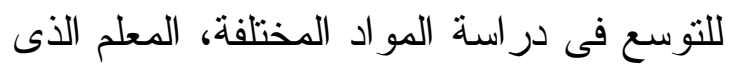

وبعد قيام ثورة يوليــــ 90 ام حظيــت

فئات ثلاث من الموهوبين و المتفوقين بالر عاية

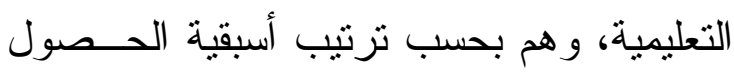

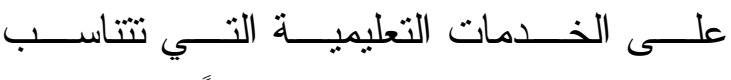
و واستعداداتهم: المتقوقون تحصيليا ، و المتفوقون

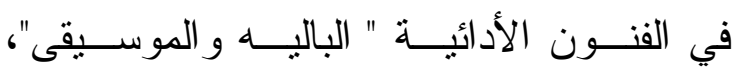

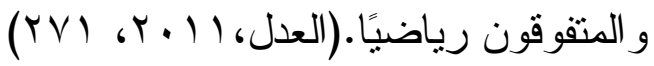

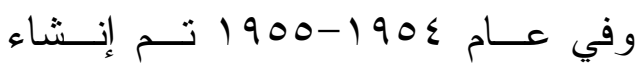

فصول للمتفوقين بمدرسة المعسادي الثانويــة النموذجية للبنين وكانت تقبل الخمسة الأو ائـلـل

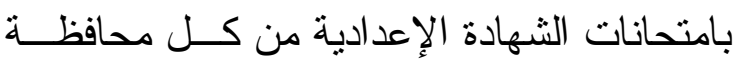
و استمر هذا الوضع حتى تم بناء أول مدرســـة للمتفوقين بعين شمس عام •و97 الغير اســمها إلى مدرسة المنقوقين التجريبية النموذجية للبنين

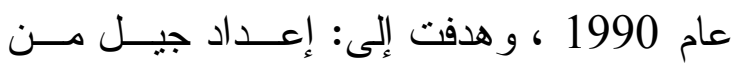

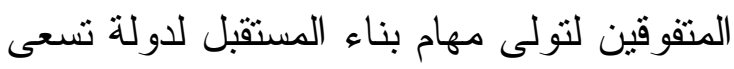

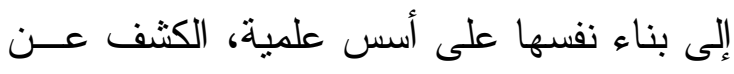

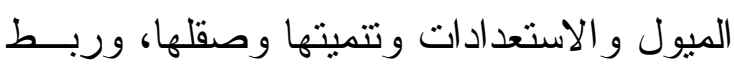

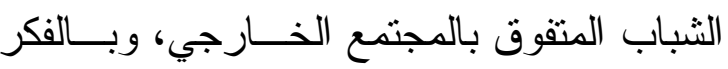
و العمل الوطنى. وبذللك تميزت هذه المدرسة بمجموعـــة

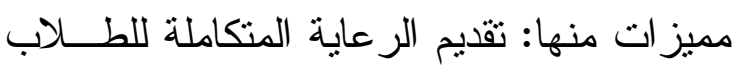

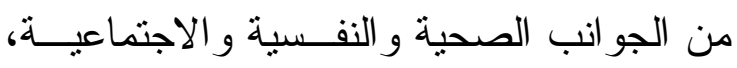
بعض البرامج الإضافية المرتبطة باستعداداتهم

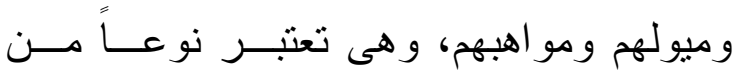

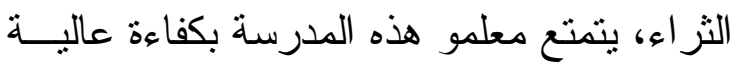

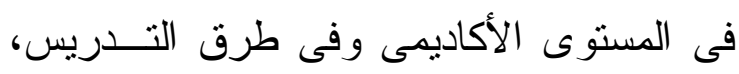

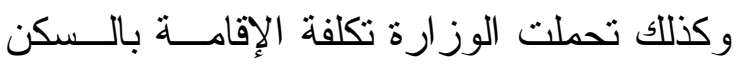
الداخلى كاملة وكذلك ملابس الزى المدرسى. 
ويتم قبول الطلاب فـى هــــه الفـصول

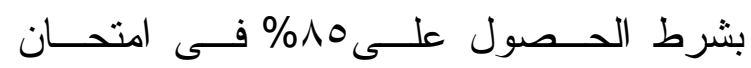

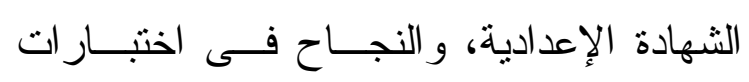

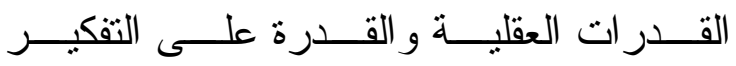

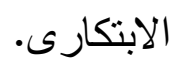

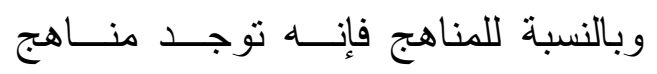

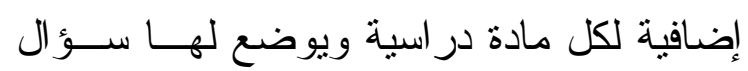

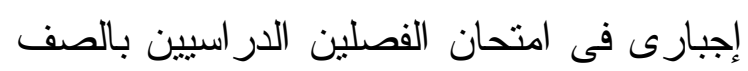

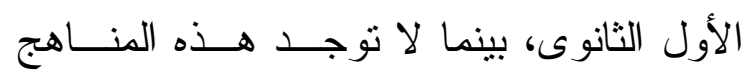

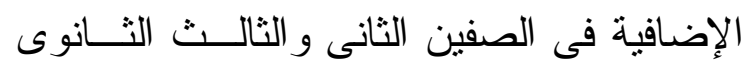

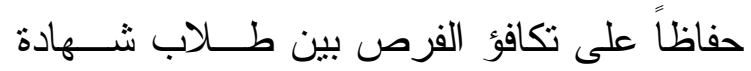

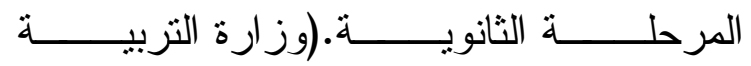

$$
\text { و التعليم، (1919 ) }
$$

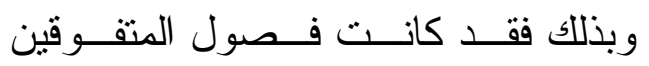
بالمدارس الثانوية العامة تندرج تحــت نظــام

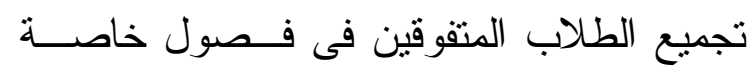
طول الوقت، وتسير مناهجها وفــق المنــاهج

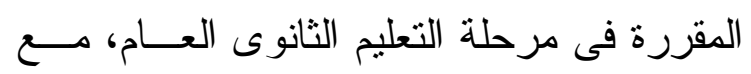

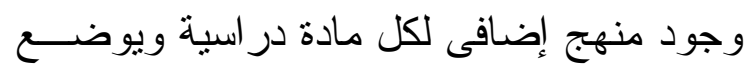
لهذا المنهج الإضافى سؤال إجبارى فى امتحان

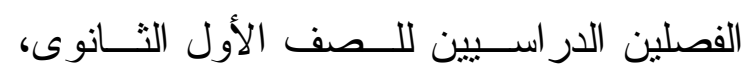

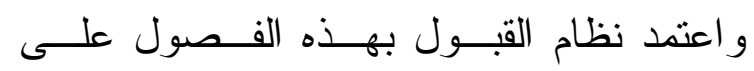
التحصيل الدر اسى و الذكاء و القدرة على التفكير

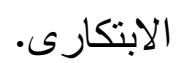

وفى عام 1919 نم تشكيل اللجنة العليــا

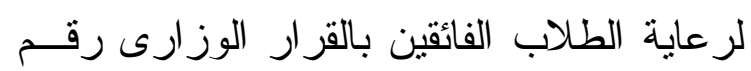

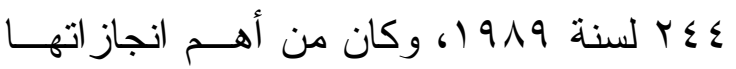
إعداد مشروع مر اكز الفائقين، لتجميع الطلاب لهن اهن
يقوم بالتدريس للمتفوقين يكون من المتميـزين

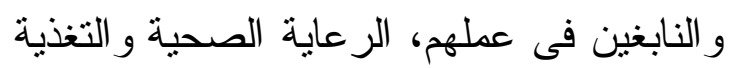
مجاناً للطلاب، مع تخصيص ميز انية مسستقلة لهذه المدرسة من ميز انية وز ارة التربية و التعليم.

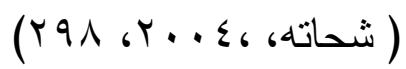

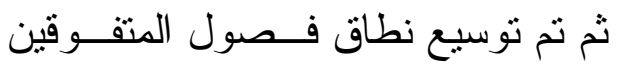
ليشمل كل المحافظات بصدور القرار الوز ارى بطون

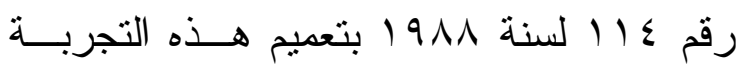

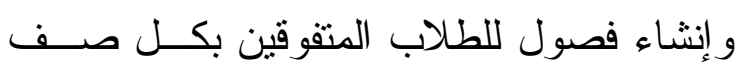

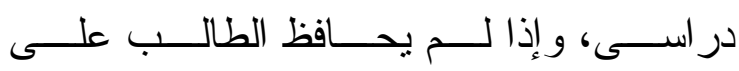

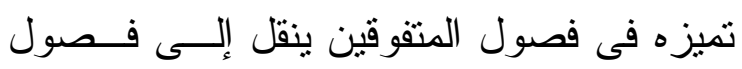
العاديين.

\section{وهدفت فصول المتفوقين إلى:}

- الاهتمام بر عاية الطلاب المتفوقين.

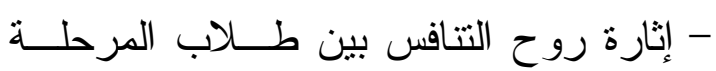
الثانوية و العمل على اللحاق بهذه الفئة.

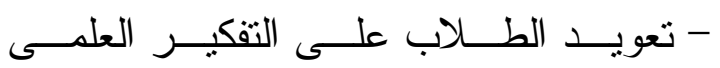

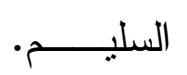

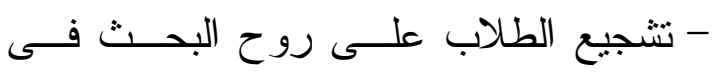
المر اجع خارج الفصل من خلال المكتبــات الفات

$$
\text { المدرسية. }
$$

- توثيق الـــلة بــين منطلبــات الطــلاب المتفوقين وبين الدر اسة الجامعية.

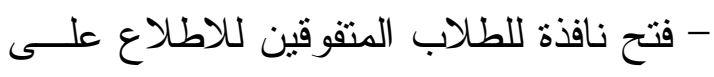

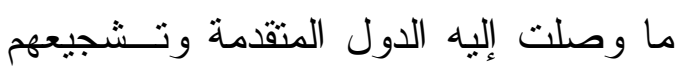
على الاثتر الك فى المسابقات الدولية.

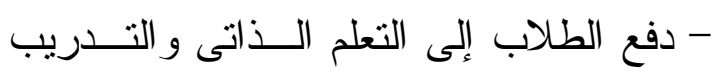

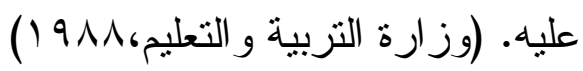


- إعــــاد جيــل مــن العلمـــاء و المفكـــــن و المختر عين و المبدعين ومسن ثــم فــإن

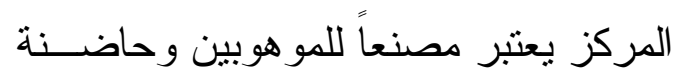
لعلماء المستقبل.

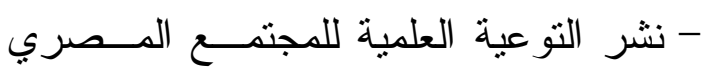

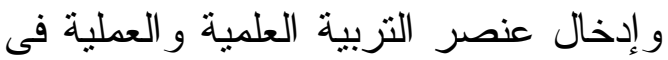

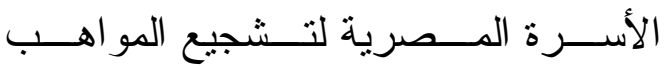
و القدر ات الفردية المتميزة. - تعميق الانتماء من خلال التركيز على دور

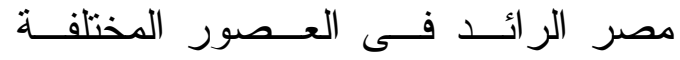
الفرعونية و القبطية و الإنسلامية و العـصر العرد الحديث. - التأكيد على معنى التو اصل بالثركيز علــى سير العلماء و إنجاز اتهم من كافـــة أنحســاء

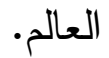
- إعادة تدريب المعلمـين لمو اكبـــة الفكــر الاستكثافي في التعليم من خلال التــدريب

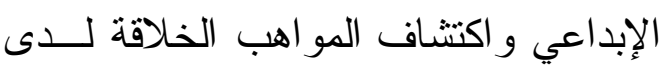
المعلمين باعنبارهم المسئولين الأوائل عن تطوير العملية التعليميــة.(وزارة التربيـــة

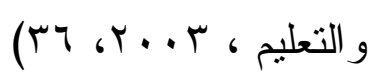

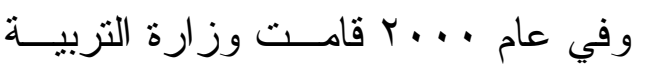
و التعليم بإنشاء إدارة لاكتشاف ورعاية الطلاب

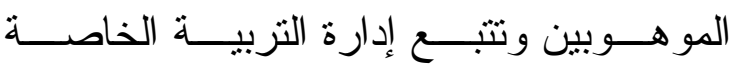
بالوزارة، وتم إنشاء هذه الإدارة بناء على قرار

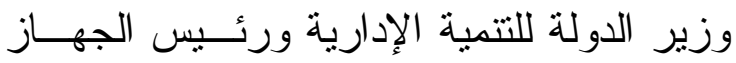

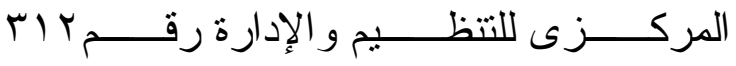

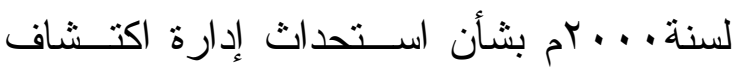

الفائقين من المدارس المختلفة فى مكان و احسد، يتلقون فيه العديد من ألوان الرعاية الاجتماعية

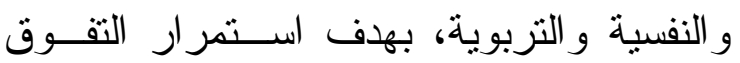
و إبر از المو اهب و القدر ات لدى الطلاب، وتعمل هذه المر اكز لمدة ثلاثة أيام فى الأسبوع، ويقوم

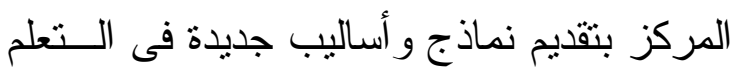

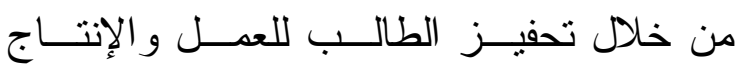

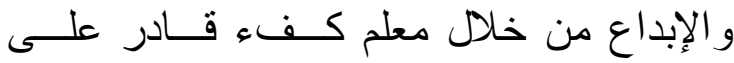
مساعدتهم على الإبداع و التقوق و الإنتاج.

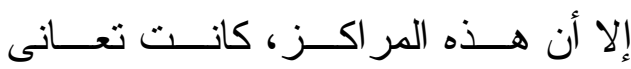
مشكلات منها: ليس لها بر امج خاصة لرعايــة

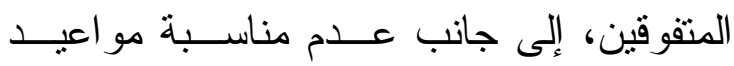

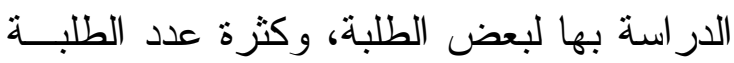

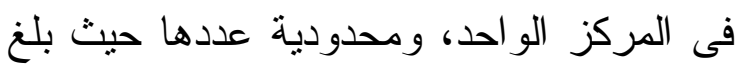
؟ب مركزًا على مستوى الجمهورية لمراحـل

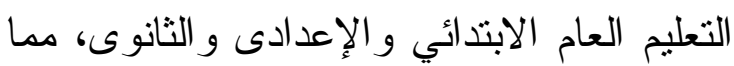
جعل الوزارة تفكر فى إنشاء مر اكــز لرعايـــة

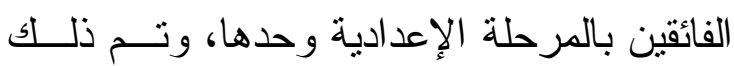
عام 1990 تحت إثـــر اف مكاتـب الخدمـــة الخها الاجتماعية المدرسية.

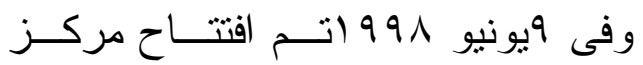
سوزان مبارك الاستكثنافي للعلوم الذي أنسشأته

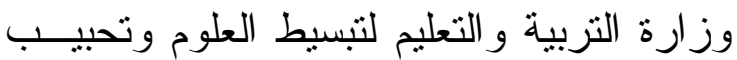

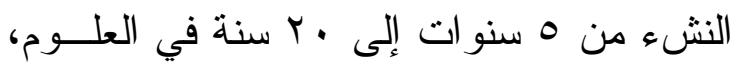
وتحقيق الأهداف التالية: - تكوين الثخصية العلميــة للأطفــال عـن الافن طريق نشر حب العلوم. 
تصور للأنشطة التـى بمكـن أن تـشبع حاجات الدو هوبين وكيفية رعايتهم.

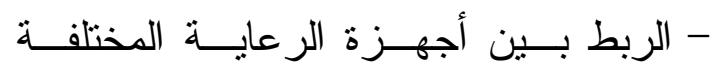

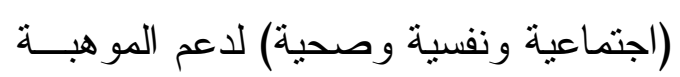
و إثراء التفوق.

- ابتكار أنشطة هدرسية تساعد على اكتثاف

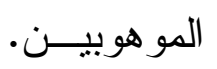

- متابعة تتفيذ القرارات التى تـصدر عـن المؤتمر ات المرتبطة بالمو هبة.

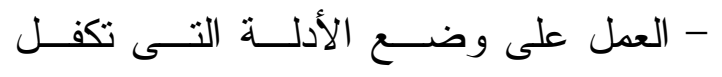

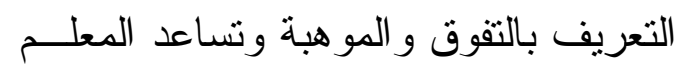

$$
\text { على تلبية حاجاتها. }
$$

- التعاون مع المر اكز البحثية لوضع البرامج البها.

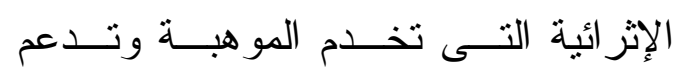

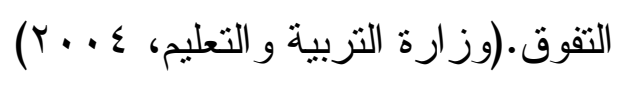

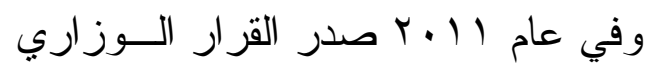

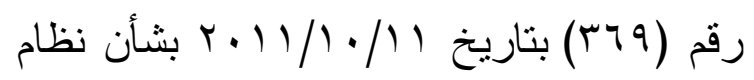

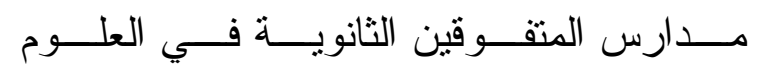

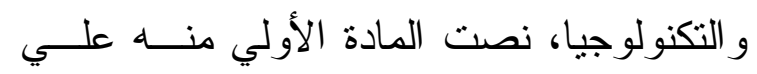
إنثاء مدارس المتفوقين في العلوم و التكنولوجيا

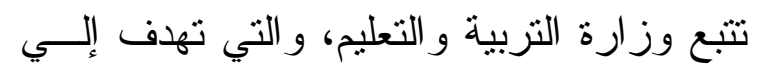

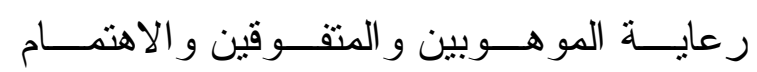
بقدر اتهم، تدريس المناهج المنطورة في العلـــوم

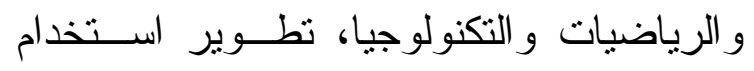
أساليب تكنولوجيا المعلومات لتطــــير العمليـــة

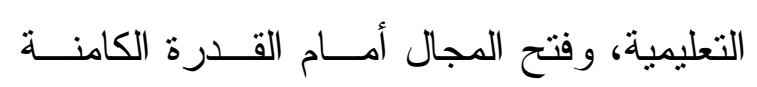
الإبداعية للطلاب.

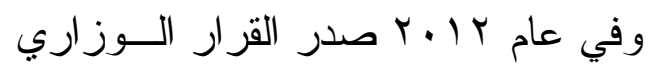

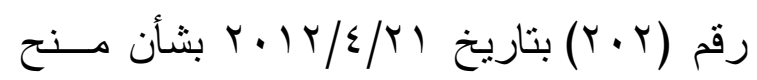

ورعاية الموهوبين لإعداد جيل مـن العلدـاء و المبدعين و المفكرين و الفنانين.

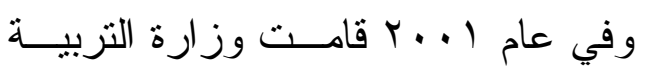

و التعليم- في إطار تشجيع المتقوقين - بتصميم بطاقة لمتابعة أطفال الروضة و الصفوف الثناث

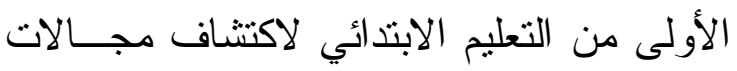
التميز الدختلفة لدى الطفل ، و اقترحت الوسائل

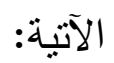

- إعـــداد اختبـــار ات خاصــــة لاكتهــشاف الموهوبين.

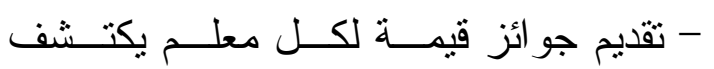
مو هوبا من تلاميذه. - إجر اء العديد من المسابقات (منــاظرات من اتهات

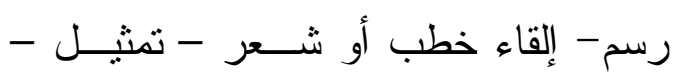
تأليف قصص موسيقى).

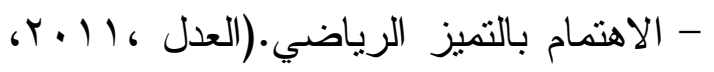
(rV

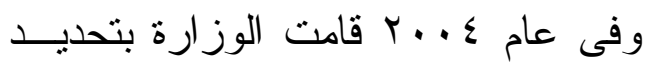
اختصاصات إدارة اكتثاف ورعاية الموهوبين على أن تمارس الاختـ صـاصات و المـسئوليات

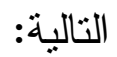
- متابعة الاتجاهات الحديثــة فـى أســاليب رعاية المو هوبين و إعداد الأطر التى تكفل تحقيقها بالمدارس المصرية.

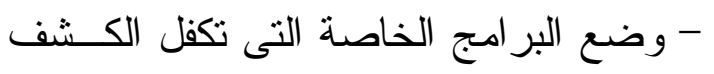
المبكر اللمو هبة (عند الالتحاق بالمدرســة) ونشر ها على المديريات.

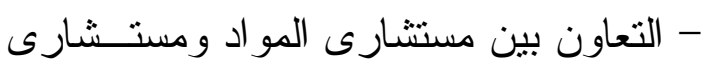

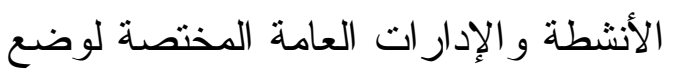


و التكنولوجيا في المحافظات التالية: "الإسكندرية بمنطقة برج العرب، ومحافظة أسيوط بمدينــة أسيوط، والأقصر بمدينة طيبة، ومحافظة البحر الأحمــر بالغردقــة، ومحافظــــة الإنــــاعيلية

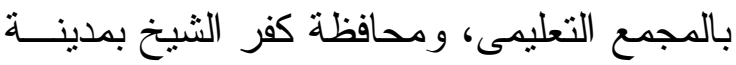

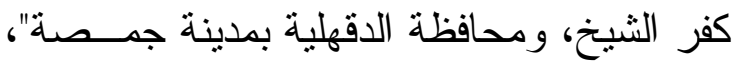

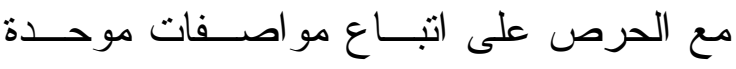
لجميع مدارس المتفوقين.

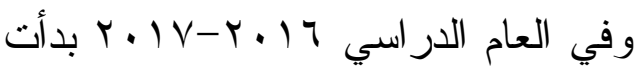

الار اسة في مدارس المتفــــين فــي العلــوم و التكنولوجيا في محافظتي "الغربية و المنوفية" وبعد هذا الاسـتـعر اض لو اقــع رعايــة

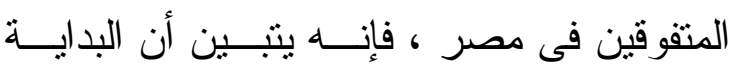
كانت بوجود مدرسة للمنقوقين من البنين بعـين

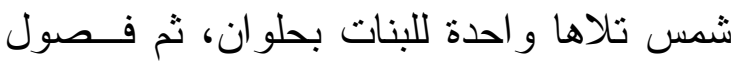

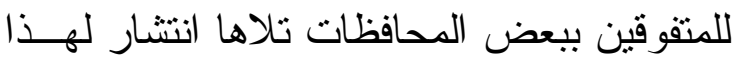

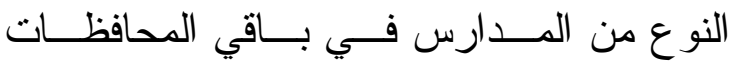

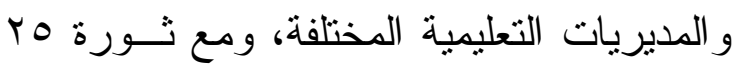

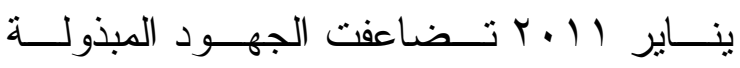
و المؤتمر ات و الخطط الإصلاحية من قبل الدولة و الوزارات المختلفة لا ســيما وزارة التزبيــة

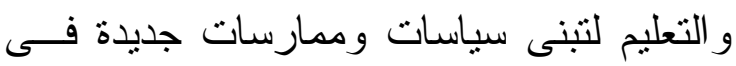
مجال رعاية المتفوقين بإنشاء مدارس المتفوقين للعلوم و التكنولوجيا STEM ، وتحديد أهـــافها

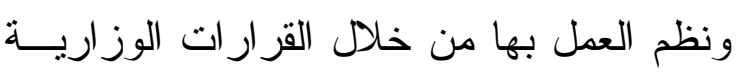
السابقة و التي تمخضت عن إنثاء مدرسة للبنين في أكتوبر ، تلاها مدرسة للبنات في المعادي ثن

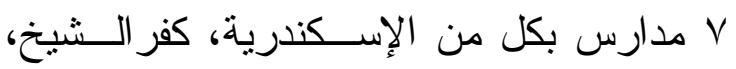

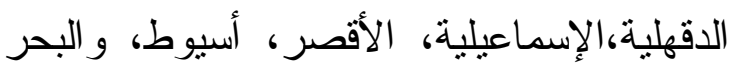

شهادة الثانوية المصرية في العلوم و التكنولوجيا من مدارس المتفــوقين الثانويــة فــي العلــوم و التكنولوجيا، وهـي معادلـــة فــي مناهجهـا للصفوف الــثلاث بالــشهادة الثانويــة العامـــة المصرية، كما صدر في نفـس العــام القــرار

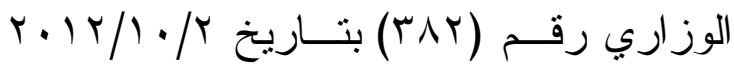

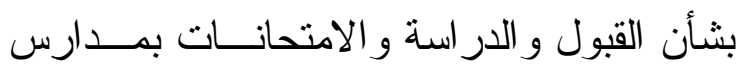
المتفوقين الثانوية في العلوم و التكنولوجيا.

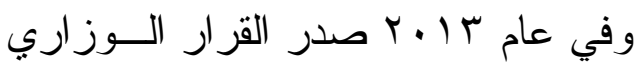

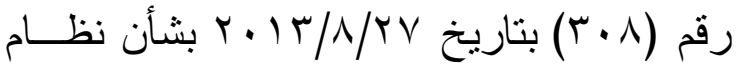

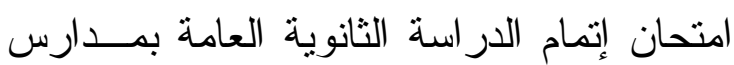
المتقوقين الثانوية في العلوم و التكنولوجيا.

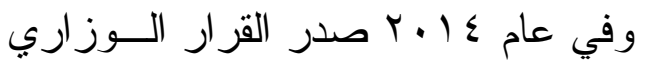

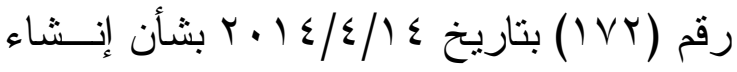
وحدة مدارس المتفوقين "STEM" في العـــوم

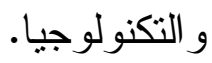
وفي عام 10 .ب صدر القرار الــوزاري

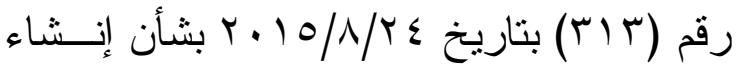
اللجان الفرعيـة لــدعم مــــارس المتفــوقين

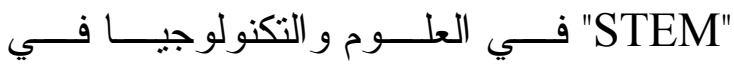
محافظات الجمهورية. وقد بلغ إجمـالي عــد المـــارس 11

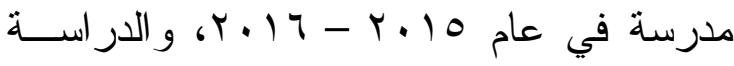

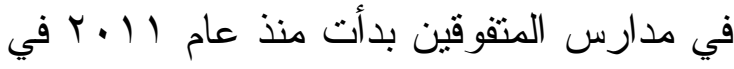
مدرسة المتفوقين في مدينة السادس من أكتوبر بمحافظة الجيزة، تلاها إنثاء مدرسة المتفوقات بزهر اء المعادى بمحافظة القاهرة عام Y Y ب. Y.،

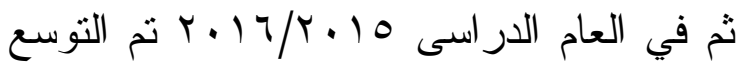
في إنشاء سبع مدارس المتقوقين فــي العلــوم 
أنتشئت مدارس المتفــوقين فـــي العلـــوم

و التكنولوجيا STEM بمصر بــصدور القــرار

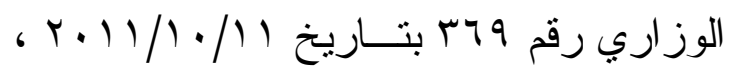

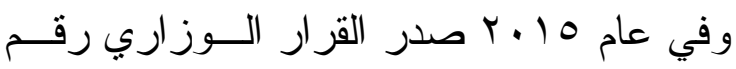

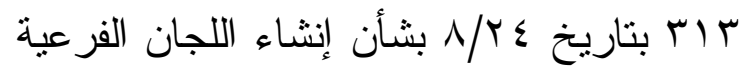

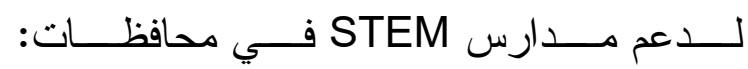
الإسكندرية، الدقهلية، كفر الثيخ، الإسماعيلية،

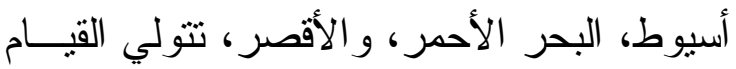

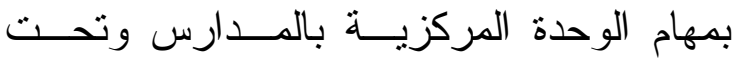

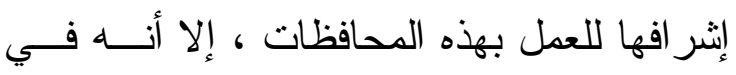

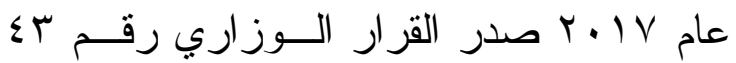
بتاريخ / ب لتعديل أماكن إنثاء اللجان الفرعية لاعم مدارس STEM في كل المحافظات الني بها مدارس للمتفوقين في العلوم و التكنولوجيا. شروط القبول بمدارس STEM

حددت المادة السادسةمن القرار الوزاري

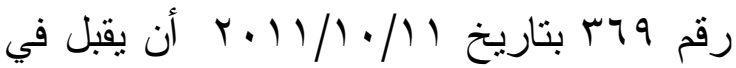

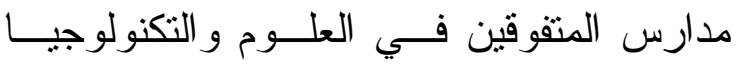
بمصر من خريجي مرحلــة التعلــيم STEM

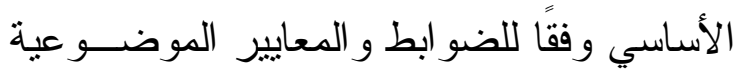

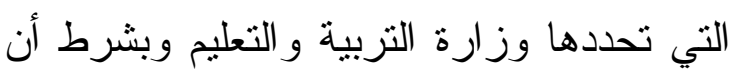
يكون متفوقًا ويحقق مستويات الأداء المطلوبــــة وزئة في اختبار ات القبول.

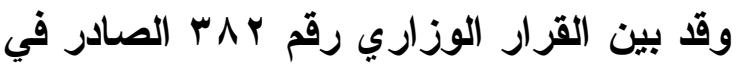

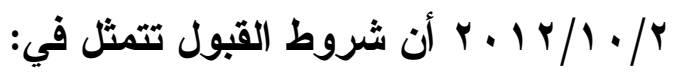
ا ـ ألا يقل مجموع درجات الطالب في امتحان

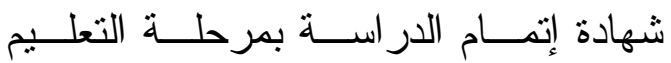

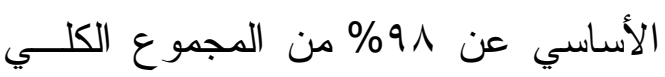
للدرجات.
الأحمر وبذللك صار عددهم نسع مدارس، وفي

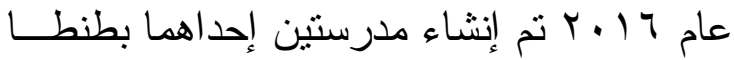
و الأخري بسرس الليان ليصل عددها إلي إحدي عشر مدرسة. ثُالثًا: تعليم منير تقوم الحكومات في جميع أنحـــاء العـالم

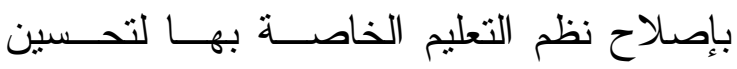

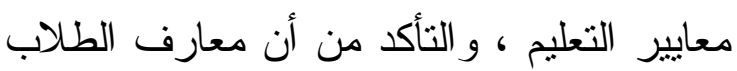
ومهار اتهم تنتاسب بشكل إيجابي مــع معسـارف

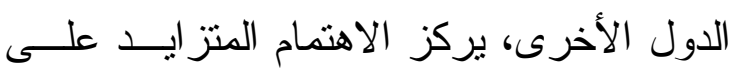

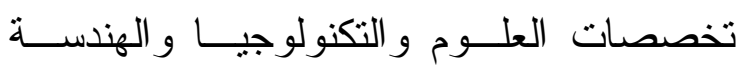

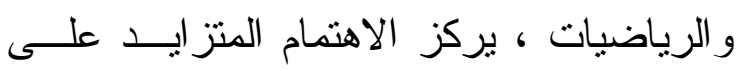

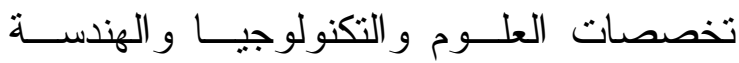

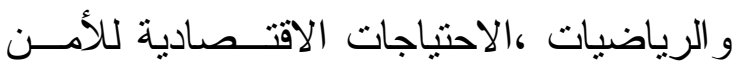

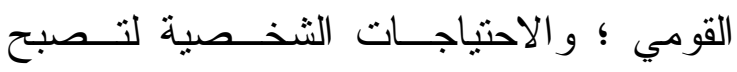
مو اطنة منتجة ومثمرة ومعرفــة ذات الـصلة لتغير توقعـات اقتـصـادات القــرن الحســادي و العشرين من خلال تعزيز المعرفة والمهارات و القيم المتعددة التخصصات ذات الصلة بالحياة الحقيقية العلمية و الاقتصادية للبلد و الحفاظ عليه

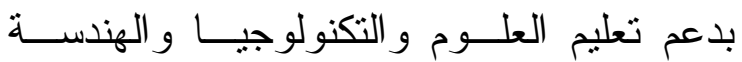
و الرياضيات. (Sumen \& Calisici, 2016 ) أن تعليم STEM مهم لأنه بـسـهم فـي هي

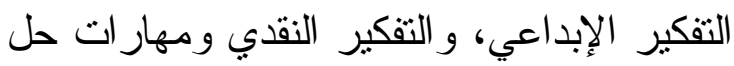
المشكلات ، ويتيح التعلم من خلال الممارســة ولفئة

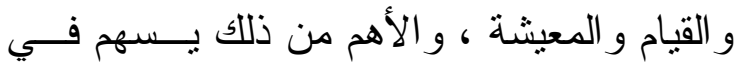

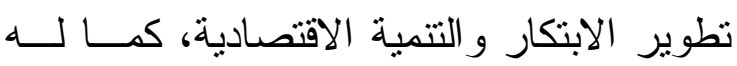

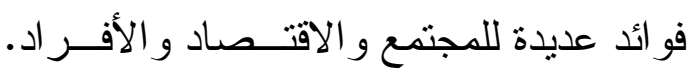
(Yıldırım \& Turk, 2018) 
الحادية عشر من القرار الــــز اري رقـم rيـ

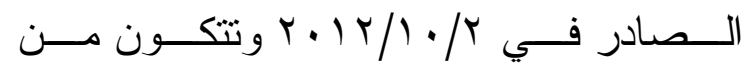
عضوية: رئيس الأكاديمية المهنيــــة للمعلمـين، رئيس الإدارة المركزية للتعليم الثانوب، ممثنـل لمجلس إدارة المدرسة، مستشار المادة، مسدير المدرسة ورئاسة رئيس قطاع التعليم العام.

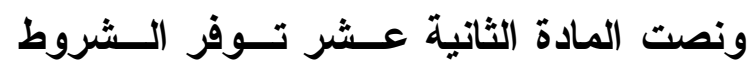
الآتية فيمن يتم اختيارهن: ا. سبق لهم السفر بالخارج في بعثات تعليمية

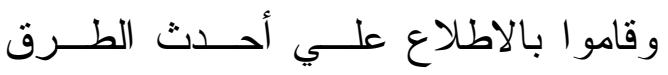

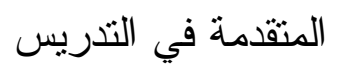
r. من الحاصلين علي درجة الماجسستير أو لورين الدكتور اه من المدرسين العاملين في وزارة

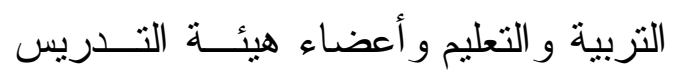
بالجامعات المصرية r. من ذوي الكفاءة المتميزة في التتريس من بله المدارس التجريبية ع. المتخصصون في اللغة الإنجليزية ويفضل من اجتاز اختبارات المستوي فــي اللغـــة الانجليزية

أهداف مدارس STEM

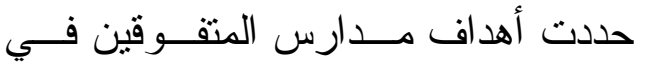

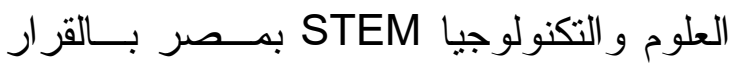
الوز اري رقم 97؟ ، و الذي تتص مادته الثانية علي أن أهداف هذه الددارس تتمنل في: 1. رعاية الموهوبين و المتفوقين و الاهتمام

$$
\text { بقدر اتهم }
$$

r. تـريس المناهج المتطورة فـــي العلــوم

$$
\text { و الرياضيات و التكنولوجيا }
$$

r. أن يكون الطالب حاصثًا علــي الــدرجات النهائية في مادتين علي الأقل من مـــواد: اللغة الإنجليزية، الرياضيات، و العلوم.

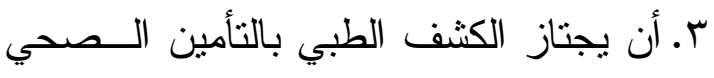
في الإدارة التابع لها المدرسة.

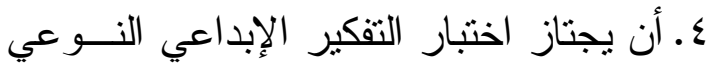

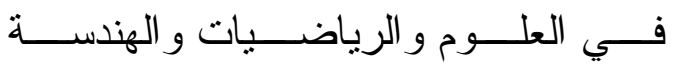

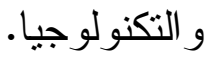
ه. أن يجتاز اختبار مستوي الذكاء. 7. أن يجتاز المقابلة الثخصية بنجاح.

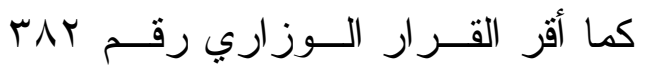

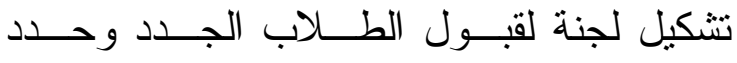
اختصاصاتها بمادته الر ابعة، كما بين تـشكيل

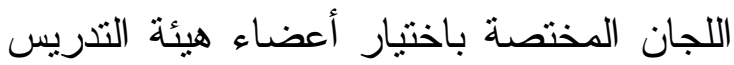

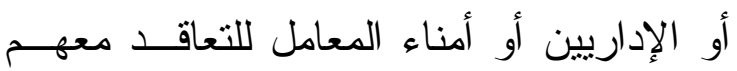

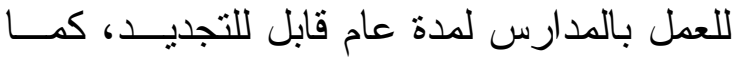
حدد تشكيل اللجنة المعنيــة باختيــار مــديري

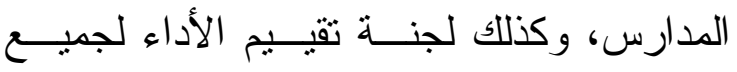

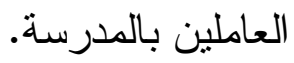
ويشترط للاستمر ار في هــذه الهـــارس تحقيق الطالب نجاحًا متميزًا في در استه -كمــــا

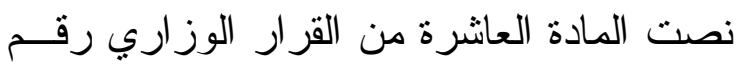

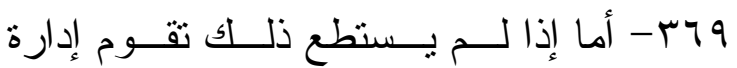

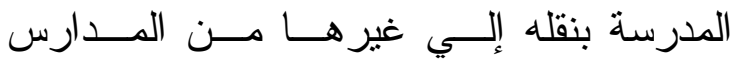
التجريبية أو الحكومية. شروط اختيار المعلمين بمدارس STEM

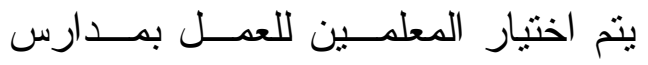
المتفوقين عن طريق الإعلان بنظام التعاقد لمدة عام قابل للتجديد من خلال لجنة تتكل بالمـادة 
و • 1\% أداء الطلاب أثناء العام الدراسي، ولكي

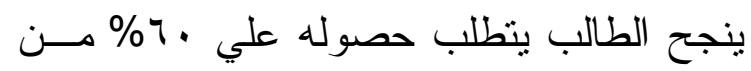
الدرجة النهائية.

ويتم تحديد نظام امتحان شــهادة إتـــام

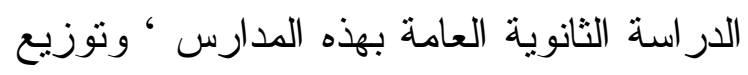

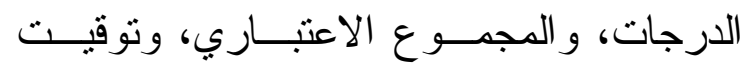

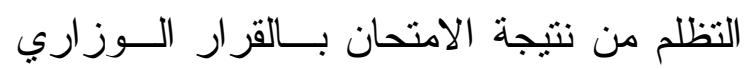

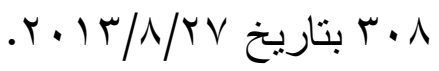

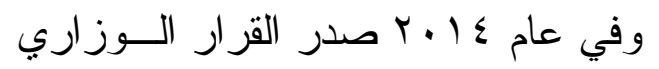

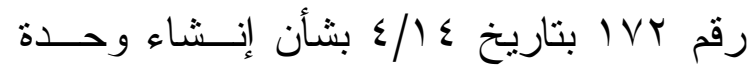

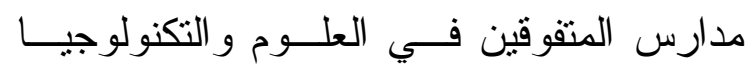

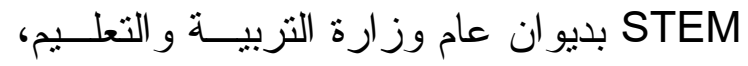

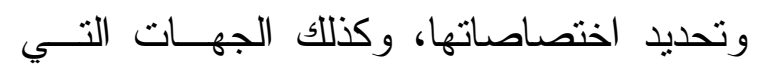

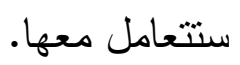

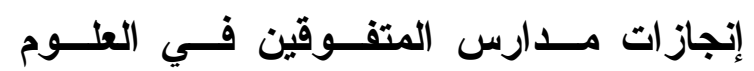

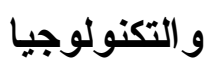
تسعى مدارس STEM في مصر إلي:

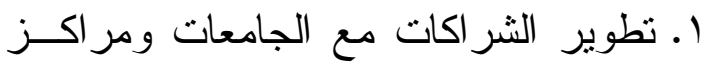
البحوث العلمية من أجل التطوير و التدريب

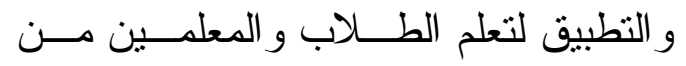

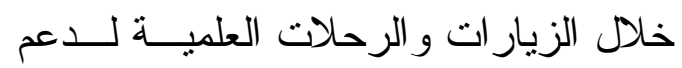
الأنشطة المرتبطة بالمشروعات البحثية.

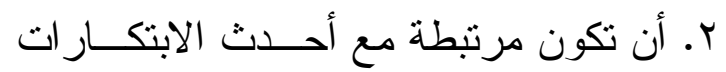
و القضايا البحثية في ثقافــة مــدى الحيــاة و العمل كفريق مع الطلاب و المعلمين.

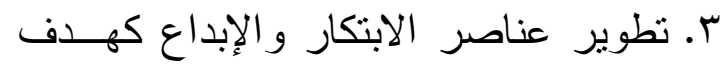
أساسي وتعظيم دور العلوم و الرياضــيات

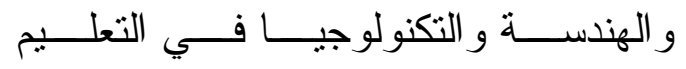

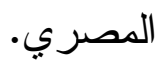

r. تطوير اســتخدام أســاليب تكنولوجيــا المعلومات لتطوير العملية التعليمية

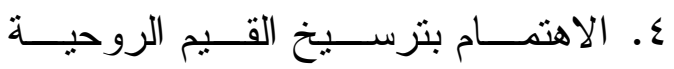
و التزبوية وتعميق قيم التسامح و الانفتاح علي العالم ه. فتح المجــال أمــام القــدرة الكامنـــة الإبداعية للطلاب ويكون لكل مدرسة مجلس إدارة يختص لإبل

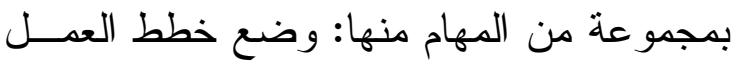

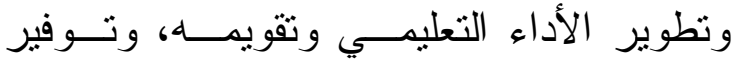
الوسائل التكنولوجية المنطورة الادئ STEM مناهج مدارس

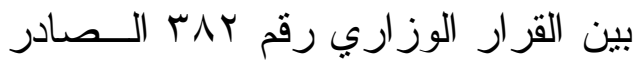

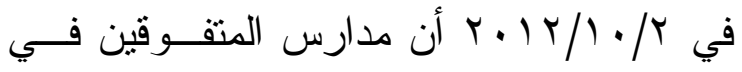
العلوم و التكنولوجيا مدارس ثانوية ذابل ذات منــاهج

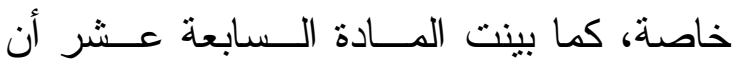
الدر اسة بهذه المدارس تقـوم علــي اســتخدام طريقة المشروعات والوحدات التكاملية القائمة علي البحث و الاستقصاء عبر المواد الدراســية

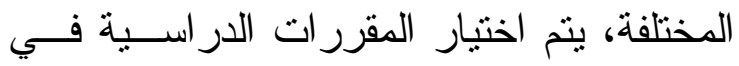
إطار المعايير القومية والمعايير العالمية لنظــام

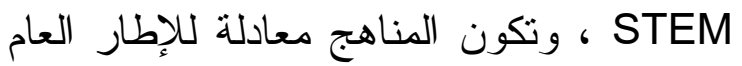
للمناهج في المرحلة الثانوية العامة STEM التقويم في مدارس بينت المادة الثالثة و العشرون من القرار

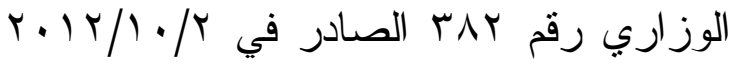
أن تقويم الطلاب في كل مادة در اسية يتم مـن

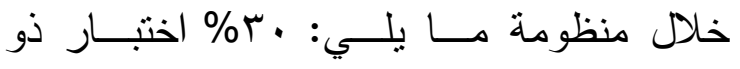
مواصفات خاصة، ، \%\% تقييم المـشروعات، 
V. رعاية المتفوقين في العلوم و الرياضـيات و الهندسة و التكنولوجيا و الاهتمام بقــدر اتهم

ليكون لليهم القدرة علي الإبداع و التفكيــر النقدي.

ولطــلاب مـــارس STEM إنجــاز ات

عديدة تم معرفتها أثثـــاء الزيـــار ات الميدانيـــة

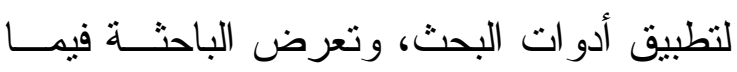

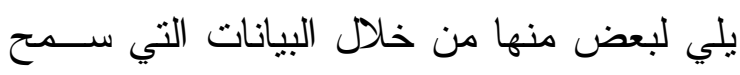

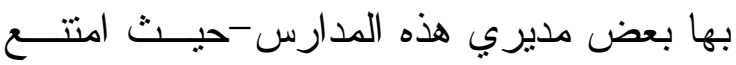
بعض المديرين عن إعطاء هذه البيانات مباشرة

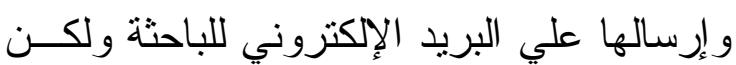

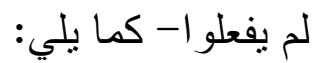

ع. توفير الدعم الفني و المالي للــتعلم القــائم على الطالب الذي بركز على المشروعات الاستقصائية و العمل التعـاوني و إكــسابهم

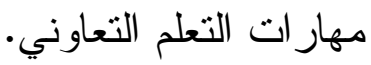

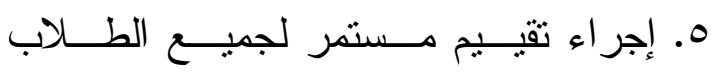

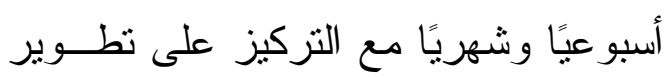

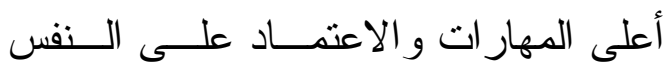
وتحفظ نتائج الثقييم في ملف خاص بكــل

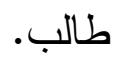
T. يتم تقييم الأداء لجميع العاملين نهاية كـلـ

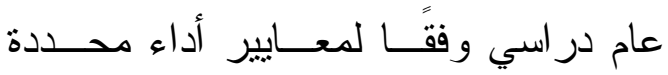
للمحافظة علي مستوي عــال مــن الأداء

للجميع.

مدرسة المتفوقين في العلوم والتكنولوجيا بالدقهلية

\begin{tabular}{|c|c|c|}
\hline اسم المسابقة & اسم الطالب & P \\
\hline UAMS - EISTF - Blastoff - ISEF & سيف آسر فوزى راضى & 1 \\
\hline ISEF & لبني عبدالغتي عبدالعزيز & 2 \\
\hline EISTF - ISEF - RICOH - SYB - IDEAS & \multirow[t]{2}{*}{ أسماء أحمد سليمان } & \multirow[t]{2}{*}{3} \\
\hline $\begin{array}{l}\text { Sمابقة مشاريع بكلية العلوم جامعة المنوفية ISEF - NASA } \\
\text { Space APPS }\end{array}$ & & \\
\hline ISEF - American Meteorological Society & مروة إسماعيل عبد الحميد علي يوسف & 5 \\
\hline ISEF - NASA Space APPS - Blastoff & أحمد ممدوح الصغير & 6 \\
\hline مسابقة مشاريع بكلية العلوم جامعة المنوفية & عايشة محمود أحمد سيدأحمد & 7 \\
\hline Robot Challenge & سميف آسر فوزى راضى & $\wedge$ \\
\hline ISEF ( Cairo) & أسماء كرم & 9 \\
\hline
\end{tabular}


مدرسة المتفوقين في العلوم والتكنولوجيا بكفر الثيخ

\begin{tabular}{|c|c|c|c|}
\hline اسم المسابقة & اسم المشروع & اسم الطالب & r \\
\hline 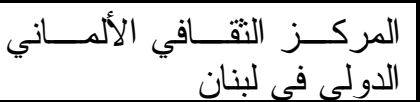 & دكتور اه فخرية & أمل السيد الصعيدى & 1 \\
\hline STEM Market2017 & Wind Tracker & محمد سعد عبد الفتاح & 2 \\
\hline STEM Market2017 & NO Morediabetes & هديل هشام آدم & 3 \\
\hline Creative Day & Doesn't Matter & رونيم حسام البطرني & 4 \\
\hline Creative Day & Dlue Dream Realized & دإيناء عبد النيا فايدر إبراهيم & 5 \\
\hline Creative Day & Solar Cell in New Vision & أمل السيد الصعيدي & 6 \\
\hline ISEF & Solar Cell In New vision & أمل السيد الصعيدي & 7 \\
\hline ISEF & for clean future & فاطوى الثناوي عطية الله & 8 \\
\hline ISEF & modification of poroblic trough & ريمنى طريف محمد سيد أحمد & 9 \\
\hline ISEF & combine mine & مي محسن لقمه الرييعي & 10 \\
\hline ISEF & The day after melanoma & هدير على أبو السعود & 11 \\
\hline ISEF & algae biofuel & رواب أحمد سلايقه & 12 \\
\hline ISEF & eco factory & محمد حسين الجندي & 13 \\
\hline ISEF & hydrogen fuel cell & شمر عبد العزيز بركات & 14 \\
\hline ISEF & algae biofuel & انجى رضا دربالة & 15 \\
\hline ISEF & harvesting waves energy & ابر اهمي محمد شرف ابو حمائه & 16 \\
\hline | ايسف الغربية & Smart P.T.S.C & أحمد عبدالباسط الثناوى & iv \\
\hline |نتل ايسف & $\begin{array}{l}\text { Special award for outstanding } \\
\text { acheivment }\end{array}$ & حسام حسن النجار & 11 \\
\hline مسابقة أكاديمية البحث العلمي & 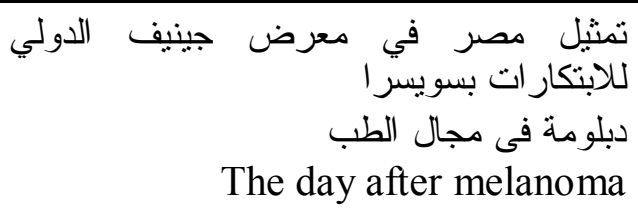 & 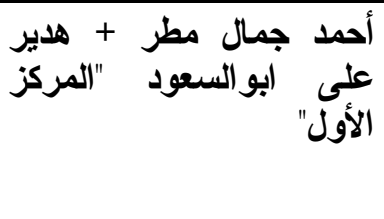 & 19 \\
\hline مسابقة أكاديمية البحث العلمي & 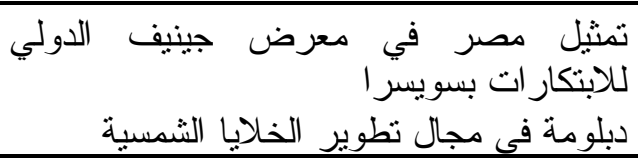 & "أمركز السبيد الصعيدي & $r$. \\
\hline 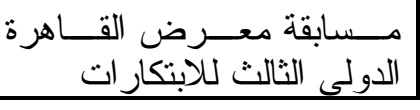 & أفضل مشروع علمي & أحمد جمال مطر & r) \\
\hline
\end{tabular}


د/هويدامحمود الإتهى

\begin{tabular}{|c|c|c|c|}
\hline اسم المسابقة & 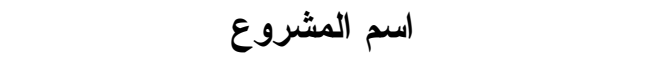 & اسم الطالب & b \\
\hline 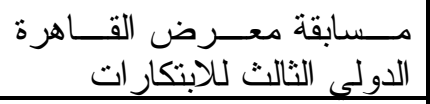 & 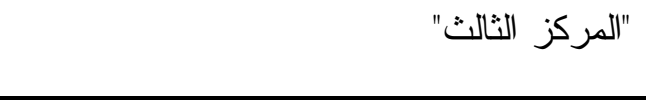 & هديرعلى ابو السعود & rt \\
\hline 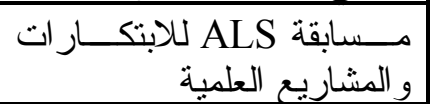 & "المركز الأول" على مستوى الجمهورية & هدير على أبو السعود & rT \\
\hline مسابقة شباب المختر عين & " الميدالية الذهبية" و المركز الأول & أمل السيد الصعيدى & $r \varepsilon$ \\
\hline 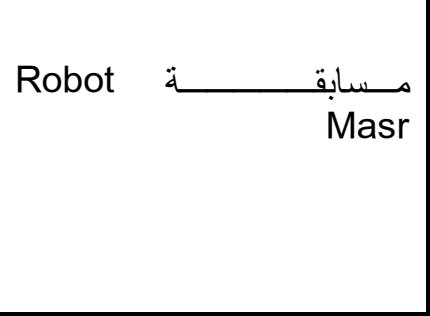 & " المركز الثالث" على مستوى الجمهورية & أروى عبدالله عبد القادر & ro \\
\hline Robot $\quad \begin{array}{ll}\text { Masr } \\
\text { Muسابة }\end{array}$ & " المركز الر ابع " على مستوى الجمهورية & 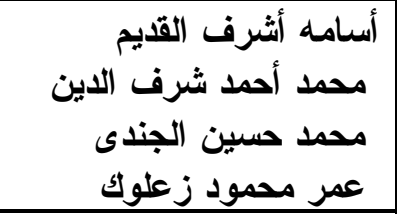 & ru \\
\hline 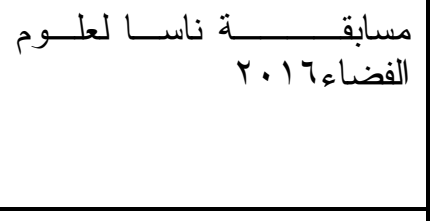 & "المركز الأول" على مستوى الجمهورية & عادل عمد فتحى الرحمن محمد يوسف بطرسم & rV \\
\hline مسابقة مصر تختز ع & sound makes more & هايدى هشام صقز & rᄉ \\
\hline مسابقة مصر تختز ع & microbial fuel cell & ياسمين على عبدالله & rq \\
\hline 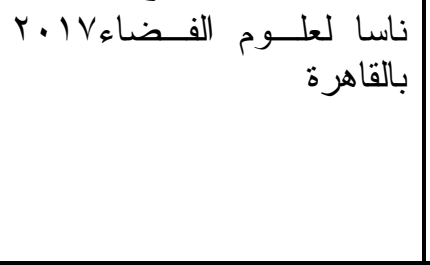 & $\begin{array}{l}\text { Challenge : where is the water } \\
\text { "planetary blues" }\end{array}$ & 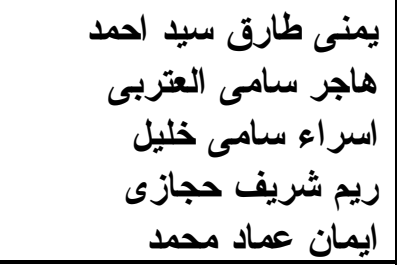 & r. \\
\hline 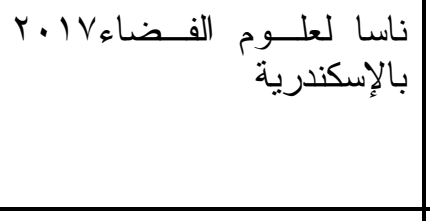 & $\begin{array}{l}\text { Category: warning danger } \\
\text { Ahead } \\
\text { في فرنسا Robotics التصعيد لنهائى مسابقة }\end{array}$ & 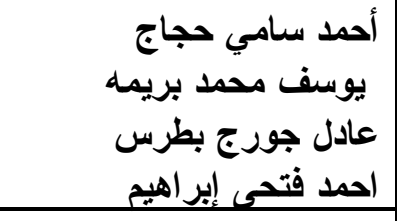 & M \\
\hline 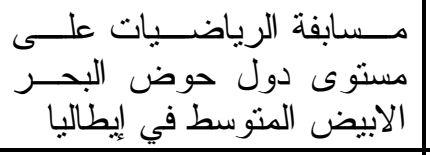 & $\begin{array}{l}\text { the Mediterranean } \quad \text { youth } \\
\text { mathematical championship }\end{array}$ & 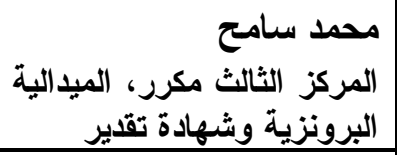 & rt \\
\hline ل للابتكار القاهرة الدولى الرابع & "Eco Brick" تطوير صناعة الطوب " & أحمد نبيل & r \\
\hline لـلابتكار القاهرة الدولى الر ابع & "Healing Without Feeling In D.M" & رئشرف حنفي اللقاني وروان & $r \varepsilon$ \\
\hline 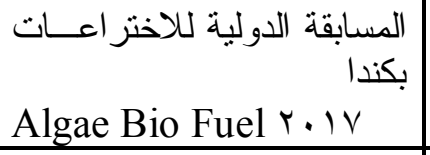 & $\begin{array}{l}\text { International invention innovation } \\
\text { competition }\end{array}$ & 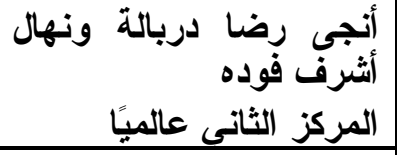 & ro \\
\hline $\begin{array}{l}\text { Hult prize بمركز النطوير بجامعة كفر الثيخ } \\
\text { التبنولوجى }\end{array}$ & nature for energy & 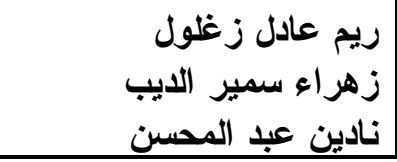 & r \\
\hline
\end{tabular}


مدرسة المتفوقين في العلوم و التكنولوجيا بالغربية

\begin{tabular}{|c|c|c|c|}
\hline اسم المسابقة & اسم المشروع & اسم الطالب & r \\
\hline creative day 2 & less blue more green & هبه حنفي محمود عبد الحي & 1 \\
\hline creative day 2 & less blue more green & رنيم عبد الله سعده & 2 \\
\hline creative day 2 & less blue more green & فاطمة حسنى محمد ابو شلق & 3 \\
\hline creative day 2 & less blue more green & منة الله محسن لقمة & 4 \\
\hline creative day 2 & Grey-Irrigation & ندي محمد بلير & 5 \\
\hline creative day 2 & Grey-Irrigation & روميساء شريف الصعيدي & 6 \\
\hline creative day 2 & Grey-Irrigation & ريم ايهاب التهامي & 7 \\
\hline creative day 2 & Grey-Irrigation & هاجر محمد مصطفي وهوه & 8 \\
\hline ابن الهيثم & water hyacinth power & محمد احمد حجازي راضي & 9 \\
\hline كأس مصر لإببداع و الابتكار & Grey-Irrigation & هاجر محمد مصطفى وهوه & 10 \\
\hline robotronics & irrigate from air & منار السيد عبد الغتى عيد & 11 \\
\hline ابن الهيثخ & high quality air filter & منار السيد عبد الغتي عيد & 12 \\
\hline ابن الهيثم & high quality air filter & فاطمة خالد مصطفي المزين & 13 \\
\hline BASEF & SMART IRRIGATION SYSTEM & نوران مصطفى احمد بكر & 14 \\
\hline ابن الهيثم & SMART IRRIGATION SYSTEM & نوران مصطفى احمد بكر & 15 \\
\hline كأس مصر لإبِد اع و الابتكار & irrigation hackers & سهاد حسام الدين & 16 \\
\hline كأس مصر لإببداع و الابتكار & irrigation hackers & ايه احمد حراز & 17 \\
\hline creative day 2 & for better future & اسلام مجدى ابو الغمرى العريان & 18 \\
\hline كأس مصر للإببداع و الابتكار & Grey-Irrigation & هاجر محمد مصطفى وهوه & 19 \\
\hline كأس مصر لإببداع و الابتكار & Grey-Irrigation & ريم ايهاب التهامي & 20 \\
\hline robotronics & irrigate from air & منه الله ناجح سعدون & 21 \\
\hline robotronics & irrigate from air & هاجز احمد رسلان & 22 \\
\hline robotronics & irrigate from air & نورهان محمد طلايع & 23 \\
\hline isef & irrigate from air & منـه الله نـاجح سعدون & 24 \\
\hline isef & irrigate from air & هاجر احمد رسدلن & ro \\
\hline
\end{tabular}

مدرسة المتفوقين في العلوم و التكنولوجيا بالمنوفية

\begin{tabular}{|c|c|c|c|}
\hline اسم المسابقة & اسم المشروع & اسم الطالب & م \\
\hline ISEF & SALVUM CARS & حنين حسام الدالى & 1 \\
\hline ISEF & SALVUM CARS & سما محمود هدهود & 2 \\
\hline ISEF & طاقة الطبيعة الخضر اء & فاطمة السيد عبد الله & 3 \\
\hline ISEF & معالجة المياه الملوثة إنشعاعيا & بسملة باسم إبر اهيم & 4 \\
\hline ISEF & معالجة المياه الملوثة إثعاعيا & ايناس سعد عطية & 5 \\
\hline ISEF & سيارة التوربينات & عبد الله محمد النحراوى & 6 \\
\hline ISEF & سيارة التوربينات & عبد الله جمال شهاب الدين & 7 \\
\hline ISEF & أغلق جروحنا & أغاريد أحمد الحريرى & 8 \\
\hline
\end{tabular}


دوبديدا محمود الإترى

\begin{tabular}{|c|c|c|c|}
\hline اسم المسابقة & اسم المشروع & اسم الطالب & م \\
\hline ISEF & أغلق جروحنا & لورا نبيل مطر & 9 \\
\hline ISEF & نهاية استخدام الانسولين (TEI ) & دعاء أسامة العربى & 10 \\
\hline ISEF & محاولة لإضعاف فيروس الايدز & نور هشام عبد الباسط & 11 \\
\hline ISEF & محاولة لإضعاف فيروس الايدز & سهيلة محمود شعر اوى & 12 \\
\hline ISEF & حياة أفضل مع البطاطا & ليلى أحمد إبراهيم الشرقاوى & 13 \\
\hline ISEF & إعادة شحن منظم ضربات القلب & مرام محمود أبو سالم & 14 \\
\hline ISEF & تمثيل مصر في الولايات المتحدة & سمين حسام الدالى محمود هدهود & 15 \\
\hline تحدى الروبوت & تمثيل مصر في الصين & فاطمة السيد عبد الله بهاء الجروانى & 16 \\
\hline بلاست اوف & تمثيل مصر في ايرلندا & 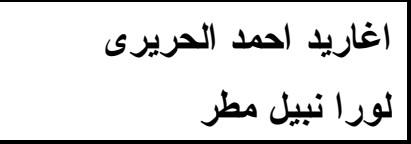 & 17 \\
\hline
\end{tabular}

ويتم القبول بهذا البرنامج بتقــدم كافــة

تلاميذ الصف الثالث الابتتـدائي مدــن تــصل أعمار هم إلى سن التاسعة لاجتياز جولتين مـن الاختبار ، الأولى وهي مرحلة المسح، و الثانيــة هي مرحلة الاختيار، وتقــرز نتــائج هـــاتين

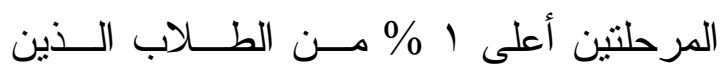
سينضمون للبرنامج، وخلال مرحلة (المسح) يتم اختبــار الطــلاب فــي اللغــــة الانجليزيـــة و الرياضيات، وبناءً على النتائج بــتم اســتبعاد مجمو عة من الطلاب، ومن يتبقى منهم ينتقل إلى مرحلة الاختيار حيث يــتم تطبيــق اختبــار ات أخرى فـــي الرياضـــيات و اللغــــة الانجليزيـــة بالإضافة إلى اختبار ات الذكاء، ومن يجتاز هذه المجمو عة من الاختبار ات يمنتل العينــة التــي Ministry of Education ستلتحق بالبرنامج. (in Singapore, 2012)

\section{المحور الثاني: بعض الاتجاهات العالمية المعاصرة في رعاية المتفوقين التياني:}

توجد عدة اتجاهات في رعاية المتفوقين و الاهنمام في دول العــالم المتقدمــة، تعــرض الباحثة منها:

Gifted الاتجـاه الأول: برنسامج تعليه الموهـوبين Education Program (GEP)

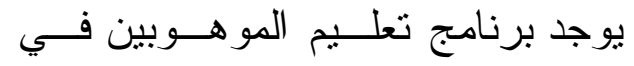
سنغافورة لتوفير قيادات ذات كفاءة عالية مــن الطلاب المتقوقين عقليًا لتطوير ذو اتهم و الإسهام في تقدم المجتمع، حيث يلتزم البرنامـ بتتميــة وتطوير قدر اتهم إلى أقصى ما تسمح به كمــا تتمنل رؤية البرنامج في الوصول للتميز فـي

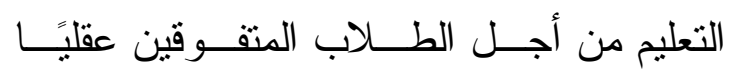
بالمرحلتين الابتدائية و الثانوية. 
الطالـــــب، و واختبـــــار ات القــــــات العقليــــة، و اختبار ات التحصيل، وقو ائم ملاحظة المعلــ،

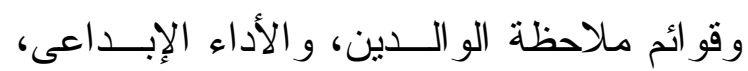
و الدرجات الددرسية.(Passow, 1993, 33) كما أن هناك العديد من النماذج و الأنظمة

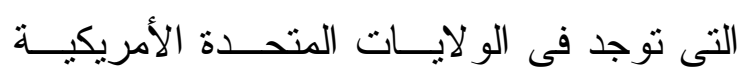

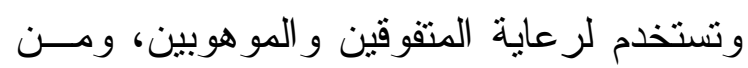
هذه النماذج ما يلى : - نموذج التعلم الذانى للمو هوبين و المتفوقين.

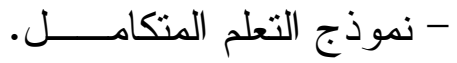
- نموذج بيردو للثباب القادرين المتقوقين.

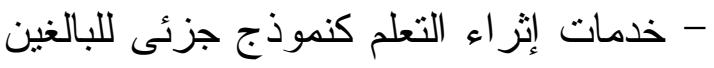

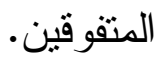

- تكوين المناهج المتغايرة للمتفوقين. - الإثر اء لاحتو اء خطة مدرسية على نطــاق القات و اسع لتتمية الإنتاج الإبداعى. - نموذج غرس المعرفة و القدرات الإبداعيــة المتعددة وتتميتها فى الطالب. - تطبيق مشروع القدرات المتعددة فى بر امج لمن المتفوقين.

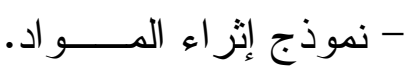
- نموذج تبنى تعلم مستقل ومؤثز من خـــلال

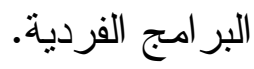

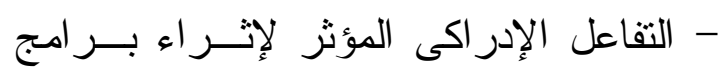

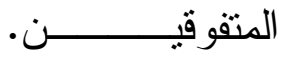

\section{الاتجاه الرابع: تطبيق نظـام اللاصفوف أو الإسـراع}

التعليمى Educational Acceleration ويقصد به تعديل نظام القبول و النقل من

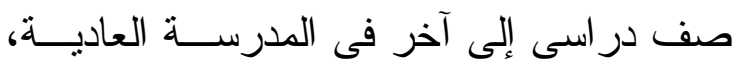

الاتجــاهالثـاني: الـبرامج التكامليـة أوالـدمج integrated programs تطبق البر امج التكاملية بالددارس الثانوية

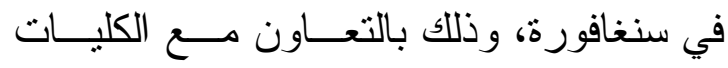
و المعاهد المتوسطة المنتسبة إليها، وتكون على النحو التالي: - الني - فصول مختلطـــة بهــا طــلاب البرنـــامج GEP وطلاب آخرون من خارجه. - التدريس لطلاب البرنامج في فصول خاصة فئه

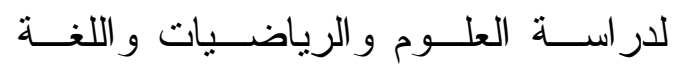
الإنجليزية، على أن يتم دمجهم مع زملائهم في مو اد الفنون وبعض الأنشطة :كالتربيـــة

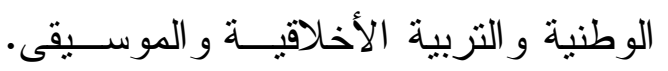
Ministry of Education in (Singapore, 2012)

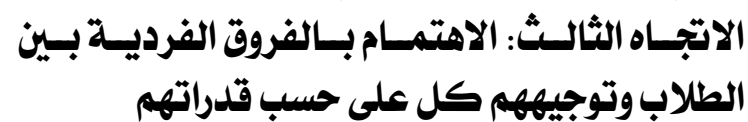
يتم الاهتمام بالفروق الفردية بين الطلاب

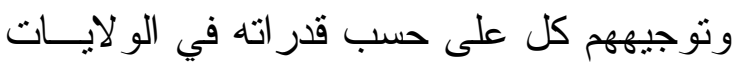

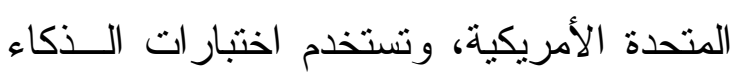

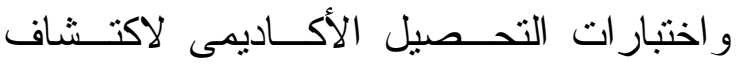

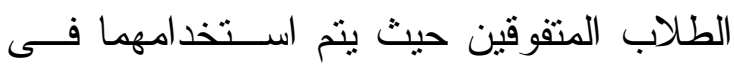

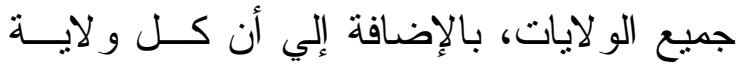

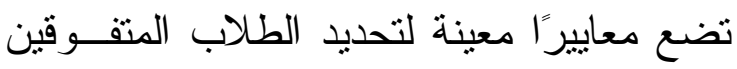

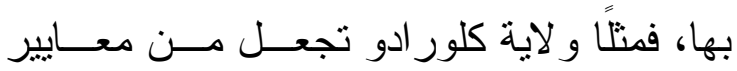

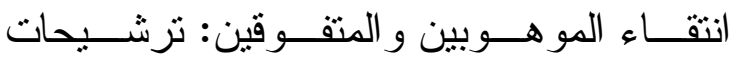

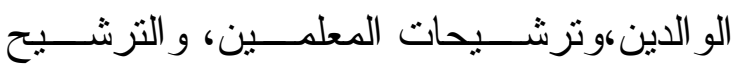

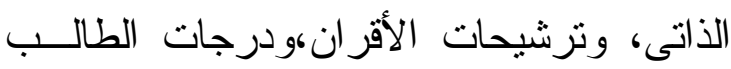

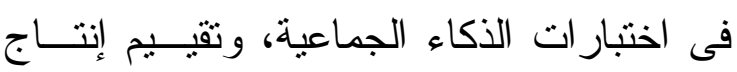


المو هوبين و الفائقين على مساعدة من هم أقــلـل

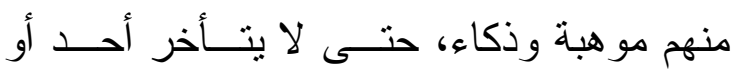
يتخلف عن بقية زملائه در اسياً، كما أنه قــائم على المناقثات الطلابية و الحوارات البناءة بين الطلبة بــين الطلبــة ذوى مـستويات الـــكاء المختلفة وتوجد بر امج متعددة لرعاية المتفوقين في اليابان منها :

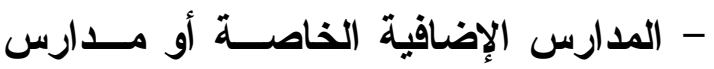
الجوكس: ويلتحق بهذه الددارس عدد كبير

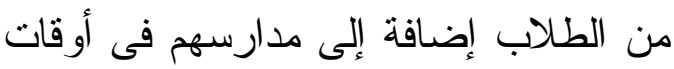
مختلفة سو اء فى المساء أم فى عطلة نهاية

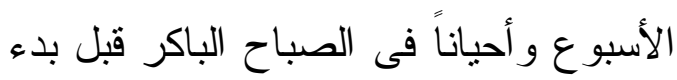

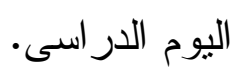

- مدارس تربية الذكاء: و الهدف مـن هـــه

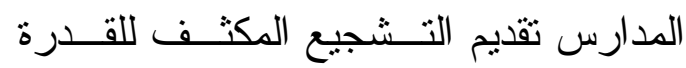
المعرفية وليس التحضبر لامتحانات القبول

$$
\text { المدرسية. }
$$

- معهر كومون للتربية: تأسس عـام 1901 فى مدينة أوساكا ويهتم بتدريس الرياضيات بصفة خاصة.

- المعهد اليابانى للتجديد و الابتكــــ : يحتـلـ هذا المعهذ مكان الصدارة فـى الأنـشطة

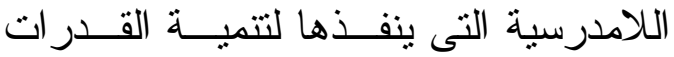

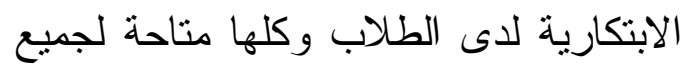

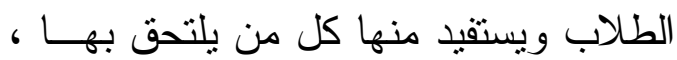

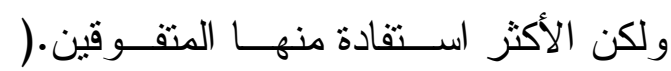
(Takeuchi, 1997,6
بحيث يساعد هذا النظام التلميذ الموهوب علـى إنهاء مر احله التعليمية فى عدد مــن الـسنو ات أقل من التلميذ العادى ، ويهدف هذا النظام إلى أن بسير كل تلميذ فى العملية التعليميــة وفـق فئق قدر اته ومو اهبه، فالتلميذ المو هوب ينتقل بمعدل

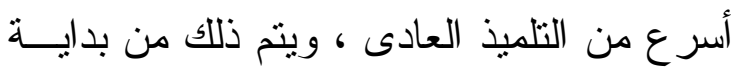

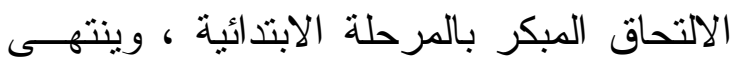
بالجامعة ، و الأمتلة على تطبيق هـــا الاتجــاه

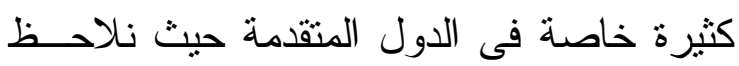

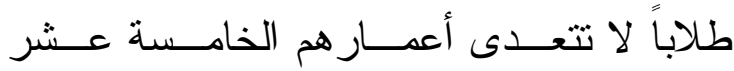

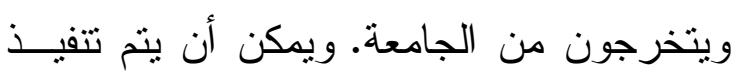
هذا الاتجاه من خلال الالتحاق المبكر بالمرحلة

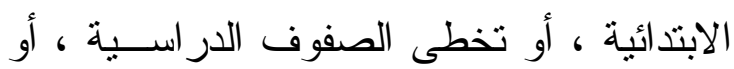
الإسر اع فى تعليم مادة معينة. Government) of South Australia, 2012, 7-8) يطبق نظام اللاصفوف في اليابان ويعني إنثاء مدارس بدون صفوف و السماح بتخطىى الصفوف الدراسية لتلبية احتباجات المتفــوقين الذين يتمتعون بقدرة على التعلم أسـر ع مــن

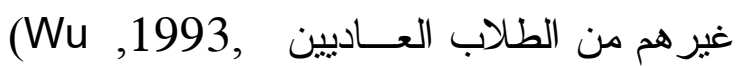

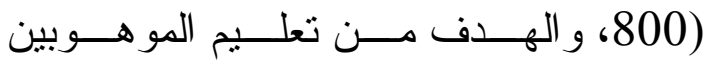
و المتفوقين فى اليابان هو مساعدتهم على تتمية مهار اتهم الخاصة سواء كان ذلك فى المجالات

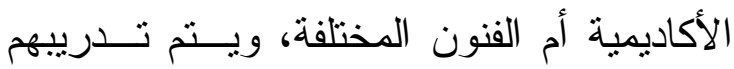
بو اسطة المعلمين و المدربين سو اء فى المنــزل أم فى المؤسسات الخاصة. و النظام التعليمى في اليابان يقــوم علــي

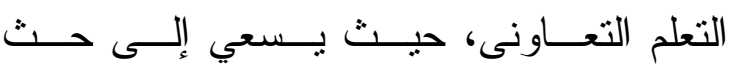


r. استخدام تقنيات الثقييم التكويني وحلقـات التغذية الر اجعة لتغيير الممارسة.

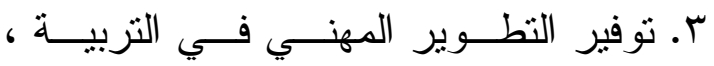
وخاصة لطلاب الدر اسات العليا.

ع. السماح للطلاب "بالقيام" بــالعلوم ، مثنـل فئل التعلم في المختبر ات وحل المشكلات. 0. توفير خبر ات تعليمية جماعية منظمة. 7. النأكد من أن المؤسسات نركز على نتائج التعلم. - الت من

V. تسلسل دورات رسم الخر ائط لخلق تجربة تعليمية متماسكة للطلاب. 1. تعزيز التعلم النشطو الفعال. 9. تطوير أهداف التعلم ومواعمة التقييمـات التهات

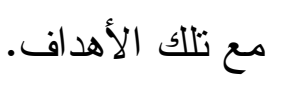
• ا. ا. تتجيع ما ور اء المعرفة.

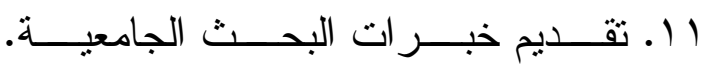
(Indiana State DOEd, 2013 p.

الإطار اليداني - اني

يجدر للباحثة قبل الوقوف علــي و اقــع مدارس المتفوقين من وجهة نظر عينة الدراسة

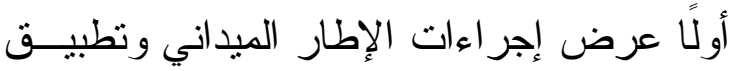

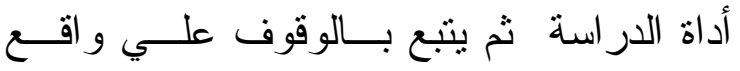
مدارس المتفوقين مسن خــلال ثنانيًا: تحليــل

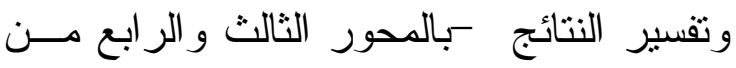

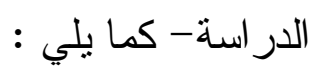
أولاً: إجرائات الإطار الميداني : الماني

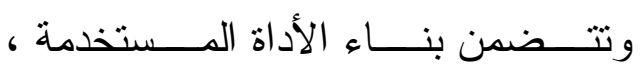

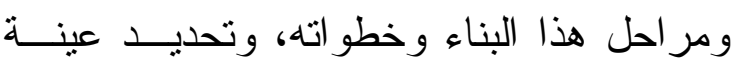

\section{الاتجاه الخامس: تنمية وتطوير رأس المال البشرى} وتعتمد كل من الصين وكوريا و اليابــان وسنغافورة علي تتمية وتطــــير رأس المــال البشرى حيث تؤكد هذه الدول علــى الابتكــار

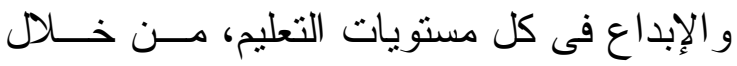
تحقيق تكامل فى الـسياسات التعليميــة بيـــنهم كمكون أساسى ومفتاح لاستر اتيجيات الإبـــاع

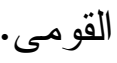
وبالنظر إلي مدارس المتفــوقين للعلــوم

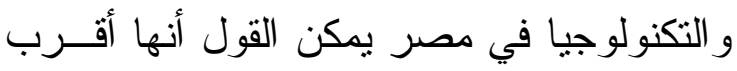
ما يكون إلي الاتجاه الخامس القائم علي نتميــــة

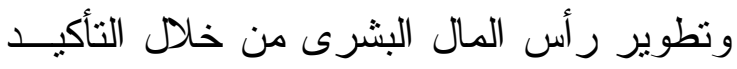

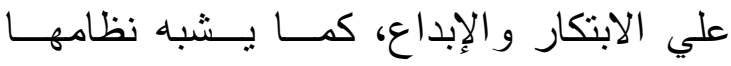

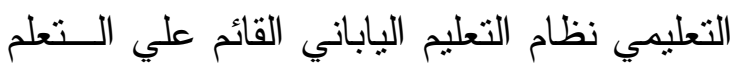

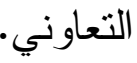

\section{الاتجاه السادس:التجميع أو تعليم STEM}

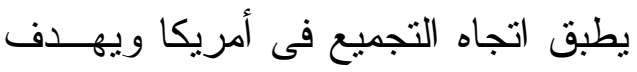

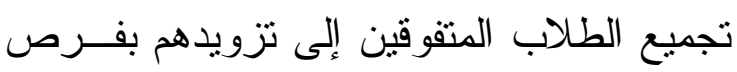
حل المشكلات وتحليل المو اقف الحياتية والتعلم من خبرات الحياة ذاتها وتحسين عملية الــتعلم لكل الطلاب الأمريكيين وتقدم المدارس بر امج تعليمية فعالة وأكثر تقدماً من المدارس العادية،

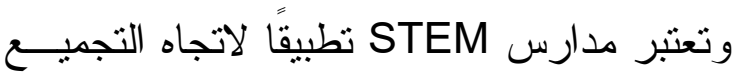
في الوقت الحالي، ويـــوفر مجلــس الأبحسـاث القومي في الولايات المتحدة ممارسات STEM التي يجب أن تتضمنها جميـع دورات STEM الأتى: ا ـ تدريس نظرية المعرفــة بـشكل و اضــح ومتسق. 
لتحقيق التقدم و العائد المأمول على صــيد كل من الفرد و المجتمع.

(r) صدق الأداة

اعتمدت الدر اسة على " صدق المحكمين"

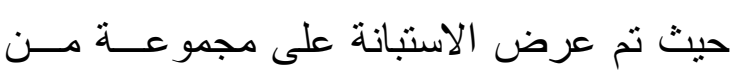

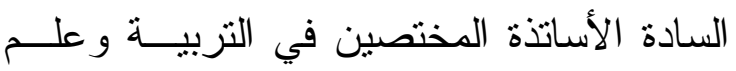
النفس وذللك بهدف اختبار صدق محتوى الأداة، وقد طُب من المحكمين إبداء وجهة نظرهم في مدى اتفاق بنودها مع الهدف الذى وضعت من ون

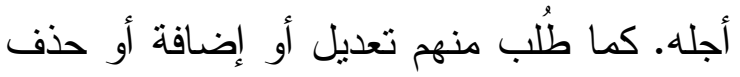
ما يلزم من وجهة نظرهم، وبناءً على وجهــة

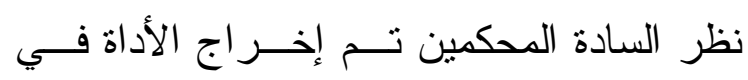

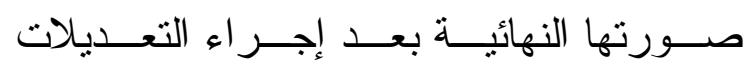
المقترحة.

وقد اكتقت الباحثة بصدق المحكمين لعدم وجود محك علمي سابق يقيس نفس متغيــر ات البحث الحالي كي تستند إليه الباحثــة كمقيــاس للتحقق من مدى صــدق اســتمارة الاســتبانة الحالية، بالإضـافة إلى اقتصـار البحث الحــالي

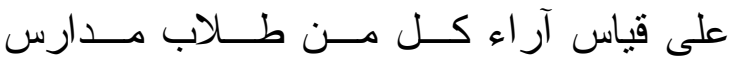
المتفوقين وكذا السادة المديرين و المعلمين بهـــا حول و اقعها من خلال محور و احد بكل استبانة يتضمن مجموعة من العبار ات الأمــر الــذي ولـي يحول دون تطبيق صدق الاتساق الداخلي الذي

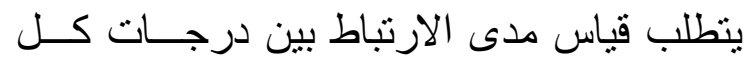

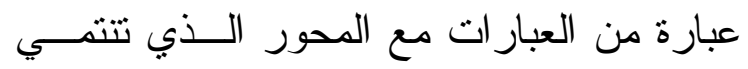

الدراسة، بالإضـافة إلى الأســلوب الإحــصائي الذى نم استخدامه في تحليل البيانات. (1) بناء أداة الاراسة : اســتخدمت الباحثـة

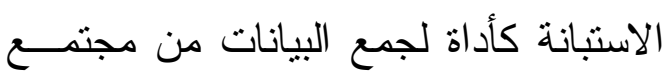

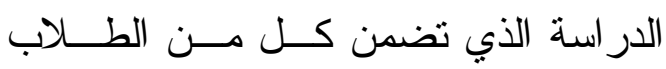
بمدارس المتفوقين من جانب، و المعلدـين بتلك المدارس من جانب آخر، ومن ثم فقد تم تصميم صورتين متباينتين من الاستبانة

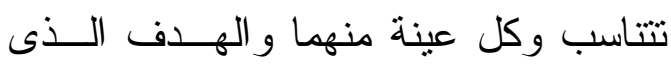
تسعى اليه الدراسة، وقد تم بناءها بالرجوع

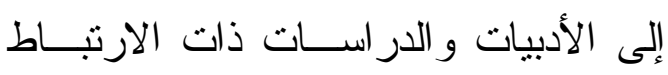
بموضوع الدر اسة، وقد اشتملت الاســنبانة الأولى (استبانة طلاب مدارس المتفــوقين) في صورتها النهائية علـى (10) عبــارة للتعرف على آراء طلاب مدارس المتفوقين حول و اقعها، في حين انتملت الاســنبانة الثانية (استبانة معلمي مدارس المتفــوقين) على (·r) عبارة في صــورنها النهائيـــة للتعــرف علــى آر اء الــسادة المــديرين و المعلمين بمدارس المتفوقين حول و اقعها،

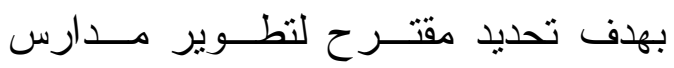
المتفوقين في ضــو بعـض الاتجاهــات

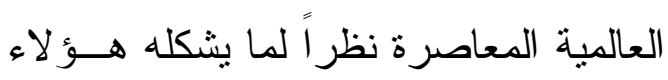
المتفوقين من ثروة حقيقية للمستقبل ينبخــي

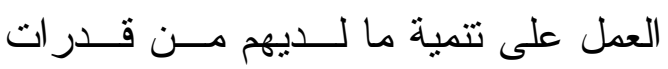

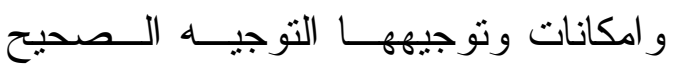


جدول (1) معامل الثبات (ألفا كرونباخ)

لكل من الاستبانة الأولى والثانية

\begin{tabular}{|c|c|c|}
\hline معامل & العبار ات & معامل الثبات \\
\hline .6971 & 10 & 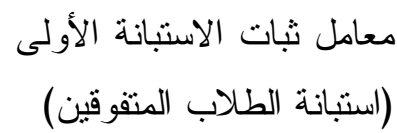 \\
\hline .691. & $r$. & 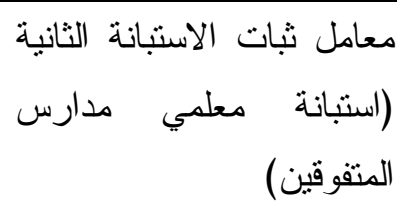 \\
\hline
\end{tabular}

يتضـح من جدول ( (1) ارتفــاع معامـلـل

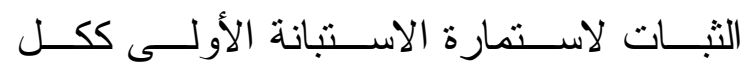

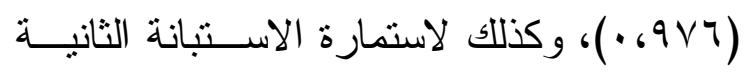

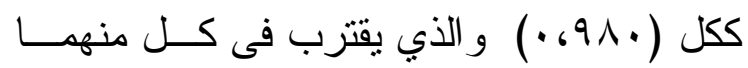

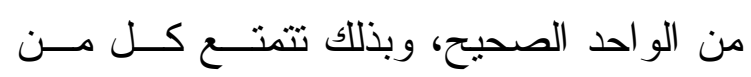

الاستبانتين بدرجة عالية من الثبات.

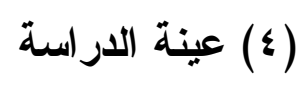

قامت الباحثــة بتطبيــق أداة الدراســـة

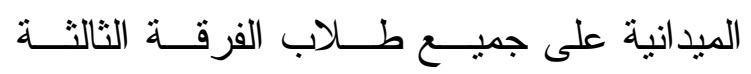

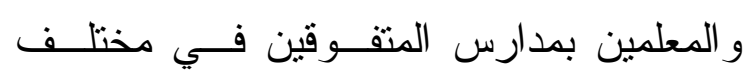
محافظات ومدن الجمهورية التي يوجد بها ذلك

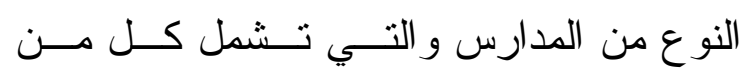

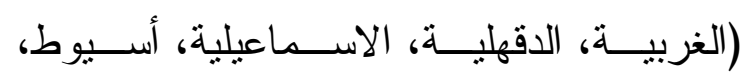

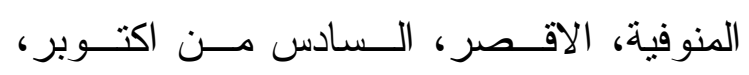
الاسكندرية، المعادي، كفــر الــشيخ، البحــر

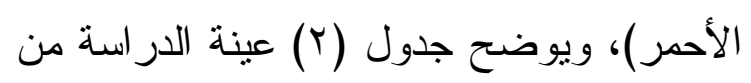

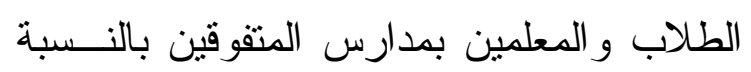

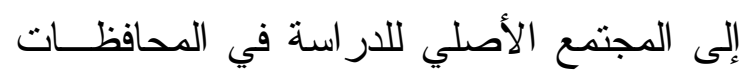
و المدن المختلفة.
إليه، ودرجة ارتباط كل محور مــع الدرجـة الكلية لاستمارة الاستبانة.

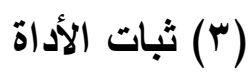

يقصد بالثبات دقة المقيــاس أو اتـساقه، الاهـان

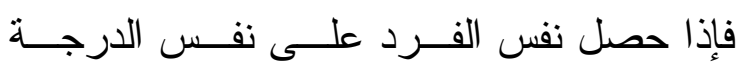

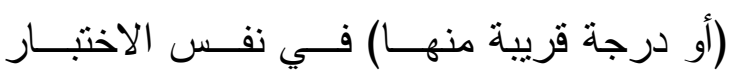

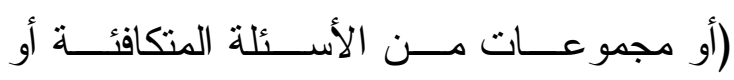

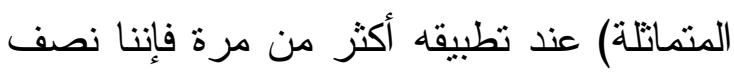

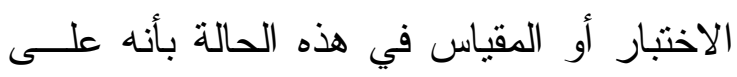
درجة عالية من الثبات.

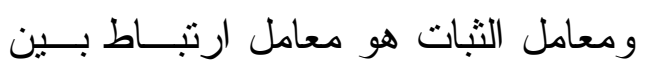
درجات الأفر اد في المقياس في مر ات الإجر اء

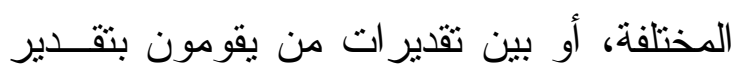

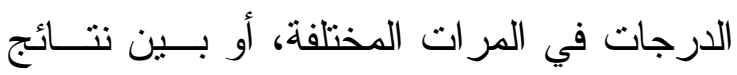

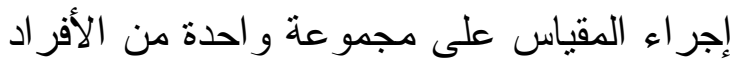

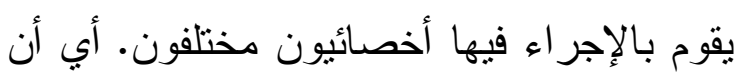
معامل الثبات هو معامل ارتباط بين المقيــاس

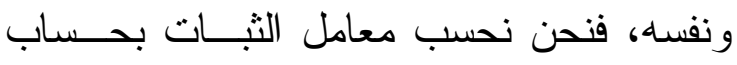

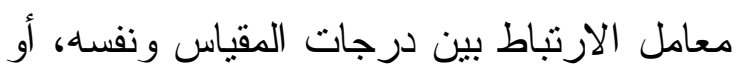
بين درجات المقياس وصورة أخــــى مكافئــة

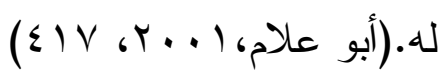
وقد قامــت الباحثــة بحسـساب الثبــات باستخدام طريقــة ألفـــا كرونبـــاخ لاســـــارة الاستبانة مجملة، ويوضح الجدول التالي معامل الثبات لكل من الاستبانتين الأولـى - اســنبانة الطلاب المتفوقين - و الثانية - استبانة معلمي الأني مدارس المتقوقين كما يلي : 
جدول (Y) عينة الدراسة من الطلاب و المعلمين بمدارس المتفوقين بالنسبة

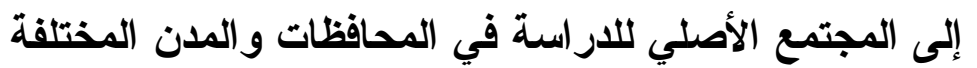

\begin{tabular}{|c|c|c|c|c|c|}
\hline \multicolumn{2}{|c|}{ عينة الدراسة } & \multirow{2}{*}{ المجتمع الأصلي للاراسة } & جتمي و أسينة & \multirow[b]{2}{*}{ اسم المدرسة } & \\
\hline$\%$ & العدد & & & & \\
\hline$\Lambda \varepsilon_{6} \mathrm{Y}$ & $r \mu$ & rA & المعلمين & & \\
\hline $9 T_{6} T^{2}$ & TrY & $1 \leqslant \mu$ & الطلاب & السادس من اكتوبر & \\
\hline$V Y_{6} V^{\prime}$ & $r r$ & $\varepsilon \varepsilon$ & المعلمين & & \\
\hline $9 \varepsilon_{6} \mathrm{~T}$ & $1 \ldots$ & 1.4 & الطلاب & المعادي & r \\
\hline 1.60 & Tr & §ा & المعلمين & & \\
\hline$A Y_{6} T^{\prime}$ & 19 & 97 & الطلاب & الإسكندريه & r \\
\hline $7 T_{61}$ & $T V$ & $\varepsilon r$ & المعلمين & & \\
\hline $0 \varepsilon$ & $r \varepsilon$ & $\pi$ & الطلاب & الدفهليه & $\varepsilon$ \\
\hline AT, & 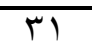 & rq & المعلمين & خ & \\
\hline 10 & $7 \pi$ & A. & الطلاب & حهر التيخح & 0 \\
\hline$\Lambda \Lambda_{6} 0$ & $\sum 7$ & Or & المعلمين & ةlich & \\
\hline$\Lambda \varepsilon_{6} V$ & $1 \ldots$ & 111 & الطلاب & الاسمحاعيليل & 1 \\
\hline 9960 & $r q$ & $r 1$ & المعلمين & & \\
\hline $70, \mathrm{Y}$ & 10 & $T r$ & الطلاب & اسيوط & v \\
\hline$\lambda \Gamma_{6} T^{\prime}$ & $r$. & ry & المعلمين & & \\
\hline 11,7 & $\mu$ & rA & الطلاب & البحر الاحمر & $\wedge$ \\
\hline$\Lambda \Lambda_{6} 0$ & $r \mu$ & KY & المعلمين & الأقتهت & \\
\hline $1 \ldots$ & 17 & 17 & الطلاب & الافصر & 9 \\
\hline $9 V$ & ru & re & المعلمين & اللغ بة & \\
\hline$\overline{-}$ & $\bar{Z}$ & $\overline{\bar{L}}$ & الطلاب & العزبيا & 1. \\
\hline $91 ، \varepsilon$ & $r r$ & ro & المعلمين & المن فية & \\
\hline$\overline{-}$ & $\overline{\bar{T}}$ & $\overline{\bar{Z}}$ & الطلاب & المنوفيه & 11 \\
\hline$A \Gamma_{6} \mathrm{~T}$ & $r \leqslant v$ & $\$ 10$ & المعلمين & II & \\
\hline$\lambda \varepsilon_{6} Y$ & ovo & דAr & الطلات & جلمـلي & \\
\hline
\end{tabular}

كما يتضح أن إجمــالي عـدـد الطــلاب

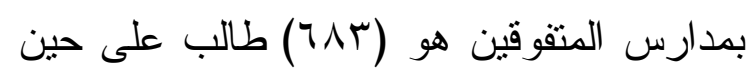

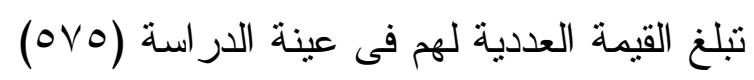

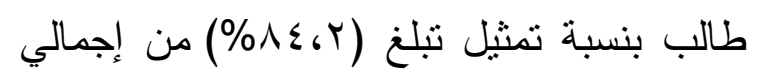
الطلاب في المجتمع الأصلي للار اسة. وكذلك فإن الجدول السابق يشير إلى أنى لأن

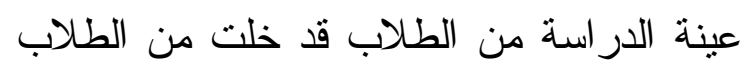

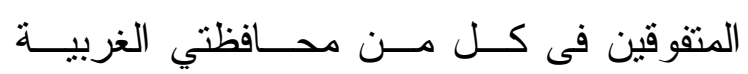

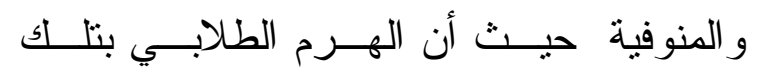
الدحافظات قد اقتصر على طلاب الصف الأول

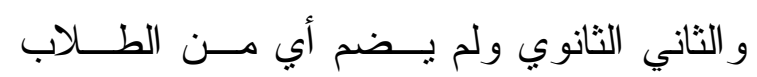

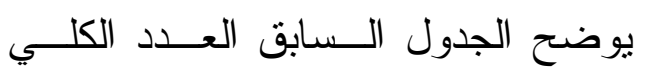

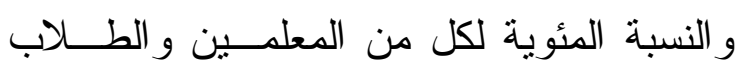

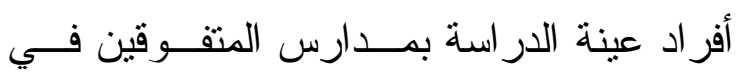

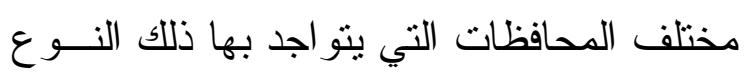

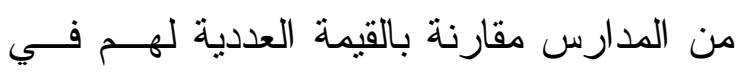

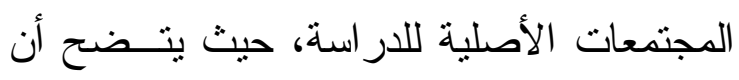

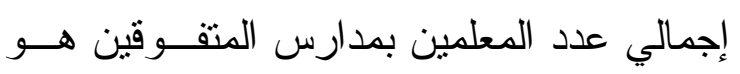

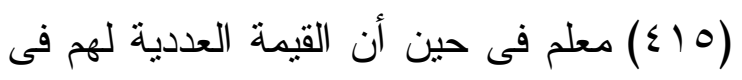

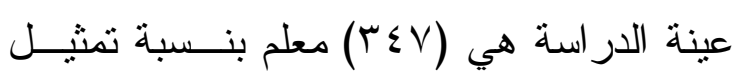

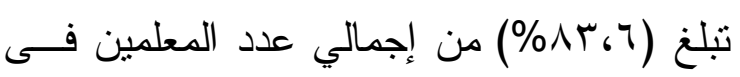

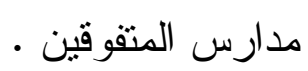


Statistical Package ) أب (Spss-V.25)

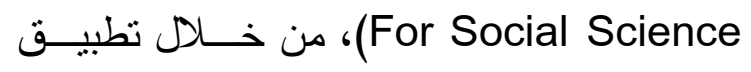
مجموعة من الأساليب الإحصائية التي نتتاسب من فئن

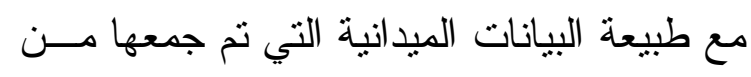

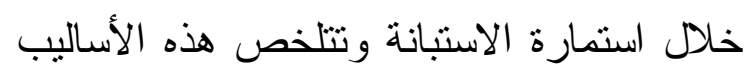

$$
\text { فيما يلي : خلي المارة }
$$

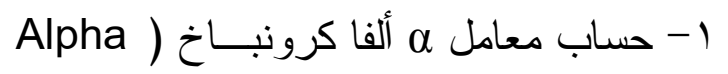

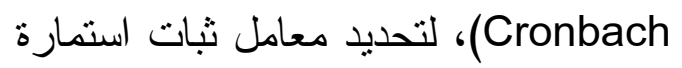

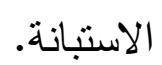

r- حساب التكر ار ات الخاصــة باســتجابات

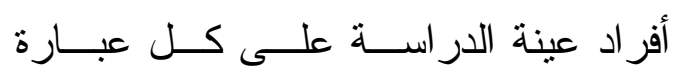
لاستمارة الاستبانة.

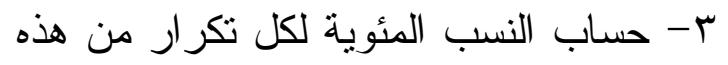

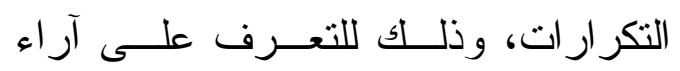

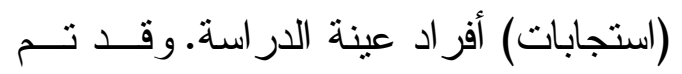

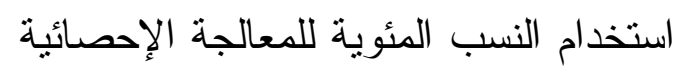

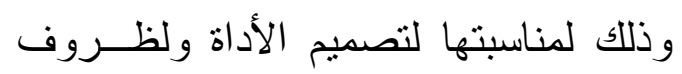
استجابات عينة الدر اسة.

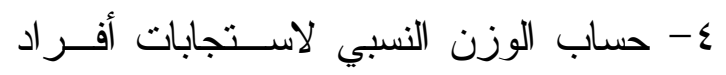

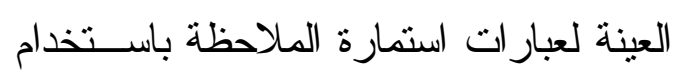
المعادلة الثالية :
المتفوقين بالصف الثالـــث الثــانوي (طــلاب الثانوية العامة - موضوع الدراسة - المنتمين لمدارس المتقوقين ). (0) تطبيق أداة الدراسة الميدانية ) لمدية

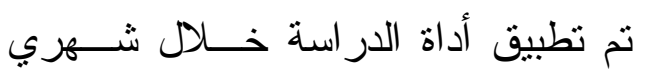

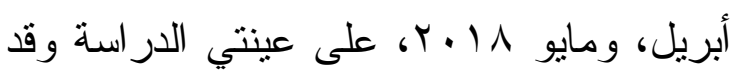

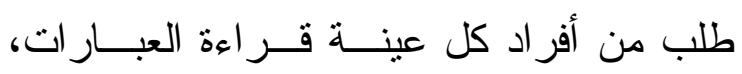

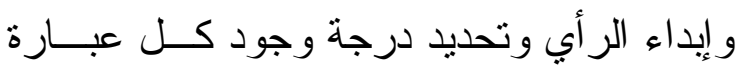
من العبارات، وذللك بوضع علامسـة (ل) فــي

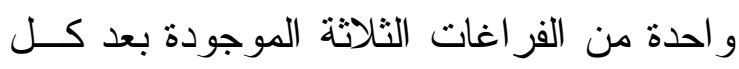

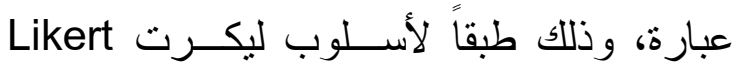

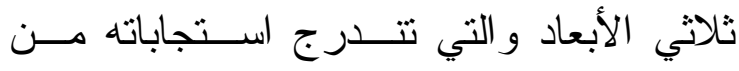

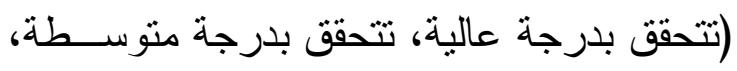

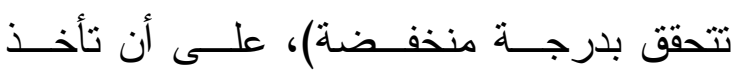
الاستجابة بدرجة عالية وزناً نسبياً مقداره ثلاثل

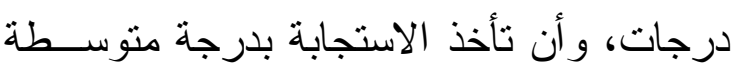
درجتين، بينما تأخذ الاستجابة بدرجة منخفضة الانة بدرهة درجة و احدة.

\section{(7) المعالجة الإحصائية}

تم معالجة بيانــات الدراســـة إحــصائياً

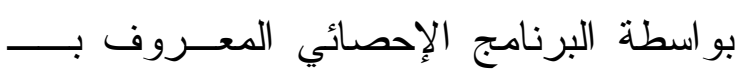

الوزن النسبي = × × تكرار مو افق + × × تكرار إلى حد ما + ( × تكرار غير موافق مجموع التكر ارات

جدول(ب) مستوى ومدى المو افقة لكل استجابة

\begin{tabular}{|c|c|}
\hline مدى المتوسطات & مستوى الاستجابة \\
\hline 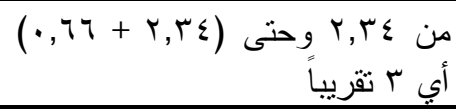 & بدرجة كبيرة \\
\hline 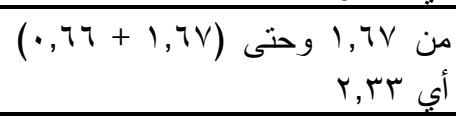 & بدرجة متوسطة \\
\hline من ا وحتى (1+ $17, \cdot)$ أي 17 ا & بدرجة ضعيفة \\
\hline
\end{tabular}

ولغايات التحليل الإحصائي للنتائج فقد تم

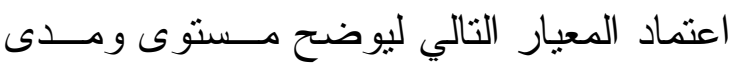

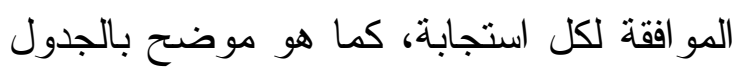

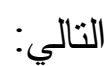


يوضح الجدول التالي درجة مو افقة عينة

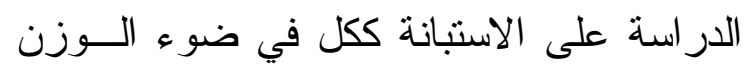

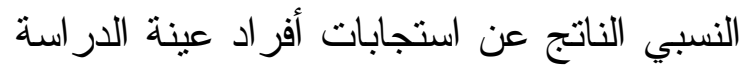

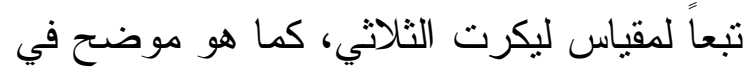

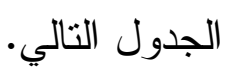

جدول( ) إجمالي استجابات أفراد العينة على استمارة الاستبانة ككل

\begin{tabular}{|c|c|}
\hline درجة الموافقة & المتوسط العام للاستبانة \\
\hline ro967r人 & $1 . V \pi$ \\
\hline
\end{tabular}

"دالة عند مستوى (.، ".

يلاحظ من الجدول السابق ما يلي : 1- أن تلك الجو انب التى تتعلق بتتمية قدرات الطلاب المتفوقين وتطوير امكاناتهم و التى لتى لتيه

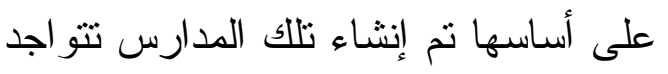

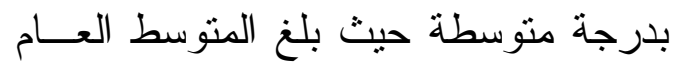

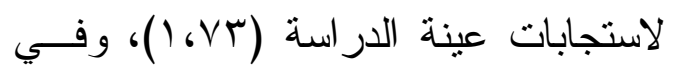
ذللك دلالة على ضرورة السعي نحو تقديم

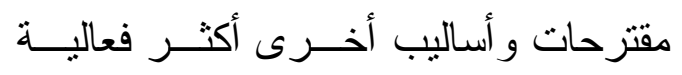
لتتمية مو اهبهر ونوجيهـا التوجيه الصحيح لتحقيق ما هو مأمول على صعيد الفرد.

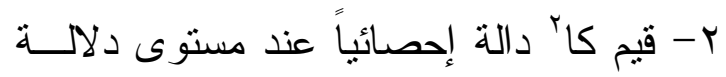

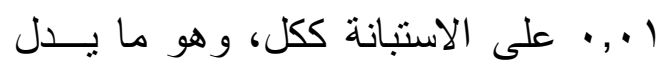
على وجود فروق ذات دلالـــة احـصائية لاستجابات طلاب مدارس المتفوقين مسن أفر اد عينة الدراسة على إجمالي الاستبانة

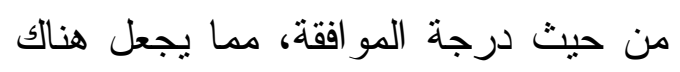

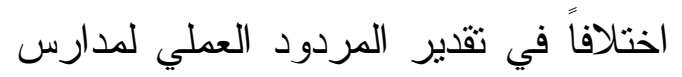

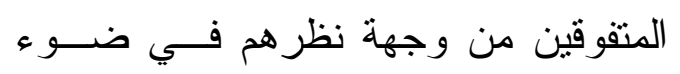

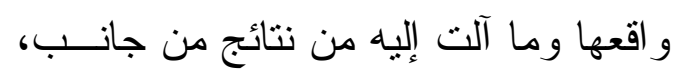

0- حساب (كــا؟) لمعرفـــة الفـروق بــين استجابات العينة على كل عبارة على حدة، من حيث درجة الموافقة، وللتحقق مما إذا عال على كان هنالك فروق ذات دلالة إحصائية بين

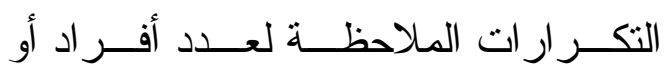

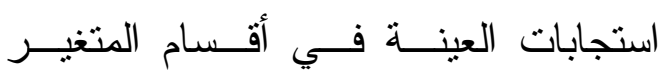
و التكرار ات الكتوقعة لعبــارات استــتمارة الاستبانة. ثثانياً : نتائج الجانب الميداني للاراسة: تتتاول الباحثة في هذا الجزء من الدراســـة

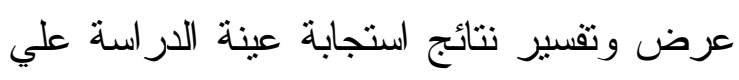

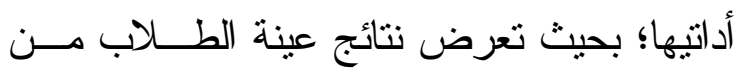

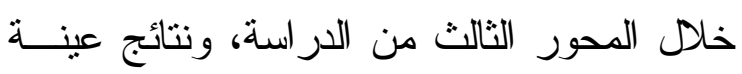

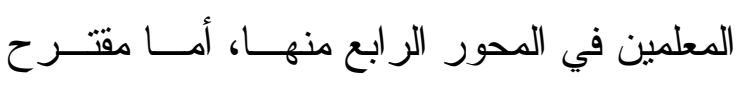

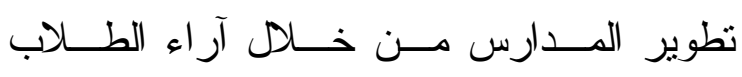

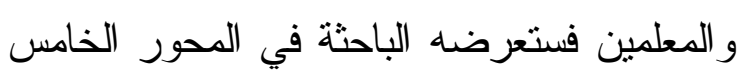

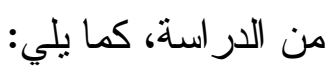
المحتور الثالث: واقع مدارس التتفوقين مسن وجهـة نظر الطلاب

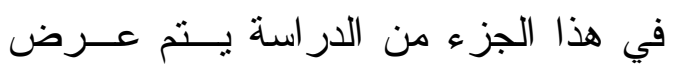

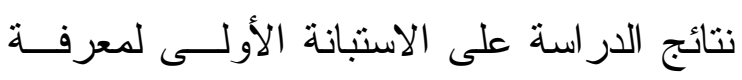
و اقع مدارس المتفوقين من وجهة نظر الطلاب:

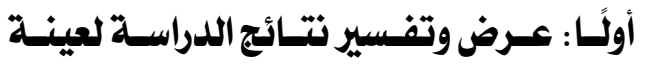

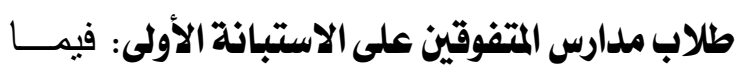

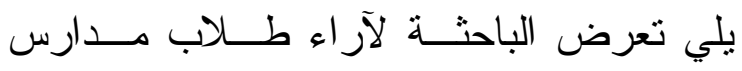
المتفوقين حول و اقع مدارسهم من خلال:

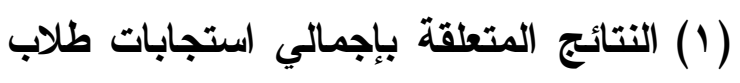
مدارس المتفوقين على الاستبانة ككل بلجئل 
يوضح الجدول التالي اســتجابات أفــر اد

عينة طلاب مدارس المتفوقين حول عبـار ات

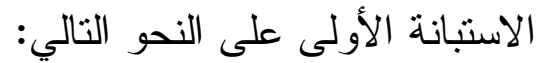

و وأمال وتطلعات الطلاب بها مــن جانـب

آخر

( إ) النتائج المتعلقة باستجابات أفــراد عينــة

طلاب مدارس المتفوقين حسول عبـارات

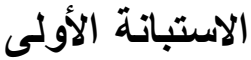

جدول(ه) استجابات أفراد عينة طلاب مدارس المتفوقين حول عبارات الاستبانة الأولى الإولى

\begin{tabular}{|c|c|c|c|c|c|c|c|c|c|}
\hline \multirow[b]{2}{*}{ الاحصائية ** * الالة } & \multirow[b]{2}{*}{ كاץ } & \multirow{2}{*}{ التزبيب } & \multirow[b]{2}{*}{ 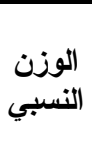 } & \multicolumn{3}{|c|}{ الاستجابة } & \multirow{2}{*}{\multicolumn{2}{|c|}{ 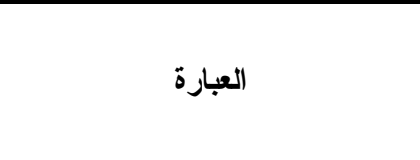 }} & \multirow[b]{2}{*}{ a } \\
\hline & & & & منتخفضة & مترجةق & تبرجة & & & \\
\hline \multirow[b]{2}{*}{ دالة } & \multirow[b]{2}{*}{ Yrq $6 \leq 7$} & \multirow[b]{2}{*}{1} & \multirow[b]{2}{*}{ Y.01 } & $r T$ & 510 & TrV & 5 & \multirow{2}{*}{ 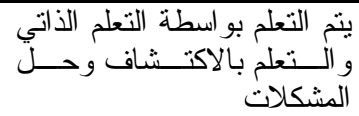 } & \multirow[t]{2}{*}{1} \\
\hline & & & & $0, \mathrm{~V}$ & rV، & 07,9 & $\%$ & & \\
\hline \multirow{2}{*}{ 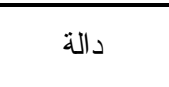 } & \multirow{2}{*}{ rq. r०q } & \multirow{2}{*}{ r } & \multirow{2}{*}{1.94} & $1 \wedge$. & roN & $1 \pi V$ & 5 & \multirow{2}{*}{ آر ائكم أكثاء الفرصة للتبع الدبير عن } & \multirow[t]{2}{*}{$T$} \\
\hline & & & & $r 1, r$ & $\varepsilon \varepsilon, 9$ & 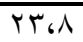 & $\%$ & & \\
\hline \multirow{2}{*}{ 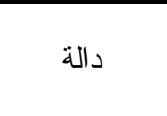 } & \multirow{2}{*}{$9 \varepsilon 6 r \vee 7$} & \multirow{2}{*}{1.} & \multirow{2}{*}{$1,7 \mathrm{~V}$} & rA. & $r \cdot \varepsilon$ & 91 & 5 & \multirow{2}{*}{ 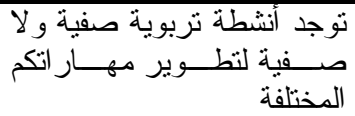 } & \multirow[t]{2}{*}{ r } \\
\hline & & & & $\sum \Lambda_{6} \vee V$ & $r 0,0$ & 10,1 & $\%$ & & \\
\hline \multirow{2}{*}{ 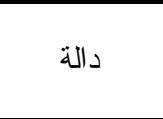 } & \multirow{2}{*}{ 1. V، $\varepsilon \wedge r$} & \multirow{2}{*}{11} & & $r \wedge \varepsilon$ & $r \cdot \Lambda$ & Ar & 5 & يوفر المناخ المدرسي فرصنَــا & $\varepsilon$ \\
\hline & & & 1.70 & $\sum 96 \varepsilon$ & M4.r & $1 \leq \varepsilon$ & $\%$ & 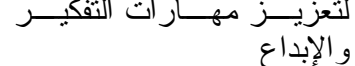 & \\
\hline & & & & $\sum 79$ & $\Lambda T$ & $r \varepsilon$ & ك & تعقـــــ معــسكر ات صــــفية & 0 \\
\hline دالة & $\pi \cdot 6 \mathrm{~V} \cdot$ & 10 & $1, \mathrm{TT}$ & 1).7 & $1 \leq 6$ & $\varepsilon_{6} r$ & $\%$ & تساعدكمة علي تتمية هو ايــاتكم & \\
\hline & & & & TTV & YrT & NT & 5 & توجد علاقـــة إيجابيـــة بــين & 7 \\
\hline دالة & $9 \Lambda_{6} 0 \cdot 1$ & 9 & 1.71 & $\leqslant 7$ ، & rq, r & $1 \leq 6$ & $\%$ & 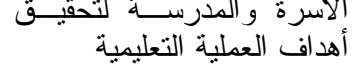 & \\
\hline لحي الة & $0 . r(1 \leq 7$ & $1 \leqslant$ & $1, r g$ & $\sum \varepsilon Y$ & $1 \cdots$ & $r \mu$ & 5 & توفر المدرسة شبكة إنترنـــت & $\bar{V}$ \\
\hline & & & & 87.9 & $1 V_{6} \varepsilon$ & $0 . \mathrm{V}$ & $\%$ & عالي السرعة & \\
\hline & $1<\pi, 1, \pi$ & $I^{\prime}$ & 1.7 & r97 & TIE & 70 & 5 & تشارك في اتخاذ القرار ات في & $\wedge$ \\
\hline & & & & 01,0 & rV.r & 11,4 & $\%$ & الأمور التي تخصك بالمدرسة & \\
\hline حالح & $\varepsilon \leqslant r \Delta V Y$ & سן & $1, r<$ & $\sum \curlyvee \wedge$ & $9 V$ & 0. & 5 & تخصص ميز انية للمتمبـزين & 9 \\
\hline & & & & $V \varepsilon ، \varepsilon$ & 17.9 & $\Lambda_{6} \mathrm{~V}$ & $\%$ & في الابتكار ات & \\
\hline & $y=011$ & $y$ & $1<<<<$ & $r \leqslant 0$ & THK & $9 \mathrm{~V}$ & ك & ير اعى الأخـــصائي النفــسي & 1. \\
\hline & & & & $\sum r_{6} 7$ & $\varepsilon \cdot, 0$ & 17.9 & $\%$ & مشكلاتكا ويعمل على حلها & \\
\hline & & & & $r \leqslant 1$ & Tro & 1.9 & 5 & يقدم الأخصائي الاجتمـــاعي & 11 \\
\hline دالة & $0 \leqslant 610$. & 7 & $16 \mathrm{~V}$ & $\leqslant 1,9$ & $r q, 1$ & 196 & $\%$ & 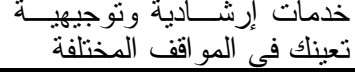 & \\
\hline & & & & 1.7 & TAY & $1 \wedge V$ & S & تتوفر المعامل الحديثَــة مثــلـل & Tr \\
\hline دالة & $\Lambda \cdot .9 V V$ & r & $\left.r_{6}\right) \leqslant$ & $1 \Lambda_{6} \varepsilon$ & $\leqslant 9_{6}$. & rro & $\%$ & مصامل العلوم و اللغات و مر اكز & \\
\hline & $0 \sigma^{2} r<r$ & 0 & $1+r$ & TIT & ro. & $11 r$ & 5 & أماكن الإقامة مجهزة بما يوفر & 14 \\
\hline & & & & $r_{V_{6} .}$ & $\sum \Gamma_{6} 0$ & 1960 & $\%$ & لكم الر احة & \\
\hline$\because 4$ & 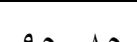 & 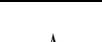 & 9 & TTY & 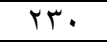 & NT & 5 & توجد مساحات وصالات كافية & $1 \varepsilon$ \\
\hline داله & 906.10 & $\wedge$ & 1674 & $\leqslant 0,7$ & $\varepsilon \cdot, \cdot$ & $1 \leq 6$ & $\%$ & لممارسة الهو ايات المختلفة & \\
\hline ل حالة & $r, r, Y$ & $\leqslant$ & 190 & $r \cdot r$ & $r T$. & $1 \leqslant r$ & 5 & يِعاملك مدير المدرسة كو الـــدُ & 10 \\
\hline داله & 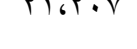 & $\varepsilon$ & $16 \wedge 4$ & ro,r & $\varepsilon \ldots$ & $r \varepsilon \sigma V$ & $\%$ & & \\
\hline & & & $1, \mathrm{VT}$ & & & لي للمد & & المتوسط الإجم & \\
\hline
\end{tabular}


التي تركز على المعلم إلى التربية التزبوية

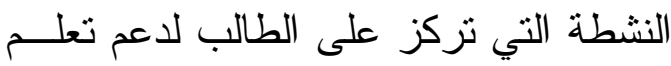
الطلاب وأن تتحول الممارسات التربوية في لتردي الفصل الدراسي نحو الأنشطة التي تعـزن

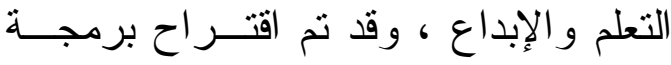

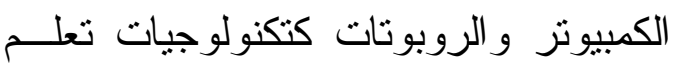
يمكن أن تساعد في تطوير الكفاءات ، مثل مهار ات حل المشكلات ومهار ات التفكيـر لئر

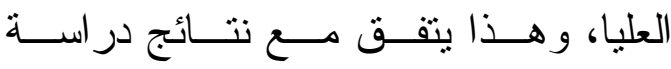
(Sumen \& Calisici, 2016 ) أنثارت إلي أن هناك سبع مهار ات حاســـة يحتاج فيها الطلاب إلى تطوير الخبــرات: 1. التفكير النقدي وحسل المــكلات ؛ ؟ ب. التعاون عبــر الــشبكات وقيــادة النفــوذ. ץ.القدرة على التكيف ؛ ع. المبادرة وريادة

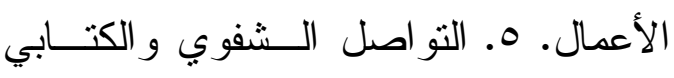
الفعال ؛ 1. الوصـــول إلــى المعلومـــات وتحليلها ؛ و V. الفضول و الخيــال. هــــه

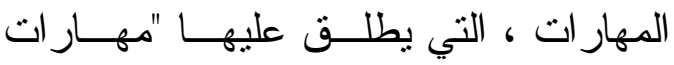
القرن الحادي و العشرين"،كما بينت نتــائج

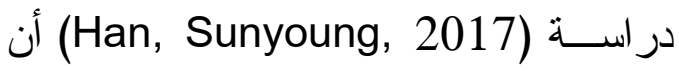
طلاب مدارس المتفوقين يتـسمو ا بكـــونهم

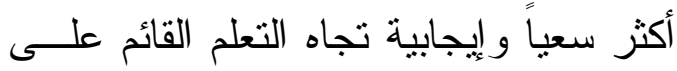

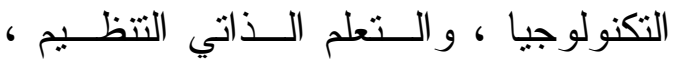

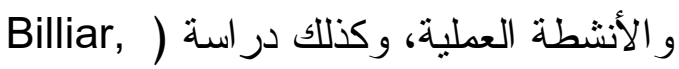
Asghar, ) (Kristen, 2014 (Anila, et al, 2012
من خلال استعر اض الجدول السابق يتضح ما يلي :

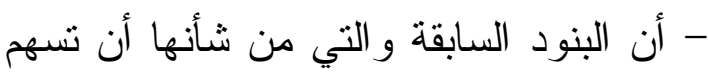

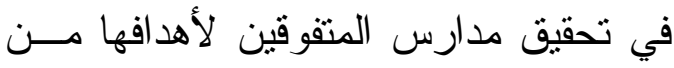

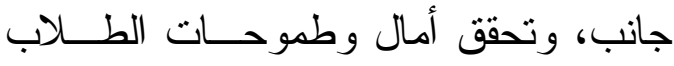

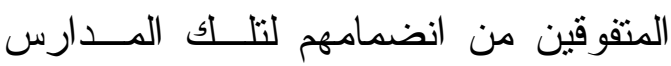
تنو اجد بدرجة متوسطة إلى ضعيفة باستثناء

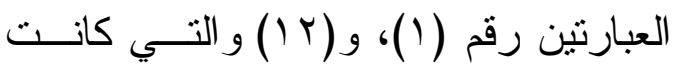
درجة التحقق فيهما كبيرة، حيث تز اوحـت الأوزان النـسبية لبــاقي العبــارات بــين

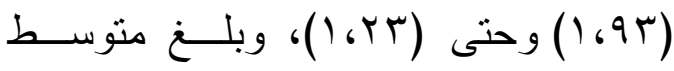
استجابة أفراد العينة على استمارة الاستبانة ككل (1،VT) - أكثز عو امل النجاح تحققــاً فــي مــدارس ل المتقوقين من وجهة نظر عينــة الدراســـة حسب ترتيب الوزن النسبي و الواقعة فـي في الإرباعي الأعلى مــن عبــار ات اســتمارة

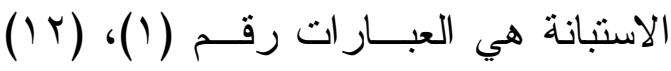
على التزتيب، حيث جاءت العبارة رقم (1) و التي تتص على (يتم التعلم بواسطة التعلم

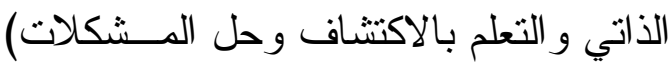

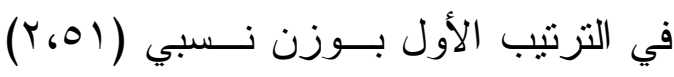

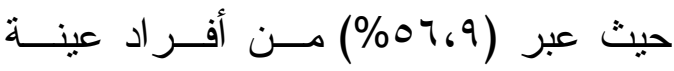

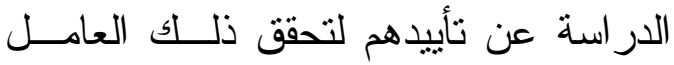
بدرجة كبيرة وقد أنتارت إلي ذلك در ساسة

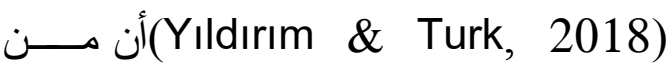

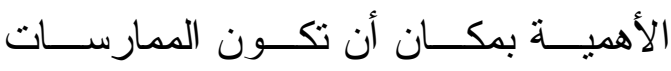
التربوية في STEM فعالة ، وأن يتم تغيير مناهج التدريس من طرق التدريس التقليدية 
(2015أن الإستر اتيجية الوطنية الأسترالية

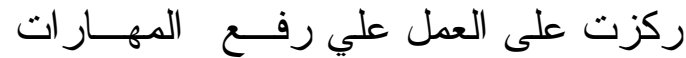
الأساسية في مجالات التعلم STEM مسن

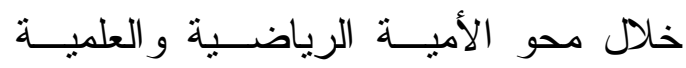

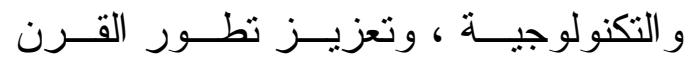
الحادي و العشرين ؛ مهار ات حل المشكلات و التحليل النقدي و التفكير الإبداعي، وأهمية التركيز على STEM منذ السنوات الأولى

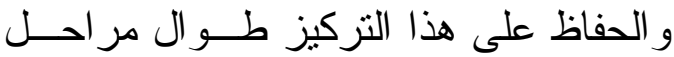

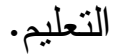

- ويلي ذلك في التزتيب العبارة رقــم (Y) و التي تتص على (تتوفر المعامل الحديثــة منل معامل العلوم و اللغات ومر اكز مصادر

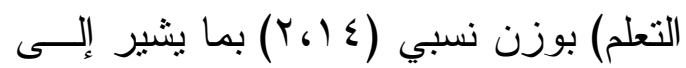

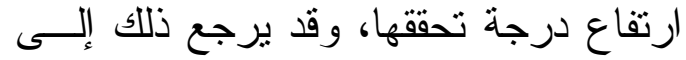

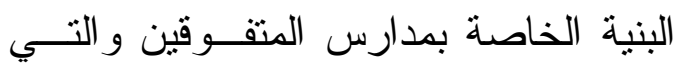
تستوجب ضرورة تزويدها بأحدث المعامل

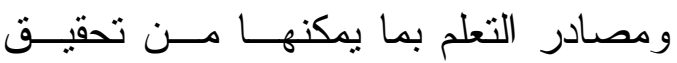

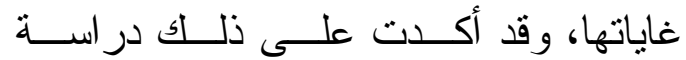
(Banerjee, Pallavi Amitava, 2017) و التي أوضحت إلى أنه من خلال ما ينو افر بمدارس المتفوقين من معامل وتجهيـزات

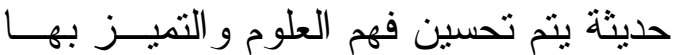
على المدى القصير وتتجيع مشاركة العلوم

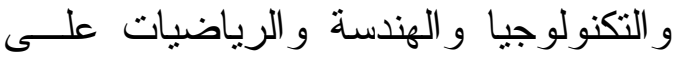
Ezeudu \& المدى الطويل، أما در اسة بمجموعة من الحلول (Ofoegbu, 2013) لمواجهة المشكلات التي تعتــرض تعلــيم

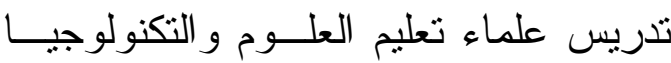
و الهندسة و الرياضيات بمدارس (STEM)

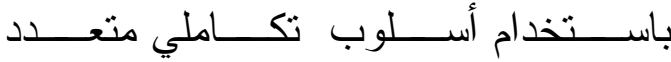
التخصصات يشجع الطلاب على التعـرف على العالم الطبيعي من خلال الاستكثافات

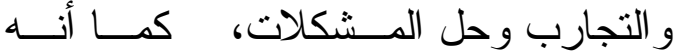
يساعدهم علي الاهتمام بمو اصلة الدراســة

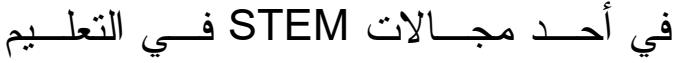

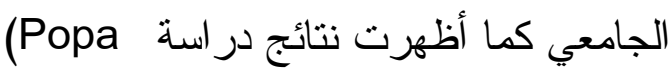
\& و المعلمين لهم دورًا Ciascai, 2017) في مساعدتهم وتوجيههم لهـــا الاختيــار ، Watermeyer, \& Montgomery, ) 2018)، أمـــا دراســة (Tyler , et al (2017فبينت أن مجلس البحوث الــوطني حدد ثمانية ممارســات للعلــوم و الهندســة ضرورية لجميع الطلاب للتعلم وهي: طرح الأسئلة للعلوم وتحديد المشكلات للاندسـة،

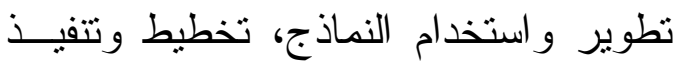
التحقيقات، تحليل وتقسير البيانات، استخدام الرياضــيات و التفكيــر الحــسابي، بنــــاء التفسيرات للعلوم وتصميم الحلول للهندسة، الانخر اط في الحجة من الأدلة، و الحصول

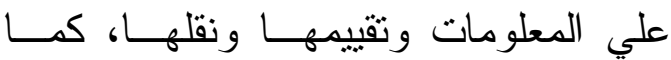
ركزت دراسة ) Guzey, S. Selcen et

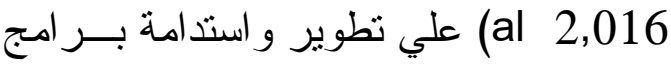

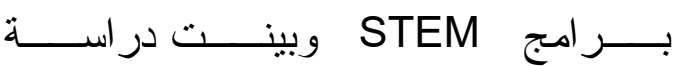
(NATIONAL STEM SCHOOL EDUCATION STRATEGY, 
و التي حازت ترتيباً متدنياً عن نظير اتهـا، وذللك حسب ترنيب الوزن النسبي و الو اقعة في الارباعي الأدنى مـن عبــارات هــــا

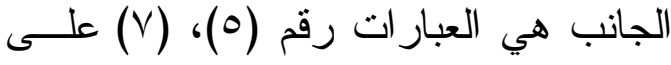

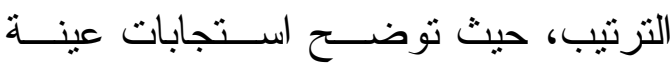

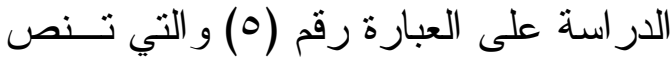
على (تعقد معسكرات صيفية نساعدكم علي تتمية هو اياتكم المختلفــة) إلـى تو اجــــــا

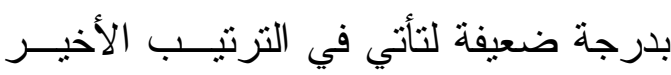

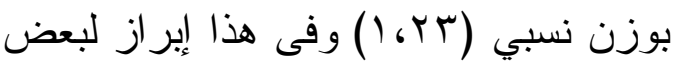
احتياجات الطلاب بمدارس المتفوقين و التنى أكدة عليها الدر اسات السابقة فــى نتائجهــــا

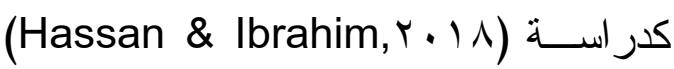
و التي أثنارت إلى أن أساليب التعلم الحديثة لم تعد تهتم بالوسيلة المتمحورة حول المعلم

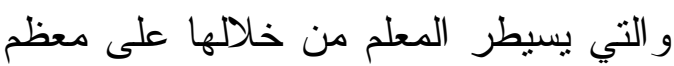

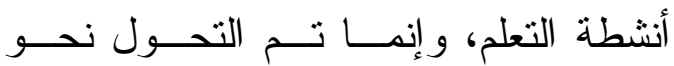
الأسلوب الذي يركز على الطلاب والــــي يوفر المزيد من الفرص للطلاب للابتكــار

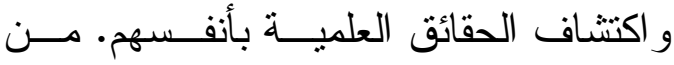

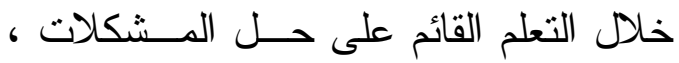
و التعلم التعاوني ، و التعلم الاستكثافي وأثر لفر ذللك على أداء الطلاب في التعلم.

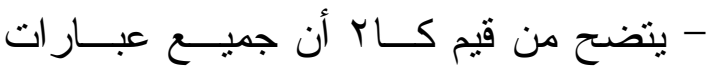

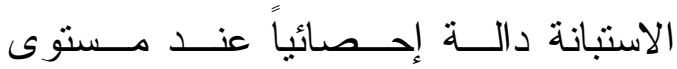

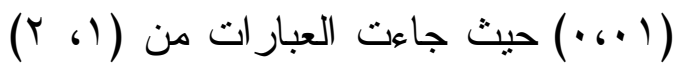

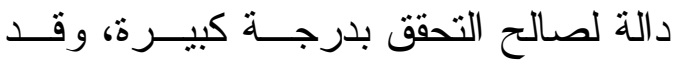

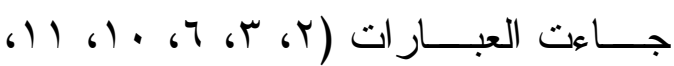

إدارة الأعمـــال فـي STM - بنيجيريــــ ومنها: توفير مختبــرات مجهـزة بــشكل مناسب في الــــارس، وتكــون المعـــات و المو اد ، وحتى المو اد المرتجلـــة كافيــة، وتوفير تكنولوجيــــا المختبـــرات و الفنـــين

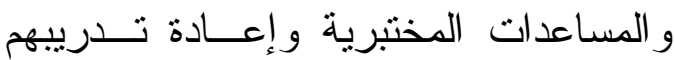
عليها

- ويأتي في النرتيب الثالث العبارة رقــم (r) حيث نوضح استجابات عينة الدر اسة علـى

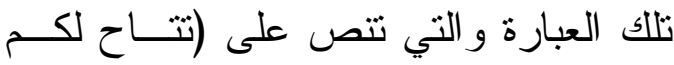
الفرصة للتعبير عن آر ائكـــم أثثــــاء اليــوم الدر اسي) إلى تحققها بدرجة متوسطة بوزن نسبي (با9، (1)وقد برجع ذلك إلى حداثــة التطبيق لنماذج مدارس المتفوقين في مصر و أثر ذللك على الفرص المتاحة و الموجهــة

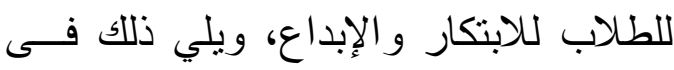

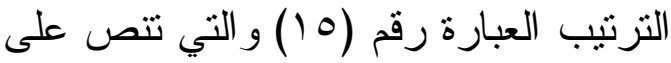

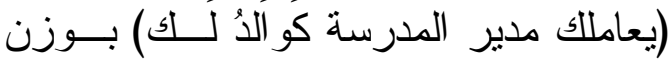

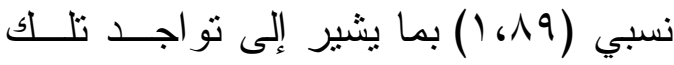
المؤشرات بدرجة متوسطة وهو الأمر الذي لئي تؤكده الأوزان النسبية لكل منهم، وقد يكون ذلك ناجماً عن نفس الأسباب الـسابقة مـن اختلاف النموذج الخاصة بمدرسة المتفوقين عن المدارس النقليديـــة العاديــة واحتيــــاج الإدارة لمدرسية بها إلى مزيد من الإعــداد و التأهيل المناسب. - أقل مؤشرات نجاح مدارس المتفوقين تحققاً وفقاً لو (قعها من وجهة نظر عبنة الدراســة 
التعليم الأساسي وتوفير فرص تمديد إضـافية

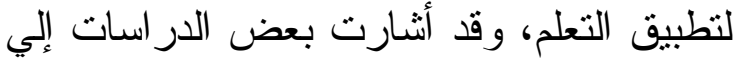

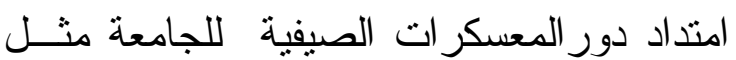
در اسة (Barroso et al, 2018) حيث نجحت معسكر ات STEM السكنية الصيفية لطلاب المرحلة الثنانوية في دمج نماذج للار اسة الجامعية لمساعدتهم على فهـم ثقافــة

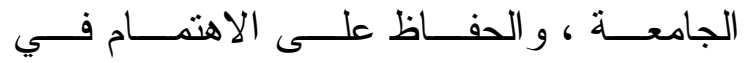

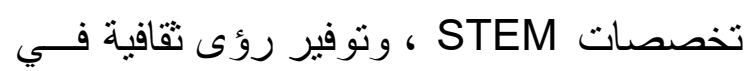
الكلية ، وتوجيهمح في خبر ات تعلم عملية. الأمر الذي يثير إلى وجود فروق ذات

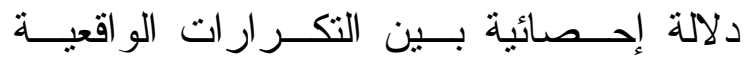

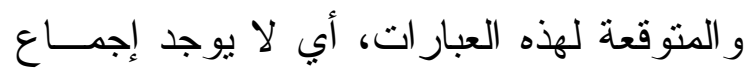

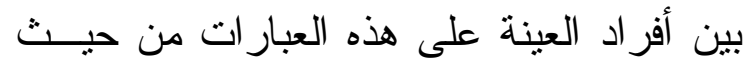
درجة التو اجد، حيث اختلفو ا حول مدى تحقـق لئق

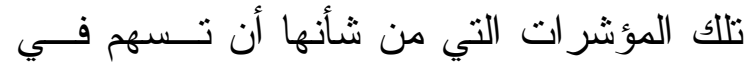

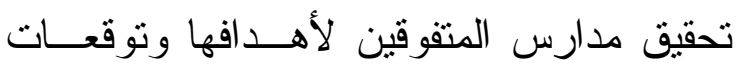

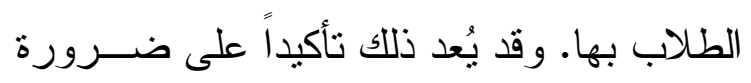

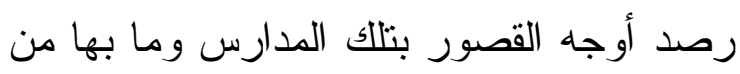

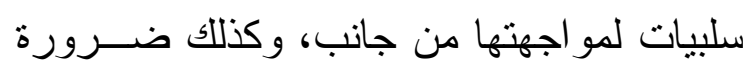
التعرف على احتياجـــات الطــلاب المتفـــوقين

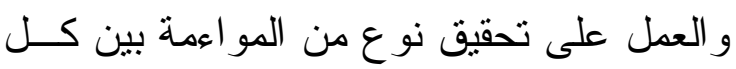

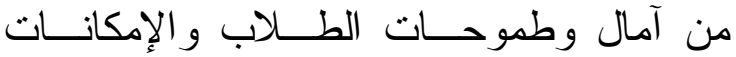

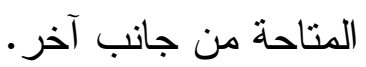
المحور الرابع: واقع مدارس التقــوقين مـن وجهـة نظـر

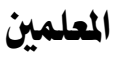
في هذا الجزء من الدراسة يتم عـرض

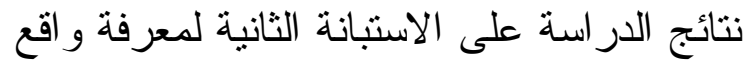
مدارس المتقوقين من وجهة نظر المعلمين:
با، ـ (، 10 ) و التي جاءت دالة لـصالح

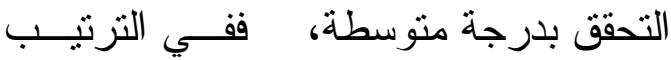

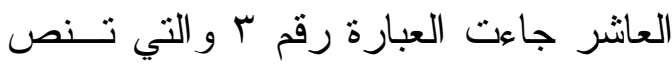
علي (توجد أنثطة تربوية صفية و لا صفية

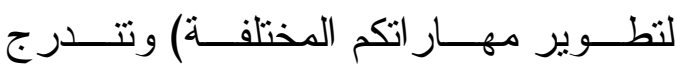
الدورات التدرييية للطلاب تحت الأنـشطة اللاصفية، تختلف هذه النتيجة مع دراســة

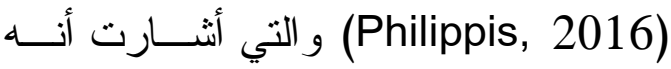

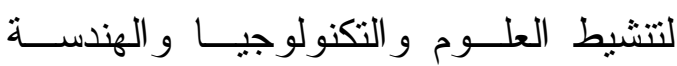

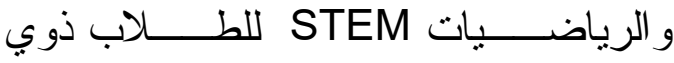
المهارات العالية، ينبغي على الحكومات أن تنظر في سياسة تهدف إلى تقديم المزيد من دورات العلوم للطلاب ذوي القدرات العالية في المدارس الثانوية.

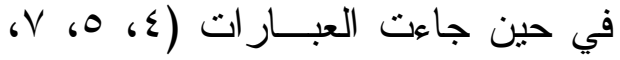
1، 9) دالة لصالح التحقق بدرجة ضعيفة،فمثنًا جاءت العبارة رقم ؛ و التي تتص علي (تــــفر إدارة المدرسة التعاون بيــكم فــي الأنـشطة الصفية وغير الصفية) لما قد يتحقق من خلاله فائدة للجميع في التريب الحادي عــشر ، وهــــه Rakich \& Tran, النتيجة تختلف مع در اسة

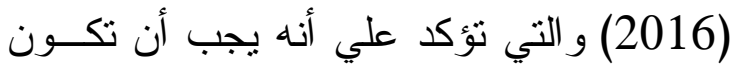
أهداف بـر امج STEM بالمدرســة الثانويــة مضاعفة لتتمية اهتمام الطلاب بمجالات العلوم و التكنولوجيا و الهندسة ، ثم سد الفجــوة بــين

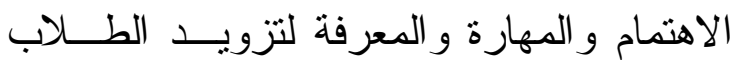

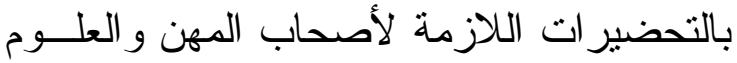
المهنية، وقد تم تصميم بر امج أو أنشطة لتعزيز 
الدراسة (10، (1). وفي ذللك دلالـــة علىى ضرورة بحث جو انب القــوة و الــضعف بمدارس المتفوقين و السعي الدؤوب نحسـو نابـ

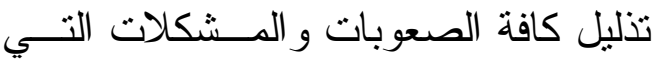
تو اجهها بما يمكنها من تحقيق أهدافها.

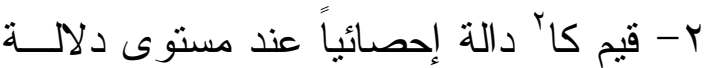

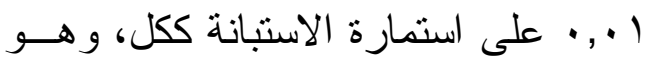
ما يدل على وجــود فــروق ذات دلالــــة احصائية لاستجابات المعلمين (أفراد عينة

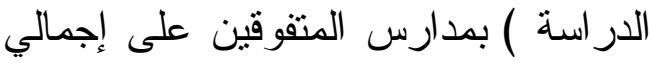

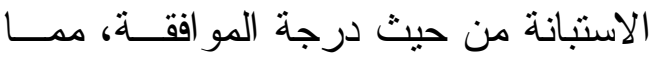
يجعل هناك اختلافاً في تقدير و اقع مدارس المتفوقين وما يتضمنه من جوانب ايجابية

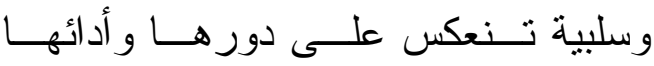
لوظيفتها من وجهة نظر هم.

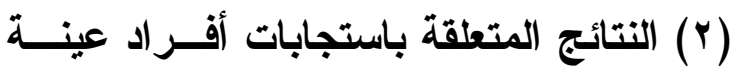
معلمي مـــارس المتفــوقين حــول عبــار ات الاستبانة الثانية

يوضـــح الجــدول التــالي اســتجابات

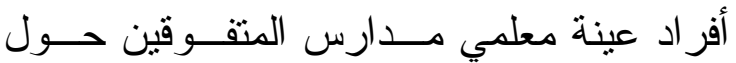
عبار ات الاستبانة الثانية على النحو التالي:
أولًا: عـرض وتفسير نتـائج الدراسـة لعينـة معلمي مدارس المتفوقين على الاستبانة الثانيـة: فيما يلــي ليدي تعرض الباحثة لآر اء معلمين مدارس المتفوقين حول و اقع مدارسهم من خلال: (1) النتائج المتعلقة بإجمالي استجابات معلمي مدارس المتفوقين على الاستبانة الثانية ككل يوضح الجدول التالي درجة مو افقة عينة الدراسة على الاستبانة ككل في ضوء الــوزن النسبي الناتج عن استجابات أفر اد عينة الدراسة الاستة

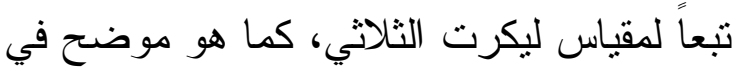

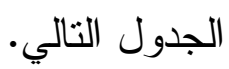
جدول(7) إجمالي استجابات عينــة المعلمـين

\begin{tabular}{|c|c|}
\hline درجة المو (فقة & المتوسط العام للاستباتة \\
\hline rVT,VIO & 1,10 \\
\hline
\end{tabular}
". يلاحظ من الجدول السابق ما يلي :

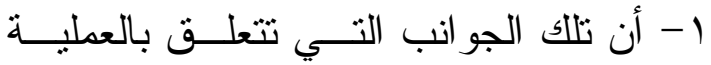

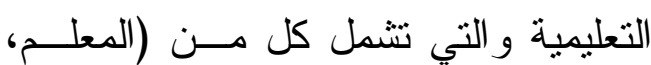
و الطالب، و الإدارة، و التجهيز ات و الأدو ات الدر اسية) نتو اجد بدرجة منوسطة حيــث

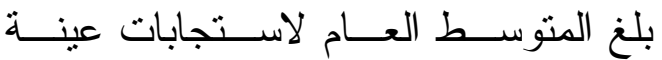


جدول(V) استجابات أفراد عينة معلمي مدارس المتفوقين حول عبارات الاستبانة الثانية

\begin{tabular}{|c|c|c|c|c|c|c|c|c|c|}
\hline \multirow[b]{2}{*}{ 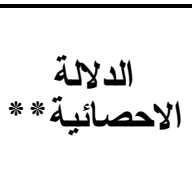 } & \multirow[b]{2}{*}{ كاr } & \multirow{2}{*}{ الترتيب } & \multirow[b]{2}{*}{ الن الوزب } & \multicolumn{3}{|c|}{ الاستجابة } & \multirow{2}{*}{\multicolumn{2}{|c|}{ العبارة }} & \multirow[b]{2}{*}{ b } \\
\hline & & & & منتفضضة & متورجة: & 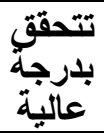 & & & \\
\hline \multirow{2}{*}{ 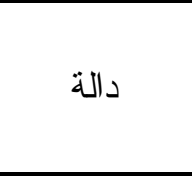 } & \multirow{2}{*}{90,049} & \multirow{2}{*}{ r) } & \multirow{2}{*}{1.09} & IVV & ITV & 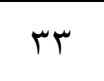 & 5 & \multirow{2}{*}{ 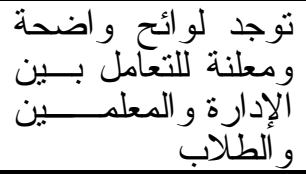 } & \multirow[t]{2}{*}{1} \\
\hline & & & & 016. & $r 9,0$ & 9.0 & $\%$ & & \\
\hline \multirow{2}{*}{ 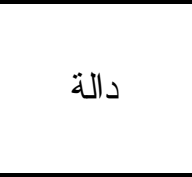 } & \multirow{2}{*}{ V V } & \multirow{2}{*}{ rA } & \multirow{2}{*}{ I.TV } & rAl & $\varepsilon$. & r & 5 & \multirow{2}{*}{ 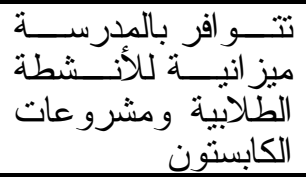 } & \multirow[t]{2}{*}{$r$} \\
\hline & & & & 116. & 11,0 & $V_{6} 0$ & $\%$ & & \\
\hline \multirow{2}{*}{ 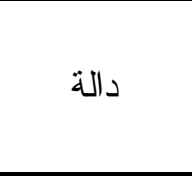 } & \multirow{2}{*}{$0.6 V \cdot r$} & \multirow{2}{*}{19} & \multirow{2}{*}{1.79} & IVT & 111 & $7 \varepsilon$ & 5) & \multirow{2}{*}{ 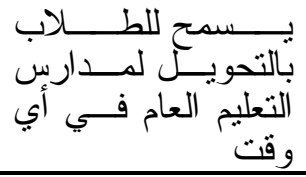 } & \multirow[t]{2}{*}{$r$} \\
\hline & & & & $\leqslant 9.7$ & r r.. & $1 \Lambda_{6} \varepsilon$ & $\%$ & & \\
\hline \multirow{2}{*}{ د لة } & \multirow{2}{*}{$1 \cdot 61 \cdot \varepsilon$} & \multirow{2}{*}{14} & \multirow{2}{*}{1614} & IrA & 119 & 9. & 5 & \multirow{2}{*}{ 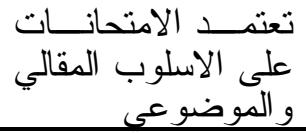 } & \multirow[t]{2}{*}{$\varepsilon$} \\
\hline & & & & $r q_{6} \wedge$ & $r \leq r$ & ro, & $\%$ & & \\
\hline & & & & TV & IVT & $1 \cdot 1$ & 5 & تسهر بر امتج التدريب & 0 \\
\hline داله & $2 \pi 6271$ & $11^{\circ}$ & 1.611 & 1964 & $\sum 9.7$ & 1.16 & $\%$ & 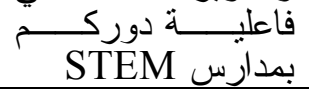 & \\
\hline ل & AO, rVY & r. & 1,7 & IVV & $1 \pi 1$ & rq & ك & تتو افر خدمة انترنت & 7 \\
\hline בות & $20,1 \mathrm{VI}$ & 1. & 161. & 016. & $r V_{6} \Lambda$ & 11,4 & $\%$ & عالي الس ع الس & \\
\hline & & & & $1 \cdot 1$ & 171 & 10 & ك & اليتاســـوم و منطلابـــــي & V \\
\hline & & & & $r q 61$ & $\sum 7_{6} \varepsilon$ & $r \leqslant 60$ & $\%$ & وُعمل المــشروعات & \\
\hline 散 & $10=0$ & $<$ & $r$ & דו & $1 \leqslant r$ & 171 & 5 & الــــرحلات العلميـــة & $\wedge$ \\
\hline - & . & 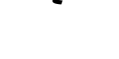 & 年 & $1 \cdot 6 \varepsilon$ & $\sum 1, r$ & $\varepsilon \Lambda_{6} \varepsilon$ & $\%$ & العملية التعليمية & \\
\hline لح الة & $1 / r \quad 0 r$ & 0 & سr & ro & 197 & 117 & ك5 & 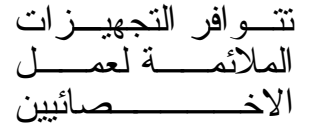 & 9 \\
\hline (1) & 等 & 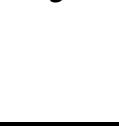 & 1011 & $1 \cdot 61$ & 07,0 & ז ع & $\%$ & 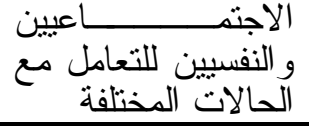 & \\
\hline & & & & IVT & 91 & NT & 5 & 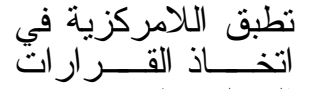 & 1. \\
\hline & & & & $\leqslant 9,9$ & Y Y, & $r$ r.9 & $\%$ & الاحتئجــات دانخـلـل & \\
\hline הII & $r$ & 1 & $5=0$ & 11 & $\Lambda V$ & $r \leq r$ & 5 & تــــــد العلاقِـــات & 11 \\
\hline (1) & 19600 & 1 & 16.0 & 0,4 & Y0, & 7962 & $\%$ & المعلمينين و الطّلبي بين & \\
\hline تل & & 7 & r & «0 & $19 \varepsilon$ & $1 \cdot 1$ & 5 & نشر الوعي بمدارس طلاب & IT \\
\hline (WI & 1. & 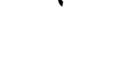 & 1610 & $1 r_{6}$ & 00,9 & 1,1 & $\%$ & للتعريف بها الإعداديــــة & \\
\hline
\end{tabular}




\begin{tabular}{|c|c|c|c|c|c|c|c|c|c|}
\hline \multirow[b]{2}{*}{ الاحصائية * * الالة } & \multirow[b]{2}{*}{ كاץ } & \multirow{2}{*}{ الترنبب النسبي } & \multirow[b]{2}{*}{ المبني } & \multicolumn{3}{|c|}{ الاستجابة } & \multirow{2}{*}{\multicolumn{2}{|c|}{ العبارة }} & \multirow[b]{2}{*}{ b } \\
\hline & & & & متخفضة & متوبنة & تبارجة: تالية & & & \\
\hline \multirow{2}{*}{ دالة } & \multirow{2}{*}{ rYA. $T \Lambda}$. & \multirow{2}{*}{ TV } & \multirow{2}{*}{1,40} & $r \leqslant 1$ & 91 & 10 & 5 & \multirow{2}{*}{ 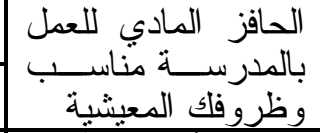 } & \multirow[t]{2}{*}{14} \\
\hline & & & & 7960 & YT.Y & $\varepsilon_{6} r$ & $\%$ & & \\
\hline \multirow{2}{*}{ د لة } & \multirow{2}{*}{$\varepsilon V$ V $9 T V$} & \multirow{2}{*}{11} & \multirow{2}{*}{1.97} & 94 & 187 & $\vee q$ & ك & \multirow{2}{*}{ 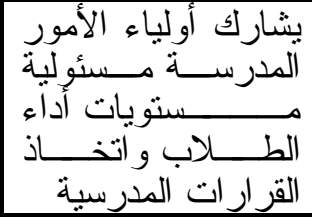 } & \multirow[t]{2}{*}{$1 \varepsilon$} \\
\hline & & & & $r r_{6} 0$ & $0.6 \mathrm{~V}$ & YY.A & $\%$ & & \\
\hline \multirow{2}{*}{ 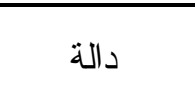 } & \multirow{2}{*}{$\left|V_{6} T^{M}\right| \leq$} & \multirow{2}{*}{17} & \multirow{2}{*}{ l, $1 \mathrm{Ar}$} & $1 \leqslant r$ & 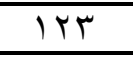 & $\Lambda 1$ & 5 & \multirow{2}{*}{ 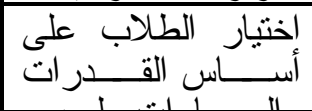 } & \multirow[t]{2}{*}{10} \\
\hline & & & & $\sum 1,4$ & robs & Tr.T & $\%$ & & \\
\hline \multirow{2}{*}{ 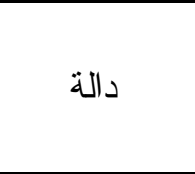 } & \multirow{2}{*}{ rVO,rTq } & \multirow{2}{*}{$r}$. & \multirow{2}{*}{$1,4 \pi$} & rAo & $\leqslant 0$ & IV & ك & \multirow{2}{*}{ 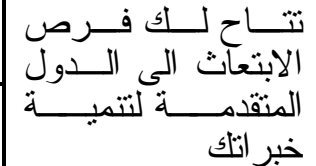 } & 17 \\
\hline & & & & $\left.\Delta r_{6}\right)$ & $1 r_{6}$ & $\varepsilon 69$ & $\%$ & & \\
\hline دالة & ror r. Y & $r q$ & $1, r \leqslant$ & rVq & or & 10 & ك & أينتكمال تلعليمهم فرص في & IV \\
\hline & & & & ᄉ. ، $\varepsilon$ & 10,5 & $\varepsilon_{6}$ & $\%$ & | غامعات نمطية & \\
\hline & & & & r.. & 11. & $r v$ & 5 & |توجد بروتوكــولات & 11 \\
\hline د لة & 110,471 & rt & 1.04 & $0 V_{6} 7$ & M. & $1 \cdot 6 V$ & $\%$ & 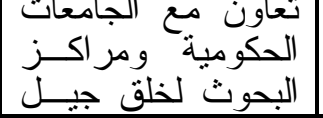 & \\
\hline & & & & TYO & $9 V$ & ro & 5 & تتبن & 19 \\
\hline 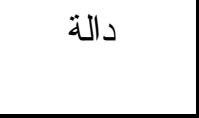 & $1 V_{6} \leqslant Y q$ & rT & $16 \leqslant r$ & $7 \varepsilon_{6} \Lambda$ & $r \wedge_{6}$. & $V_{6} r$ & $\%$ & 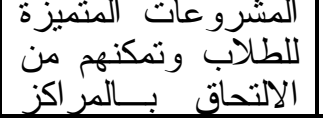 & \\
\hline & & & & $9 \varepsilon$ & 110 & Irk & ك) & 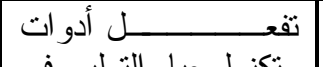 & $r$. \\
\hline دالة & A.TVO & 9 & T.1T & $\left.r V_{6}\right)$ & 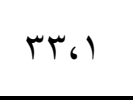 & $r 9,1$ & $\%$ & العدملية التعليمية دُخلَّ & \\
\hline دالة & 796197 & 10 & 1،八 & $11 \mathrm{r}$ & $\mid 11$ & $0 \leqslant$ & ك & |ختيار المعلمين وفقا & $Y_{1}$ \\
\hline & & & & rr, & OYGY & 10,7 & $\%$ & الكفاءة و التميز & \\
\hline دالة & $r_{r_{6}} \leqslant r_{r}$ & IV & $1, \lambda 1$ & $10 \mathrm{~V}$ & 99 & 91 & 5 & 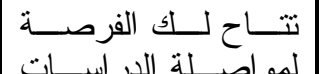 & MY \\
\hline & & & & $\sum 0, Y$ & $r \wedge, 0$ & YT.Y & $\%$ & العليا & \\
\hline & & & & rq & 19 & rrq & 5 & | يوجد دعم فني كـافي & $r T$ \\
\hline د لة & MT & r & $r_{6} 01$ & $\Lambda_{6} \varepsilon$ & Y0,7 & 77, & $\%$ & 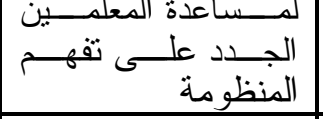 & \\
\hline & 1 wo,010 & $r \leqslant$ & 101 & r10 & $\Lambda V$ & $\leqslant 0$ & ك & |قامتة معار أفن سنوية & $r \varepsilon$ \\
\hline & & & & $\pi r_{6}$. & Yo, & $1 r_{6}$ & $\%$ & المشرو عات لتتفيذها & \\
\hline دالة & & & & rT. & v) & $\leq 7$ & ك & 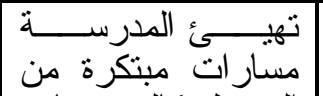 & ro \\
\hline & IVYGTYO & To & 1,68 & 77,4 & $r \cdot 60$ & 1T, & $\%$ & 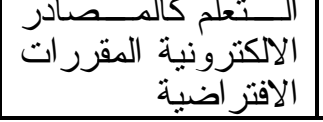 & \\
\hline
\end{tabular}




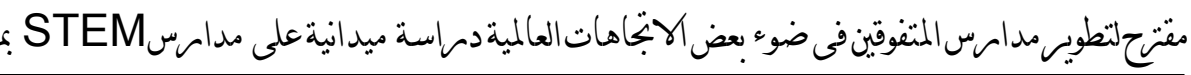

\begin{tabular}{|c|c|c|c|c|c|c|c|c|c|}
\hline \multirow{3}{*}{ الاحصائية * * الالة } & \multirow{3}{*}{ كاr } & \multirow{3}{*}{ الترتبب النسبي } & \multirow{3}{*}{ النسبي } & \multicolumn{3}{|c|}{ الاستجابة } & \multirow{3}{*}{\multicolumn{2}{|c|}{ العبارة }} & \multirow{3}{*}{ م } \\
\hline & & & & بتحقةق & بتحقة: & تلتحقة: & & & \\
\hline & & & & منظفضه & متوسطه & عالية & & & \\
\hline \multirow{2}{*}{ دالة } & \multirow{2}{*}{$1 \leqslant 0, r \wedge 0$} & \multirow{2}{*}{ r } & \multirow{2}{*}{1.04} & KYI & VY & $0 \leqslant$ & ك & 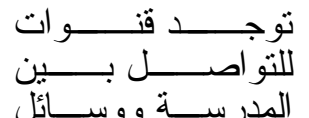 & r \\
\hline & & & & $7 \pi 6 \mathrm{~V}$ & $Y \cdot 6 V$ & 10,7 & $\%$ & 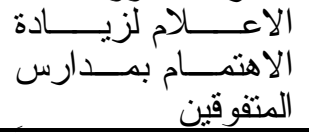 & \\
\hline \multirow{2}{*}{ دالة } & \multirow{2}{*}{ ror.r.V } & \multirow{2}{*}{$\wedge$} & \multirow{2}{*}{$\left.r_{6}\right) \leqslant$} & rVq & or & 10 & ك & \multirow{2}{*}{ 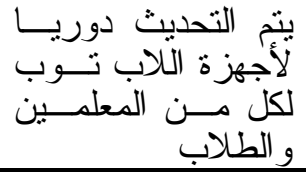 } & \multirow[t]{2}{*}{ TV } \\
\hline & & & & A. ، $\varepsilon$ & 10,4 & $\varepsilon_{6} r$ & $\%$ & & \\
\hline \multirow[b]{2}{*}{ دالة } & \multirow[b]{2}{*}{ 1 s.or. } & \multirow[b]{2}{*}{$1 \varepsilon$} & \multirow[b]{2}{*}{$1, \wedge \leqslant$} & $1 \leqslant 1$ & $1 \cdot v$ & 94 & 5 & \multirow{2}{*}{ 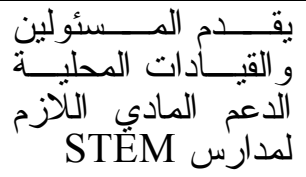 } & \multirow[t]{2}{*}{ rA } \\
\hline & & & & $\sum r_{6} V$ & $r \cdot ، \Lambda$ & $r 4,0$ & $\%$ & & \\
\hline \multirow[b]{2}{*}{ د دالة } & \multirow[b]{2}{*}{$1.1690 \leqslant$} & \multirow[b]{2}{*}{ v } & \multirow[b]{2}{*}{ r.17 } & $\sum 7$ & 191 & $1 . r$ & 5 & \multirow{2}{*}{ 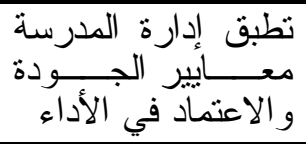 } & \multirow[t]{2}{*}{19} \\
\hline & & & & 146 & $0 V_{6} 1$ & rq.V & $\%$ & & \\
\hline \multirow[b]{2}{*}{ د دالة } & \multirow[b]{2}{*}{$197.1 V T$} & \multirow{3}{*}{ r } & \multirow[b]{2}{*}{ r.7T } & YI & 90 & rMI & ك & \multirow{2}{*}{ 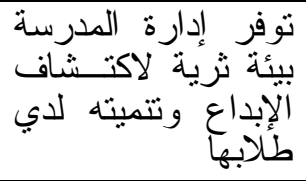 } & \multirow[t]{2}{*}{$r}$. \\
\hline & & & & 7,1 & YV $6 \varepsilon$ & 77.7 & $\%$ & & \\
\hline & & & 1,10 & & & & & سط الإجمــــــــــالى للـ & 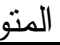 \\
\hline
\end{tabular}

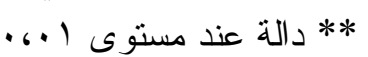

من خلال استعر اض الجدول السابق يتضح ما يلي :

- أكثر المؤشر ات الدالة على نجـــاح البيئــة

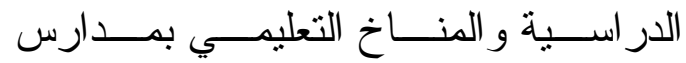
المتفوقين من وجهة نظر عينــة الدراســـة حسب نرتيب الوزن النسبي و الواقعة فــي الإرباعي الأعلى من عبــارات الاســتبانة الثانية (استبانة معلمي مدارس المتفــوقين)

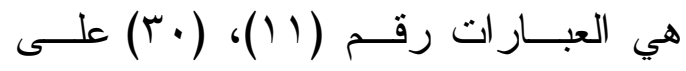
الترتيب، حيث جاءت العبـارة رقــم (1) و التي تتص على (تسود العلاقات الإنسانية الطيبة بين المعلمين و الطلاب) في التزتيب

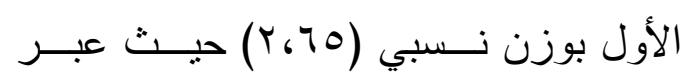

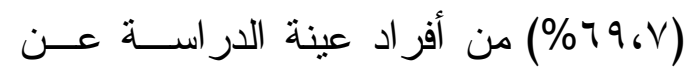

- أن تلك الجوانــب التــي تتعلــق بالعطليــة التعليمية بمدارس المتفوقين و التي تتمل كل

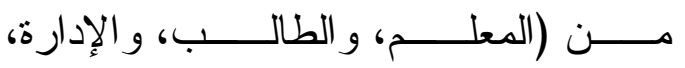
و التجهيـــز ات، و التنـــــاعلات و العلاقــــات الصفية) تتحقق بدرجة متوسطة إلى ضعيفة

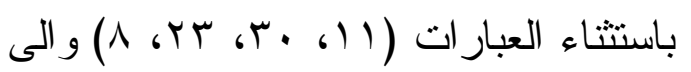

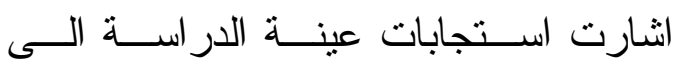
تو اجدها بدرجة مرتفعة، حيــث تراوحست

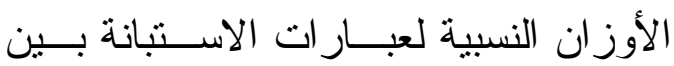

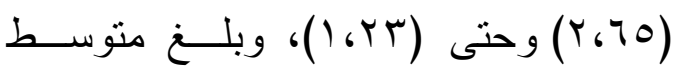

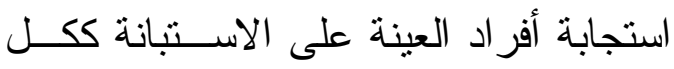
.$(1,10)$ 
تللك العبارة و التي تتص على (يوجد دعــم

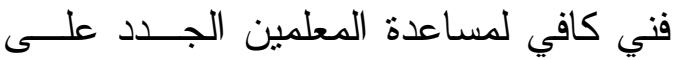
تفهم المنظومة) إلى تو اجدها بدرجة كبيــرة

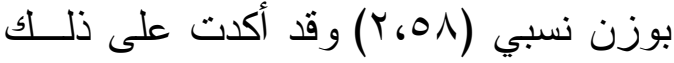
دراســة (Jones, Griff et al 2016) و التى أوضحت إلى أن مدارس المتفــوقين ينبغي أن تقدم خدمات تعليمية ودعميه مسن شأنها تحقيق النطوير المهني لعدد كبير من

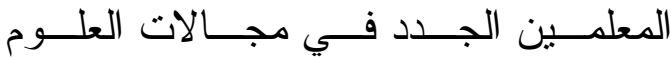
و التكنولوجيا و الهندسة و الرياضـيات بمـــا يخدم احتياجات المعلم ويعزز ممارسـاته، ودراسة (Tyler , et al, 2017) و التـي

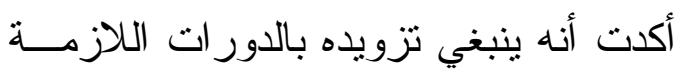

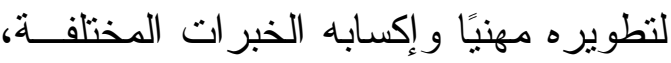
لأن خبرة المربين عامل رئيس في تقدئ دئيم تعليم متميز ، ويختلف ذلك عن نتائج در اسة (Çevik \& Özgünay, 2018) بينت أن المعلمين ليسو امجهـزين بـشكل جيد لتدريس العلوم و التكنولوجيا و الهندســة

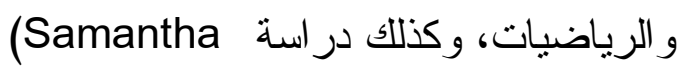

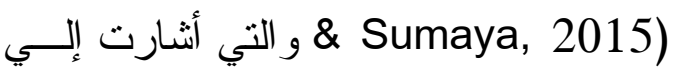
أن ضعف قدرات المعلمـين فــي مجــال

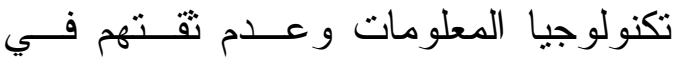

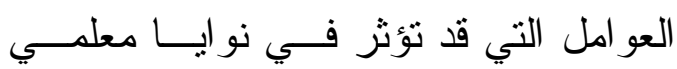

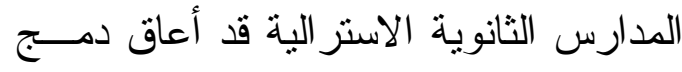

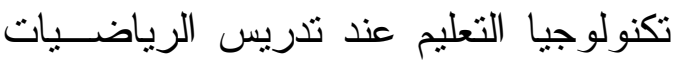
ووجدوا أن المعلمين بحاجة إلي أن يقتنعوا
تأييدهم لتحقق ذلك العامل بدرجة كبيرة وقد

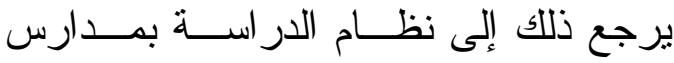

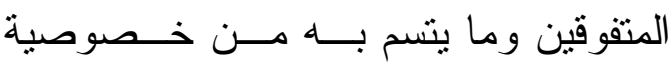
تتطلب إقامة الطلاب بالمدرسة إقامة كاملة ومن ثم فلابد من تو افر حد معقـول مــن بــن العلاقات الانسانية و الاجتماعية الجيدة بــين الطلاب من جانب و إدارة الددرسة ومعلميها

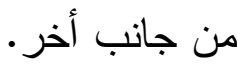
- ويلي ذلك في الترتيب العبارة رقـم (•r) و التي تتص على (توفر إدارة الددرسة بيئة ثرية لاكتثاف الإبداع وتتميته لاي طلابها)

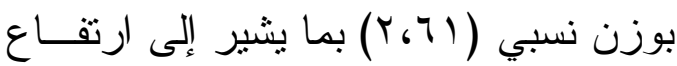

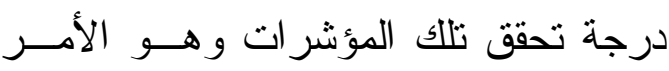

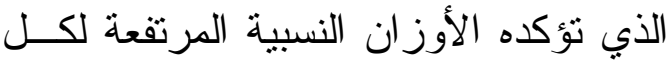
Mullet, ) منهم، وقد أكدت على ذلك در التوزن Dianna R , et al 2018 و التي أنثارت إلى أهمية نو افر بيئة تعليمية فعالة ومتميزة

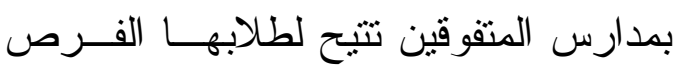

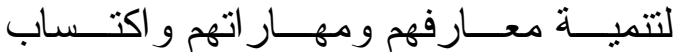

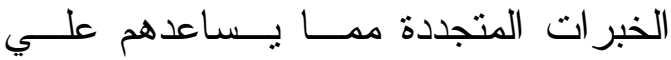

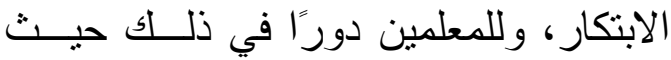
أنثارت دراسة (McDONALD , 2016 ) إلي أن المعلمون يلعبون دورًا محوريًا فــي تعلم الطلاب و إنجاز هم من خلال نوفير بيئة تعلم آمنة وداعمة، و المشاركة في ممارسات تعليمية فعالة - ويأتي في الثرتيب الثالث العبارة رقم (Yr) حيث توضح استجابات عينة الدر اسة علـى في لـي 
إنشاء ثقافة مدرسية حيث يتم التعرف على

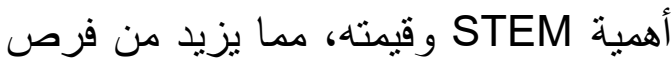

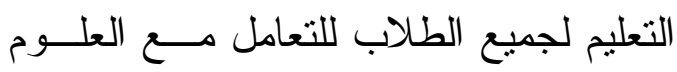
و التكنولوجيا و الهندسة و الرياضيات. - أقل مؤشرات نجاح مدارس المتفوقين تحققاً وفقاً لو اقعها من وجهة نظر عينة الدراســة

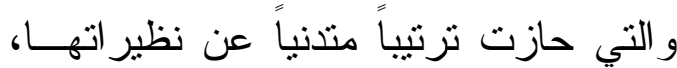
وذللك حسب نرتيب الوزن النسبي و الو اقعة

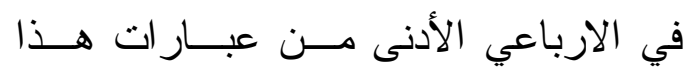

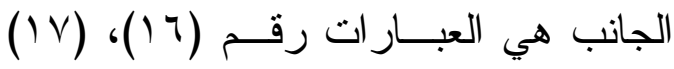
على النترتب، حيث نوضح استجابات عينة الدراسة على العبارة رقم (7 (1) و التي تتص التصابع على (تتاح للك فرص الابتعاث الى الــدول

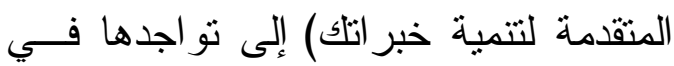

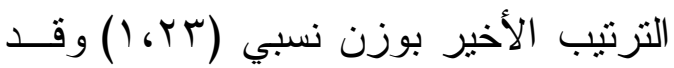
يرجع ذلك إلى أمور تنتعلق بالدعم الدــادي

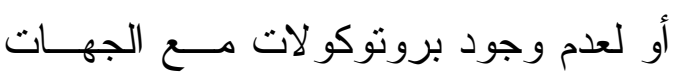
المعنية بالدول ذات التجارب الرائدة بمجال العمل مع الطـــلاب المتفــوقين، ويـسبقهها العبارة رقم (IV) و التي تتص على (يتو افر للطلاب فـرص اســتكمال تعلـيمهم فـي لـي جامعات متخصصة غير نمطيـة) بـــوزن

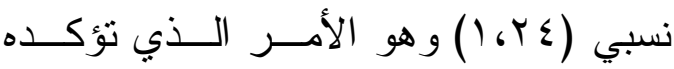
الأوزان النسبية لكل منهه، وربما يكون ذلك الك نابعاً من ندرة الجامعات المختصة بالطلاب

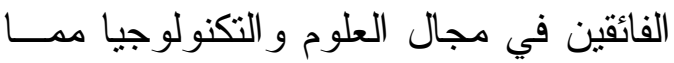

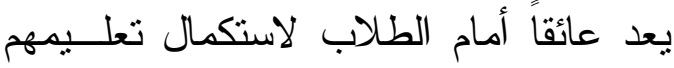
على النحو المطلوب وقد أكدت على أهمية
بأن التكنولوجيا ستزيد من اهتمام الطــلاب وتحفيز هم للتعلم و الابتكار .

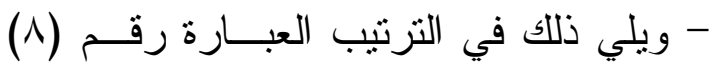
و التي تتص على (الرحلات العلمية كافيــة

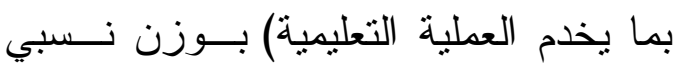

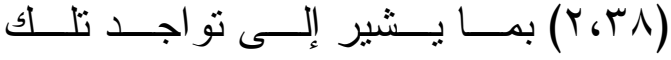
المؤشرات بدرجة مرتفعة، وقد أكدت على

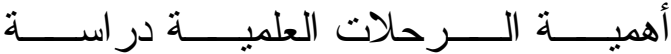
(Banerjee, Pallavi Amitava 2017) و التى أظهرت نتائجها أهمية أنشطة الإثراء و التحسين بمدارس (STEM) كــالرحلات إلى المختبر ات ومر اكز التعليم العالي وذلك بغرض تحسـين فهـ العلوم و التمتع بها علــى المــدى القــصير

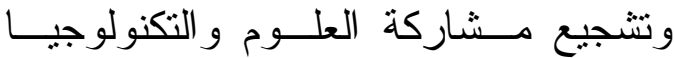
و الهندسة و الرياضيات على الددى الطويل. -ثم جاءت العبارة رقم با و و التي تتص علي (نشر الوعي بمدارس STEM لدى طلاب

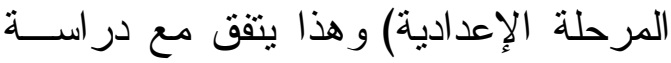
وفيــ (Sumen \& Calisici, 2016 ) يوصى الباحثان بتـــريب المعلمـين قبــلـ الخدمة حول تتجيع طلابهم على الاهتمــام

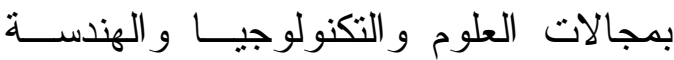

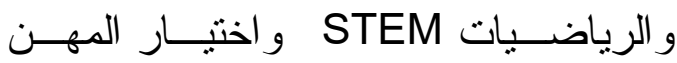
المرتبطة بذلك

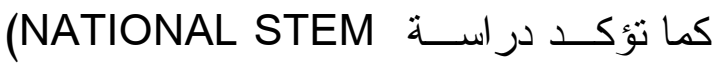
$\mathrm{SCHOOL}$ EDUCATION STRATEGY, 2015) 
دورات تدرييية أثناء الخدمة للتظلب علـى أوجه القصور التي يعانيها الددرسون بشأن

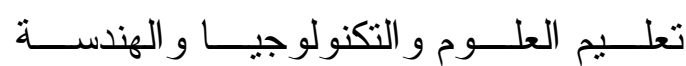

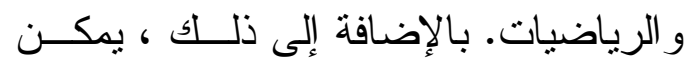

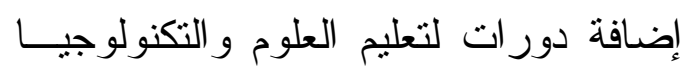
و الهندسة و الرياضيات داخل كليات التربية، كما دراســة ) Han, Sunyoung et al, 2015) علي تقديم أنشطة التطوير المهنـي للمعلمين بشكل منتظم، وفي نفس الـسياق أكـدت دراســة NATIONAL STEM $\mathrm{SCHOOL}$ EDUCATION

STRATEGY, 2015) المعلم وجودة تعلــيم STEM لأن التعلـيم رئل

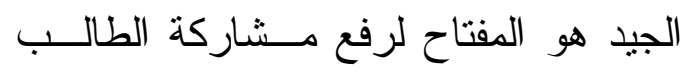

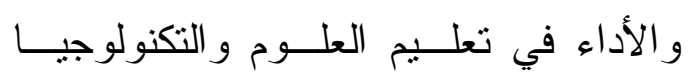

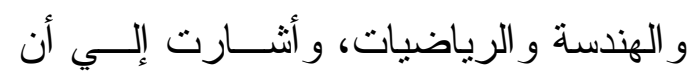

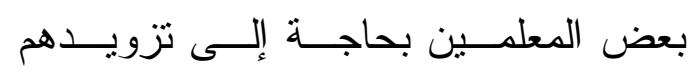

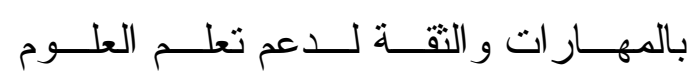
و التكنولوجيا و الهندسة و الرياضيات، ومــن

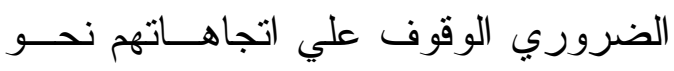
تكنولوجيا المعلومات و الاتــــالات و التــي لوني

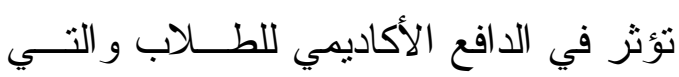

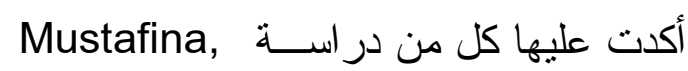
،Farzana, et al, 2018)، (2016) (Kaur, وفي نفس الاتجاه أكدت دراســـة

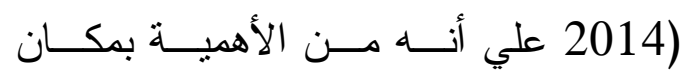
استمر ار تطوير المعلمين وتتميته مهنيًا.
Popa, الجامعات المتخصــصة دراســة Roxana-Alexandra \& Ciascai, (Liliana 2017) ضرورة مو اصلة طلاب مدارس (STEM)

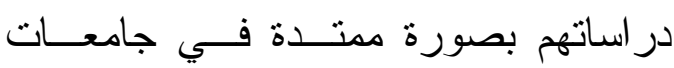
تختص بمجــالات العـــوم و التكنولوجيــا و الهندسة و الرياضيات.

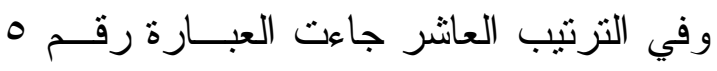
و التي تتص علي (تتاح للك دورات تدريبية للتنمية المهنية المستمرة فى مجال العمـل لفـل

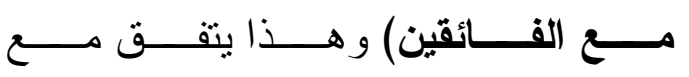
در اســـة(Claudia et al, 2018) و التهـي

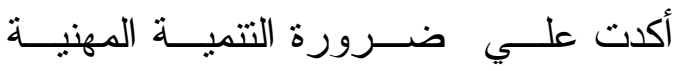

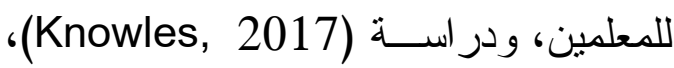
ودر اسة (Sithole et al, 2017) و التـي أكدت علي ضرورة توفير التطوير المهني

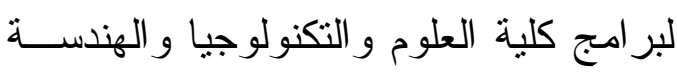
و الرياضيات وتتشمل بعض التدابير الفعالـــة

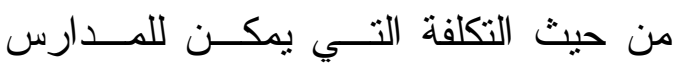

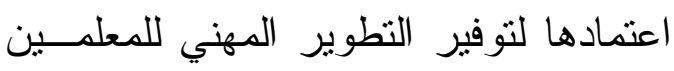

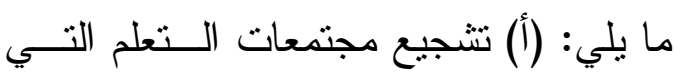

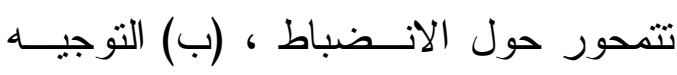

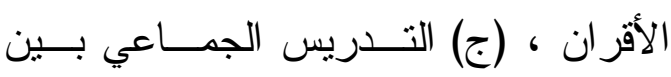
أعضاء هيئة التدريس في التخصصات ذات

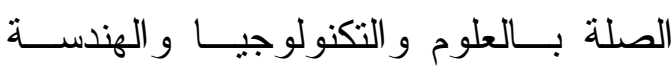

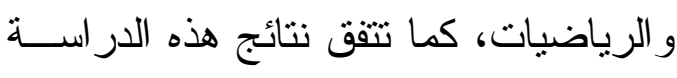
مع توصيات در اسة , Ylldırım \& Turk,

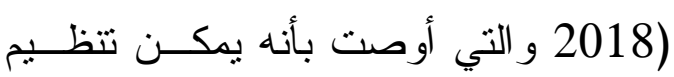




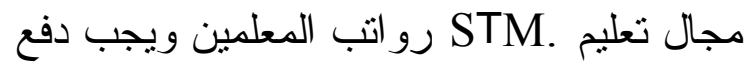
العلاو ات العلمية في الوقت الدحدد للحفاظ على

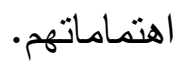
الأمر الذي يشير إلى وجود فروق ذات

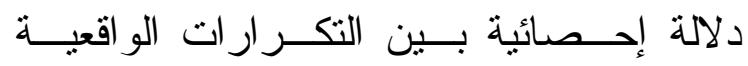

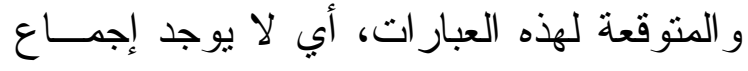

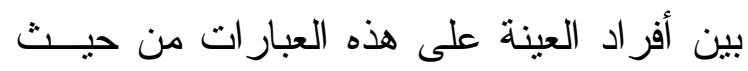
درجة التو اجد، حيث اختلفو ا حول مدى تقــير لقدير

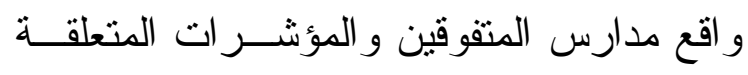

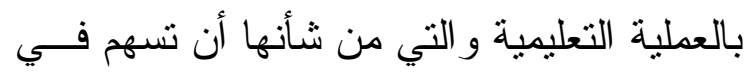

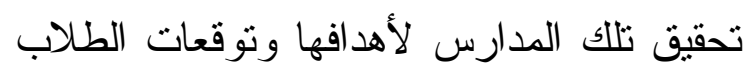

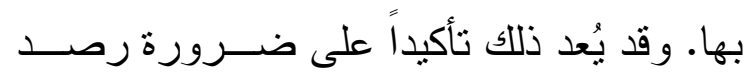

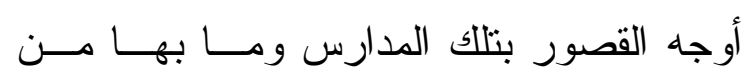
سلبيات لمو اجنها من جانب، وكذلك ضـــرورة

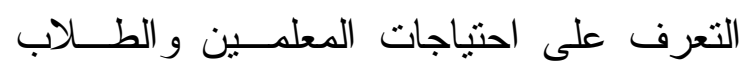
المتفوقين و العمل على تحقيقها من جانب آخر.

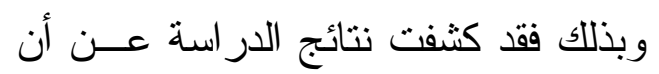

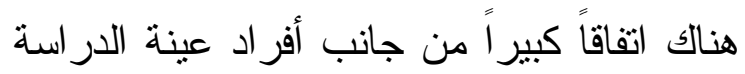

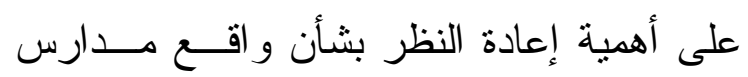

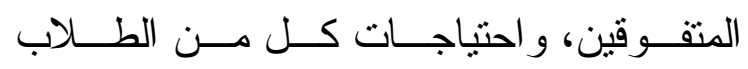

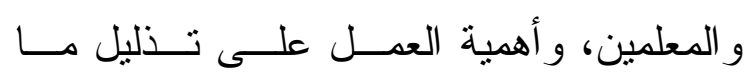
يعترضها من عو ائق ومشكلات ويتفق ذلك مع وعيه

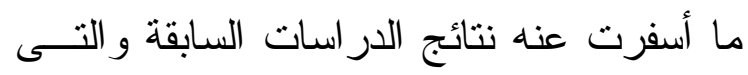

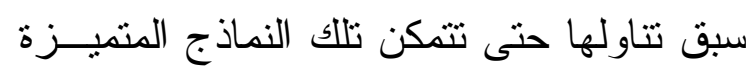

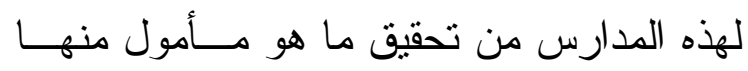

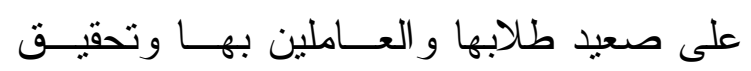
التتمية المنشودة في المجتمع ككل.

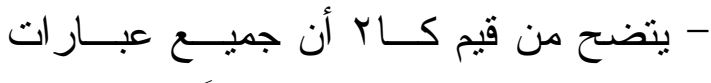

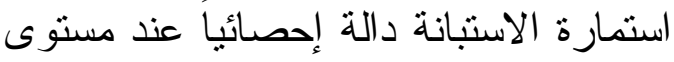

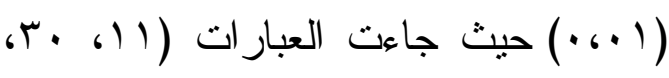

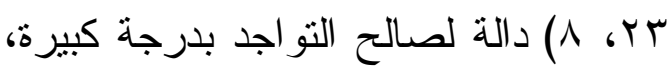

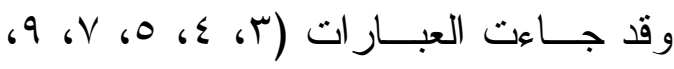

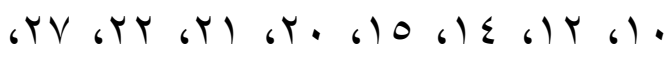

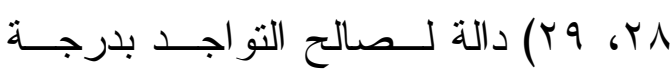

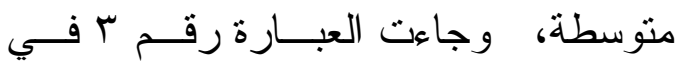

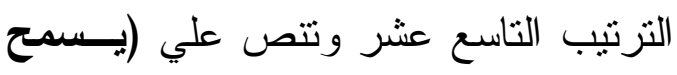

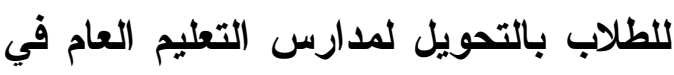

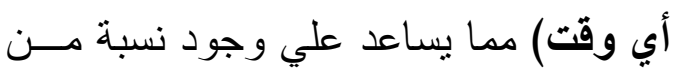
التسرب لطلاب هذه المدارس، وهذا ينقـق مع در اسة (Sithole et al, 2017) و التي لنداب

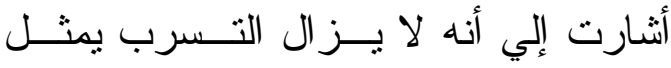

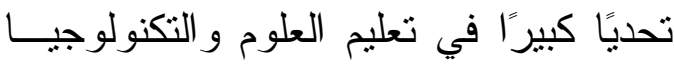

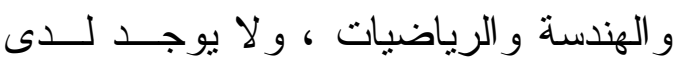

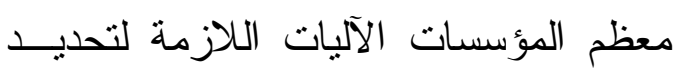
علامات التحذير من التسرب. في حين جاءت العبـار ات (1، Y، T، اب، r) لصالح التو اجد بدرجة ضعيفة، قكانت العبـارة rا و التي تتص علي (الحافز المادي للعـــل

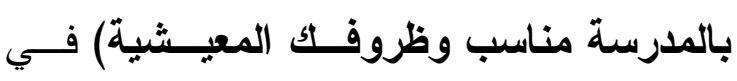

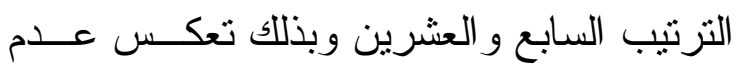
رضا الغالبية العظمي منهم عن الحافز المادي،

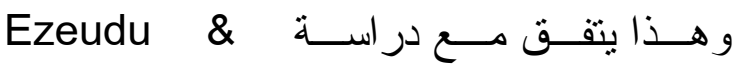

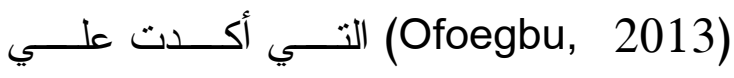
تخصيص الأمو ال الكافية للتعليم خاصـــة فــي 
الميدانية بهذه المدارس لتطبيق أدوات البحــث

قامت الباحثة بسؤ ال الطلاب و المعلمين للوقوف لهن

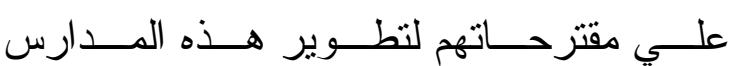
باعتبار هم المسئولين عن هـــا النــــوذج مــن

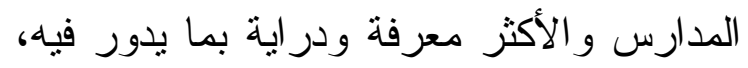
من هنا يأتى المقترح لتطوير مدارس المتفوقين

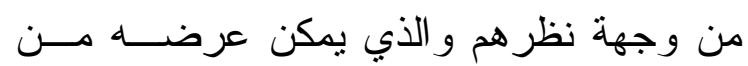
خلال الاطار الفكري للنموذج المقترح لنطوير

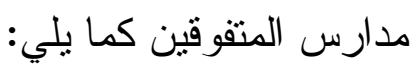

\section{الاطــار الفكـري للنمــوذج الإقـترح لتطـوير مـدارس} المتفوقين - - الاطنار يتكون الاطار الفكري للنموذج المقتــرح

لتطوير مدارس المتقوقين من خمسة عناصـر كما يوضحها الثكل الآتي:
المحور الخامس : مقترح لتطوير مدارس التفـوقين مـن وجهة نظر عينة الدراسة تهدف مدارس المتنـــوقين فـــي العلــوم و التكنولوجيا إلي رعاية المتفوقين وفتح المجال

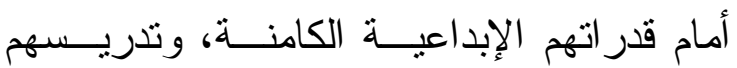

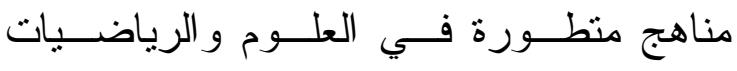

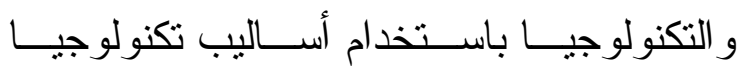
المعلومات لتطوير العطلية التعليمية، و الاهتمـام بالانفتاح علي العالم. و لا يقبل بهذه المدارس إلا المتفوقين من

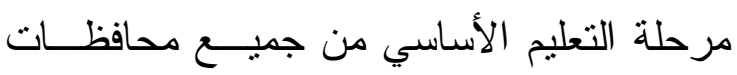

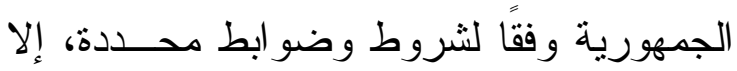
أنه لا بد من المتابعة المستمرة لها للتأكد مـن وفن

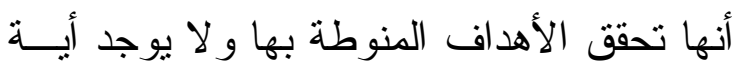
عقبات نو اجه طلابها ومعلميها وفي نفس الوقت

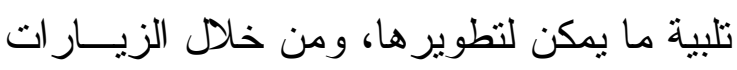
شكل (1) الاطار الفكري للنموذج المقترح لتطوير مدارس المتفوقين

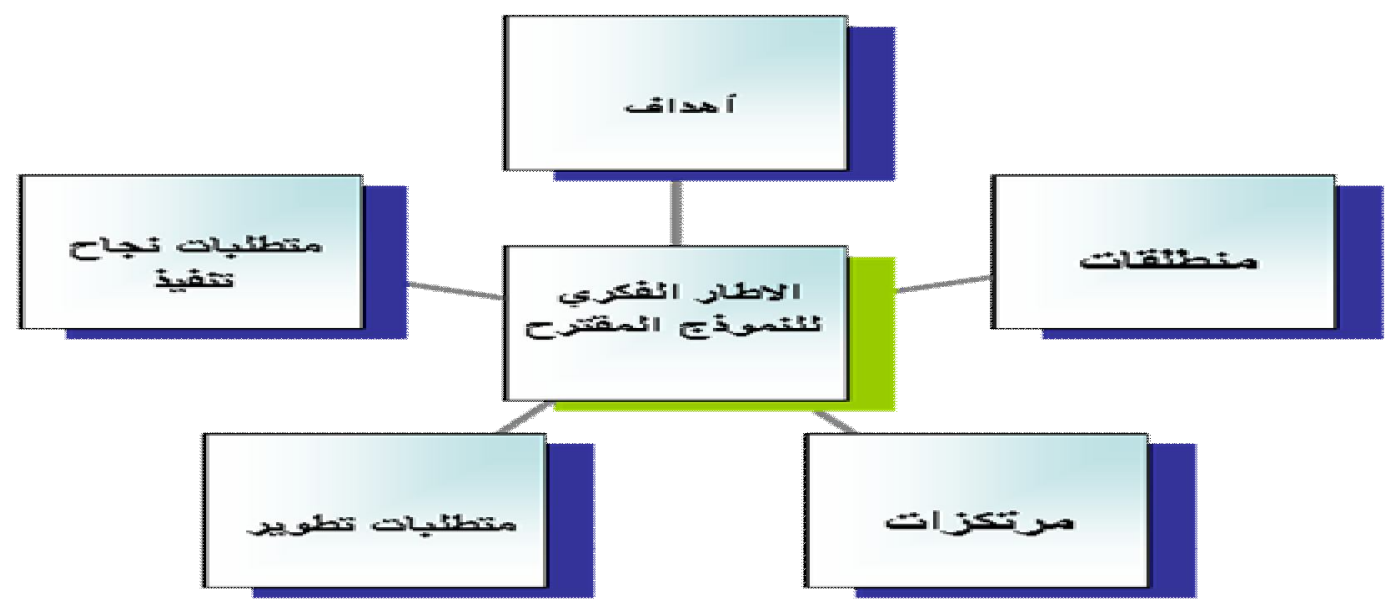

ثانيًا: منطلقات مقتر ح تطوير مدارس المتفوقين

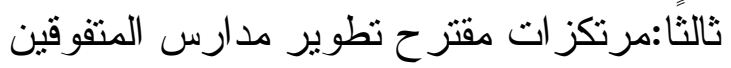
رابعًا: منطلبات تطوير مدارس المتفوقين خامسًا: منطلبات نجاح تنفيذ النموذج المقترح يتضح من شكل (1) أن الاطار الفكري للنموذج المقترح لتطوير مدارس المتفوقين يتكون من خمسة عناصر هي: أولًا: أهداف مقتر ح تطوير مدارس المتفوقين 
- العنصر البشري من طلاب ومعلمين هو المورد الأهم في تحقيق تطوير مدارس لئرس

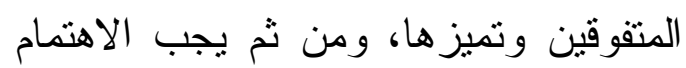

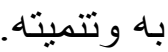
- عقد لقاءات دورية بين مدارس المتفوقين لعرض التجارب و الممارسات المتميزة

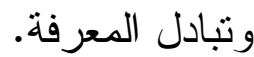
- حاجة المعلمين إلى بناء قدراتهم الإبداعية

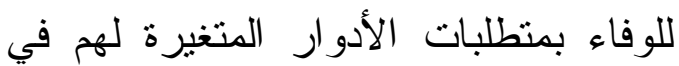
ظل تطور تعليم STEM.

\section{ثالثا: مرتكزات مقترح تطوير مدارس التقوقين} يقوم مقترح تطوير مدارس المتفوقين

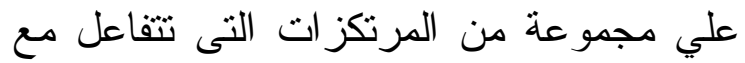
بعضها البعض ومع عوامل البيئة المحيطة بها

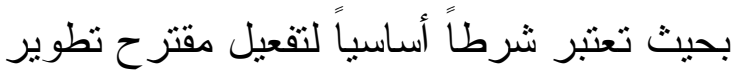
مدارس المتفوقين، وهذه المرنكز ات متعددة إلا

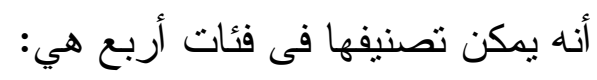
1- مرتكز ات سوسيولوجية: وهى مرتكز ات تعتمد على تفاعل جميع قطاعات المجتمع فى إتمام برنامج هذا التصور، أوبمعنى

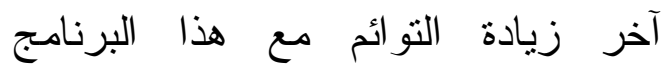

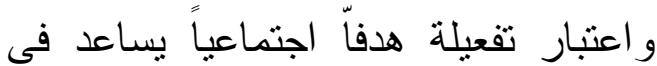

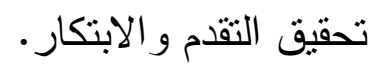
r- مرتكزات أيدولوجية: نقوم على الدعم العقائدى و الدينى لبرنامج التصور المقتر ح حلئح

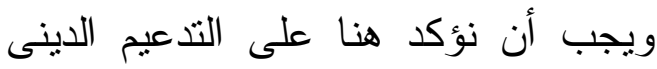

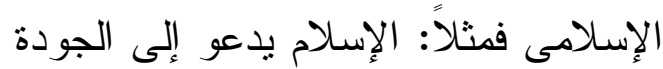

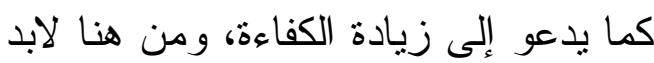

وفيما يلي شرح هذه العناصر بثئ من التفصيل كما يلي: أولًا: أهداف مقتزح تطوير مدارس التفوقين يهرف مقترح تظوير مدارس المتفوقين إلى ملى مارسئ تحقيق ما يلي : - تقديم أفكار وتوجهات جديدة تسهم في الارتقاء بمدارس المتفوقين • - عرض بعض التنتريعات لتساعد وزارة التربية و التعليم على ضبط سبر العمل بمدارس المتفوقين. - تحقيق آمال المجتمع المصري في التو اصل

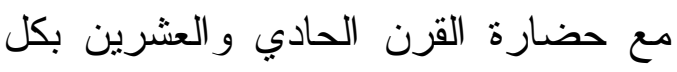
خصائصها العلمية و الاقتصادية و التقنية من خلال رعاية أبناءه المتقوقين. - إبرازدور المشاركة المجتمعية في تطوير

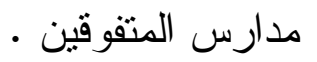
- تحقيق الرضا لدي المعلمين و الطلاب عن المدرسة بتحسين العطلية التعليمية .

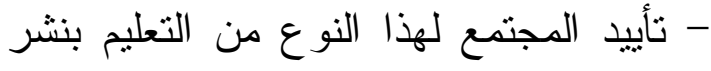
نقافة مدرسة STEM بين جميع طو ائفه. - تدريب المعلمين أثناء الخدمة لتحقيق التتمية المهنية المستمرة لهم. ثانيًا: منطلقات مقترح تطوير مدارس التقفوقين ينطلق مقترح تطوير مدارس المتفوقين من مجمو عة من المنطلقات لعل من أبرزها: - نتائج الإطار الميداني للار اسنة.

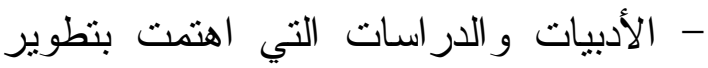

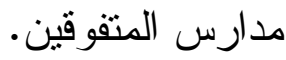


يمكن استخدامها فى دعم واتخاذ القرار

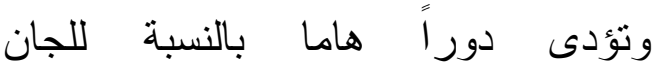

$$
\text { الإسنشارية. }
$$

رابعًا: متطلبات تطوير مدارس المتفوقين هناك مجموعة من المتطلبات لتطوير مدارس المتفوقين في ضوء آراء الطلاب و المعلمين يمكن نوضيحها من خلال الثكل

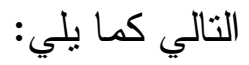

أن تتضافر العوامل الأيدولوجية لتدعيم فكرة خصوصية المنهج و عالمية التنافس r- مرتكزات تكنولوجية: يحتاج التصور المقترح إلى أن تتو افر له قاعدة تكنولوجية

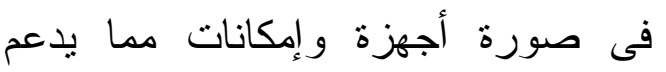
الثفافية و المساعلة ويزيد من الثر اكة الإجنماعية . ع- مرتكزات معلوماتية: ويحتاج التصور المقترح أن تتاح له مادة خام من البيانات

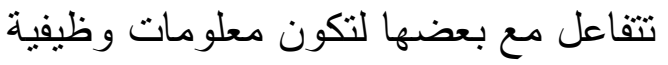

شكل (Y) منطلبات تطوير مدارس المتفوقين

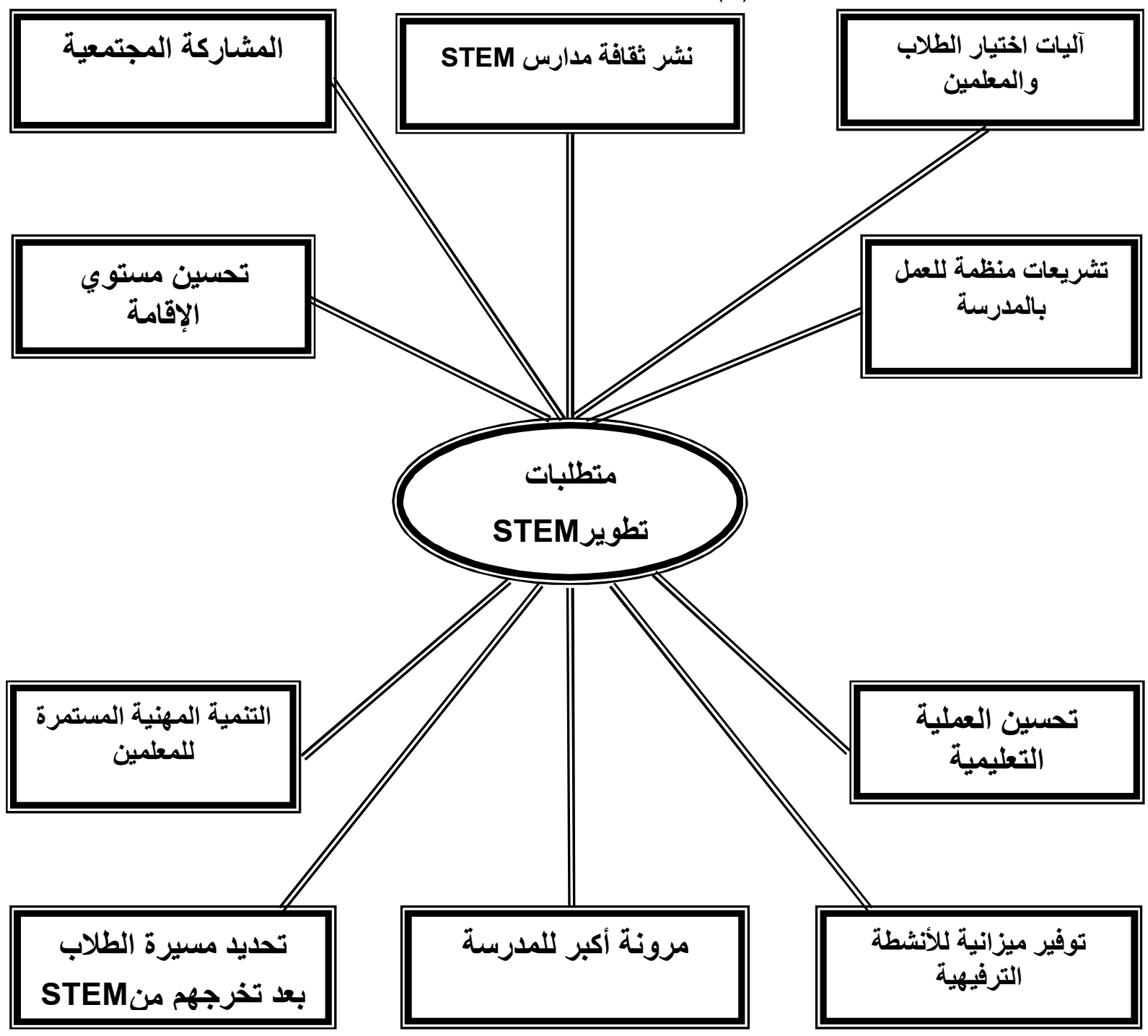


- تخفيض مدة ال Session حتي يسستطيع

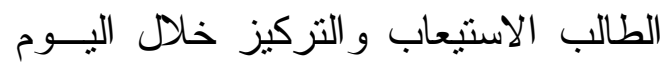
الدر اسي وتتظيم مو اعيد منفصلة لها بحيث لا تتعارض احتياجـات الكابـستون مـن اعند

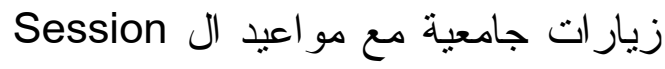

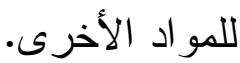
- تعديل ساعات اليوم الدر اسي بمعني تأخير

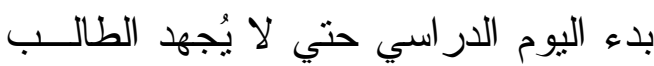

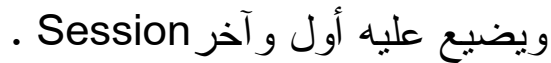
- إلغاء نظام غياب ال Session بغياب يوم

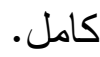
- إعطاء الطلاب حرية الاختيار في الــتعلم

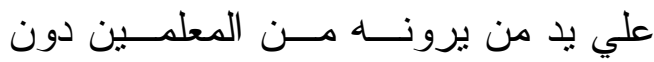
إجبار .

- إعادة النظر في الغياب و إعطائه درجـات

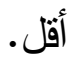

- وضع آلية للوقوف علي مشكلات الطلاب وحلها.

- تعديل بعض المناهج ليتلاعم مـــع الفتــرة الزمنية الخاصة بكل فصل دراسي لطلاب الصف الثالث.

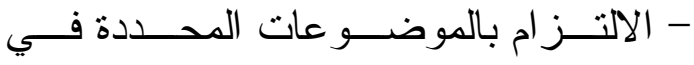
الامتحانات سو اء في الصف الأول و الثاني و الثالث أو في الامتحانات المجمعة للثناث سنوات في الصف الثالث. - وضع قو اعد تمنع الألفاظ الخارجة.

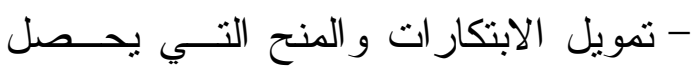
عليها الطلاب.
ويمكن إيضاح منطلبات تطوير مــــارس

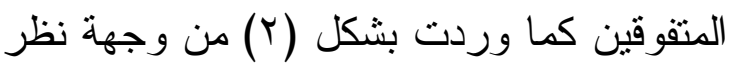
كل من الطلاب و المعلمين فيما يلي:

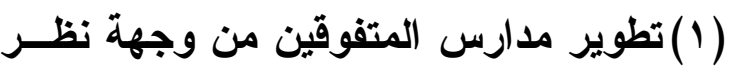
الطلاب يمكن تطوير مــــارس المتفــوقين مـنـ وجهة نظر الطلاب من خلال ما يلي: STEM أ) نثر ثثافة مدرسة - عقد ندوات لطلاب المرحلـــة الإعداديــة الراغبين في الالتحاق بمــدارس STEM للتعريف بها وبأنظمتها.

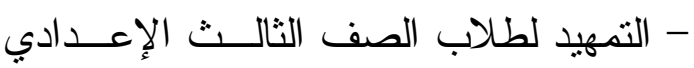
بكورس في منهجهم لتعليم STEM؛ لغـــة ومهار ات. (ب) آليات اختيار الطلاب والمعلمين

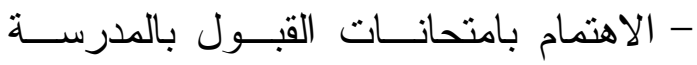

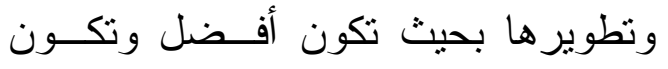

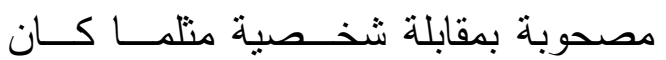

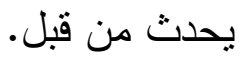
- تعريف الطلاب الجدد بنظام المدرسة.

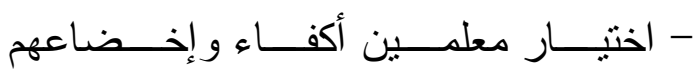
لاختبار ات مختلفة قبــل إلحــاقهم للعهـــل بالمدرسة واختيار المتميزين منهم بحسـن السلوك. (ج) تثريعات منظمة للعمل بالمدرسة

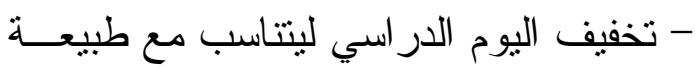

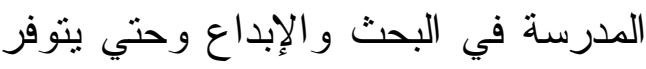
الوقت الكافي لإتاحة التعلم الذاتي. 
- استخدام أسلوب الثنـواب و العقــاب فــي

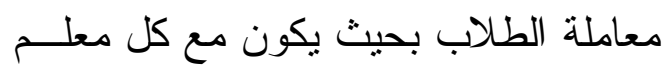
كثف بأسماء الطلاب ويضع فيه علامات مقابل السلوك الصادر من الطالب، ثم يقوم بالثو اب: مكافأة، شهادة تقدير ، كتابة اسمه

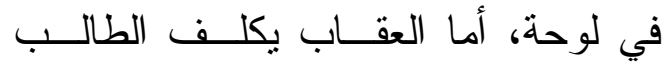
بمسئولية المكتبة يومين بعد انتهاء اليـوم لـوم لئه

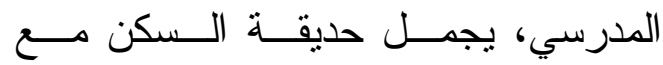

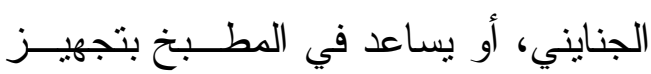
العشاء وتقديمه للطلاب. - تحسين خدمات الإنترنت وزيادة سـر عته

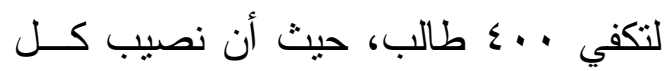
طالب من السرعة r ا كيلو بايت و عندما يصل عدد المستخدمين •0 شخص يكون نصيب الفرد .0 كيلو بايت.

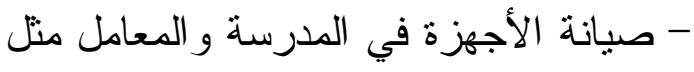

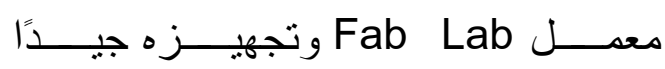
لاستخدامه في المشاريع، وتوفير ميز انيـــة لذلك. - عقد دورات ومعسكر ات صيفية لاكتثاف مو اهب الطلاب المختلفة ومعرفة شغفهم.

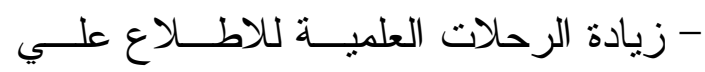
أحدث المستجدات في البحث العلمي.

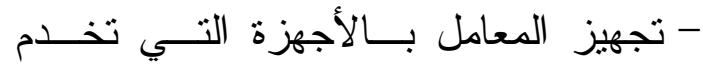

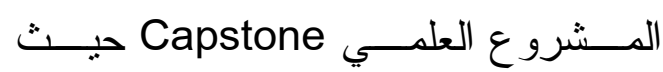
يتطلب توفير العديد من الأجهزة.

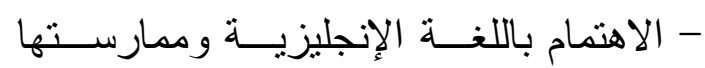
بشكل كامل خلال اليوم الدراسي.
- الاهتمام بالطلاب ذوي الأنشطة الرياضية

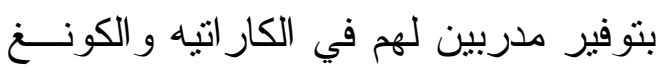

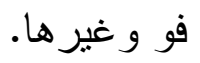
- الالتز ام بوضـــع الأســئلة مــن مفــاهيم مخرجات التعلم Leaning Outcomes.

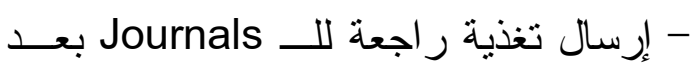
انتهائه لتحسين المستوي. - تقليل درجة المشروع، ويسـتبدل بعمـل لفئل أنشطة ابتكارية متتو عة.

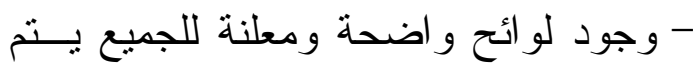
علي أساسها تعامل الإدارة مع الطلاب. - توفير ميز انية خاصة للطلاب المتنيـزين لتنفيذ أفكار هم. (د) تحسين العملية التعليمية - الاهتمام بجودة المشاريع و القدرة الفعليــة علي تتفيذها. - فتح المكتبة ليبًا حتي يمكن الاستفادة منهـــا

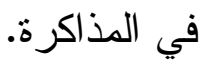
- الاهتمام بالمستوي العلمي للطالب ومتابعته عن طريق المعلمـين وتقــديم المـسـاعدة اللازمة لهم. - الاستعانة بالمو هو بين في أب مجال التقــديم حسص ودور ات لاصــفية بعــــ دوام المدرسة للمهتمين بأي مجال. - تثكيل فريق من الطلاب لكل مادة در اسية

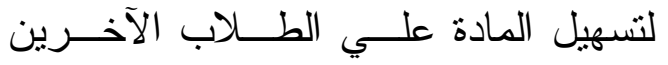
وتحبييهم فيها عن طريق أساليب ممتعــة ومشوقة بالرسوم الإيــضـاحية، بالتمنيــلـ،

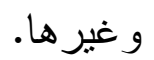


- التفاهم وحسن المعاملـــة بــين المعلمــين

$$
\text { و الطلاب. }
$$

- التيسير في عملية أخذ أذونــات للخــروج

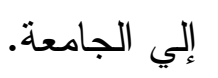

- إعطاء الطلاب قدر أكبر من الحرية فــي

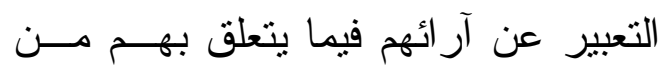

$$
\text { أمور أو قر ار ات خاصة بهم. }
$$

- مشاركة الطلاب في اتخاذ القرار ات.

- الابتعاد عن الروتين في كل شيء من قبل جميع الموجودين بالمدرسة حتــي يكـون

هنالك استفادة حقيقية.

- السماح للطلاب بدخول ال fab lab أثناء

$$
\text { اليوم الدر اسي. }
$$

- عدم التمبيز في المعاملة بين الطلاب. - تقديم محاضر ات من طلاب الصف الثالث لمن هم في الصف الأول و الثاني وزيــادة

$$
\text { التعاون بين الطلاب. }
$$

- رفع الغياب آخر شهر للصف الثالث مـن أجل توفير مناخ أفضل للمذاكرة.

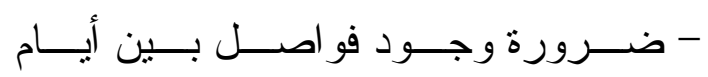

الامتحانات.

(ز) تحديد مسيرة الطلاب بعد تخــرجهم مسن مدرسة STEM

- تعديل تتسيق القبول بالجامعات.

- زيادة حصة طلاب STEM فـي كليــات

القمة.

- الاهتمام بالمنح وتقدير المتميزين فيها.
- تفعيل دور الأخصائي النفسي بما يتتاســب

وطبيعة الموقف وليس مجرد تتظيم الوقت

للقضاء علي الاكتئاب و الحزن دون تقديم

أي مساعدة ملموسة.

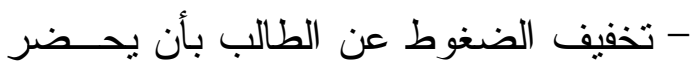

الدروس بالتبادل مــع المعلمــين بحيـــث

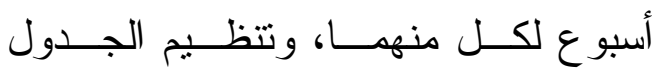

الدر اسي بناءً علي ذلك.

- اتاحة الفرصة للطالب في اجتياز الامتحان

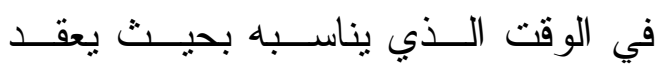

الامتحان أكثر من مرة في أوقات مختلفة.

- تقليل نـسب الجورنــال فــي المـشروع ومر اعاة المساو اة بين الطلاب.

- توفير الفرصة للطالب في تعلم مهــار ات

جديدة وليس تتمية التي يمتلكها فقط.

- تحقيق التعاون بين الطلاب في الأنـشطة الصفية و اللاصفية.

(هـ)توفير ميز انية للأنشطة الترفيهية

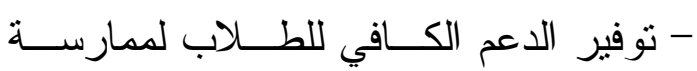
الأنشطة اللاصفية المختلفة وتتويعها. - توفير الأدوات اللازمة للأنشطة المختلفة.

$$
\text { (و) مرونة أكبر للمدرسة }
$$

- تطوير السياسات التــي تـسمح للطالــب هرولـ بحرية التعبير عن رأيــهـهـي فـي المدرســة و المعلمين.

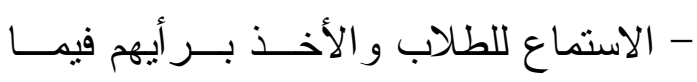
يريحهم وتتفيذ الممكن منه قدر الإمكان. - كسر حدة الروتين في التعامل بين الطلاب

و الإدارة. - - مارة 
- إيجاد آلية لمعالجــة مـشكلات الطــلاب

$$
\text { بالسكن الداخلي. }
$$

- الاهتمام بنظافة المكان باستمر ار، ويكــون العمال أكثر كفاءة في التتظيف.

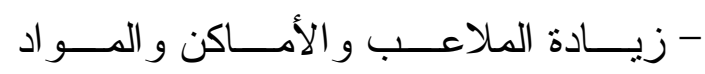

$$
\text { التزفيهية. }
$$

- عمل صندوق شكاوي ومقترحات للطلاب

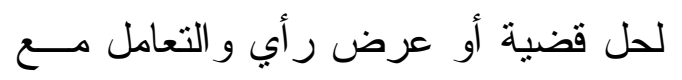
ما فيه كل خميس منتًا.

(ي) المشاركة المجتمعية

- عقد مــؤتمر للآبــاء و الأمهــات و إدارة الدرسة لتطوير المدرسة.

- نوفير ندوات لتوعية الأسر بدور المدرسة لتونة

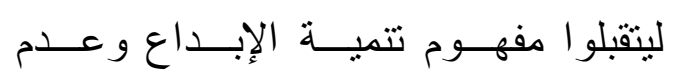

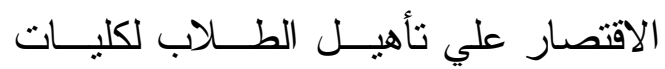
القمة.

- إقامة معارض تلافسية لاختيــار أفــل

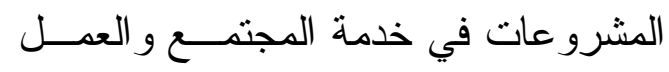

$$
\text { علي تتفيذها. }
$$

- التغطية الإعلامية للمشروعات الطلاييــة

$$
\text { وما بها من ابتكار ات. }
$$

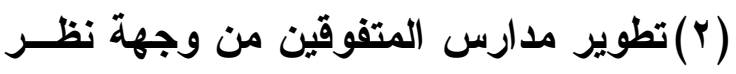

$$
\text { المعلمين }
$$

يمكن تطوير مدارس المتفوقين من وجهة

$$
\text { نظر المعلمين من خلال ما يلي: }
$$

(أ) نشر ثقافة مدرسة STEM

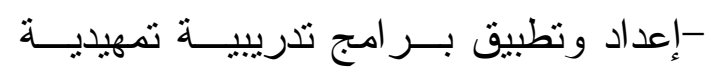

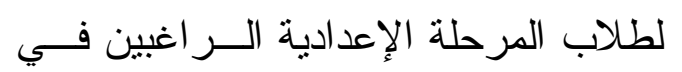

- إنشاء جامعات في مجال STEM أو أفرع

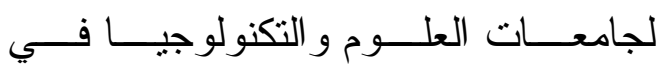
الجامعات المصرية وتسهيل الالتحاق بها. (ح) التنمية المهنية المستمرة للمعلمين - تدريب المعلمون علي اتقان أساليب التعلم المختلفة متل التعلم؛ التعاوني. - تقعيل دورات تدريية في طرق التـدريس

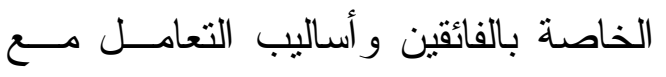

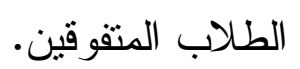

تحسين مستوي الإقامة - حسن اختبار مشرف الإقامة طبقًا لأساليب تربوية سليمة وحثه علي التعامل الجيد مع لإند

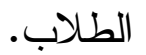
- مبيت مدرسين ليلًا في جميع المو اد. - تعيين طيبب للفترة المسائية.

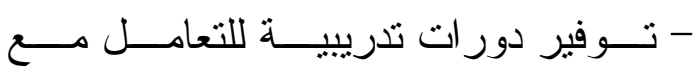
الطو ارئ وطرق حماية النفس وغيرها.

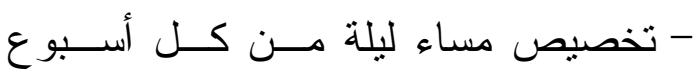
ليمارس الطالب هو اياته. - إقامة يوم ترفيهي كامل fun day. - تحسين مستوي التغذية وزيادة الكمية التي يأخذها كل طالب.

- تحسين وصيانة مبني الإقامة بكل ما فيه.

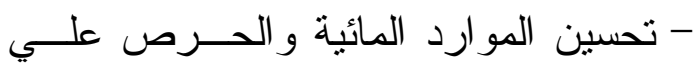
وجودها الدائم. - الرقابة الثديدة علي الطلاب منعًا لحدوث أب سلوكيات غير سليمة كالتدخين. 
- إعادة تقييم الطلاب بعد الالتحــاق بفتــرة و إبعاد من لا يتو افق منهم ونظام المدرسة.

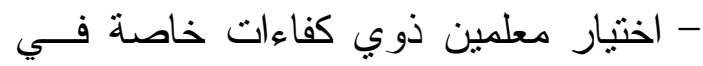

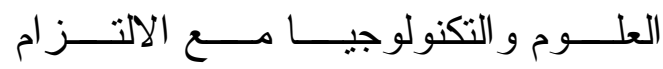
و الاستمر ار في التتمية المهنية المسـتدامة

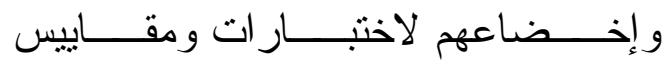

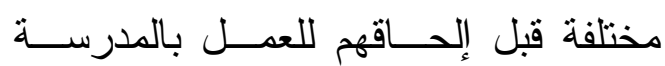
واختيار المتميزين منهم وليس لمجرد سد العجز - فتح المجال للحاصــلين عـــي ماجـسنير ودكتور اه من خارج الوز ارة. (ج) تشريعات منظمة للعمل بالمدرسة - الاهتمام بالبحث العلمي ليكون الأساس في تحــسين مـسـتوي الأداء فــي منظومــــة

\section{.STEM}

- وضع لائحة للانضباط المدرسي بخــلاف

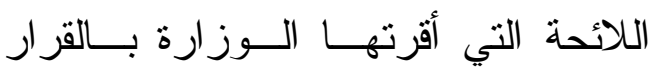
الـــوز اري rیv للمـــدارس العاديـــة لأن STEM حاجة ماسة لقو اعد ثتعامل مع المستجدات تحدد الصلاحيات و أسس معاقبة الطــلاب المخالفين و إطلاع الطلاب عليها وتوقيعهم إقرار بعدم تزك المدرسة إلا في الحالات المنصوص عليها في اللائحة المنشودة. - وضع آلية للوقوف علي مشكلات الطلاب و المعلمين و العمل علي معالجتها.

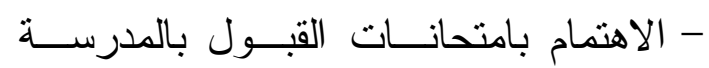
وتطوير ها.
الالتحاق بمدارس STEM للتعريف بهــا وبأنظمتها وتتمية مهار اتهم حولها. -التمهيد لطلاب الصف الثالــث الإعـــدادي بكورس في منهجهم لتعليم STEM؛ لغـــة

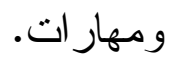

(ب)آليات اختيار الطلاب والمعلمين - إعادة النظر في إجر اءات اختيار الطــلاب الجدد بإضـافة مجمو عة اختبار ات لقيــاس مدي الاســتعداد النفـسي والاجتمـــاعي و السلوكي و الأخلاقي لانـــضمام الطالــب لمدرسة داخلية ومعرفة مدي قدرته علـي تحمل الضغوط حتي لا يصاب بانهيار ات نفسية. - اختيار الطلاب بناءً علي معـايير دقية اعتمادًا علي قدر اتهم العقليـــة ومهـــار اتهم الفكرية. - فتح آفاق لالتحاق الطلاب الموهوبين الذين

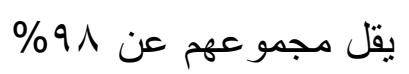
- عمل مقابلة شخصية للطلاب قبل قبــولهم بالمدرســـة لتعــريفهم بنظـــام المدرســـة ومعرفة قدرتهم علي التو افق و التكيف مع نظام المدرسة. - تغيير اختبار ات القبول باســتمر ار ومــن مجمو عة لأخري في نفس العام حتـي لا تتسرب ويلتحق بالمدرسة ذوي الكفــاءات المنخفضة - عمل برنــامج تــــيلي للطــلاب لمـــدة أسبوعين يحضره طلاب الصفوف السابقة ليكونو ا داعم للطلاب الجدد. 
التحكيم، مع بث مباشر لمشاريع الطــلاب

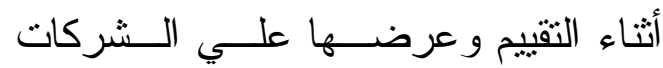
و المصانع لتتفيذها.

- وضع برنامج زمني دقيق للمو اد العلميـــة

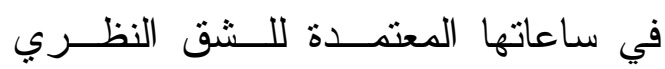

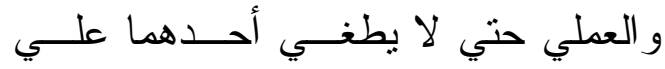

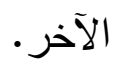

- تحديد أجز اء من المر اجع العلمية للتنريس

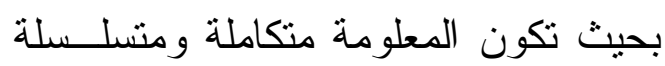
في الموضوع الواحد في نـــواتج الــتـلم

\section{.Leaning Outcomes}

- تعديل نظـــام تقيـيم الطــلاب الخــاص بالمشروع بحيث تكون أســئلة Journals

- تقليل درجة المشروع، ويستبندل بعهـل أنشطة ابتكارية خاصة بكل مادة علي حدة لهن

$$
\text { توضح مدي استيعاب الطلاب لها. }
$$

- تتويع أساليب النقويم في الاختبار ات بـئين

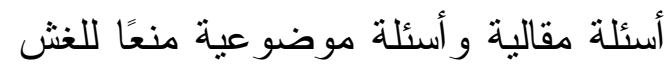

$$
\text { و الاختيار العشو ائي للإجابات. }
$$

- وجود لو ائح منظمة لنسيير العمل و اضحة

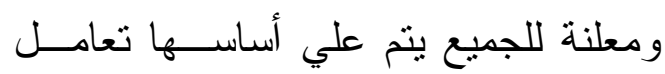

$$
\text { الإدارة مع المعلمين و الطلاب. }
$$

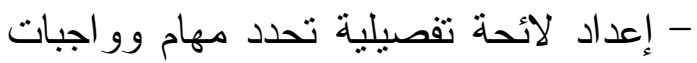
وحقوق و أجاز ات و انتــدابات وتــدريبات

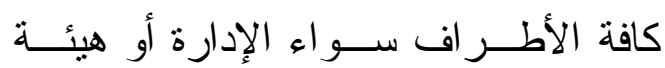

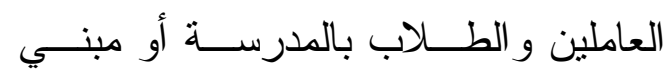
الإقامة، أو شركة الخدمات وطريقة تقيـيم
- عدم قبول طلاب جدد بعد الــشروع فـي

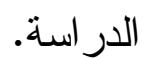
- إلغاء فكرة تحويل الطلاب مــن مــدارس

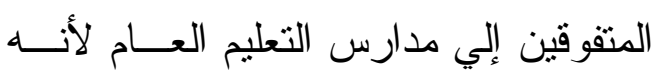

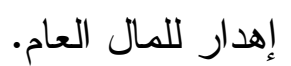
- تخفيف اليوم الدر اسي ليتناسب مع طبيعــة

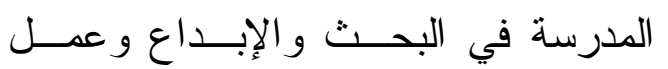
المشرو عات ولتقليل الإرهاق و الملل. - وضع نصاب قانوني لجـدول الحـصص الإنه

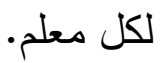
- تخفيض مدة ال Session حتي يستسنيع

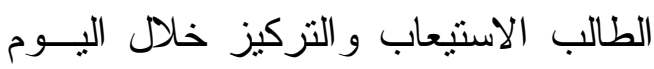
الدر اسي وتتظيم مو اعيد منفصلة لها بحيث لا تتعارض احتياجــات الكابـستون مـن زيار ات جامعية مع مو اعيد ال Session للمو اد الأخرى. زيار جات

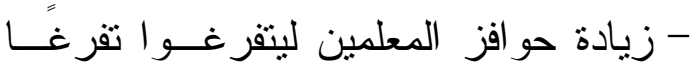
كاملًا للنهوض بالعمل داخل المدرسة. - تعديل بعض المناهج ليتلاءم مـــع الفتــرة الزمنية الخاصة بكل فصل در اسي.

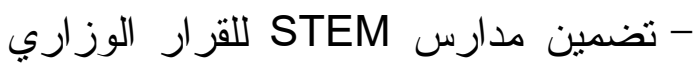

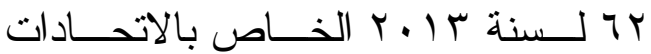

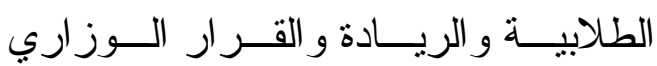
الخاص بمجلس الأمناء.

- توجيه مشرو عات خاصة بكل تخـصص بص الاء

$$
\text { علمي (كل مادة). }
$$

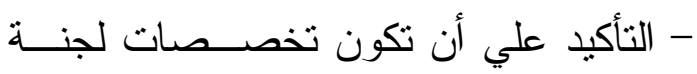

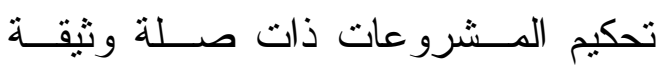
بمجالات البحث و المشروع لضمان جودة 
- تحسين خدمات الإنتزنت وزيادة ســر عته و التعاقد مع شركة توفره \& باعة سوميًا

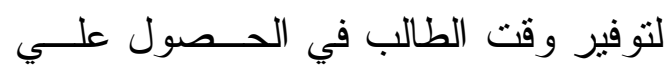
المعلومة.

- وضع قو اعد و اضحة لاستخدام الطــلاب الأجهزة في المدرســـة وتجــريم إتلافهــا وتجريم الاستخدام غيــر الآمــن لـشـبكة الإنترنت.

- ربط مسـدارس STEM ببنـــك المعرفــة و إعطاء الطلاب و المعلمين صلاحية باحث علي حساب بنك المعرفة. - عمل شبكة الكترونية محلية لربط الأقسام بعضها البعض. - توفير مكتبة الكترونية بالمدرسة و الفندق.

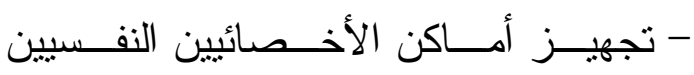
و الاجتماعبين مجهزة بالأدوات و المقاييس اللازمة للتعامل مع الحالات المختلفة. - إنشـاء معامل لغات بالمدرســة و اســتكمال البنية التحتية بصورة مسـستمرة كأعطــال الإنتزنت. إن.

- إيجاد ضو ابط لحضور وغياب الطــلاب، ومو اعيد المذاكرة و النوم.

- تكثيف التهـدريبات للطــلاب و المعلمــين بالتعاون مـــع الجامعـــة لتـــوفير دور ات تدريبية لهم.

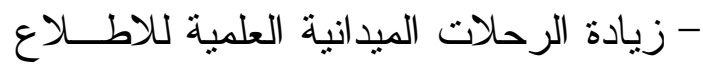
علي أحدث المستجدات في البحث العلمي. - دعم الطلاب بالتو اصل مع المر اكز البحثية

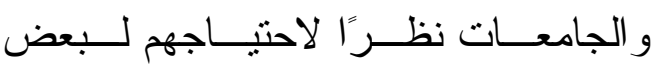

وضع لامحة للاضضباط المدرسي.

- الاستفادة من خبــرات الــدول المتقدمـــة لتطوير المنظومة باستمر ار . - إعطاء المزيد من البر امج الحديثــة مثتـل

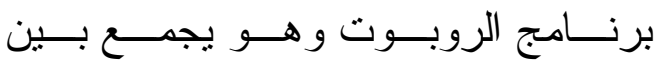
الرياضيات و الكمبيوتز وتوظيف لجميـع الدو ال التي درسها الطالب في المـشكلات الحياتية وتكون ضمن الجدول المدرسـي، برنامج كورت لتتمية مهار ات التقكير لدي الطلاب منل اختيار البدائل و اتخاذ القــرار المناسب. - إلحاق مدارس المتقوقين بيرنامج الجـــدة و الاعتماد التربوي. (د) تحسين العملية التعليمية - الإشر اف علي المدارس من قبــلـل وزارة البحث العلمي إلي جانب إثـــراف وزارة التربية و التعليم. - عقد بروتوكو لات تعاون مــع الجامعــات الحكومية لمساعدة المدرسة في توفير جيل مبتكر من الطلاب. - زيادة فرص الرحلات العلمية لما تــوفره من معلومات قيمة تخـــدم الطــلاب فـــي مناهجهم و المشرو عات التي يقومون بها. - تتويع اللقــاءات و النـــدو ات مـــع أســـاتذة الجامعة في مختلف التخصصات. - فحص أجهزة الكمبيونز المحمــول قبــل تسليمها للطلاب لأنـــه عــصب العمليــة التعليمية بهذه المدارس. 
- نوفير الأدو ات اللازمة للأنثطة المختلفة - السماح للطلاب بالمشاركة في المسابقات. (و) مرونة ولامركزية أكبر للمدرسة

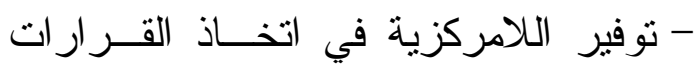
الخاصـــة بــبـض الاحتياجــات داخــل

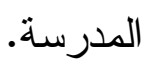

- إعطاء مدير المدرسة صــلاحيات بعدـل تدريبات للمعلمين داخل المدرســة وفــي

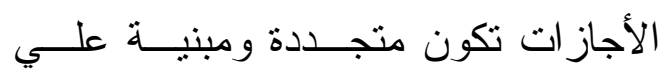
احتياجاتهم الفعلية. - التو اصــل بـين المعلمــين و المـسئولين بالوزارة خاصة في مجال تقييم الطــلاب و الامتحانات. - توفير تبــادل الزيــار ات بـين مــدارس المتقوقين لنقل الخبرات.

- نوفير صندوق مالي خاص بالمدرسة لسد المستلزمات المعلية في حالة الضرورة.

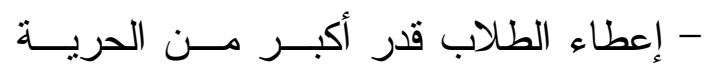

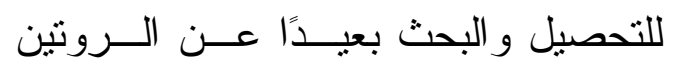
و الغياب و الحضور . - عقد اجنماع دوري شـــري بـين وحسـدة

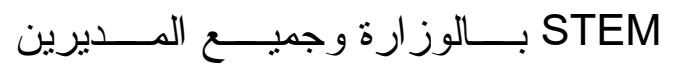
و الوكلاء للوقوف علي مدي سير العهـلـل و الاحتياجات المستمرة. - الحفاظ علي اسنقلالية المــدارس وعـدم تدخل المديريات و الإدارات التعليمية فــي عملها. - مشاركة المعلمين و الطـــلاب فـــي اتخــاذ

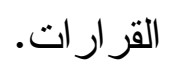

المعامل و الإمكانات الني تخدم الـــشروع العلمي Capstone و التعاون بين الجميـع فيه لتحقيق أهداف الطلاب.

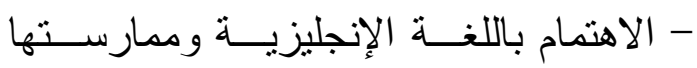
بشكل كامل خلال اليوم الدراسي. - عمل خطة تدريبية سنوية للمعلمين قائهــة

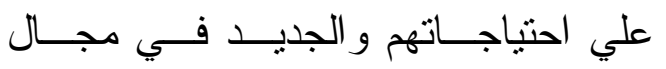
تخصصصهم. - فتح الدجال للعلوم الإنسانية ليكــون لهـــا نصييًا أكبر مما هي عليه. - منح فرص للمعلمين لمو اصلة در اســاتهم العليا لتطوير أنفسهم علميًا. - تفعيل دور الأخصائي الاجتماعي و النفسي

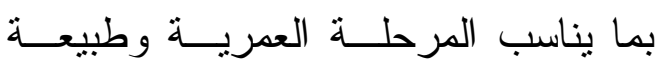
الدر اسة بالمدرسة. - إعطاء المزيد من الاهتـــام للمـشكلات باته البيئية و التحديات التي تو اجه المجتمع في الإهي الاقتصاد، المياة، الفقر، و التلوث.

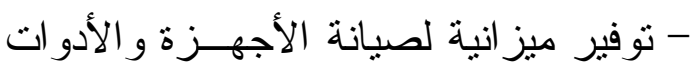

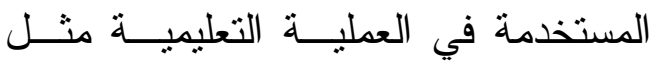

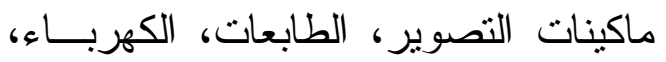
وخدمة الإنترنت. - تتفيذ برامج أو ائل الطلبة في مسابقات بين جميع مدارس المتفوقين. - تحقيق التعاون بين الطلاب في الأنـشطة الصفية و اللاصفية. (هـ) توفير ميزانية للأنشطة الترفيهية

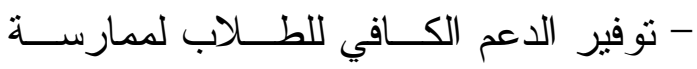
الأنشطة المختلفة وتتويعها. 
- زيادة الدعم الفني لمساعدة المعلمين الجدد

$$
\text { علي تقهم المنظومة. }
$$

- ابتعاث المعلمين و الإداريين إلــي الــدول المتقدمة للتدريب ونقل الخبرات و التطوير

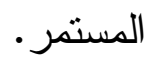

$$
\text { (ط) تحسين مستوي الإقامة }
$$

- حسن اختيار مشرف الإقامة طبقًا لأساليب

$$
\text { تربوية سليمة. }
$$

- تدريب المعلمين علي أحدث الأساليب في سلئ الر عاية الداخلية للطلاب.

- تحسين مستوي التغذية للطلاب. - إيجاد آلية لمعالجــة مــشكلات الطــلاب

$$
\text { بالسكن الداخلي وفي المدرسة. }
$$

- تحــسين خـــدمات الإعاثـــــة للطـــلاب

$$
\text { و المعلمين. }
$$

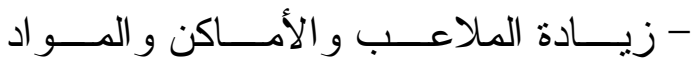

$$
\text { التزفيهية. }
$$

- إنثاء مر اكز للهو ايات و المهار ات المختلفة

$$
\text { بناءً علي استبانات الطلاب }
$$

- عمل مر اكز للتعريف بثقافات المجتمعــات

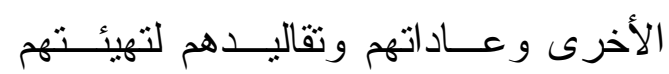

$$
\text { للمشاركة في المنح. }
$$

- جعل الإشر اف و إدارة الفنــادق لــــوزارة التربية و التعليم، و إسنادها إلـــي شــركات أكثر خبرة من الموجودة حاليًا و التي تزكز

$$
\text { فقط علي الربح المادي. }
$$

- فصل إدارة المدرسة عـنـ إدارة الفنــادق ليتقرغ مدير المدرسة لشئون التعليم وحل
(ز) تحديا مسيرة الطلاب بعد تخــرجهم مسن STEM مدرسة

- تعديل تتسيق قبولهم بالجامعات بما يتناسب مع قدر اتهم كعالم باحث صغير فهم كل ما يعلق بالبحث العلمي. - زيادة حصة طلاب STEM فـي كليــات القمة. - زيادة المنح المقدمة لهم مــن الجامعــات الدولية و الخاصة، وجامعة زويل و الجامعة اليابانية في مصر • - إنشاء جامعات في مجال STEM يلتحــق مكتره

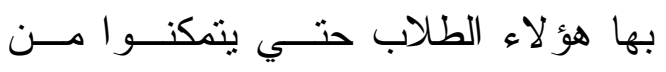
الاستمر ار في التعلــيم الجـــامعي بـــفس النظام الذي اعتادوه في مدارس STEM. - إنشاء أفرع لجامعات العلوم و التكنولوجيــا في الجامعات المصرية الحالية. (ح) التنمية المهنية المستمرة للمعلمين - إعداد قوائم انتظار لمعلمين تــم تــدريبهم مسبقًا للاستعانة بهم في المــدارس حــين الاحتياج إليهم. - تدريب المعلمــون علـي أيــدي أســاتذة جامعيين. - تفعيل دور ات تدريبية في طرق التـدريس الخاصة بالفائقين. - تدريب المعلمون علي استخدام الـسبورة الأكية. - اتقان أساليب التعلم المختلفة مثل الــتعلم؛ التعاوني، التعلم بالاكتشاف، التعلم الذاتي، بأسلوب حل المشكلات. 
- النغطية الإعلاميــة لأنـشطة المدرســـة

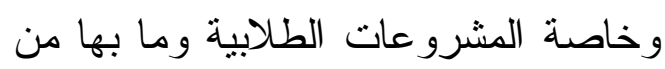

خامسًا: منطلبات نجاح تنفيذ النموذج المقترح

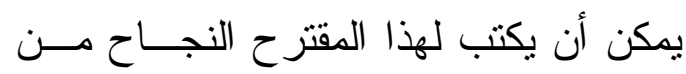

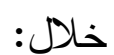

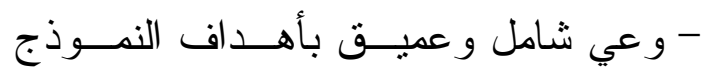

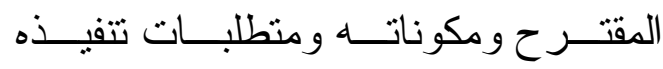

$$
\text { ونجاحه. }
$$

- مبادرة و استعداد من قبــل وز ارة التربيـــة و التعليم لتفعيل النموذج بتلبية متطلباته. - تطوير برنامج إعداد المعلم فـي كليــات التزبية بإعداد معلم لــــارس المتفــوقين

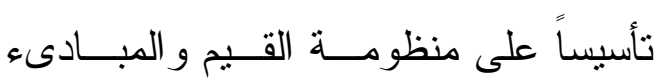

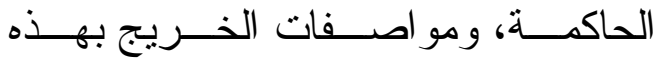

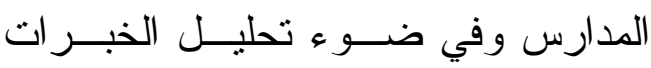
الدولية في مجال تعليم STEM. - نشر ثقافة STEM لتوفير الــدعم الــلازم

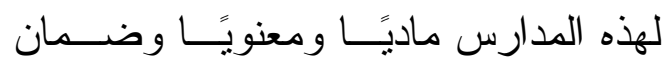

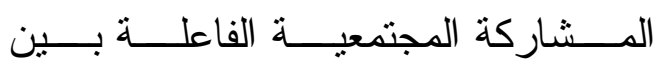
المؤسسات المختلفة. - تطبيق سياسات القبول للطلاب و المعلمين وتطوير ها في ضوء المستجدات العالمية.

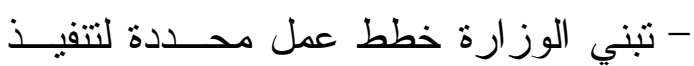
النموذج أو بعض مكوناته.

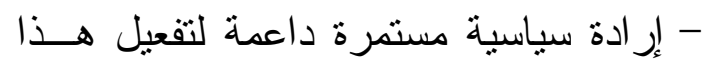
المقترح.
مشكلات الطلاب وما بستجد من مشكلات ناجمة عن العملية التعليمية فقط. - وضع آليات تحكم العلاقة بين إدارة الفندق

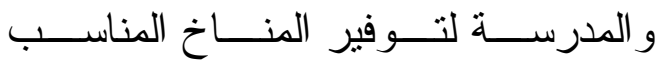
للطلاب. - عمل صندوق شكاوي ومقترحات للطلاب وتخصيص لجنة لفتحسه ومتابعتــهـ كـلـ أسبو ع و التعامل مع ما فيه. (ي) المشاركة المجتمعية

- تفعيل المـشاركة المجتمعيــة مــن قبـــل القيادات في المواقع المختلفة لتوفير الدعم المالي اللازم لهذه المدارس.

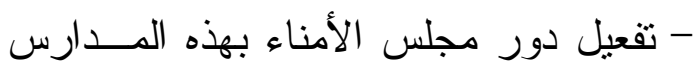
و الأخذ بقر ار اتهم وتوصياتهم. - التو اصل بين الأسرة و المدرســـة لـتابعــة أبنائهم أثناء العملية التعليمية. - نوعية الأسر بنظام المدرسة ليتقبلو ا مفهوم تتمية الإبداع وليس الحصول علي أعلـي لئلي

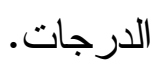
- متابعة سلوكيات الطلاب بالمدرسة و السكن و إيلاغ أولياء الأمور بالمخالفات.

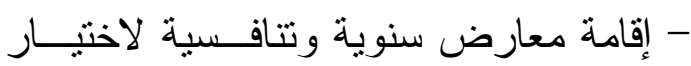

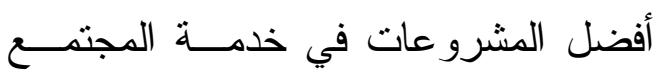
و العمل علي تتفيذها. - تفعيل التواصل بين المدرســة والإعــلام

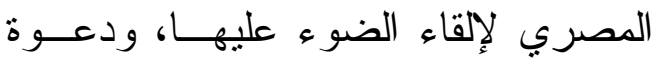
الإعلام رجال الأعمال لنوفير احتياجـات الطعات ودان المدرسة. 
مراجع

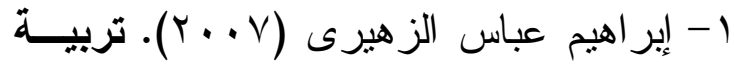

الموهوبين والمعاقين ونظم تعليمهم إطــار فلسفى وخبرات عالمية، ط ب، دار الفكـر

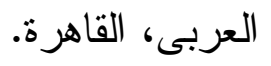

ץ- إبر اهيم مصطفى، و آخرون(د.ت). المعجم المعرة الوسيط، دار الدعوة، القاهرة.

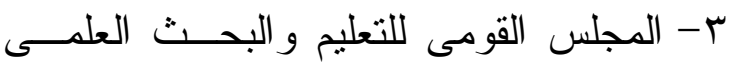

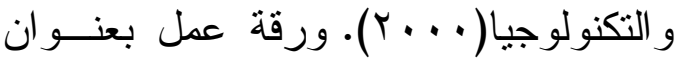

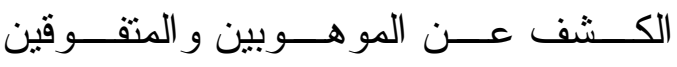
ورعايتهم، المؤتمر القــومى للموهــــين، ورشة العمل التحضيرية(£)، 9 - هـ أبريل

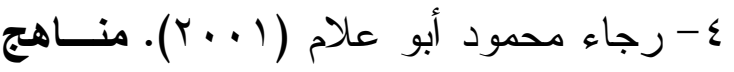

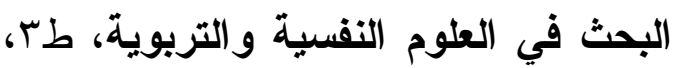
دار النشر للجامعات، القاهرة

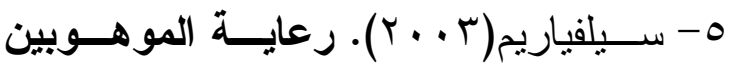
إرشادات للآباء و المعلمين، ترجمة عــادل عبد الله محمد، سلـسلة ذوى الاحتياجــات

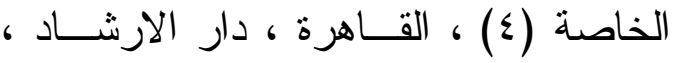
.$\wedge \mathrm{V}$ צ- عبد الباسط محمد شحاته (ع . . ץ). در اسة مقارنة لنظم تربية الطلاب الموهــوبين فـى لـى الو لايات المتحدة الأمريكية و ألمانيا و إمكان

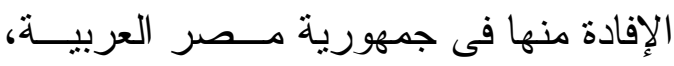

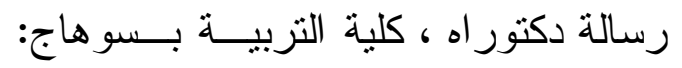

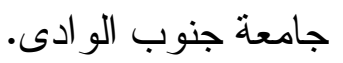

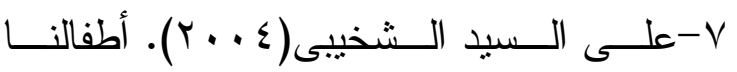
الموهوبون و الأنشطة الددرسية، المــؤتمر العلمى الثانى لمركز رعاية وتتمية الطفولة
- الاهتمام بالتدريب، ويقصد بــهـ أن يقـوم مجمو عة من الخبر اء و المختصين بندريب المعلمين، على فكر جديد يتعلق بالكفاءة أو على تقنية حديثة بهدف إكسابهم المهارات

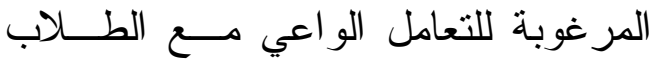

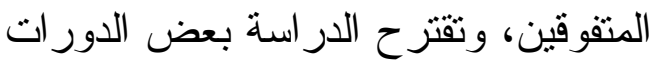
التنريبية ومنها:

Practice- التعلم القائم على الممارسة: based Learning التعلم القائم علـــى البحــث، و التحقــق Inquiry and Research- based Learning Student التعلم المتحور حول الطالب Centered Learning Active Learning التعلم النشط الــتعلم التجريبــى Experimental Learning •التعلم القـائم علـى حـلـ الــشكلات/

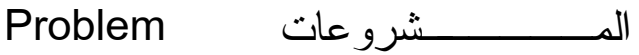
solving/projects -based Learning التعلم القائم على التخصص المعرفـى، Subject \& Interdisciplinarybased Learning

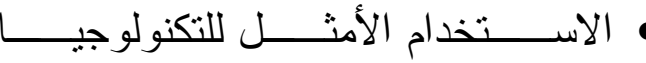
Technology Enhanced Learning Self Assessment الثقييم الذاتى 


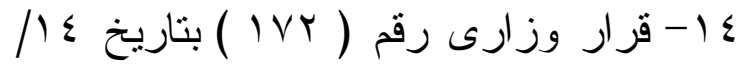

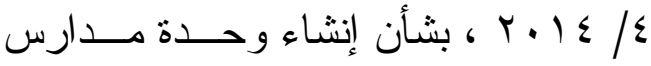

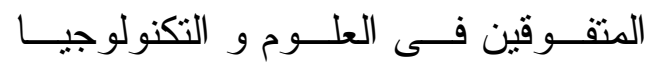
" STEM "

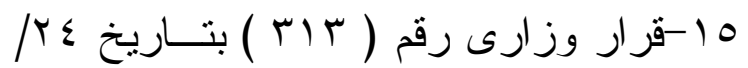

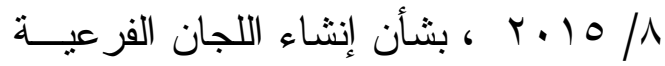
لاعم مدارس المتقوقين الثانوية فى العلوم و التكنولوجيا " STEM " فى محافظــات

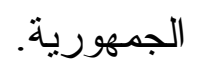

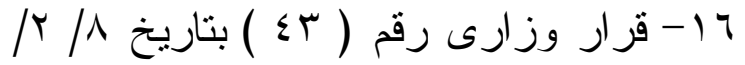

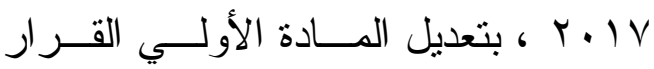

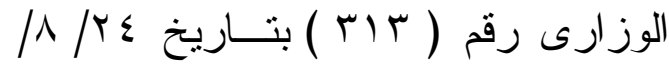

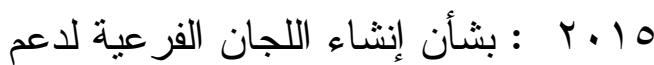

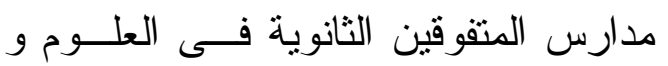
التكنولوجيا " STEM " فـى محافظـــات

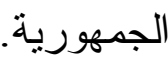

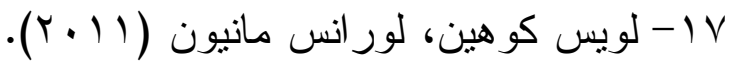

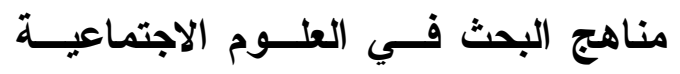

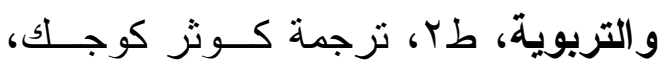

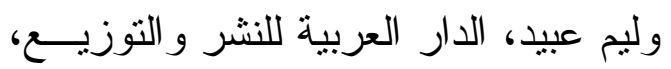
القاهرة. - مانما 1 - مجمع اللغة العربية(99/..... . ب). المعجم

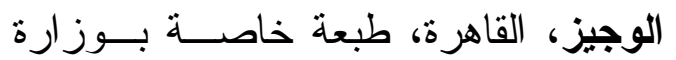
التربية و التعليم

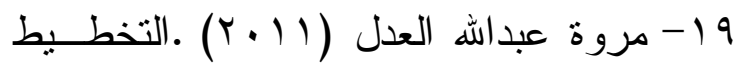

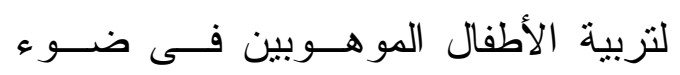
معايير المدرسة الفعالة،رســالة دكتــور اه
"تزبية ذوى الاحتياجات الخاصة فى الوطن

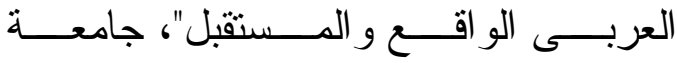

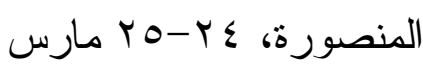

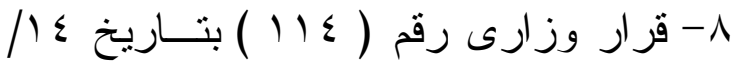

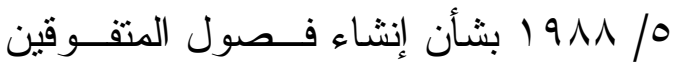
بالمدارس الثانوية العامة

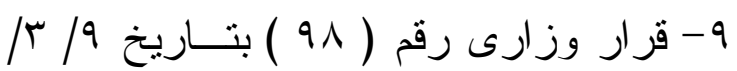
1999 لمدرسة المتفوقين الثانوية للبنين بعين شمس الإس وفصول المتفوقين بالمدارس الثانوية العامة،

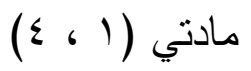
• (1-قرار وزارى رقم (

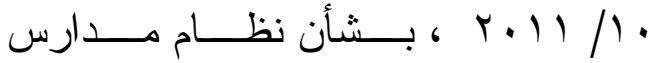
المتفوقين الثانوية فى العلوم و التكنولوجيا.

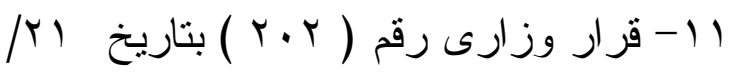

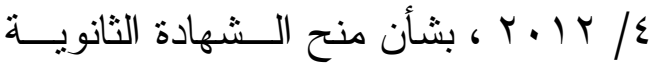
المصرية في العلــوم و التكنولوجيــا مـنـ مدارس المتفوقين الثانوية فــى العلــوم و

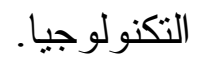

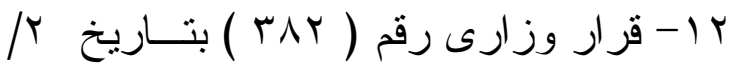

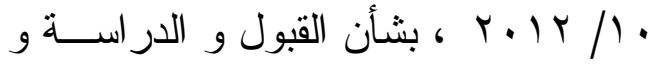

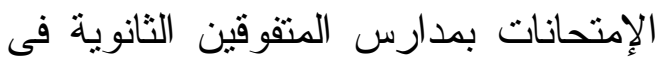
العلوم و التكنولوجيا.

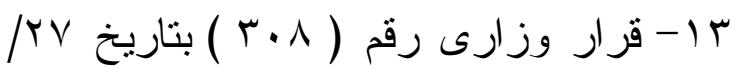

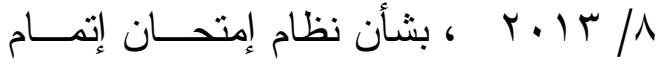
الدراسة الثانوية العامة بمدارس المتفوقين الثانوية فى العلوم و التكنولوجيا. 
in Education and Science, Vol 2, Issue 2, Summer, PP. 322-332. 24-Aslam, Farzana, et al (2018). STEM Outreach Activities: An Approach to Teachers' Professional Development, Journal of Education for Teaching: International Research and Pedagogy, vol.44, no.1, p58-70

25- Alec Sithole et al (2017). Student Attraction, Persistence and Retention in STEM Programs: Successes and Continuing Challenges, Higher Education Studies; Vol. 7, No. 1, pp. 46-59

26-Asghar, Anila, et al (2012). Supporting STEM Education in Secondary Science Contexts, Interdisciplinary Journal of Problem-based Learning, Fall, vol.6, no.2, pp.85-125

27-Bargerhuff، Mary Ellen، and Dunne، James D.، and Renick، Patricia R. "Giving Teachers a Chance: Taking Special Education Teacher Preparation Programs to Rural Communities". Rural Special Education Quarterly. 1st july 2007
،ليــة التربيــة فــر ع دميــاط ،جامعــة المنصورة

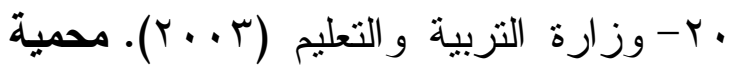
الموهــوبين ، مركــز ســـوز ان مبـــارك الاستكثافى للعلوم و التكنولوجيا ، مطبعــة وز ارة التربية و التعليم ا Y اختــــاصات إدارة اكتــشاف ورعايــة

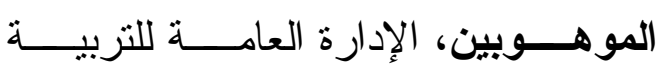

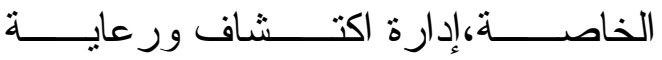
الموهوبين

22- Abd El Aziz, Noha (2014). The Egyptian STEM schools, a national project that is leading Egypt into a strong and vibrant educational and economical reform, Paper presented at the annual meeting of the 57th Annual Conference of the Comparative and International Education Society, Hilton Riverside Hotel, New Orleans, L A

from http://citation.allacademic.c om/meta/p635184_index.html

23- Aliya Mustafina (2016). Teachers' Attitudes toward Technology Integration in a Kazakhstani Secondary School, International Journal of Research 
Science and Technology (IJEMST), Vol. 6, No. 1, pp. 111.

33-Devik, Mustafa \& Dzgünay, Esma (2018). STEM Education through the Perspectives of Secondary Schools Teachers and School Administrators in Turkey, Asian Journal of Education and Training, Vol. 4, No. 2, pp.91-101

34-CHRISTINE V. McDONALD (2016). STEM Education: A review of the contribution of the disciplines of science, technology, engineering and mathematics, Vol. 27, Issue 4, pp. 530-569

35-Cross, T. L. (2010). Social and Emotional Lives of Gifted Students: Understanding and Guiding Their Development. Prufrock Press. ISBN: 978-159363-498-8.

36-DeCoito, Isha (2016). STEM Education in Canada: A Knowledge Synthesis, Canadian Journal of Science, Mathematics and Technology Education, vol.16, no.2, pp.114-128
28-Bekir Yıldırım \& Cumhur Turk (2018). Opinions of secondary school science and mathematics teachers on STEM education, World Journal on Educational Technology: Current Issues, Vol. 10, Issue 1, pp. 52-60

29-Banerjee, Pallavi Amitava (2017). Is Informal Education the Answer to Increasing and Widening Participation in STEM Education? Review of Education, vol.5, no.2, Jun, pp.202-224

30-Berinderjeet Kaur (2014). MATHEMATICS EDUCATION IN SINGAPORE - AN INSIDER'S PERSPECTIVE, IndoMS-JME, Volume 5, No. 1, January, pp. 1-16

31-Billiar, Kristen (2014). Teaching STEM by Design, Advances in Engineering Education, Vol.4, no.1, American Society for Engineering Education ,Win.

32-Capraro, R.M., Barroso, L.R., Nite, S., Rice, D., Lincoln, Y., Young, J., \& Young, J. (2018). Developing a useful and integrative STEM disciplinary language. International Journal of Education in Mathematics, 
41- Forman, Jennifer et al (2015).

National Survey of STEM High

Schools' Curricular and

Instructional Strategies and

Practices, NCSSS Journal, vol.20, no.1, p8-19

42-Ganet Farrall. (2007), Raising your Gifted and Talented Child: the Goys and the Challenges, Gifted and Talented Children Association of South Australia, P.41.

43-Government of South Australia, Department of Education and Child Development. (2012), Policy Statement: Gifted and Talented Children and Students Policy, Pp. 7-8.

44- Guzey, S. Selcen et al (2016). Building up STEM: An Analysis of Teacher-Developed Engineering Design-Based STEM Integration Curricular Materials, Journal of Pre-College Engineering Education Research, vol.6, no.1, Purdue University Press

45-Han, Sunyoung et al (2015). InService Teachers' Implementation and
37-Eramsus (2016).International Diploma for School Teachers in STEM Education / eSTEM, Final Survey Report WP 1

38- Erdogan, Ibrahim \& Ciftci, Ayse (2017). Investigating the Views of Pre-Service Science Teachers on STEM Education Practices, International Journal of Environmental and Science Education, vol.12, no.5, pp.1055-1065

39-F. O. Ezeudu, T. O. Ofoegbu, N. J. (2013). Anyaegbunnam Restructuring STM (Science, Technology, and Mathematics) Education for Entrepreneurship, US-China Education Review A, ISSN 2161-623X, Vol. 3, No. 1, January, pp. 27-32 40-FernZndez-LimZn, Claudia et al (2018). The Role of Non-Formal Contexts in Teacher Education for STEM: The Case of Horno[superscript 3] Science and Technology Interactive Centre, Journal of Education for Teaching: International Research and Pedagogy, vol.44, no.1, pp.71-89 
Education, vol.44, no.3, Jun, pp.461-481

50-Knowles, J. Geoff (2017). Impacts of Professional Development in Integrated STEM Education on Teacher SelfEfficacy, Outcome Expectancy, and STEM Career Awareness, Ph.D. Dissertation, Purdue University

http://www.proquest.com/enUS/products/dissertations/individ uals.shtml

51-Marta De Philippis (2016). STEM Graduates and Secondary School Curriculum: Does Early Exposure to Science Matter?, CEP Discussion Paper No 1443, Centre for Economic Performance, London, August

52-Ministry of Education in Singapore (2012). Gifted Education - Programme:

Development and Growth> http://www.moe.gov.sg/educatio $\mathrm{n} /$ programmes/gifted-educationprogramme/development-andgrowth

53-M Inks, F.J. \& Pflüger, R. (2005). Gifted Education in 21 European Countries: Inventory
Understanding of STEM Project Based Learning, EURASIA Journal of Mathematics, Science

\& Technology Education, vol.11, no.1, pp.63-76 Feb

46- Han, Sunyoung (2017). Korean

Students' Attitudes toward STEM

Project-Based Learning and

Major Selection, Educational Sciences: Theory and Practice, vo1.7 no.2, April, pp.529-548

47- Jones, Griff et al (2016). STEM TIPS: Supporting the Beginning Secondary STEM Teacher, TechTrends: Linking Research and Practice to Improve Learning, vol.60, no.3, May, pp. $272-288$

48- Kasza, Paul \& Slater, Timothy F (2017). A Survey of Best Practices and Key Learning Objectives for Successful Secondary School STEM Academy Settings,

Contemporary Issues in Education Research, vol.10, no. 1, p53-66

49- Kier, Meredith W. et al (2014). The Development of the STEM Career Interest Survey (STEMCIS), Research in Science 
A. Heller\& et al,: International Handbook of Research and Development of Giftedness and Talent. New York : Pergamon, 1993.

58- Paul Kasza \& Timothy F. Slater (2017). A Survey Of Best Practices And Key Learning Objectives For Successful Secondary School STEM Academy Settings,

Contemporary Issues in

Education Research, Vol. 10, No. 1, First Quarter, pp. 53-66 59-Popa, Roxana-Alexandra \& Ciascai, Liliana (2017). Students' Attitude towards STEM Education, Acta Didactica Napocensia, vol.10, no.4, pp.55-62

60-Rakich, S.S. and Tran, V. (2016) A Balanced Approach to Building STEM College and Career Readiness in High School: Combining STEM Intervention and Enrichment Programs, European Journal of STEM Education, Vol. 1, No.3, p. $1-13$ and Perspective. Radboud University Nijmegen.

54- Mullet, Dianna R , et al (2018). Gifted Students' Conceptions of Their High School STEM Education, Journal for the Education of the Gifted, Mar, vol.41, no.1, pp.60-92

55-NATIONAL STEM SCHOOL EDUCATION STRATEGY (2015). A COMPREHENSIVE PLAN FOR SCIENCE, TECHNOLOGY, ENGINEERING AND MATHEMATICS

EDUCATION IN AUSTRALIA, DECEMBER

National STEM school education strategy 2016 - 2026

56-Ozlem Ozçakır Sumen \& Hamza Çalışıcı (2016). Pre-service Teachers' Mind Maps and Opinions on STEM Education Implemented in an Environmental Literacy Course, Kuram Ve Uygulamada Egitim Bilmleri Educational Sciences: Theory \& Practice, 16(2), April, pp. $459-476$

57-Passow, A. Harry : National/ State Polices Regarding Education of the Gifted, In: kurt 
A Meta Analysis, TOJET: The Turkish Online Journal of Educational Technology , January 2018 , volume 17 issue 1, pp. 183-191

66- Stoeger, Heidrun et al (2017). The Learning and Educational Capital of Male and Female Students in STEM Magnet Schools and in Extracurricular STEM Programs: A Study in High-Achiever-Track Secondary Schools in Germany, Journal for the Education of the Gifted, vol.40, no.4, pp.394-416, Dec. 67-Takeuchi, Michio (1997).

Several Controversial Issues on Early Childhood Education and Care in Contemporary Japan , US.Department of Education. 68- Tyler Ames, et al (2017). Wanted For 21st Century Schools: Renaissance STEM Teacher

Preferred, Journal of Technology Education, Vol.28, No.2, Spring, p.p. 19-30

69- Yildirim, Bekir (2016). An Analyses and Meta-Synthesis of Research on STEM Education,
61-Rosalie Primary School. (2011). Gifted and Talented Policy: Working Papers, Rosalie.

62-Roxana-Alexandra Popa \& Liliana Ciascai

(2017). STUDENTS' ATTITUDE TOWARDS STEM EDUCATION, Acta Didactica Napocensia, Vol. 10 , No. 4, pp. 55-62

63-Sharifah Sariah Syed Hassan \& Ahmad Abdullahi Ibrahim (2018). The Art of Teaching Science in Secondary Schools: A Meta Analysis, TOJET: The Turkish Online Journal of Educational Technology , January 2018, volume 17 issue 1, pp. 183-191

64- Samantha Anne Hart \& Sumaya Laher (2015).

Perceived usefulness and culture as predictors of teachers attitudes towards educational technology in South Africa, South African Journal of Education, Volume 35, Number 4, November, pp.1-13 65-Sharifah Sariah Syed Hassan \& Ahmad Abdullahi Ibrahim (2018). The Art of Teaching Science in Secondary Schools: 
Public Dialogue with Pedagogic Praxis, Journal of Education for Teaching: International Research and Pedagogy, vol.44, no.1, pp.90-106

72- Wu, Tien Wu (1993). Programs and Practices for Identifying and Nurturing Giftedness and Talent in Asia, In: Kurt A. Heller et al: International Handbook of Research and Development of Giftedness and Talent. New York: Pergamon
Journal of Education and

Practice, vol.7, no.34, pp.23-33 70-Yildirim, Bekir \& Türk, Cumhur (2018). Opinions of Secondary School Science and Mathematics Teachers on STEM Education, World Journal on Educational Technology: Current Issues, vol.10, no.1, pp.52-60

71-Watermeyer, Richard \& Montgomery, Catherine (2018). Public Dialogue with Science and Development for Teachers of STEM: Linking 